\title{
Het geluid van gisteren : waarom Amsterdam vroeger ook niet stil was
}

Citation for published version (APA):

Jacobs, A. E. G. (2014). Het geluid van gisteren : waarom Amsterdam vroeger ook niet stil was. [, Maastricht University]. Datawyse / Universitaire Pers Maastricht. https://doi.org/10.26481/dis.20140115aj

Document status and date:

Published: 01/01/2014

DOI:

10.26481/dis.20140115aj

Document Version:

Publisher's PDF, also known as Version of record

\section{Please check the document version of this publication:}

- A submitted manuscript is the version of the article upon submission and before peer-review. There can be important differences between the submitted version and the official published version of record.

People interested in the research are advised to contact the author for the final version of the publication, or visit the DOI to the publisher's website.

- The final author version and the galley proof are versions of the publication after peer review.

- The final published version features the final layout of the paper including the volume, issue and page numbers.

Link to publication

\footnotetext{
General rights rights.

- You may freely distribute the URL identifying the publication in the public portal. please follow below link for the End User Agreement:

www.umlib.nl/taverne-license

Take down policy

If you believe that this document breaches copyright please contact us at:

repository@maastrichtuniversity.nl

providing details and we will investigate your claim.
}

Copyright and moral rights for the publications made accessible in the public portal are retained by the authors and/or other copyright owners and it is a condition of accessing publications that users recognise and abide by the legal requirements associated with these

- Users may download and print one copy of any publication from the public portal for the purpose of private study or research.

- You may not further distribute the material or use it for any profit-making activity or commercial gain

If the publication is distributed under the terms of Article $25 \mathrm{fa}$ of the Dutch Copyright Act, indicated by the "Taverne" license above, 


\section{Het geluid van gisteren}

Waarom Amsterdam vroeger ook niet stil was 
(C) Copyright Annelies Jacobs, Maastricht 2014

Omslag: 'Dam zuidzijde, gezien naar Rokin', tekening door Bernard van Vlijmen. Beeldbank Stadsarchief Amsterdam.

Omslag ontwerp: Annelies Jacobs

Drukwerk en layout door: Datawyse Maastricht / Universitaire Pers Maastricht

Dit werk maakt deel uit van het onderzoeksprogramma Soundscapes of the Urban Past: Staged Sound as Mediated Cultural Heritage dat (mede)gefinancierd is door de Nederlandse Organisatie voor Wetenschappelijk Onderzoek (NWO).

Het drukken van dit proefschrift is mede mogelijk gemaakt door een financiële bijdrage van de Nederlandse Onderzoekschool voor Wetenschap, Technologie en Moderne Cultuur (WTMC). 


\title{
Het geluid van gisteren
} Waarom Amsterdam vroeger ook niet stil was

\author{
PROEFSCHRIFT \\ ter verkrijging van de graad van doctor aan de Universiteit Maastricht, \\ op gezag van de Rector Magnificus, Prof dr. L.L.G. Soete \\ volgens het besluit van het College van Decanen, \\ in het openbaar te verdedigen op woensdag 15 januari 2014 om 12.00 uur \\ door
} ANNA ELISABETH GODFRIED JACOBS

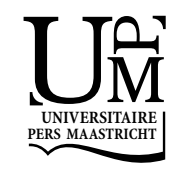




\section{Promotor:}

Prof. dr. K.T. Bijsterveld

\section{Copromotor:}

Prof. dr. A.W. Fickers (Université du Luxembourg)

Beoordelingscommissie:

Prof. dr. ir. W.E. Bijker (voorzitter)

Prof. dr. R.A.M. Aerts (Radboud Universiteit Nijmegen)

Prof. dr. W.J.H. Furnée (Open Universiteit/Universiteit van Amsterdam)

Prof. dr. J.H.W. Kusters

Dr. J.M.C. Wachelder 


\section{Inhoudsopgave}

$\begin{array}{ll}\text { Voorwoord } & 7\end{array}$

Het geluid van gisteren: Introductie $\quad 9$

"Woeling en geraas" 9

$\begin{array}{ll}\text { Centrale vragen } & 11\end{array}$

Geluid onder de loep $\quad 14$

Het geluid van Amsterdam $\quad 15$

De plot van dit boek $\quad 17$

Luisteren naar het verleden: Analytisch raamwerk, methoden en bronnen $\quad 19$

$\begin{array}{ll}\text { Soundscapes } & 19\end{array}$

$\begin{array}{ll}\text { Analytisch raamwerk } & 21\end{array}$

Methoden en bronnen $\quad 28$

Slot: bronnen, genres en discours $\quad 40$

"In een stad als Amsterdam wordt het eigenlijk nooit geheel en al stil":

Stadsgeluid aan het einde van de negentiende eeuw 43

Inleiding 43

"In de straat stijgt ratelend en schaterend het leven eener groote stad naar boven" 44

"Waarom geduld dat er des nachts op de werf wordt gewerkt?" 53

Zingen, luiden, trommelen en oproer kraaien $\quad 58$

Buiten de 'gehoorzone', binnen de tekst: nieuwe betekenissen van geluid 63

$\begin{array}{ll}\text { Conclusie } & 77\end{array}$

"Met schor gehoest van nijdige claxons": Stadsgeluid in het interbellum $\quad 81$

Inleiding $\quad 81$

Geluid en tekst uit het begin van de twintigste eeuw

De ingrediënten van het klanklandschap tijdens het interbellum 86

Politiek van geluid in het interbellum: weerklank van veranderend stadsleven? 112

$\begin{array}{ll}\text { Conclusie } & 122\end{array}$ 
"Een geweldig onweer en rumoer": oorlogsgeluid in de stad

Geluid en betekenis

Waarom Amsterdam vroeger ook niet stil was: Conclusie

Stadsgeluid: 'oor'zaak en discours

Stadsgeluid in de laat negentiende en vroeg twintigste eeuw

Bijlage: Overzicht primaire bronnen

Databanken

Dagboeken 


\section{Voorwoord}

Ik draag dit proefschrift op aan mijn moeder en grootmoeder. De laatste heb ik niet gekend, ze overleed toen mijn moeder - de oudste van haar vier kinderen - zeven jaar was. Mijn moeder heeft vervolgens de lagere school doorlopen en daarna mocht ze als dienstmeisje aan de slag. Of mijn grootmoeder heeft leren lezen en schrijven weet ik niet, maar veel tijd heeft ze er vast niet aan kunnen besteden. Ik ben nog geen dertig jaar na haar overlijden geboren en toch zijn de mogelijkheden die ik heb gekregen lichtjaren verwijderd van de situatie waarin mijn moeder en grootmoeder het moesten zien te rooien. Om die reden wil ik deze dissertatie graag met hen delen. Het besef van de kloof tussen de kansen die zij hadden en die mij geboden zijn, stemt bovendien tot grote dankbaarheid. Niet alleen jegens alle personen die mij ooit hebben gesteund en gestimuleerd, maar ook ten opzichte van de samenleving als geheel die mij de middelen bood om door te gaan met studie en onderzoek.

Dit proefschrift had niet bestaan zonder de financiële ondersteuning van NWO (Nederlandse Organisatie voor Wetenschappelijk Onderzoek) en evenmin zonder de gedreven en gedegen begeleiding van mijn promotor Karin Bijsterveld en copromotor Andreas Fickers, waarvoor ik hen zeer erkentelijk ben. Voor het succesvol doorlopen en voltooien van bepaalde aspecten of onderdelen van het promotieonderzoek ben ik bovendien schatplichtig aan een hele waslijst van personen en instanties.

Annemarie de Wildt (Amsterdam Museum) heeft me geholpen mijn weg te vinden in de historiografie van Amsterdam. De medewerkers van Stadsarchief Amsterdam en met name Hans Visser, Floor Fokkert, Marc Hameleers en Corinne Staal hebben mij wegwijs gemaakt in de archieven of hebben materiaal aangedragen. Het advies van Peter Romijn, Hubert Berkhout en Jeroen Kemperman van het NIOD (Instituut voor Oorlogs-, Holocaust- en Genocidestudies) was onmisbaar bij het vinden van teksten over het geluid van Amsterdam tijdens de Tweede Wereldoorlog. En dankzij Edwin Klijn en Martijn van Wensveen van de KB (Koninklijke Bibliotheek) heb ik in de nog in ontwikkeling zijnde online verzameling 'Historische Kranten' leren navigeren.

Jan van den Noort dank ik voor de uitnodiging om mijn onderzoek te presenteren in de 'Werkgroep Stedengeschiedenis' en voor alle nieuwe informatie, contacten en activiteiten die daarvan het gevolg waren. Zo kwam ik dankzij Petra van Dam (VU) een aantal heiliederen in de liedbank van het Meertensinstituut op het spoor. De presentatie in de werkgroep leidde ook tot een artikel in het tijdschrift Stadsgeschiedenis en Jan bracht mij bovendien in contact met Sible Harmsma (Arcadis) die mij toegang verschafte tot een databank over oude Hinderwetdossiers uit Amsterdam.

$\mathrm{Bij}$ het zoeken naar en het interpreteren van historische Hinderwet gegevens ben ik bovendien geholpen door Floor Fokkert (Stadsarchief Amsterdam), Marius Aalders (UvA), Ernst Homburg en Marc Weerts (UM). En dankzij de waardevolle tips van Jeroen 
Winkels (Radboud Universiteit Nijmegen) vond ik zeldzame en bijzonder interessante verslagen van sociologisch veldwerk dat gedurende het interbellum in Amsterdam is uitgevoerd.

Naast voorgenoemde personen en instanties die hebben geholpen bij het achterhalen van de grondstoffen voor het onderzoek, ben ik ook schatplichtig aan collega's binnen en buiten FASoS (Faculty of Arts and Social Sciences) die hebben geadviseerd bij het schoonmaken, snijden, wegen, kneden en laten gisten van de ingrediënten en het uiteindelijk 'bakken' van het proefschrift. Voor het meedenken over de aanpak van het onderzoek en het commentaar op grote en kleine stukken tekst dank ik Jasper Aalbers, Wiebe Bijker, Carolyn Birdsall, Joeri Bruyninckx, Eefje Cleophas, Leonie Cornips, Darryl Cressman, Piet Devos, Melissa van Drie, Willem Halffman, Anna Harris, Josephine Hoegaerts, Anique Hommels, Frank Huismans, Annemieke Klijn, Stephan Krebs, Jens Lachmund, Daniel Morat, Maaike Meijer, David Nye, Warna Oosterbaan, Constance Sommerey, Alexandra Supper, Sally Wyatt, de redactie en anonieme reviewers van het tijdschrift Stadsgeschiedenis en mijn collegae promovendi van WTMC (Nederlandse Onderzoekschool voor Wetenschap, Technologie en Moderne Cultuur) en de FASoS Graduate School.

Marianne Bittremieux en Rob Rozeboom ben ik veel dank verschuldigd voor het minutieus doorspitten van het manuscript met het oog op tik- en taalfouten en warrige formuleringen en Ton Brouwers voor het vliegensvlug maar desondanks nauwgezet vertalen van de samenvatting. Dank ook aan Peter Kessels voor het herstellen van de kwaliteit van een afbeelding en Rolf Boost, Jaap Hofman en Cathy Van Bauwel - Collet voor toestemming tot het gratis gebruik van een tekening (door Charles Boost), foto (een heimelijke opname van een parade in oorlog door Hofmans vader) en een spotprent (getekend door de grootvader van Van Bauwel - Collet).

Liesbeth van Laar en Eefje Cleophas dank ik omdat ze mij zo geregeld en gulhartig gelegenheid boden om stoom af te blazen en mijn zolder- en kamergenoten Aalok, Alexandra, Andreas, Annette, Erik, Harry, Inge, Johanna, Julia, Ludo, Philip en Ruth voor hun plezierige en stimulerende aanwezigheid. Als laatste wil ik An, Carla, Eefje, Evelien, Pauline en Wilma danken voor het feit dat de band die we tijdens onze studie Cultuurwetenschappen aan de Universiteit Maastricht hebben opgebouwd, ondanks geografische afstanden en drukke agenda's, niet verloren is gegaan. De gepassioneerde discussies naar aanleiding van het lesmateriaal zijn er weliswaar niet meer, maar de bijzonder gezellige bijeenkomsten en hilarische avonturen zo nu en dan gelukkig nog wel.

Ondanks het feit dat ik geprobeerd heb om zo volledig mogelijk te zijn, sluit ik toch niet uit dat ik iemand ben vergeten te noemen. Aan deze persoon of personen de hartelijke uitnodiging om contact op te nemen. Ik kan dan wel geen recht meer doen aan hun bijdrage door het noemen van hun naam in dit proefschrift, maar hoop dat een gezellig onderhoud met koffie en/of een borrel een acceptabel alternatief biedt. 


\section{Het geluid van gisteren: Introductie}

\section{"Woeling en geraas"}

Den Dam, dat middelpunt van woeling en geraas bij dagen en bij nachten! (...) Indien ik van alles spreken wilde, wat er in dien korten tijd al op den Dam (zijnde toen het stadhuis nog in geen paleis herschapen) gebeurde, van koopen en verkoopen, van geeselen en brandmerken, van schreeuwen en zingen, van al het gewoel en geraas van elken vroegen morgen tot elken laten avond, waar zou ik dan een einde vinden? (Potter, 1809, pp. 262-263).

Als de 38 jarige Hebelius Potter in 1807 aankomt in Amsterdam om zich daar als hulppredikant te vestigen, moet hij zich bij gebrek aan een betaalbare woning "drie maanden lang op een klein vertrekje aan den Dam behelpen" (idem). Over dat vertrekje wil hij enkel kwijt dat er van de vroege morgen tot de late avond niet te ontkomen valt aan het gewoel en geraas van de stad. Hij hoort de geluiden van handel, van geschreeuw en gezang en van het uitvoeren van lijfstraffen in het openbaar en hij is er niet blij mee. ${ }^{1}$ "Ligt kunt gij begrijpen, dat, daar ik geen oogenblik stilte, die ik tot mijn geluk zoo noodig heb, als voedsel tot mijn onderhoud, naauwelijks in het holle van den nacht genieten kon, ook een zeer groot gedeelte van mijn geluk vervlogen was" (idem). Bijna tweehonderd jaar later, in 2005, laat de gemeente een onderzoek uitvoeren naar geluidshinder in de stad. Daaruit blijkt dat één op de vijf Amsterdammers veel last heeft van geluid. De meeste overlast wordt veroorzaakt door burengerucht en wegverkeer, gevolgd door bouwwerkzaamheden, vliegtuigen, trams, winkels, bedrijven en treinen. Desondanks vindt bijna driekwart van de Amsterdammers dat een stad zonder geluid een saaie stad is en $69 \%$ is van mening dat geluid Amsterdam levend maakt (Boers \& Bosveld, 2005).

Er is sinds 1807 toen de stad nog volledig door de Singelgracht en het IJ omsloten werd veel veranderd in Amsterdam, maar geluid in allerlei vormen, hinderlijk en niet hinderlijk, is er altijd geweest. Dit laatste geldt natuurlijk voor alle steden - voor zover ze niet verlaten zijn - maar toch 'horen' we daar heel weinig van. Representaties van steden bestaan meestal uit foto's, tekeningen en beschrijvingen van wat er te zien valt. Zelfs bij het gebruik van audiovisuele media bevat de soundtrack vaak veel meer

\footnotetext{
${ }^{1}$ Nederland komt de twijfelachtige eer toe om langer dan enig ander Europees land het brandmerken als straf te hebben gekend en toegepast. Op 29 juni 1854 werd het brandmerken afgeschaft, samen met de eeuwigdurende en de tijdelijke dwangarbeid, verbeurdverklaring van bezit en ontzetting uit de burgerschapsrechten. Het eerste Nederlandse bezwaar tegen het brandmerken stamt uit 1828, ruim 50 jaar nadat Frankrijk in Europa de spits afbeet (Cate, 1975, pp. 8, 123-129).
} 
muziekfragmenten dan geluidsopnames van de stad in kwestie. ${ }^{2}$ Deze beperkte aandacht voor het geluid van de stad in representaties heeft er voor gezorgd dat we weinig weten van het geluid in vroegere steden. Is dat een gemis of kunnen we prima zonder die kennis? Henk Hofland, de columnist, schreef in 1978 dat hij het om reden van nostalgie leuk vond om naar geluiden van gisteren te luisteren, maar dat een systematisch onderzoek naar historische geluiden naar zijn mening verder niets had toe te voegen (Hofland, 2010). Gelukkig liet Hofland het daar niet bij. In juni 2011 wijdde hij een nieuwe overpeinzing aan geluid die als volgt begint:

Een jaar of dertig geleden las ik in de Frankfurter Allgemeine Zeitung een klein essay waarin de schrijver de stelling verdedigde dat de Rechten van de Mens moesten worden uitgebreid met het Recht op Stilte. Misschien had hij overgevoelige trommelvliezen. Het openbaar lawaai was toen nog maar een fractie van wat het nu is. Maar ik was het met hem eens (Hofland, 2011).

Hoewel Hofland een onderzoek naar historisch geluid blijkbaar niet zinvol vindt, is hij er wel van overtuigd dat het lawaai in de grote steden van "de beschaafde geïndustrialiseerde wereld" in 2011 vele malen groter is dan in de jaren zeventig of tachtig van de twintigste eeuw. Met deze opvatting over een steeds toenemend stadsgeluid als resultaat van groei, industrialisering of technologisering, schaart Hofland zich in een rij van respectabele schrijvers en essayisten als Charles Dickens, Georg Simmel en Lewis Mumford (Hard \& Misa, 2008, pp. 1-4; Lees, 1985, pp. 305-309). ${ }^{3}$ Ondanks het feit dat lang niet altijd wordt uitgelegd of de toename van het stadsgeluid te wijten is aan een toename van het aantal geluidsbronnen of een hoger volume per bron, situeren zij het begin van de gezamenlijke groei van de stad en haar geluid in de negentiende eeuw, op het moment waarop de urbanisatiegraad in Europa en Amerika fors toeneemt. De impact van deze innige relatie wordt niet zelden geïllustreerd met dramatisch uitspraken als: "Streets that once were filled with the sounds of children playing were turned into traffic arteries" (Hard \& Misa, 2008, p. 3). ${ }^{4}$

\footnotetext{
${ }^{2}$ Zie bijvoorbeeld: 'Welcome to London - The Greatest City in the World' http://www.youtube.com/watch?v=ilkCpOty5B4\&feature=related, geraadpleegd op 21 juni 2013; 'Tokyo Highlights Afternoon Tour and Sumida River Cruise' http://www.youtube.com/watch?v=ct2cflOHUm8, geraadpleegd op 21 juni 2013; 'Sleepless City - Shanghai' http://www.youtube.com/watch?v=tjXbzkS3fGw, geraadpleegd op 21 juni 2013; "This is Toronto, Canada' http://www.youtube.com/watch?v=CKIqlrpn3bs\&feature=related, geraadpleegd op 21 juni 2013.

${ }^{3}$ Zie voor een uitgebreide opsomming van publicaties die gebaseerd zijn op de veronderstelling dat het geluid van steden alsmaar toeneemt: 'Bang (A Beginning)' voetnoot 12 in (Schwartz, 2011).

${ }^{4}$ De verbeelding van de stad als plaats waar de uitwassen van industrialisatie en technologisering tot uiting komen, past binnen een lange traditie in het negatief bestempelen van de stad. In de klassieke oudheid was de stad een vergaarbak van uitbuiters, in de middeleeuwen een broeinest van ongelimiteerde zondigheid en in negentiende eeuws idioom een 'verterende machine'. Dat betekent echter niet dat de stad altijd in negatieve zin wordt verbeeld. Ze wordt ook als veilige haven getypeerd, als zetel van beschaving of als toevluchtsoord voor minderheden (Pleij, Gemert, \& Mathijsen, 2009).
} 
Inmiddels is deze perceptie van een almaar toenemend geluid in steden zo vanzelfsprekend dat we haar ook aantreffen in introducties van rapporten over geluidshinder, zoals het 'Actieplan Geluid Amsterdam, "Verminder de hinder"' (16-10-08) en het WHO/Europe rapport 'Burden of disease from environmental noise: Quantification of healthy life years lost in Europe' (2011). Maar hoe weten we zo zeker dat het geluid alsmaar toeneemt en dat de stad alsmaar lawaaieriger wordt als we tegelijkertijd nauwelijks op de hoogte zijn van het geluid in vroegere steden? Was het "gewoel en geraas" dat Potter op de Dam hoorde dan zo uitzonderlijk? Waren de straten inderdaad gevuld met het geluid van spelende kinderen voordat het verkeer in de stad toenam? En als dit het geval was, werd dat dan door iedereen gelijk gewaardeerd?

Het antwoord op de laatste vraag kunnen we ook in onze eigen tijd vinden. Sinds 1 januari 2010 is in Nederland wettelijk vastgelegd dat kindergeschreeuw geen geluidsoverlast is. Desondanks waren medio 2011 een aantal dagverblijven in Amsterdam noodgedwongen in overleg met buurtbewoners vanwege klachten over datzelfde kindergeschreeuw (Bronzwaer \& Koning, 2011). Dit voorbeeld maakt in de eerste plaats duidelijk dat het geluid van spelende kinderen ook kindergeschreeuw kan heten en dat het tegelijkertijd wel en geen overlast kan worden genoemd. En in de tweede plaats, dat het geluid van spelende kinderen in de ene context symbool staat voor het idyllische verleden en in de andere voor de kwalen van het moderne stadsleven. We weten niet alleen weinig over het geluid in vroegere steden, maar gaan gemakshalve ook voorbij aan de gecompliceerde en veranderlijke relatie tussen geluid, lawaai en al dan geen overlast. Want zullen wij, net als Hebelius Potter, klagen over het geluid als op een (denkbeeldig) plein tegenover onze woning het gebrul te horen is van personen die zweepslagen krijgen of gebrandmerkt worden?

\section{Centrale vragen}

Hoewel Hofland eind jaren zeventig geen brood zag in het onderzoek naar 'geluid van gisteren', geeft zijn opmerking over alsmaar meer lawaai in de stad en het voorbeeld van de gecompliceerde en veranderlijke betekenis van kindergeschreeuw ons goede redenen om dat onderzoek wel te doen. Naarmate we over meer informatie over het 'geluid van gisteren' beschikken, verminderen we de kans dat we actuele debatten over geluid en lawaai vertroebelen met een vertekend historisch perspectief en te simpele veronderstellingen over de rol van geluid in het dagelijkse stadsleven.

De eerste stap is dan het beantwoorden van de vraag wat hier onder stadsgeluid wordt verstaan. Dat lijkt eenvoudiger dan het is, want om te beginnen is er verschil tussen de geluiden die in, onder en boven de stad worden gemaakt en de geluiden die op al die plaatsen worden gehoord. Zelfs als we uitgaan van het standpunt dat het begrip 'geluid' impliceert dat het om geluidsgolven gaat die in principe door de mens gehoord kunnen worden, wordt toch niet alle 'geluid' dat in de stad wordt gemaakt 
ook daadwerkelijk gehoord. ${ }^{5}$ Het geluid dat muizen in rioleringsstelsels onder de stad maken, zal bijvoorbeeld zelden door stadsbewoners worden waargenomen. ${ }^{6}$ In dit onderzoek gaat het echter om geluiden die op welke manier dan ook iets te betekenen hebben voor de bewoners en bezoekers van de stad. Deze geluiden worden hier onder de categorie 'gehoorde' geluiden geschaard. De categorie 'gehoorde geluiden' is dus het stadsgeluid of het klanklandschap waarmee de stedeling in zijn dagelijkse leven te maken heeft en waarover hij of zij met tijdgenoten kan communiceren, om het even of men het eens of oneens is over de eigenschappen en betekenis van deze geluiden. Het begrip 'klanklandschap' of 'soundscape' dat hier wordt gebruikt verwijst dan ook tegelijkertijd naar een wereld buiten de mens - de geluiden die mensen omringen - als naar datgene waarmee de mens die buitenwereld probeert te begrijpen ( $E$. Thompson, 2002 , p. 1). Daarbij wordt er van uitgegaan dat "datgene waarmee de mens de buitenwereld probeert te begrijpen" tot op zekere hoogte gedeeld wordt door tijdgenoten, want anders kan er van communicatie geen sprake zijn. ${ }^{7}$

Zoals in het volgende hoofdstuk nog zal worden besproken, houdt de gelaagdheid van het begrip klanklandschap ook in dat de betekenis van en het oordeel over geluid gebonden is aan plaats en tijd. Het luisteren naar een opname van stadsgeluid uit het verleden, ook als we weten waar en wanneer die opname is gemaakt, vertelt ons niet wat het voor tijdgenoten inhield om in het dagelijks leven met dat geluid te maken te hebben. Zonder aanvullende informatie over op zijn minst de betekenis van die geluiden voor tijdgenoten, is de kans groot dat we een dergelijke opname beluisteren vanuit ons hedendaagse referentiekader en onze 'beleving' van het geluid op het verleden projecteren. ${ }^{8} \mathrm{Om}$ inzicht te verwerven in de wijze waarop tijdgenoten het

\footnotetext{
${ }^{5}$ Om de situatie niet nog ingewikkelder te maken dan hij al is, wordt hier niet verder ingegaan op de complexiteit en gelaagdheid van de begrippen 'geluid', 'horen' en 'luisteren' en hun onderlinge verbanden. Geluid bijvoorbeeld wordt vaak gedefinieerd als de reeks van frequenties waarvoor het gehoor van de 'gemiddelde' mens behorende tot een bepaalde leeftijdscategorie 'in principe' gevoelig is. De vraag is dan wie die 'gemiddelde' mens is en waar en wanneer hij leefde, want zelfs de 'mechanische' gevoeligheid van het menselijk oor staat niet los van omgevingsfactoren (Schwartz, 2011, pp. 11-12; Sterne, 2003). Ook is het niet ongebruikelijk om te zeggen "ik hoor je niet" om aan te geven dat we niet (willen) luisteren en ook 'luisteren' kent vele vormen. Voor een overzicht van publicaties op het vlak van horen en luisteren vanuit uiteenlopende disciplines (filosofie, cultural studies, esthetica, antropologie, wetenschap en techniek studies, media studies) zie het eerste deel van The Sound Studies Reader (Sterne, 2012, pp. 19-90).

${ }^{6}$ In de uitzonderlijke situatie waarin muizen in ondergrondse rioleringsstelsels wel gehoord worden door stadsbewoners, zullen deze geluiden waarschijnlijk zeer betekenisvol zijn en zal er veel aandacht aan worden besteed.

${ }^{7}$ De oorspronkelijke tekst van Thompson luidt: "Like a landscape, a soundscape is simultaneously a physical environment and a way of perceiving that environment; it is both a world and a culture constructed to make sense of that world" (E. Thompson, 2002, p. 1). Deze en alle andere vertalingen naar het Nederlands zijn, tenzij anders vermeld, van Annelies Jacobs.

${ }^{8}$ Bovendien bestaat hier ook het gevaar dat we bepaalde geluiden als onveranderlijk beschouwen, diergeluiden bijvoorbeeld, terwijl we daar niet zeker van kunnen zijn. Onderzoek naar zangvogels bijvoorbeeld heeft aangetoond dat hun gezang beïnvloed wordt door omgevingsgeluid. Zie website http://www.sciencedaily.com/releases/2012/04/120402162710.htm, geraadpleegd op 21 juni 2013.
} 
stadsgeluid 'beleven' zijn ook teksten of andere media nodig waarin uitdrukking is gegeven aan de geluiden die ze horen, de betekenissen die ze er aan geven, het oordeel dat ze erover vellen en de eventuele veranderingen die wenselijk of noodzakelijk worden geacht.

We kunnen er echter niet van uitgaan dat in deze media alle geluiden worden opgesomd die men gehoord heeft. De keuze om bepaalde geluiden aan de orde te stellen en andere niet draagt op zichzelf betekenis en is daarom van belang voor dit onderzoek. Dit houdt in dat we naast de uitspraken van tijdgenoten over de geluiden die ze horen, ook informatie nodig hebben over de activiteiten en gebeurtenissen die plaatsvinden in de stad. Op basis daarvan kan immers een inschatting worden gemaakt van de geluiden die men redelijkerwijs gehoord zou kunnen hebben. Daarbij moet onder meer gedacht worden aan de geluiden veroorzaakt of beïnvloed door werkzaamheden op straat en in gebouwen, de apparatuur die daarbij wordt gebruikt, het aantal bewoners per woning, de intensiteit en de aard van de verschillende categorieen verkeersdeelnemers, de aard van de bebouwing en het soort plaveisel in de straten.

In dit onderzoek naar de gecompliceerde en veranderlijke relatie tussen stadsgeluid, oordelen over dat geluid en voorstellen tot interventie zijn tekstfragmenten over geluid het primaire bronmateriaal. Tekst is namelijk het enige medium dat beschikbaar was gedurende de tijdvakken 1875-1895, 1918-1940 en 1940-1945 die hier aan de orde komen, een keuze die verderop wordt toegelicht. Door de beperkte aandacht voor geluid is het opsporen van bruikbare tekstfragmenten niet alleen arbeidsintensief, maar is het ook niet mogelijk om het onderzoeksmateriaal te beperken tot één type bron. Vandaar dat in dit onderzoek gebruikt wordt gemaakt van zowel publieke teksten (kranten, gemeenteverslagen, brieven aan kranten, reisverslagen, gepubliceerde memoires) als private geschriften (ongepubliceerde dagboeken) die betrekking hebben op het reilen en zeilen in de stad in de onderzochte periode en bovendien in die tijd zelf geschreven zijn. Voor informatie over gebeurtenissen, activiteiten en materiele eigenschappen van het leven in de stad wordt bovendien gebruikt gemaakt van secundaire literatuur. Op basis van dit materiaal worden voor de genoemde drie tijdvakken uit de geschiedenis van een en dezelfde stad, Amsterdam in dit geval, de volgende vier vragen beantwoord:

1. Welke stadsgeluiden worden in publieke en private teksten besproken als het geluid dat gehoord wordt? Welke bronnen van geluid zijn er verder nog aanwezig? Welke veranderingen in de aard, het aantal en het volume van die geluiden doen zich voor?

2. Hoe worden stadsgeluiden besproken en welke betekenissen kent men eraan toe? Welke geluiden worden bij voorbeeld door wie als ongewenst beschouwd?

3. In hoeverre wordt er geluid gemaakt om de aandacht te vestigen op bepaalde situaties of opvattingen? Worden er interventies ter bestrijding van stadsgeluiden voorgesteld en/of uitgevoerd? Zo ja, welke? 
4. Hoe zijn de verschillen tussen de productie van geluiden, het bespreken van geluiden en het interveniëren in en met geluiden te begrijpen en te verklaren?

\section{Geluid onder de loep}

Onderzoeken zoals dit behoren tot de zogeheten Sound Studies, een interdisciplinair onderzoeksveld naar de productie en de consumptie van muziek, geluid, lawaai en stilte en de veranderingen die daarin in de loop van de geschiedenis en in uiteenlopende samenlevingen hebben plaatsgevonden (Pinch \& Bijsterveld, 2012, pp. 6-7). Een klein deel van het onderzoek binnen Sound Studies is specifiek gericht op stadsgeluid. Soms gaat het daarbij om het geluid in een specifieke stad, bijvoorbeeld Hannover, Wenen of Londen (Birkefeld \& Jung, 1994; Payer, 2007; Picker, 2000). Andere publicaties over stadsgeluid zijn gebaseerd op meerdere steden van een land, van Europa of Noord-Amerika (Arkette, 2004; Atkinson, 2007; Bijsterveld, 2003; Saul, 1996a; Smilor, 1977; Toyka-Seid, 2005). Al deze onderzoeken gaan óf over een aaneengesloten periode die varieert van een eeuw tot enkele decennia óf over een niet nader gespecificeerd recent verleden.

Aan de kennis die deze onderzoeken hebben opgeleverd op het vlak van veranderingen in het geluid in Westerse steden, het oordeel over die veranderingen, de geschiedenis van anti-lawaaibewegingen en de beweegredenen van anti-lawaai activisten, wil deze dissertatie een bijdrage leveren door de productie en de consumptie van stadsgeluid in een en dezelfde stad over drie afzonderlijke periodes te onderzoeken. Dat maakt het in de eerste plaats mogelijk om per periode dieper in te gaan op het klanklandschap van die tijd. In de tweede plaats, maar niet minder belangrijk, zorgt deze opzet ervoor dat de verhouding tussen enerzijds de geluiden die in een bepaalde periode geproduceerd worden en anderzijds de betekenis van die geluiden en de (gewenste) interventies in het stedelijk klanklandschap -- na de vergelijking van tijdvakken -- veel nauwkeuriger in beeld kunnen worden gebracht en verklaard dan wanneer een groot geografisch gebied wordt onderzocht.

Kennis over het geluid van gisteren kan ook helpen om een beter onderbouwd gevoel te ontwikkelen voor de geleidelijke maar daarom niet minder ingrijpende veranderingen in de 'materialiteit' van het dagelijks leven in het verleden en hoe deze tegelijkertijd oorzaak en gevolg was van verschuivende opvattingen over het stadsleven. De resultaten van dit onderzoek zijn daarom ook relevant voor situaties waarin zo 'realistisch' mogelijke representaties worden nagestreefd van steden en het stadsleven in het verleden, heden en de toekomst. Ze stellen musea, en in bijzonder het Amsterdam Museum, in staat om in cultuurhistorische presentaties van het stadsleven visuele en auditieve elementen uit het verleden op te nemen en deze te verrijken met informatie over de betekenis van bepaalde geluiden voor tijdgenoten en de rol die ze 
destijds speelden in discussies over het leven in de stad. ${ }^{9}$ Dat voorkomt dat de historische complexiteit van de betekenis van beelden en geluiden verloren gaat en het zorgt en passant ook voor een betere toegankelijkheid van informatie en educatie voor personen met een visuele beperking.

Tenslotte wil dit onderzoek, zij het in indirecte zin, een bijdrage leveren aan Urban Studies, het interdisciplinaire onderzoek naar de hedendaagse stad in al haar dimensies. Enerzijds door de aandacht te vestigen op aspecten van zintuiglijke ervaring of 'materialiteit' van (openbare) ruimte die van groot belang zijn in het dagelijks leven, maar in onderzoeken naar en plannen voor de stad letterlijk en figuurlijk 'over het hoofd worden gezien' door de diep ingesleten voorliefde voor visuele representaties en modellen. ${ }^{10}$ Anderzijds door aan te tonen dat de ervaring van die 'materialiteit' niet op zichzelf staat, niet volledig inherent is aan objecten of aan de openbare ruimte, maar mede bepaald wordt door de betekenis die er in sociale en culturele processen aan wordt toegekend.

\section{Het geluid van Amsterdam}

Om een antwoord te kunnen geven op de centrale vragen van dit onderzoek, wordt stadsgeluid geanalyseerd met hulp van een raamwerk dat opgebouwd is uit drie verschillende perspectieven. In de eerste plaats wordt ingegaan op de geluiden die in een bepaalde periode worden gemaakt. Welke geluiden zijn dat? Is er sprake is van een toename van de bronnen die dit geluid voortbrengen? Verandert er iets in het volume van dit geluid? En zijn er nieuwe geluiden of geluiden die verdwijnen? Dit perspectief noem ik de 'ecologie van geluid'. Het tweede perspectief, 'semiotiek van geluid' genaamd, heeft betrekking op de betekenis van geluid en leidt in principe tot drie vragen. Zijn er in de gegeven periode opvallende veranderingen in de betekenis van bepaalde geluiden? Is er een voorkeur voor bepaalde woorden bij het beschrijven van geluiden? En indien men in die periode van mening is dat het stadsgeluid verandert, welke betekenis wordt dan aan die verandering toegekend? Het derde en laatste perspectief, de 'politiek van geluid' richt de aandacht op de wijze waarop geluid

\footnotetext{
${ }^{9}$ Voor een beknopt overzicht van het gebruik van geluid in musea zie (Bijsterveld, Jacobs, Aalbers, \& Fickers, 2013). Voor informatie over de klankinstallatie 'Het geluid van Amsterdam' in het Amsterdam Museum, waarvoor gebruik is gemaakt van dit onderzoek. Zie website http://amsterdammuseum.nl/het-geluid-vanamsterdam, geraadpleegd op 21 juni 2013.

${ }^{10}$ Het ligt buiten mijn vermogen om antwoord te geven op de vraag waarom er zo weinig aandacht wordt besteed aan geluid bij het representeren van architectuur en steden en voor zover mij bekend is die vraag ook niet door anderen overtuigend beantwoord. Er zijn wel publicaties die aannemelijk maken waarom visuele representaties in de wetenschap een prominente rol spelen (Lynch \& Woolgar, 1990; Pauwels, 2006). Zie 'Bang (A Beginning)' in Making Noise: From Babel to the Big Bang \& Beyond van Hillel Schwartz (2011) voor een overzicht van onderzoek op het gebied van Sound Studies dat in de toekomst mogelijk aanknopingspunten zal kunnen bieden voor een verklaring van het gebrek aan aandacht voor auditieve kwaliteiten bij het representeren van gebouwen en openbare ruimte.
} 
een rol speelt bij feitelijke of gewenste interventies (in het dagelijks leven) in de stad. In hoeverre wordt in de betreffende periode geluid gemaakt om de aandacht te vestigen op bepaalde situaties of opvattingen? En welke onderdelen van het stadsgeluid spelen een rol bij discussies over en interventies in aspecten van het stadsleven die anders zouden moeten of kunnen zijn?

Het analyse-raamwerk, waarvan de herkomst in het volgende hoofdstuk wordt toegelicht, wordt toegepast op de drie genoemde tijdvakken in de geschiedenis van een en dezelfde stad, Amsterdam in dit geval. Elke periode moet daarbij gezien worden als een specifieke casus van het verschijnsel stadsgeluid. De keuze voor Amsterdam is ingegeven door het feit dat deze stad sinds het midden van de negentiende eeuw exemplarisch is voor het fenomeen 'grote stad' in Nederland en ook internationaal de meest bekende Nederlandse stad is (Rooy, 2007c, p. 584). Bovendien heeft het merendeel van de publicaties over historische klanklandschappen betrekking op nationale hoofdsteden en dat vergroot de mogelijkheid tot onderlinge vergelijking. In aanvulling op de commerciële activiteiten die kenmerkend zijn voor steden fungeren hoofdsteden doorgaans ook als podia voor nationale publieke rituelen op het vlak van politiek en cultuur (Cowan \& Steward, 2007b, p. 9).

De selectie van de casussen of tijdvakken 1875-1895, 1918-1940 en 1940-1945 komt voort uit de vraagstelling van dit onderzoek in combinatie met kennis over ontwikkelingen in stadsgeluid die andere publicaties binnen Sound Studies ons hebben gebracht. Bovendien heeft de toepassing van het analyse raamwerk een rol gespeeld bij het selecteren van casussen. Er is naar gestreefd om naast een systematische analyse van elke casus met behulp van alle drie de perspectieven, per casus op één van de afzonderlijke perspectieven dieper in te gaan. De periode 1875-1895 is voor dit onderzoek relevant omdat Amsterdam dan te maken krijgt met de bevolkingsgroei en industrialisering die in veel andere Europese steden in de eerste helft van de negentiende eeuw heeft plaatsgevonden. Amsterdam wordt dan voor het eerst geconfronteerd met 'modern' stadsgeluid en daarom is er in deze casus extra aandacht voor de ecologie van geluid. Het interbellum (1918-1940) is vervolgens een periode die voor Amsterdam qua groei van de bevolking, industrialisering en technologisering vergelijkbaar is met het eind van de negentiende eeuw, maar waarin - zoals we weten uit literatuur over andere steden (Bijsterveld, 2008, pp. 5-6, 101, 112) - geluid en lawaai meer dan voorheen aan de orde komt in discussies over en interventies in het stadsleven. In deze casus ligt de nadruk op de politiek van geluid. En de Tweede Wereldoorlog tenslotte, is relevant omdat er geen andere periode of situatie denkbaar is waarin de Amsterdammers zo abrupt geconfronteerd worden met geluiden die nieuw zijn, die verdwijnen of een heel andere betekenis krijgen. Deze casus biedt een goede gelegenheid om nadrukkelijker stil te staan bij de semiotiek van geluid. 


\section{De plot van dit boek}

In dit boek 'luisteren' we enkel via teksten naar het verleden en bovendien in tweeërlei opzicht. Zoals eerder al is toegelicht, is dit onderzoek naar het stadsgeluid van gisteren uitsluitend gebaseerd op teksten en tekstfragmenten over dat geluid. Die keuze hangt samen met de beschikbaarheid van dit medium tijdens alle periodes die bestudeerd worden. Het tweede aspect van het luisteren naar het verleden via tekst, heeft betrekking op het boek dat $u$ nu in handen heeft. Dit gaat niet vergezeld van een CD of verwijzing naar geluidsdragers op het internet, maar bevat een groot aantal citaten uit het bronmateriaal. Via die citaten kunnen we luisteren naar de wijze waarop tijdgenoten datgene wat ze hoorden en hun mening daarover letterlijk en figuurlijk beoogden te verklanken via woordkeuze, zinsopbouw en lijn van argumentatie. Dit betekent in feite het luisteren naar het discours over geluid, waarbij het begrip 'discours' gedefinieerd kan worden als het samenstel van ideeën, concepten en woorden dat wordt gebruikt om betekenis te geven aan ervaringen (Hajer \& Versteeg, 2005, pp. 175-178). Bovendien benadrukken de voor hedendaagse Nederlandse lezers direct herkenbare 'ouderwetse' woorden en formuleringen, elke keer opnieuw en gemakkelijker dan een beschrijving dat zou kunnen, de afstand tussen onze actuele en de betreffende historische situatie.

In het laatste hoofdstuk van dit boek wordt antwoord gegeven op de vraag hoe de verschillen tussen de productie van geluiden, het bespreken van geluiden en het interveniëren in en met geluiden te begrijpen en te verklaren is. Aan deze 'ontknoping' gaan drie hoofdstukken vooraf waarin steeds opnieuw, maar telkens voor een andere periode, antwoorden worden gezocht op vragen die voortkomen uit de drie verschillende perspectieven (ecologie, semiotiek, politiek) van waaruit we het Amsterdamse klanklandschap onderzoeken. Voorafgaand aan al die 'geluiden van gisteren' wordt in het volgende hoofdstuk uitleg gegeven over de ontwikkeling van het begrip soundscape en de herkomst van het analyseraamwerk aan de hand van een overzicht van de literatuur over historische klanklandschappen. Bovendien wordt er dieper ingegaan op het bronnenmateriaal en de onderzoeksmethode. Aan het slot van deze introductie van Het geluid van gisteren: waarom Amsterdam vroeger ook niet stil was, wil ik als opmaat tot de overige hoofdstukken van dit boek met behulp van een citaat nog even stilstaan bij de aspecten van geluid die het tot zo'n fascinerend onderwerp voor onderzoek maken, om het even of het over het geluid van vandaag of over dat van gisteren gaat. "As soon as sound has arrived, it has gone, and yet it fills every inch of space, seeps out from underneath doorways and through walls, surrounding us in invisible presence" (Anderson, 2012). 



\section{Luisteren naar het verleden: Analytisch raamwerk, methoden en bronnen}

\section{Soundscapes}

Het voorgaande hoofdstuk werd afgesloten met een citaat dat de eigenaardigheid van geluid in één zin probeert te vatten. Een deel van die zin is te vertalen als "zodra geluid is aangekomen, is het verdwenen" (Anderson, 2012). Zo beschouwd is geluid bijna per definitie 'van gisteren', maar dat is niet bedoeld met de titel van deze dissertatie. In dit onderzoek gaat het om de geluiden die in het verleden voor 'bewoners' van Amsterdam het klanklandschap of de 'soundscape' vormden waarin hun dagelijks leven en handelen zich afspeelde en dat voor hen op een of ander manier betekenisvol was. De samenhang tussen de geluiden die in een bepaalde historische periode in Amsterdam geproduceerd werden, genoemd werden, belangrijk werden gevonden, commotie veroorzaakten en eventueel in interventies een rol speelden, staat daarbij centraal. We 'luisteren naar het verleden' om meer te weten te komen over mogelijke patronen in die samenhang. Dit in tegenstelling tot onderzoeken naar het actuele klanklandschap van locaties, die meestal worden uitgevoerd om in die soundscapes in te (kunnen) grijpen. Die interventies kunnen de vorm hebben van een kunstwerk of performance met geluid, maar ook van maatregelen die de productie en/of hinder van bepaalde stadsgeluiden moeten tegengaan. Wat beide soorten van onderzoek gemeen hebben is dat ze de ecologische dimensie van geluid, geluid in de leefomgeving van de mens, centraal stellen en daarbij gebruik maken van het begrip 'soundscape' van componist en milieuactivist Raymond Murray Schafer.

In de jaren zeventig van de vorige eeuw vroeg Schafer, onder meer via het boek The soundscape: Our sonic environment and the tuning of the world, aandacht voor de verandering die de industriële revolutie heeft veroorzaakt in de dagelijkse geluiden die de mens omringen (Schafer 1994/1977). Schafer muntte niet alleen het begrip 'soundscape' maar stond ook aan de wieg van wat tegenwoordig het World Soundscape Project heet. ${ }^{11}$ Doel van dit project is het documenteren van veranderingen in het klanklandschap van de (Westerse) wereld door het verzamelen van geluidsopnames. "I honestly believe we were the first people to take the microphone out of the studio to make phenomenological recordings, that is to record phenomena in their native environment without trying to mediate or manipulate the material for other

\footnotetext{
${ }^{11}$ Zie website http://www.sfu.ca/ truax/wsp.html, geraadpleegd op 21 juni 2013.
} 
purposes" zei Schafer in een lezing aan het Canadian Centre for Architecture in het najaar van $2005 .^{12}$

In de periode dat Schafers boek verscheen, kwam in Frankrijk het onderzoek naar historisch geluid op gang. Dit culmineerde in Alain Corbins succesvolle boek over de veelzijdige functie en betekenis van kerkklokken voor het dagelijks leven op het Franse platteland in de negentiende eeuw. De klokken gaven het ritme van de dag aan, communiceerden waarschuwingen, hielpen bij het vinden van de goede richting in het omringende land en gaven uitdrukking aan de identiteit van gemeenschappen (Corbin, 1998). Corbin beargumenteerde bovendien dat de betekenis van geluid en de manier van luisteren gebonden is aan plaats en tijd (Corbin, 1995). ${ }^{13}$ Meer recente publicaties in Sound Studies gaan uitgebreid in op deze relatie tussen culturele context enerzijds en betekenis van geluid en veranderingen in de manier van luisteren anderzijds (Bijsterveld, 2003; Bull \& Back, 2003; Sterne, 2003; E. Thompson, 2002). In aanvulling daarop laten andere werken zien dat conflicten over geluid ook vaak gepaard gaan met spanningen tussen groepen in de samenleving en strijd over wie wel of niet gehoord mag worden (Bijsterveld, 2001; Coates, 2005; Picker, 2000; Smith, 2001).

Schafers begrip 'soundscape' heeft sinds de introductie in 1977 breed weerklank gevonden (Kelman, 2010). Het wordt niet meer alleen gebruikt om het geluid in (een gedeelte van) de actuele of de historische leefomgeving van de mens (stad, buurt, dorp, platteland) aan te duiden, maar ook voor het geluid in (muziek)studio's, van films en videogames, van geluidscreaties als hoorspelen en zelfs voor de softwarematige omzetting van de vorm van een letter in geluid die blinde personen in staat stelt gedrukte tekst te 'lezen' (Bandt, Duffy, \& MacKinnon, 2009; Crook, 2012; Ripley, Polo, \& Wrigglesworth, 2007; Samuels, Meintjes, Ochoa, \& Porcello, 2010, p. 331). ${ }^{14}$ In deze dissertatie gaat het uiteraard wel om het geluid in de leefomgeving, maar ook hier wordt een definitie van de term 'soundscape' gebruikt die uitgebreider is dan het oorspronkelijke "the sonic environment" van Schafer (Schafer, 1977/1994, p. 274). Zoals eerder vermeld, is hier de definitie van Emily Thompson uitgangspunt waarbij de term 'soundscape' zowel naar een wereld buiten de mens verwijst - de geluiden die

\footnotetext{
${ }^{12}$ Zie website http://www.david-howes.com/senses/sensing-the-city-lecture-RMurraySchafer.htm, geraadpleegd op 21 juni 2013.

${ }^{13}$ De notie dat de betekenis van geluid en de manier van luisteren niet los staan van de culturele context van de waarnemer, is onderdeel van de opvatting dat alle vormen van zintuiglijke waarneming en de betekenis die daaraan wordt toegekend niet universeel en ahistorisch is. "The investigation of the sensory worlds of past eras should not merely describe the range of sounds and smells that existed in a particular time, as evocative as that might be, but should uncover the meanings those sounds and smells had for people" (Classen, 2001).

${ }^{14}$ Het software programma vOICe, ontwikkeld door natuurkundig ingenieur Peter Meijer, zet tekens (in principe alle beelden) die door een camera worden geregistreerd aan de hand van variatie in luidheid en toonhoogte om in een digitaal 'geluidsfragment'. Dit geluidsfragment wordt soundscape genoemd. De (blinde) persoon krijgt de 'soundscape' via een oortje te horen en is na enige training in staat om het teken dat de camera 'ziet' te 'lezen' (Voormolen, 2012).
} 
mensen omringen - als naar de manier waarop de mens die buitenwereld waarneemt en er betekenis aan geeft (E. Thompson, 2002, p. 1). De toevoeging van een tweede laag aan de oorspronkelijke definitie van Schafer zorgt er voor dat het door Corbin geformuleerde uitgangspunt, dat de betekenis van geluid en de wijze van luisteren niet universeel en ahistorisch is maar gebonden aan plaats en tijd, nu onderdeel uitmaakt van het begrip (Sterne, 2013, p. 182).

\section{Analytisch raamwerk}

Dit onderzoek naar de gecompliceerde en veranderlijke relatie tussen stadsgeluid, oordelen over dat geluid en voorstellen tot interventie weerspiegelt de gelaagdheid van Thompsons definitie van een soundscape. Het gaat hier enerzijds om veranderingen in de geluiden die in de leefomgeving van de stadsbewoner worden geproduceerd en anderzijds om de manier waarop de stedeling aandacht besteedt aan die geluiden of ze juist negeert. Van een gegeven en onveranderlijke relatie tussen geluid en betekenis van of oordeel over dat geluid wordt hier dus niet uitgegaan, maar dat hoeft nog niet te betekenen dat die relatie volledig bepaald wordt door toevallige omstandigheden. Om zicht te krijgen op mechanismen die bij de totstandkoming van betekenis en oordeel over geluid mogelijk een rol spelen, wordt in deze dissertatie aan de hand van drie casussen stilgestaan bij historische en lokale factoren die verklaren waarom in een gegeven periode bepaalde geluiden in Amsterdam genoemd worden en belangrijk worden gevonden en andere geluiden niet. Per casus, dat wil zeggen per historische periode, wordt ingezoomd op de samenhang tussen de geluiden in de omgeving van de stedeling en de aandacht die aan deze geluiden wordt besteed, de betekenis die er aan wordt toegekend en de manier waarop die geluiden een rol spelen in discussies over het leven in de stad. Daarbij is gebruik gemaakt van het analyseraamwerk dat in het eerst hoofdstuk al kort werd beschreven en onderstaand nog verder zal worden toegelicht. Vervolgens wordt in het laatste hoofdstuk van dit boek, op basis van een vergelijking van de drie casussen, ingegaan op de vraag in hoeverre er sprake is van patronen in de relatie tussen geproduceerd geluid en aandacht voor of commotie over dat geluid die gelden voor alle periodes. Dan wordt het geschiedkundige 'oor' waarmee naar de drie historische periodes is geluisterd vervangen door een exemplaar dat is afgestemd op sociologische verklaringsmechanismen.

Doel van de analyse met behulp van de drie perspectieven in het raamwerk ecologie, semiotiek en politiek van geluid - is om per casus uiteen te rafelen hoe deze drie aspecten van geluid zich tot elkaar verhouden. Elk afzonderlijk perspectief biedt de mogelijkheid om grip te krijgen op een deel van de complexe en dynamische aspecten van het klanklandschap. Het raamwerk is echter geen model van een klanklandschap, net zomin als een klanklandschap een optelsom is van de resultaten die de drie perspectieven te zien geven. Elk perspectief kan vergeleken worden met een lens die 
het de analist mogelijk maakt om zich te richten op een bepaald deel van het onderzoeksveld. Toepassing van de drie perspectieven naast elkaar voor elke casus of onderzoeksperiode, helpt om de vraag te beantwoorden waarom in bepaalde perioden meer of minder aandacht is voor bepaalde typen van geproduceerd geluid, of waarom de manier waarop dat geluid wordt besproken verandert.

In het eerste perspectief, de 'ecologie van geluid' wordt geluid gezien als een verschijnsel dat zich in de omgeving van de mens voordoet. Het geluid wordt veroorzaakt door activiteiten die op een bepaalde locatie plaatsvinden en beïnvloed door de materiële kwaliteiten van diezelfde locatie. Om een voorbeeld te geven: in een stad met hoge gebouwen wordt geluid op een andere manier door de omgeving weerkaatst dan in een stad met lagere gebouwen. Bij dit perspectief wordt er, vaak impliciet, van uitgegaan dat wie de bronnen en transmissie van geluid op een bepaalde plaats gedocumenteerd heeft, het klanklandschap wel heeft 'gevangen'. Of wanneer het om veranderingen in geluidsbronnen en -transmissie gaat: dat de geschiedenis van geluid daarmee verteld is.

In het tweede perspectief is geluid een soort 'informatiesysteem' dat gedurende een bepaalde periode voor de bewoners van een bepaalde locatie operationeel is. De informatie die 'ingezetenen' ontlenen aan geluid is niet alleen gebaseerd op expliciete afspraken over de betekenis van signalen, de zes slagen van de kerkklok in de vroege ochtend die mij vertellen hoe laat het is bijvoorbeeld, maar ook op ervaringskennis. Zo weten mijn buren en ik dat het ongeveer zes uur in de ochtend is en dat de krant wordt bezorgd, als we het geluid van een bromfiets horen in de doorgang naar het plein achter onze woningen. Dit perspectief noem ik de 'semiotiek van geluid', omdat geluid hier functioneert als een teken dat verwijst naar een gebeurtenis of toestand en door degenen die het horen op een bepaalde manier wordt geïnterpreteerd.

Het derde perspectief tenslotte, de 'politiek van geluid', gaat over geluid als onderdeel van politieke en sociale kwesties. Geluid kan daarbij uitdrukking geven aan omstreden situaties of gebeurtenissen, een demonstratie met ketelmuziek bijvoorbeeld, maar ook zelf het onderwerp van discussie zijn. Het gaat hierbij om allerlei vormen van machtsstrijd. In afwijking van het eerste, houden het tweede en derde perspectief rekening met het uitgangspunt dat betekenis van en het oordeel over geluid gebonden is aan plaats en tijd. Dit houdt in dat er geen directe universele en ahistorische relatie is tussen het geluid dat wordt geproduceerd in de omgeving van de mens en diens eventuele reactie, maar dat er een gelaagde en grotendeels onbewuste 'vertaling' plaatsvindt die gebaseerd is op sociale, culturele en zelfs individuele codes.

Ik ben tot het analyseraamwerk gekomen op basis van een onderlinge vergelijking en categorisering van publicaties over klanklandschappen. Deze werken worden onderstaand kort besproken in relatie tot de afzonderlijke perspectieven van het raamwerk. Bovendien wordt, waar dat van toepassing is, aangegeven op welke manier de betreffende publicatie mijn eigen onderzoek nog op andere manieren vooruit heeft geholpen. Met uitzondering van enkele vroege werken over soundscapes uit de jaren 
zeventig van de vorige eeuw, zoals de reeds genoemde boeken van Corbin en Schafer, zijn het publicaties over het geluid van de stad. In deze werken vinden we benaderingen van het onderzoeksveld die enerzijds samenhangen met de gehanteerde definitie van het begrip soundscape en anderzijds met de (academische) achtergrond en beweegredenen van de auteurs. Zoals eerder al is aangegeven zijn onderzoeken naar de actuele soundscape van een stad doorgaans ingegeven door de wens of behoefte om daarin te kunnen interveniëren. In principe kunnen de verschillende benaderingen tot de drie beschreven perspectieven worden teruggebracht. Het merendeel van de onderzochte publicaties blijkt (stads)geluid vanuit twee of soms zelfs alle drie de perspectieven te beschouwen, zonder dat de overgang van de ene benadering naar de andere expliciet wordt in het artikel, hoofdstuk of boek.

\section{Ecologie van geluid}

Het eerste perspectief, waarin geluid gezien wordt als een omgevingsfactor die grote invloed uitoefent op het leven van mensen, is duidelijk herkenbaar in het werk van Schafer en van de Franse historicus Guy Thuillier. Uit Schafers poging om soundscapes te bewaren met behulp van geluidsopnames en Thuilliers streven om historische klanklandschappen toegankelijk te maken door de geluiden die gehoord werden in kaart te brengen, blijkt dat beide auteurs een groot belang toekennen aan de aard van het geproduceerde geluid (Schafer, 1977/1994; Thuillier, 1977). Dit geldt tot op zekere hoogte ook voor artikelen over stadsgeluid van Arkette, Atkinson, Payer, Saul, Smilor en Toyka-Seid.

Sound designer en theoreticus Sophie Arkette staat weliswaar kritisch tegenover het werk van Schafer, in het bijzonder ten opzichte van diens "romantic bias towards antiquarian or rural soundscapes", maar is toch zelf vooral geïnteresseerd in "the urban sonic fabric" en "the acoustic territory" en de effecten er van op de luisteraar (Arkette, 2004, p. 167). Zij zou graag zien dat er meer aandacht wordt besteed aan de akoestische aspecten van de stedelijke ruimte, omdat dit de kwaliteit van de urbane leefomgeving aanmerkelijk zou kunnen verbeteren. Aan het werk van Rowland Atkinson, die op het vlak van Urban Studies en criminologie onderzoek doet naar processen van in- en uitsluiting, heb ik het label 'ecologie van geluid' ontleend voor dit eerste perspectief. Atkinson, die een lans breekt voor het ontwikkelen van het concept 'sonic ecology', legt de nadruk op "the resonant metropolitan fabric, which may exclude or subtly guide us in our experience of the city (...)" (Atkinson, 2007, p. 1905). Hij wil uiteindelijk in staat zijn om stedelijke klanklandschappen te ontwerpen en te beheersen en maakt daarvoor onderscheid tussen twee niveaus van activiteiten. Het eerst niveau is dat van geluid in de omgeving van de mens dat direct inwerkt op diens welbevinden en gedrag. Dit geluid wordt voortgebracht door mens, dier en technische middelen (apparaten, verkeer en industrie) of door deze middelen beïnvloed (zoals het profiel van en de gebruikte materialen in gebouwen en straten). Het tweede niveau 
van activiteiten dat Atkinson onderscheidt, is het gebruik of het aanpassen van deze 'technologieën' met de bedoeling de aard van het geluid rondom de mens te beïnvloeden. Atkinson gaat er van uit dat we alleen kunnen ingrijpen in het klanklandschap als we op een of andere manier 'toegang' hebben tot de genoemde technologieën. De eigenaar van een winkel bijvoorbeeld, heeft de mogelijkheid om muzak te laten spelen in zijn zaak en een gemeenteraad kan besluiten om een geluidscherm te laten bouwen om een bepaald gebied te beschermen tegen verkeersgeluid. De 'toegangsmogelijkheden' tot de technologieën waarmee het geluid in de omgeving van de mens beïnvloed kan worden, zijn in geval van de genoemde winkeleigenaar en gemeenteraad de eigendomsrechten, beslissingsbevoegdheden en budgetten waarover deze beschikken. Atkinson situeert de mogelijkheden tot ingrijpen in het klanklandschap dus volledig bij de productie van geluid en gaat voorbij aan het feit dat perceptie en betekenis van geluid, en het daarmee verbonden welbevinden en gedrag van mensen, niet universeel en ahistorisch zijn.

Hetzelfde kan gezegd worden van een artikel van Michael Toyka-Seid dat ingaat op "the effect of noise and acoustic pollution on urban societies and the reactions of individuals and of society as a whole to this environmental problem" (Toyka-Seid, 2005 , p. 216). Hoewel de auteur, wiens onderzoek gericht is op de duurzame stad, wijst op problemen rondom het vaststellen van wat "lawaai" is en wat niet, ligt in zijn stuk niettemin de nadruk op het effect van bepaalde geluidsomgevingen op mens en samenleving. Ook in Peter Payers artikel over het geluid en het lawaai in Wenen van 1870 tot aan de Eerste Wereldoorlog, worden veranderingen in het klanklandschap enkel toegeschreven aan aanpassingen in "the way that material structures are arranged and the types of sound produced" (Payer, 2007, p. 774). Hetzelfde geldt voor een artikel van Klaus Saul over de toename van geluid en de opkomst van de antilawaaibeweging in het Duitse keizerrijk (Saul, 1996a). Zowel de stadshistoricus Payer als de sociaalhistoricus Saul onderkennen dat sociale en politieke motieven een rol spelen in het ontstaan van deze anti-lawaai-bewegingen. Desondanks zijn hun publicaties zo opgebouwd dat veranderingen in de aard en materialiteit van geluid een relatief grote autonomie en verklarende kracht hebben. Overigens heb ik dankbaar gebruik gemaakt van de vele voorbeelden van nieuwe en veranderende geluiden die Payer en Saul in hun artikelen noemen. Ze maakten mij alert op de mogelijkheid van soortgelijke ontwikkelingen in de Amsterdamse situatie.

Raymond W. Smilors werk tenslotte, gaat expliciet over lawaai en de antilawaai beweging in America van 1900 tot 1930. Volgens deze historicus was de toename van lawaai als gevolg industrialisering en technologisering een vanzelfsprekend uitgangspunt dat door alle Amerikanen werd gedeeld. "As people became aware of the dangers that noise posed, they reacted, not as members of a particular class or a special interest, but as listeners" (Smilor, 1977, p. 36). Smilor onderkent weliswaar dat de volgens hem wijdverspreide reactie tegen lawaai ook een weerspiegeling is van zorgen 
over maatschappelijke ontwikkelingen, maar desondanks is een universele en ahistorische begrip van lawaai en dito invloed van geluid op de mens zijn uitgangspunt.

Het 'ecologie van geluid' perspectief kan bekritiseerd worden omdat het voorbijgaat aan het gegeven dat de perceptie van geluid, net als alle andere zintuiglijke waarneming, mede bepaald wordt door plaats, tijd en culturele context. Dit laatste is tegenwoordig een vaak gebruikt uitgangspunt, niet alleen als het gaat historische klanklandschappen maar ook op het vlak van de historiografie van de zintuigen in het algemeen (Jay, 2011; Rosenfeld, 2011; Smith, 2007). Wat we desondanks van het ecologisch perspectief kunnen leren en overnemen, is het idee dat geluid meer is dan louter een systeem van afspraken of een sociale praktijk. Tot op zekere hoogte is geluid een verschijnsel dat juist door zijn natuurkundige eigenschappen (trillingen) invloed kan uitoefenen op mensen en hun omgeving (S. Goodman, 2010). Denk maar aan 'mosquitos', apparaatjes die een hoge toon uitzenden die vrijwel alleen door jongeren kan worden gehoord en gebruikt wordt om hen van bepaalde plekken te verdrijven. ${ }^{15}$ Wie geluid en maatschappij wil begrijpen zal dan ook oog moeten hebben voor zowel de materiële eigenschappen als de culturele context van geluid. Voor dit proefschrift is de 'ecologie van geluid' als onderzoeksperspectief echter vooral relevant om te onderzoeken welke geluiden men in bepaalde historische situaties redelijkerwijs gehoord zou kunnen hebben. Pas dan kan immers duidelijk worden welke geluiden wel en niet besproken werden, en wat dat zegt over de maatschappelijke rol van geluid. Anders gezegd: juist door de ecologie van geluid serieus te nemen, krijgen we meer vat op de mate waarin en de manier waarop geluid ertoe deed.

\section{Semiotiek van geluid}

Een vroeg en duidelijk voorbeeld van het tweede perspectief, de 'semiotiek van geluid', is Corbins boek over de betekenis van kerkklokken voor het dagelijks leven op het Franse platteland in de negentiende eeuw (Corbin, 1998). Maar ook Schafers concept 'soundmark', een geluid zoals dat van de Big Ben in Londen dat specifiek verwijst naar een bepaalde locatie, en 'sound signal', dat wil zeggen een geluid waarop de aandacht expliciet wordt gevestigd, suggereren dat men zich binnen diens soundscape project vanaf het begin realiseerde dat geluid binnen een bepaald betekenissysteem geïnterpreteerd wordt (Schafer, 1977/1994, pp. 274-275). Desondanks was er, in dit milieuhistorische onderzoek naar veranderingen in het klanklandschap, nauwelijks aandacht voor het opsporen van verschuivingen in de betekenis van geluid.

\footnotetext{
${ }^{15}$ Sinds eind 2011 is het gebruik van mosquitos in Amsterdam verboden (Het Parool, 22-02-2012 en 24-022012; De Telegraaf, 14-03-2012). Mosquitos zijn echter nog vrij onschuldig in vergelijking met andere toepassingen van geluid die bijvoorbeeld in bezette gebieden en in gevangenissen worden ingezet voor het verdrijven of martelen van mensen (Bain, 2005; Goodman, 2010).
} 
Onder de publicaties over stadsgeluid is Sounds of the city: the soundscape of early modern European towns van historicus David Garrioch het meest illustratieve voorbeeld van de 'semiotiek van geluid' (Garrioch, 2003). Dit artikel beschrijft niet alleen allerlei soorten geluid die te horen waren in vroegmoderne Europese steden, maar maakt ook duidelijk hoe de 'hoorbare' omgeving als een betekenissysteem functioneerde. Klokken, bijvoorbeeld, gaven aan dat de werkdag was begonnen, de stadspoorten waren geopend of dat er brand was in de stad. Trommels of de roep van de nachtwaker werden gebruikt om de avondklok aan te kondigen en aan het geluid van voetstappen in de straat hoorde de stedeling hoe levendig de markt was. Garrioch erkent dat in de vroegmoderne tijd geluid ook op het platteland een rol speelde, maar is van mening dat dit betekenissysteem van geluiden voor het dagelijkse leven in de steden veel belangrijker was. Geluid was een cruciaal onderdeel van het communicatiesysteem van de stad en "formed part of people's way of navigating in time, space and in the social world of the city" (Garrioch, 2003, p. 6). Volgens de schrijver zorgden veranderende politieke en sociale praktijken er voor dat de bruikbaarheid van dit betekenissysteem van geluiden in steden en stadjes voor een steeds groter wordend deel van de bewoners terugliep. Daarmee is niet gezegd dat geluid plotseling alle betekenis verloor, maar wel dat communicatie op basis van geluid, dat volgens Garrioch zo kenmerkend was voor de vroegmoderne Europese stad, geleidelijk verdween.

Garriochs artikel was vanwege de historische invalshoek voor mijn onderzoek handig als een soort van checklist van stadgeluiden uit het verleden. Verder lijkt de conclusie ten aanzien van het teloorgaan van het stedelijk betekenissysteem van geluiden te suggereren dat het geen zin heeft om naar een dergelijk systeem in de moderne stad te zoeken. Er valt inderdaad niet aan te twijfelen dat een deel van het oude systeem voor veel stedelingen zijn betekenis verloren heeft, want hoeveel mensen kunnen bijvoorbeeld de verschillen in het luiden van kerkklokken nog duiden? Bovendien kan een sterke groei van het aantal geluidsbronnen, zoals het aantal autotoeters en fietsbellen in de jaren dertig in Amsterdam, er voor zorgen dat niet langer duidelijk is voor wie een signaal bestemd is. Tenslotte zal een eventuele toename in het geluidsniveau een aantal geluiden maskeren en het corresponderende deel van het systeem teniet doen. Maar dit impliceert niet dat het betekenissysteem volledig is verdwenen of niet zou kunnen veranderen. Alleen al om die reden is het zinvol om te blijven 'luisteren' naar de betekenis in het stadsgeluid. Oude geluiden kunnen een nieuwe betekenis krijgen en bovendien kunnen er elk moment nieuwe betekenisvolle geluiden opduiken.

\section{Politiek van geluid}

Het derde en laatste perspectief, de 'politiek van geluid', is gericht op geluid dat bedoeld of onbedoeld ongenoegen opwekt. Enerzijds kan geluid, niet zelden in de vorm van 'welluidende' muziek, bewust worden geproduceerd om uitdrukking te geven 
aan de identiteit, missie of het protest van een omstreden maatschappelijke groepering of sociale klasse. In Breaking the Sound Barrier geeft Peter Bailey, een sociaal en cultureel historicus geïnteresseerd in de populaire cultuur van Victoriaans Engeland, een beknopt overzicht van de lange geschiedenis van deze vorm van 'herrie maken' (Bailey, 1998/2004, pp. 25-26). Onderstaand citaat uit Het volk: dagblad voor de arbeiderspartij geeft een Nederlands voorbeeld uit 1918 van deze praktijk.

Zondag en Maandag werden te Goor de onafhankelijkheidsfeesten gehouden. Reeds acht dagen te voren was het 's avonds een heel lawaai van oranje-bovenzingers in de straten en brachten de "feestvierenden", (hoofdzakelijk katholieken) serenades bij onze meest vooraanstaande partijgenooten. Dit begon den arbeiders te vervelen. Op den vooravond van het feest trok een optocht van socialistische mannen en vrouwen, luid onze liederen zingend, door de straten, om tegen het gesar tegen onze partijgenooten te protesteeren. Deze betooging maakte zóóveel indruk, dat het er dadelijk kalmer op werd. Met de serenades was het nu gedaan (Het volk: dagblad voor de arbeiderspartij, 3 september 1918, p. 2).

Maar ook in situaties waarin de maker of veroorzaker van een geluid dat helemaal niet nastreeft, kan de waarneming van een geluid ongenoegen opwekken. Bij dit laatste spelen machtsverschillen en processen van sociale distinctie vaak een belangrijke rol. Klachten over geluid hangen bovendien vaak samen met situaties of gebeurtenissen die niet op een politiek correcte of sociaal wenselijke manier rechtstreeks bekritiseerd kunnen worden.

Het perspectief van de 'politiek van geluid' is terug te vinden in publicaties over negentiende en twintigste-eeuwse debatten over geluid. Zoals de volgende voorbeelden laten zien kunnen deze debatten gaan over lawaai in het algemeen of over een heel specifiek geluid. Bijsterveld concludeert dat in antilawaaicampagnes in de twintigste eeuw lawaai werd gezien als "a sign of a deliberate disruption of societal order, often by those lower in the hierarchy. The kind of order thought to be threatened varied over time and over the kinds of people complaining" (Bijsterveld, 2001, p. 60). En in Die Stadt, der Lärm und das Licht: Die Veränderung des öffentlichen Raumes durch Motorisierung und Elektrifizierung, een publicatie voortkomend uit onderzoek naar de ecologische, technische en culturele geschiedenis van Hannover in de vroege twintigste eeuw, beschrijven de auteurs de tegengestelde reacties op het geluid van auto's in relatie tot optimistische en pessimistische tijdsbeelden (Birkefeld \& Jung, 1994, pp. 104-117).

Voor zover het om het debat in een bepaalde stad gaat, is John Pickers The Soundproof Study: Victorian Professionals, Work Space, and Urban Noise (2000) een mooi voorbeeld van deze benadering. Deze auteur, actief op het vlak van literatuur en vergelijkende media studies, laat overtuigend zien dat acties tegen straatmuziek in Londen tijdens de tweede helft van de negentiende eeuw vooral werden gevoerd door 
schrijvers, kunstenaars, filosofen en vergelijkbare professionals wier status als respectabele beroepsgroep nog onzeker was. Zij streefden een maatschappelijke erkenning na die vergelijkbaar was met die van artsen, juristen en militairen en voelden zich in het afbakenen van een dergelijk professioneel territorium gedwarsboomd door het lawaai van straatmuzikanten. Deze verstoorden de rust die ze als respectabele professionals verdienden en nodig hadden voor de uitoefening van hun beroep (Picker, 2000).

\section{Toepassing van de drie perspectieven}

Voorafgaand aan de bespreking van de perspectieven in samenhang met de literatuur waarvan ze zijn afgeleid, is al naar voren gebracht dat het de voorkeur verdient om de ze systematisch en naast elkaar te gebruiken. Nu de perspectieven in detail zijn toegelicht, wil ik dat opnieuw benadrukken. Systematische en gecombineerde toepassing van de drie perspectieven maakt het mogelijk om nieuwe vragen te beantwoorden. Een onderzoek naar de ecologie van geluid dat samengaat met een besef van de culturele dimensie van dat geluid, vergroot het inzicht in de wijze waarop dat culturele aspect in een bepaalde historische situatie tot uitdrukking komt. Juist een zo volledig mogelijk overzicht van de geluiden die in een bepaalde plaats en tijd geproduceerd worden is nodig om de geluiden waarover wel en niet wordt gesproken en geschreven te kunnen identificeren. En informatie over de betekenis van geluiden en veranderingen daarin, kan zicht geven op de redenen waarom in die plaatsen en perioden ophef ontstaat over bepaalde geluiden.

\section{Methoden en bronnen}

\section{Het discours over geluid}

In deze dissertatie wordt naar het verleden 'geluisterd' op basis van teksten waarin inwoners en in een aantal gevallen ook bezoekers van Amsterdam, schrijven over de geluiden die ze horen, welke betekenis die geluiden voor hen hebben, wat ze er van vinden en wat er naar hun oordeel eventueel met die geluiden of hun oorzaak gebeuren moet. ${ }^{16}$ Dit 'luisteren' naar stadsgeluid uit het verleden betekent in feite het luisteren naar en analyseren van het discours over dat geluid, waarbij het begrip 'discours' gedefinieerd kan worden als het ensemble van ideeën, concepten en categorieën dat in bepaalde praktijken wordt gebruikt om betekenis te geven aan materiële

\footnotetext{
${ }^{16}$ Een klein deel van deze teksten bestaat uit fragmenten uit verslagen van gemeenteraads-vergaderingen. In deze gevallen zijn de teksten een schriftelijke weergave (door de verslaglegger) van de uitspraken van woordvoerders.
} 
en sociale realiteiten. Discours analyse kan helpen bij het vinden van redenen waarom bepaalde visies op en definities van de sociale en materiële realiteit in de ene context wel gehoor vinden en in de andere niet (Hajer \& Versteeg, 2005, pp. 175-178).

In Maarten Hayers onderzoek naar de politieke dimensie van milieuvraagstukken aan het einde van de twintigste eeuw, wordt discours analyse vooral toegepast om de positie van diverse actorgroepen in een bepaald debat te kunnen verklaren (Hajer, 1995). In dit onderzoek gaat het echter om veranderingen in het discours over stadsgeluid in Amsterdam over een langere periode en daarom is het van belang zicht te krijgen op het dominante discours van elke afzonderlijk tijdvak. Met behulp van de perspectieven komen we te weten welke geluiden aandacht krijgen en eventueel omstreden zijn in een bepaald tijdvak en welke betekenis aan geluiden wordt toegekend. Teneinde te kunnen verklaren waarom dat zo is, is het verder nodig om per periode te analyseren hoe stadsgeluid en het oordeel daarover in teksten tot uitdrukking wordt gebracht. Daarbij gaat het om de woorden, vergelijkingen, metaforen en concepten die veelvuldig worden gebruikt, het medium waarvan de tekst onderdeel uitmaakt en de culturele en sociale praktijk waarin deze media een rol spelen. Want de reden waarom een bepaalde opmerking gehoor vindt, is niet alleen afhankelijk van de plausibiliteit van de gevolgde redenering maar ook van het vertrouwen dat het publiek heeft in zowel de auteur of spreker als de praktijk waarbinnen deze zijn of haar uitspraak doet (Hajer, 1995, p. 63).

Voor de analyse van het Amsterdamse discours over stadsgeluid in verschillende periodes zijn teksten nodig waarin het actuele en dagelijkse geluid van de stad aan de orde komt. Om zicht te krijgen op het meest gangbare discours in een specifiek tijdvak, gaat het bij voorkeur om teksten die geproduceerd zijn door of voor een zo groot mogelijk deel van de Amsterdamse bevolking. Verder moeten ze geschreven en gepubliceerd zijn in de tijd waarop ze betrekking hebben en behoren tot de categorie non-fictie. In principe kunnen de primaire bronnen die hier zijn geraadpleegd in drie categorieën worden onderverdeeld: krantenartikelen, verslagen (gepubliceerd en ongepubliceerd) van het dagelijks leven in de stad en documenten uit het archief van de gemeente Amsterdam.

Kranten zullen relatief gezien het grootste deel van de bevolking bereiken en aan de productiezijde zullen schrijvers van brieven en dagboeken de grootste variatie aan bewoners vertegenwoordigen. De gebruikte krantenartikelen bestaan grotendeels uit verslaggeving, columns en ingezonden brieven. Relatief gezien biedt deze categorie bronnen zowel qua bereik als qua herkomst de grootste kans op een evenredige afspiegeling van de opinie van de bewoners van Amsterdam. De verslagen over het leven in de stad omvatten memoires van Amsterdammers (waaronder oorlogsdagboeken) en reisverslagen van buitenlanders die Amsterdam bezoeken. De stukken uit het archief van de gemeente betreffen verslaglegging van raadsverslagen, interne memo's, processen verbaal en klachtenbrieven. De bronnen die behoren tot de beide laatste categorieën vertonen op het gebied van bereik en herkomst een mix. De 
Amsterdamse dagboekauteurs vertegenwoordigen de visie van de 'gemiddelde' Amsterdammer uiteraard veel beter dan de buitenlandse bezoekers, maar ongepubliceerde dagboeken bereiken het lezerspubliek niet terwijl de reisverslagen wel vrij snel werden vertaald en gelezen. Het 'bereik' van de genoemde documenten uit het archief van de gemeente is in theorie groot maar in de praktijk vrij beperkt. Ze zijn openbaar toegankelijk, maar wie krijgt ze echt onder ogen? Daar staat weer tegenover dat in processen verbaal en klachtenbrieven de visie en het taalgebruik van een relatief gevarieerd deel van de bevolking zijn vastgelegd. Verderop in dit hoofdstuk en in de empirische hoofdstukken, zal bij de bespreking van specifieke bronnen meer in detail worden ingegaan op de veronderstelde visie en/of maatschappelijke positie van het lezerspubliek en de auteurs.

In een aantal gevallen is van het uitgangspunt om enkel teksten te gebruiken die geschreven zijn in de periode waarop ze betrekking hebben afgeweken en is er gebruik gemaakt van herinneringen aan de betreffende periode. Het gaat daarbij om herinneringen aan het leven in Amsterdam gedurende het einde van de negentiende eeuw en herinneringen aan (Joods) Amsterdam vóór het uitbreken van de Tweede Wereldoorlog. In die situaties hebben deze bronnen enkel een rol gespeeld bij het verzamelen van informatie over geluiden die geproduceerd werden. Welke bronnen dit zijn wordt in de betreffende hoofdstukken expliciet aangegeven. Daarnaast zijn voor gegevens over de productie van geluiden secundaire bronnen geraadpleegd die zicht geven op activiteiten en gebeurtenissen in de stad, de frequentie waarin deze gedurende de onderzochte periode plaatsvonden, de locatie van die activiteiten, de intensiteit en de aard van verkeersstromen en de materialiteit van omgeving en objecten. Voor de casus over de negentiende eeuw is daarbij ook gebruik gemaakt van foto's van Jacob Olie (Olie, 2007). Bijvoorbeeld om na te gaan welk soort schoeisel gedragen werd en welk soort nijverheid op straat werd beoefend.

Teksten over geluid zijn meestal niet meer dan korte fragmenten, omdat het zowel vroeger als tegenwoordig niet zo heel gebruikelijk was en is om bij het weergeven van situaties en gebeurtenissen over geluid te schrijven. Dit laatste zorgt er ook voor dat verwijzingen naar deze tekstfragmenten zelden te vinden zijn in handmatig gecreëerde indexen en vergelijkbare hulpmiddelen voor het ontsluiten van documenten en verzamelingen. Het opsporen van bruikbaar materiaal is daarom zeer arbeidsintensief. Gelukkig biedt de digitalisering van teksten en de bijbehorende mogelijkheden om grote hoeveelheden tekst op woordniveau te doorzoeken hier uitkomst. Een andere gelukkige omstandigheid is het feit dat de Koninklijke Bibliotheek (KB) in 2008 een project is gestart om Nederlandse dagbladen uit de zeventiende tot en met de twintigste eeuw te digitaliseren en online beschikbaar te stellen. ${ }^{17}$ De combinatie van de beschikbaarheid in digitale vorm, de relatief continue aanwezigheid van kranten in de bestudeerde perioden, en het feit dat krantenartikelen qua herkomst en bereik de

\footnotetext{
${ }^{17}$ Zie website http://kranten.kb.nl/.
} 
grootste kans bieden op weerspiegeling van 'de' stem van de Amsterdamse bevolking, zorgen ervoor dat deze categorie bronnen in dit onderzoek een centrale plaats inneemt. Vanwege het feit dat de databank met historische kranten van de KB tijdens het onderzoek in opbouw was en zelfs van zogenaamde 'beschikbare' krantentitels nog lang niet alle jaargangen bevatte - ik kom hier nog op terug - bleef de oogst aan teksten over geluid echter beperkt. Om die reden is naast het KB archief ook gebruik gemaakt van de eigen digitale historische archieven van Het Parool (1940-1945), Leeuwarder Courant (met name een column over Amsterdam) en het weekblad De Groene Amsterdammer en bovendien van niet-gedigitaliseerde krantenartikelen in de 'Persdocumentatie' en het 'Archief van de Politie' van Stadsarchief Amsterdam. ${ }^{18}$ Verder vormen de eerder genoemde andersoortige bronnen, zoals verslagen (gepubliceerd en ongepubliceerd) van het dagelijks leven in de stad en documenten uit het archief van de gemeente Amsterdam, ook een onmisbare aanvulling.

\section{Digitale historische verzamelingen}

Alvorens per casus dieper in te gaan op de bronnen die zijn gebruikt en op de vraag in hoeverre de 'stemmen' die we daarin horen representatief zijn voor de Amsterdamse bevolking van die tijd, wil ik even stilstaan bij de mogelijkheden en beperkingen van de genoemde digitale historische verzamelingen. Met uitzondering van het online archief van Het Parool uit de Tweede Wereldoorlog, zijn alle genoemde verzamelingen opgebouwd uit gescande pagina's die met behulp van OCR-software (Optical Character Recognition) zijn omgezet naar digitale tekst. Deze digitale tekst kan vervolgens met woorden, delen van woorden of combinaties van woorden volledig worden doorzocht. ${ }^{19}$ Daardoor is het onder andere mogelijk om tekstfragmenten op te sporen over onderwerpen die zelden of nooit in indexen of andere ontsluitingshulpmiddelen te vinden zijn.

Er zijn echter ook problemen verbonden aan deze werkwijze. In de eerst plaats kunnen oneffenheden of vlekken op de originele pagina's, slecht drukwerk, een complex lettertype en andere onregelmatigheden er voor zorgen dat de OCR-software een woord niet of niet juist herkent. Als het woord niet wordt herkend, zal de betreffende

\footnotetext{
${ }^{18}$ In 'Persdocumentatie Collectie Stadsarchief Amsterdam' (toegangsnummer 30486) zijn krantenknipsels over een breed scala aan Amsterdamse onderwerpen uit lokale, regionale en landelijke dagbladen opgenomen uit de periode 1915-1997. De knipselverzameling is niet ontsloten met behulp van het trefwoord 'geluid' of 'lawaai' maar wel met de trefwoorden 'geluidsoverlast' en 'verkeerslawaai' (beide aangeduid met categorienummer 938). Over het tijdvak 1918-1940 is er echter geen enkel artikel onder deze trefwoorden in de verzameling te vinden. Om die reden heb ik de knipselverzameling doorzocht met behulp van de trefwoorden 'verkeer' (nummers 194-199), 'straathandel en venters' (nummers 222-228), 'straatartiesten, straatmuzikanten en straatzangers' (nummer 930).

${ }^{19}$ De digitale tekst kan in feite met elke willekeurige reeks van tekens worden doorzocht. Daarnaast kan ook gebruik worden gemaakt van regels ontleend aan de verzamelingenleer om bepaalde deelverzamelingen te combineren of uit te sluiten.
} 
tekst niet via dat woord worden gevonden. Wordt het woord niet juist herkend, dan is het betreffende tekstfragment niet wat men zoekt. Uit een meting van de KB in 2004 op basis van een steekproef van kranten bleek dat $27 \%$ tot $52 \%$ van de woorden onjuist werd weergegeven. In een meer recent onderzoek naar een krantenarchief van de British Library bleek 22\% van de woorden niet correct te zijn vertaald door de OCRsoftware (Klijn, 2011, p. 59). De situatie lijkt dus wel te verbeteren, maar desondanks is de kans op foutieve omzetting van woorden nog steeds vrij groot. Deze beperking van de OCR-software en de slechte staat van de nog beschikbare papieren versies van Het Parool uit de periode 1940-1945 hebben er dan ook voor gezorgd dat dit digitale archief enkel op het niveau van koppen en met behulp van een beperkt aantal trefwoorden kan worden doorzocht (Stichting Democratie en Media, n.d.).

Het tweede probleem van het op digitale wijze doorzoeken van grote hoeveelheden teksten komt voort uit het feit dat de betekenis van een woord in sterke mate door de overige tekst wordt bepaald. Het digitale zoekproces is echter uitsluitend gebaseerd op een precieze reeks van tekens. Dit betekent in de eerst plaats dat spellingsvarianten, 'gedruisch' in plaats van 'gedruis' bijvoorbeeld, niet worden herkend. Bovendien levert het zoeken met één woord relatief veel resultaten op die niet bruikbaar zijn, omdat het betreffende woord een betekenis heeft of in een context wordt gebruikt dat in het kader van het betreffende onderzoek niet relevant is. Een voorbeeld: zoeken met het woord 'lawaai' in het digitale archief van de Leeuwarder Courant over de periode 1860 tot 1899 levert 153 artikelen op. In deze artikelen komt het woord 'lawaai' meestal maar één keer voor. Bij feuilletons, $\pm 20 \%$ van de artikelen (en omdat het om fictie gaat voor mijn onderzoek niet relevant), wordt het woord vaak gebruikt om een situatie of sfeer te beschrijven. Bij artikelen over rechtszaken, ongeveer $22 \%$ van het totaal en betrekking hebbend op inbraken, geweldmisdrijven en dronkenschap, wordt geregeld vermeld dat de verdachte lawaai maakte of dat getuigen door lawaai werden gealarmeerd. In beschouwingen over buitenlands nieuws, ongeveer $20 \%$ en vaak beschrijvingen van politieke kwesties, wordt 'lawaai maken' gebruikt voor wat wij tegenwoordig 'ophef maken' of 'protesteren' noemen. Van de 153 gevonden artikelen waarin het woord 'lawaai' voorkomt, gaat het slechts in 10 gevallen om een gebruik van het woord in verband met het begrip stadsgeluid dat in dit onderzoek wordt gehanteerd. In het voorbeeld is dus niet meer dan 6,5\% van de gevonden artikelen relevant. Zoals we later nog zullen zien, komt het percentage van relevante artikelen over de periode 1875-1895 binnen het totaal van alle gevonden artikelen over die periode zelfs niet boven de 4,5\%. Het kan in dit soort situaties, waarin een woord op veel verschillende manieren wordt gebruikt, helpen om de zoekactie specifieker te maken door meerdere relevante zoekwoorden te gebruiken. Dat vermindert de kans op onbruikbare treffers, maar kan helaas ook betekenen dat 
bruikbaar materiaal dat niet aan het specifiekere zoekargument voldoet niet gevonden wordt. $^{20}$

Het zoeken met woorden in een digitale verzameling van kranten legt het taalkundig en thematisch verband tussen de gevonden teksten bloot, maar tilt deze teksten tegelijkertijd uit de context van de overige artikelen die op hetzelfde moment in de betreffende kranten verschenen zijn (Broersma, 2011, pp. 41-42). Dat vormt voor dit onderzoek echter niet zo'n bezwaar omdat het hier gaat om het discours over geluid in een bepaalde periode, dat wil zeggen over de manier waarop over geluid wordt geschreven.

Naast deze meer algemene problemen rondom het gebruik van digitale historische archieven, waren, alweer met uitzondering van Het Parool, geen van de gebruikte digitale verzamelingen tijdens dit onderzoek volledig beschikbaar of in hun definitieve vorm. ${ }^{21}$ Veranderingen van 'vorm', in dit geval zowel in de manier waarop in de verzameling kan worden gezocht als van het formaat waarin resultaten worden aangeboden, hebben plaatsgevonden bij de Leeuwarder Courant en De Groene Amsterdammer. Dit soort veranderingen hindert vooral het op één en dezelfde manier doorzoeken van een verzameling over een langere periode en het systematisch verwerken van resultaten, maar daar is een mouw aan te passen. De beperkte beschikbaarheid van de digitale krantenverzameling van de KB heeft er echter voor gezorgd dat zoekacties slechts een beperkt aantal bruikbare resultaten opleverden. Met gebrek aan beschikbaarheid wordt dan vooral gedoeld op het feit dat niet alleen het aantal opgenomen krantentitels nog vrij beperkt was, maar dat bovendien niet aangegeven kon worden wanneer welke jaargangen van de opgenomen titels beschikbaar zouden zijn. Weliswaar was vanaf het begin van het project bekend dat gestart zou worden met de jaargangen 1829-1919 van het Algemeen Handelsblad en dat dit later uitgebreid zou worden met alle jaargangen tot 1940 . Desondanks bleek na nauwkeurige analyse van zoekresultaten medio 2010, dat de digitale verzameling enkel kranten uit de jaargangen 1875, 1880, 1889, 1891, 1894 en 1895 bevatte. Omdat het scannings- en digitaliseringsproces qua volgorde niet werd gestuurd door enige chronologische ordening, bleek het niet mogelijk om op voorhand aan te geven welke jaargangen opgenomen waren in de databank. ${ }^{22}$

\footnotetext{
${ }^{20}$ Het boekje Eerste Hulp bij e-Onderzoek van Ewoud Sanders (Sanders, 2011), een initiatief van de universiteitsbibliotheken Leiden en Amsterdam en van de KB, biedt handige tips en trucs voor het werken met digitale bronnen. Zie ook (Broersma, 2011).

${ }^{21}$ In de inleiding tot het themanummer 'Het digitale verleden en de toekomst van de mediageschiedenis' van het Tijdschrift voor Mediageschiedenis vermeldt Marcel Broersma dat er voor het digitaliseren van oude bronnen ongeveer net zoveel standaarden en specificaties zijn gebruikt als er projecten zijn. "Daardoor wordt het, ook in de toekomst, onmogelijk om bestanden te koppelen en als één geheel te doorzoeken" (Broersma, 2001).

${ }^{22}$ Emailbericht van Edwin Klijn, projectleider KB d.d. 22 juli 2010.

Verder bleek ook het inzicht in en de informatieverstrekking over de mogelijkheden en beperkingen van de software die wordt gebruikt om de databank te doorzoeken nog met kinderziektes te kampen. Bij het
} 
De combinatie van voornoemde tijdelijke en blijvende voor- en nadelen van de digitale historische krantenverzamelingen heeft mij ertoe gebracht om bij het zoeken van artikelen over het geluid in Amsterdam ook teksten te selecteren over geluid in bredere zin. Het is immers aannemelijk dat het discours over het geluid in de stad ook mede bepaald wordt door de wijze waarop men over geluid in andere situaties of in het algemeen denkt, spreekt en schrijft. Dit heeft ertoe geleid dat ik naast de artikelen over geluid in Amsterdam, ook teksten heb verzameld over geluid in andere steden, over apparaten waarin geluid op een of ander manier een rol speelt, over geluid als publiek communicatiemiddel (gebruik van trommen en klokken), over geluid als natuurkundig fenomeen (akoestiek) en over geluid als 'bijproduct' van mensen en dingen. De volgende grafiek geeft per categorie het aantal artikelen weer dat gebruikt is voor de casus over het einde van de negentiende eeuw. Daarbij is ook de verhouding afgebeeld tussen het totale aantal artikelen dat voor de betreffende periode uit de databank is geselecteerd en verwerkt en het aantal relevante teksten.

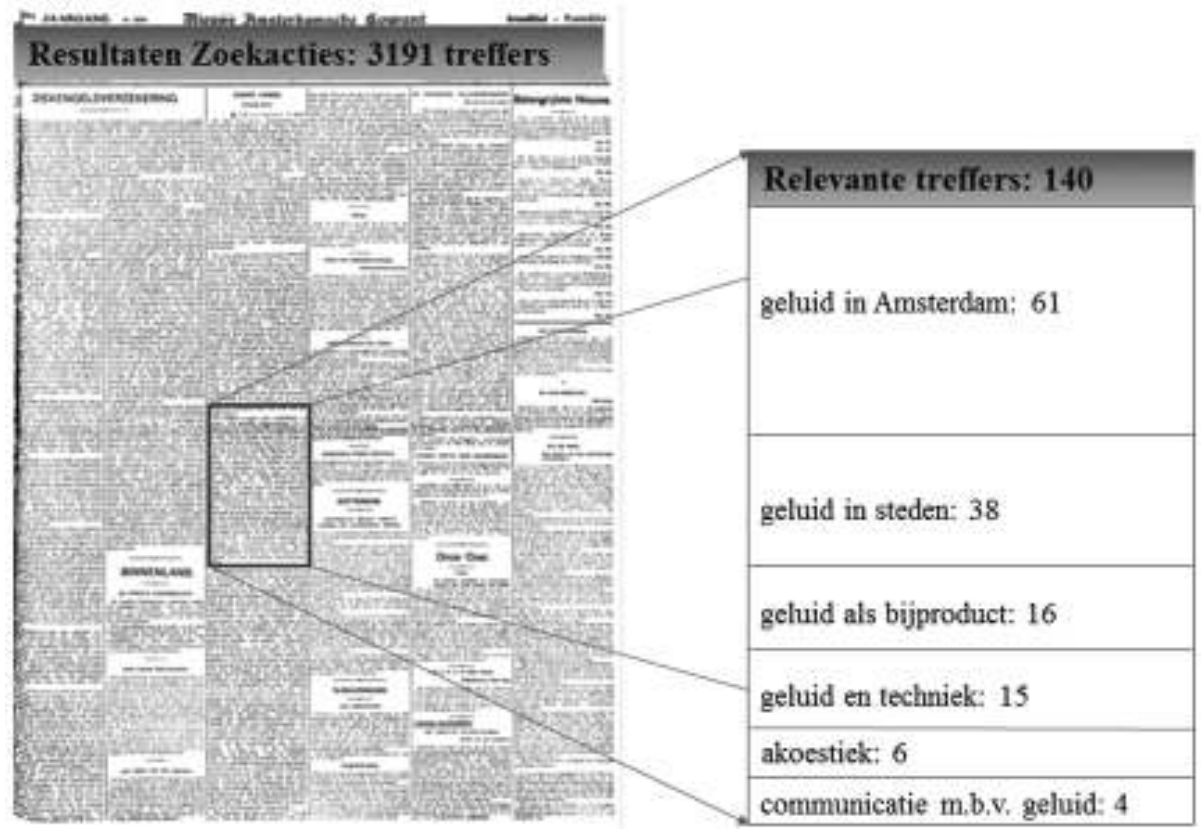

Afbeelding 1: Artikelen uit de periode 1875-1895

vergelijken van resultaten van zoekopdrachten ontdekte ik dat de software geen haakjes herkent in de zoekopdracht. Dit was niet bij de KB bekend. Als gevolg van deze tekortkoming is de volgorde van de parameters in de zoekopdracht cruciaal voor de uitkomst. (Emailbericht van Martijn van Wensveen, helpdesk KB d.d. 21 oktober 2011). 
Bij de selectie van kranten voor dit onderzoek is rekening gehouden met een mix van factoren. Naast de beschikbaarheid in digitale vorm van zoveel mogelijk jaargangen binnen de te onderzoeken tijdvakken, is ook de kans op artikelen over Amsterdam en de mate waarin de betreffende krant in de stad gelezen werd van belang. Verder is gestreefd naar een selectie van kranten die de contemporaine visie en 'stem' van een zo breed mogelijk deel van de bevolking zou weerspiegelen. Bij de start van het onderzoek waren de keuzemogelijkheden beperkt tot de volgende kranten:

\begin{tabular}{ll}
\hline & $\begin{array}{l}\text { periode in databank } \\
\text { (in principe) }\end{array}$ \\
\hline Via website Historische Kranten (KB) & $1829-1919$ (t.z.t. tot 1940) \\
Algemeen Handelsblad (Amsterdam) & $1872-1889$ (t.z.t tot 1959) \\
De Tijd: godsdienstig-staatkundig dagblad (katholiek) & $1870-1914^{23}$ \\
Het nieuws van den dag: kleine courant (Amsterdam) & $1910-1920$ (t.z.t. tot 1945) \\
Het Volk (sociaal democratisch) & $1919-1939$ (t.z.t. tot 1945) \\
Het Vaderland: staat- en letterkundig nieuwsblad (Den Haag) & $1844-1930$ (t.z.t 1969) \\
Nieuwe Rotterdamsche Courant & $1910-1930$ \\
Het Centrum: Dagblad voor Utrecht en Nederland & \\
Via diverse (eigen) websites & $1877-1940$ \\
De Groene Amsterdammer (weekblad) & $1940-1945$ \\
Het Parool & $1752-h e d e n$ \\
Leeuwarder Courant & \\
\hline
\end{tabular}

Dag- en weekbladen die niet in digitale vorm beschikbaar zijn, maar wel gedurende de onderzoeksperiode van betekenis waren in Amsterdam, zijn: het dagblad De Amsterdammer (1883-1894, gelieerd aan De Groene Amsterdammer), De Amsterdamsche Courant (1618-1903, daarna opgegaan in De Telegraaf, werd 'het geeltje' genoemd), De Telegraaf (opgericht in 1893) en De Standaard (1872-1944, anti revolutionair dagblad opgericht door Abraham Kuyper).

Voorgaand overzicht laat zien dat er weinig dag- en weekbladen zijn die over een langere periode in digitale vorm beschikbaar zijn en bovendien een relatie hebben met Amsterdam. Het gegeven dat enkel het Algemeen Handelsblad en De Groene Amsterdammer over twee van de drie te onderzoeken periodes in principe digitaal beschikbaar zijn, een band hebben met Amsterdam en over een relatief grote lezerskring

\footnotetext{
${ }^{23}$ Heeft bestaan tot 1923, is toen overgegaan in De Courant: het nieuws van de dag (later De Telegraaf).
} 
beschikten, zorgt er voor dat deze media belangrijke bronnen zijn voor dit onderzoek. Deze selectie is verder voor elk afzonderlijk tijdvak aangevuld met andere kranten die op dat moment van betekenis waren voor Amsterdam.

\section{Casus 1875-1895}

Voor het onderzoek naar de periode 1875 - 1895 speelt naast het Algemeen Handelsblad ook Het nieuws van den dag: kleine courant een belangrijke rol. Beide kranten hadden hun basis in Amsterdam en de jaargangen van de onderzoeksperiode waren, althans in principe, in de databank aanwezig. De eerst genoemde krant behoorde aan het einde van de negentiende eeuw, samen met de Nieuwe Rotterdamsche Courant, tot de belangrijkste Nederlandse dagbladen. De krant was in 1828 in Amsterdam opgericht en nam een liberaal standpunt in maar was niet gelieerd aan een politieke partij (Schneider, 1943, pp. 142, 158-159). Ze werd vooral in handelskringen gelezen (Rooy, 2006b, p. 492). De oplage van 9.000 stuks in 1882 steeg tot 13.500 in 1902 . Het nieuws van den dag: kleine courant, de eerste in heel Nederland gelezen massakrant, groeide qua oplage van 31.805 in 1882 tot 37.000 in 1893 (Plasse \& Verbei, 2005, pp. $128,192) .{ }^{24}$ Het was een goedkoop dagblad, met een liberale inslag, dat als krant van de kleinere 'gezeten' burgerij een groot succes was (Rooy, 2006b, p. 492; Schneider, 1943, p. 163). ${ }^{25}$

Het weekblad De Groene Amsterdammer had in 1882 een oplage van 4.000 die toenam tot 6.250 in 1907 (Plasse \& Verbei, 2005, pp. 192, 290). Het was een typisch 'familieblad' voor dat deel van de burgerij dat zich in cultureel en maatschappelijk opzicht als voorzichtig vooruitstrevend beschouwde. Het bood voor elk wat wils (Hartmans, 2002, p. 22). Voor de periode 1875-1895 zijn er in de databank van De Groene Amsterdammer echter geen relevante artikelen gevonden. Dit zou kunnen samenhangen met het feit dat de gescande pagina's van die periode heel moeilijk leesbaar zijn. ${ }^{26}$

De krantenartikelen over geluid uit de periode 1875-1895 zijn verder aangevuld met tekstfragmenten afkomstig van reisverslagen van buitenlandse bezoekers en uit beschrijvingen van het stadsleven (of herinneringen daaraan) door Amsterdammers. ${ }^{27}$

\footnotetext{
${ }^{24}$ Alle cijfers hebben betrekking op de totale oplage van de krant.

${ }^{25}$ Ter vergelijking: het katholieke dagblad De Tijd groeide qua oplage van 2.000 in 1882 tot 4.300 in 1911 ; het anti revolutionaire De Standaard van 2.500 in 1882 tot 3.700 in 1911 en De Telegraaf van 2.000 in 1893 tot 20.427 in 1911.

${ }^{26}$ Van de in totaal 140 artikelen, zijn er 83 afkomstig uit het Algemeen Handelsblad en 57 uit Het nieuws van den dag: kleine courant. Detailinformatie over de wijze van verzamelen is opgenomen in het hoofdstuk over de periode $1875-1895$.

${ }^{27}$ De reisverslagen zijn geschreven door de Italiaan Edmondo de Amici, de Portugees Ramalho Ortigão, de Brit Charles Wood, de Fransman Henry Havard en de Belg Charles de Coster. De negentiende-eeuwse beschrijvingen van het stadsleven in Amsterdam zijn afkomstig van Justus van Maurik en van een anonieme 'Amsterdammer'.
} 
De overige primaire bronnen die zijn geraadpleegd, zijn interne memo's, processen verbaal en klachtenbrieven uit de archieven van de 'Dienst der Publieke Werken' en de 'Secretarie Dienst der Publieke Werken' van Amsterdam. ${ }^{28}$

In de door de gemeente geproduceerde stukken horen we de stem van de gezagsdragers. ${ }^{29}$ Brieven en andere op persoonlijke titel geschreven teksten zijn minstens geschreven door een schoolmeester of een 'klerk', de reis- en stadsverhalen door mannen met literaire aspiraties en de krantenartikelen en columns door journalisten. Tussen de laatste twee soorten schrijvers is er bovendien vaak sprake van overlap; journalisten schrijven ook geregeld boeken en auteurs van reisverhalen en memoires maken stukken voor kranten of weekbladen. Zo was Justus van Maurik, de succesvolle chroniqueur van het Amsterdamse straatleven, sinds 1885 redacteur en medeeigenaar van De Groene Amsterdammer (Hartmans, 2002, p. 25). Het voorgaande houdt in dat van het perspectief van vrouwen, kinderen, arbeiders en armlastigen niet veel bekend is. ${ }^{30}$ We hebben hier dus vooral met de stem te maken van het weliswaar beperkte maar desondanks gezaghebbende deel van de bevolking via de onderwerpen die in zwang zijn en het taalgebruik van hun tijd. En voor zover het stukken uit de krant betreft, is dit ook de stem die in handelskringen en in de top en middenlagen van de burgerij wordt gehoord. ${ }^{31}$

\section{Casus $1918-1940$}

In het interbellum breidt de groep van schrijvers zich enigszins uit. De gepubliceerde beschrijvingen van het stadsleven zijn, met uitzondering van het proefschrift van Veronica Huberts uit 1940 over de Amsterdamse venters, echter nog steeds afkomstig van mannen. ${ }^{32}$ Onder hen bevinden zich wethouders, sociografen, roman- en toneelschrijvers en journalisten. Ruim de helft van deze schrijvers heeft zijn wortels in het arbeiders milieu en/of is van Joodse afkomst. Ook sprekers in raadsvergaderingen en journalisten behoren op zijn minst tot de Amsterdamse middenklasse en zijn boven-

\footnotetext{
${ }^{28}$ Detailgegevens over deze archieven zijn opgenomen in het hoofdstuk over de periode 1875-1895.

${ }^{29}$ Deze gezagsdragers zijn gekozen door een zeer beperkt deel van de bevolking. In 1870 en 1880 is 1,5\% respectievelijk $1,4 \%$ van de totale bevolking kiesgerechtigd, dat is in beide gevallen iets meer dan $6 \%$ van de mannen boven de 23 jaar. In 1890 heeft nog altijd ruim 95\% van de totale bevolking geen stem. (Vries, 1986, p. 20).

${ }^{30}$ De enige uitzondering hierop zijn de herinneringen aan de kindertijd van Salomon Rodriques de Miranda, die opgroeide in het arbeidersmilieu (diamantslijpers) en het later tot vakbondsman en wethouder bracht.

${ }^{31}$ Volgens de Volks- en beroepentelling van 1889 behoorden $62 \%$ van de Amsterdamse mannelijke beroepsbevolking tot de arbeidersklasse, $5 \%$ tot het toezichthoudend en administratief personeel, $14 \%$ tot de vrije beroepen, $3 \%$ tot de ondernemers voor rekening van een ander en $17 \%$ tot de zelfstandige ondernemers en bedrijfshoofden (Anoniem, 1887/1981/2008, p. XX).

32 Het betreft de volgende publicaties: (Bregstein \& Bloemgarten, 2004; Dekker, 1937; Dijkhuis, 1939; Huberts, 1940; Jong, ca. 1920; Polak \& Vlugt, 1936; Presser, 1974; Rodrigues de Miranda, 1921; Sluyser \& Drees, 1957).
} 
dien meestal van het mannelijk geslacht. Het belangrijkst verschil ten opzichte van de negentiende eeuw is dat in het interbellum ook vrouwen en geschoolde arbeiders hun mening kenbaar maken via brieven die in de dagbladen, meer of minder geredigeerd, worden gepubliceerd.

Omdat deze ingezonden brieven doorgaans volledig geanonimiseerd worden gepubliceerd is dit laatste alleen via een omweg af te leiden. Ik gebruik daarvoor informatie over het lees- en schrijfgedrag van ongeschoolde arbeiders in die tijd en gegevens over auteurs van klachtenbrieven uit Groningen. Om te beginnen laten observaties van de sociograaf Henk Dijkhuis uit de tweede helft van de jaren dertig in de Jordaan zien dat lezen en schrijven geen vanzelfsprekendheid is onder ongeschoolde arbeiders en hun gezinnen. De krant (de Courant, het volksblad van De Telegraaf) wordt weliswaar gelezen maar zeer beperkt. "Allen zijn geïnteresseerd bij de moorden en liefdesdrama's met vele pikante details - grote ongelukken, verkrachtingen, rechtzaken en kleinigheden uit de directe omgeving en advertenties." Bovendien is niet iedereen in staat om zelfs maar een boekpagina helemaal te lezen (Dijkhuis, 1939, p. 47). Dit beeld stemt overeen met de conclusie uit een studie naar analfabetisme dat de curve van functioneel analfabetisme in de werkende bevolking de grafiek van de armoede op de voet volgt. In Nederland is vanaf 1901 een leerplichtwet van kracht, maar voor kinderen uit arme gezinnen geldt: "for the most part, it was their bodies rather than their minds that went to school" (Vincent, 2000, pp. 62,67). Het is dus niet waarschijnlijk dat de groep van ongeschoolde arbeiders en armlastigen brieven schrijft aan de krant.

Verder blijkt uit een analyse van brieven van Groningse stadsbewoners uit 1936 gericht aan het 'Anti-lawaai comité Groningen' dat de meerderheid van de schrijvers en schrijfsters goed geschoolde arbeiders zijn of tot de Groningse burgerij of elite behoren. Het archief bevat een verzameling van 109 brieven uit de periode januari april 1936 in reactie op een artikel getiteld 'Groningen lawaaistad?' in lokale kranten. In het bewuste artikel werd gevraagd hinderlijk lawaai te noemen. De taalvaardigheid doet vermoeden dat de ruime meerderheid geregeld schrijft. lets meer dan de helft van de brieven in dat archief zijn eenduidig toe te schrijven aan een man (38) of vrouw (22). Verder zijn er relatief veel reacties van de (medische) elite (artsen, ingenieurs, advocaten, waarvan 16 man en 2 vrouw). ${ }^{33}$ Dit geeft reden om te veronderstellen dat ook de Amsterdamse schrijvers van brieven tot de groep goed geschoolde arbeiders, burgerij of elite behoren en bovendien dat we nu ook de stem van vrouwen horen, zij het enkel uit de laatste twee maatschappelijke categorieën.

Net zoals dat het geval was voor de casus 1875-1895 zijn ook de meeste krantenartikelen uit het interbellum afkomstig van het Algemeen Handelsblad (in totaal 79 artikelen). De oplage van dit dagblad groeide van 36.000 in 1918 tot ruim 46.000 in

\footnotetext{
${ }^{33}$ Archief Anti-lawaai comité Groningen, map 'Brieven op Persberichten' 1935-1937; beschikbaar gesteld door Hero Wit en in het bezit van Maastricht University, Faculty of Arts \& Social Sciences.
} 
1939 (Plasse \& Verbei, 2005, p. 192). Omdat de laatste editie van Het nieuws van den dag: kleine courant op 5 mei 1923 is verschenen en de databank Historische Kranten medio 2010 geen edities van 1915 of later bevatte, is deze krant in de selectie voor deze periode niet meer meegenomen. Wel is er gebruik gemaakt van 24 artikelen uit het weekblad De Groene Amsterdammer, dat een oplage kende van ruim 10.000 in de jaren dertig. Het lezerspubliek van De Groene is gedurende het interbellum vooral te vinden in dat deel van de burgerij dat geen of nog slechts zwakke kerkelijke banden heeft en dat doorgaans liberaal georiënteerd is, al zijn er onder de abonnees ook genoeg sociaaldemocratische intellectuelen te vinden (Hartmans, 2002, pp. 73-83; Plasse \& Verbei, 2005, p. 290). Tenslotte zijn artikelen uit de dagbladen De Telegraaf, Het Vaderland en de Leeuwarder Courant (respectievelijk 13, 10 en 3 artikelen) geraadpleegd. ${ }^{34}$ Van de twee laatstgenoemde dagbladen gaat het daarbij enkel over artikelen over 'geluid in Amsterdam'. ${ }^{35}$ De in totaal 129 artikelen uit het interbellum waarop de analyse van het discours mede is gebaseerd behoren tot de categorie 'geluid in Amsterdam' (72), 'geluid in steden' (45), 'geluid als natuurkundige fenomeen' (8) en 'geluid als bijproduct' (2).

\section{Casus 1940-1945}

Voor informatie over ervaringen en opvattingen over geluid tijdens de oorlog is bij gebrek aan ander materiaal enkel gebruik gemaakt van dagboeken. In kranten werd in die tijd geen of zeer weinig aandacht aan geluid besteed en als journalisten er al over schreven ging het over het geluid van de oorlog elders, ver buiten Nederland, of het geluid van zaken die zo neutraal of 'onschuldig' waren dat ze pasten in de mediapolitiek van de bezetters. ${ }^{36}$ Dagbladen en overige media waren immers bij de capitulatie meteen onder censuur geplaatst (Meershoek, 2007, p. 241). Dit gebrek aan informatie

\footnotetext{
${ }^{34}$ De oplage van De Telegraaf steeg van 28.529 in 1918 naar 115.657 in 1939; Leeuwarder Courant had een oplage van 10.500 in 1915 (Plasse \& Verbei, 2005, p. 192). Ontwikkelingen met betrekking tot de inhoud en vorm van dagbladen gedurende het interbellum komen in het betreffende hoofdstuk aan de orde.

${ }^{35}$ Wel zijn 95 artikelen uit Het Vaderland die betrekking hebben op de categorie 'geluid in steden' gebruikt om na te gaan of de inhoud en frequentie van de berichtgeving over geluid in het Algemeen Handelsblad vergelijkbaar is met een ander dagblad uit de betreffende periode.

${ }^{36}$ De 'Persdocumentatie Collectie Stadsarchief Amsterdam' (toegangsnummer 30486) bevat geen enkel krantenartikel uit de periode 1940-1945 over (oorlogs)geluid. Ook bevat geen enkel artikel uit 'Het Illegale Parool, archief 1940-1945' (http://www.hetillegaleparool.nl/) een kop waarin het woord 'geluid', 'lawaai' of 'stilte' voorkomt. Wel 1 keer 'herrie' maar dan gaat het om een ruzie binnen de N.S.B. Verder gaat het in een random selectie van 50 pagina's (uit een totaal van 827 p.) van het dagblad Het Vaderland uit de periode 10 mei 1940 - 1 juni 1945 waarop het woord 'geluid' voorkomt, 5 maal over de oorlog elders (Albanië, 'Oosten'), 5 maal over vogelgeluiden (artikelen over vogels), 8 maal over muziek/concerten, 12 maal over literatuur, filosofie of wetenschap, 2 maal over een inbraak en betreft het 19 maal een feuilleton. Er is slechts 1 artikel uit 1944 (augustus) dat handelt over het geluid van oorlogsgeweld in Nederland veroorzaakt door de geallieerden. Onder de kop 'Blijf thuis, reist niet, ook u loopt gevaar: Inzittende van beschoten trein vertelt ervaringen' wordt daarin verslag gedaan van de beschieting van een trein.
} 
over oorlogsincidenten in eigen land, wordt regelmatig genoemd door dagboekschrijvers en ze refereren ook naar de geruchtenmachine die daardoor op gang komt. ${ }^{37}$

Ook in het Stadsblad uit de periode 1940-1944, het officiële orgaan van de gemeente, is helemaal niets te vinden over (regelgeving over) geluid, hoewel de Kroniek van Amsterdam over de jaren 1940-1945 (Boer \& Duparc, 1948) wel een enkele maal verwijst naar geboden/verboden en berichtgeving over draaiorgels, klokken, carillons en sirenes. Voor teksten over het geluid van Amsterdam tijdens de oorlog, zijn we dus aangewezen op dagboeken die in die periode ter plekke geschreven zijn.

Dit onderzoek is gebaseerd op een verzameling van 30 dagboeken of egodocumenten in het bezit van het Nederlands Instituut voor Oorlogsdocumentatie (NIOD). Ook bij het NIOD worden historische documenten gedigitaliseerd en dit betekende dat gedurende mijn onderzoek slechts $1 / 3$ van de ruim 1500 dagboeken en egodocumenten kon worden geraadpleegd. In deze willekeurige selectie van 500 exemplaren - de documenten werden gedigitaliseerd in de volgorde waarin ze in bezit waren gekomen van het NIOD - bleken 139 exemplaren betrekking te hebben op Amsterdam. Dit kan betekenen dat Amsterdam als plaats aan de orde komt, maar er zijn ook dagboeken achteraf in Amsterdam geschreven die niet over Amsterdam gaan. Afgaande op de beschrijvingen in de catalogus van het NIOD, heb ik uit deze verzameling van 'Amsterdamse dagboeken' 30 exemplaren geselecteerd die gedurende de oorlog geheel of gedeeltelijk in Amsterdam zijn geschreven en waarin waarschijnlijk (ook) persoonlijke ervaringen en het dagelijks leven in de stad aan de orde komen. Er zijn namelijk nogal wat dagboeken die bijna uitsluitend het oorlogsverloop aan de fronten bijhouden. Omdat het bijhouden van een dagboek niet binnen alle geledingen van de maatschappij even vanzelfsprekend is, vormt deze groep van 30 dagboekschrijvers geen dwarsdoorsnede van de Amsterdamse bevolking. Toch zijn er meerdere maatschappelijke niveaus en leeftijdscategorieën vertegenwoordigd, bovendien wonen de auteurs redelijk verspreid over de stad. ${ }^{38}$ Tenslotte zien bijna alle dagboekschrijvers, net als de overgrote meerderheid van de Amsterdamse bevolking, de bezetter liefst zo snel mogelijk verdwijnen.

\section{Slot: Bronnen, genres en discours}

Omdat geluid nu eenmaal een ondergeschoven kindje is in teksten over het dagelijks leven in de stad, is in dit onderzoek noodgedwongen gebruik gemaakt van reisverslagen, memoires, dagboeken, brieven aan kranten, columns en artikelen uit kranten en een enkel weekblad. In principe kan hier van een scala aan genres worden gesproken, maar tegelijkertijd is er sprake van veel overlap en blijkt elk genre afzonderlijk moeilijk

\footnotetext{
${ }^{37}$ In een enkel geval voelt de schrijver van een dagboek zich geroepen om juist die geruchtenstroom en berichten uit het inofficiële circuit vast te leggen in zijn dagboek ( $d b$ : Verwey).

${ }^{38}$ Detailgegevens over de selectie zijn opgenomen in het betreffende hoofdstuk.
} 
af te bakenen. In publicaties over een specifiek genre is een deel van de introductie dan ook geregeld gewijd aan de vele vormen die het genre kan aannemen en aan de overeenkomsten met andere soorten tekst (Hooper \& Youngs, 2004, p. 3; Langford \& West, 1999, pp. 8-9). Elke auteur past de mogelijkheden van het door hem gekozen genre op een unieke wijze toe, maar is tegelijkertijd ook gebonden aan en beïnvloed door gangbare praktijken, opvattingen en de conventies van taal en literatuur in het algemeen. Dit kan zich bijvoorbeeld uiten in het al dan niet noemen van geluid, in de keuze van de geluiden waarover geschreven wordt, de woorden die daarbij gebruikt worden, de wijze waarop daarbij de eigen ervaring aan de orde komt en het oordeel van de auteur over dat geluid. Met andere woorden, elke auteur wordt beïnvloed door het discours van zijn tijd. Het gebruik van de verschillende soorten bronnen en genres is dan ook eerder een voordeel dan een nadeel in dit onderzoek naar het dominante discours over geluid.

In de volgende drie hoofdstukken gaan we met behulp van het analyseraamwerk en het bronnenmateriaal, dat waar nodig nog verder zal worden toegelicht, luisteren naar het geluid van Amsterdam in verschillende historische periodes en naar de betekenis voor en meningen over dat geluid van stadsgenoten. De aard van het beschikbare materiaal brengt met zich mee dat we, naarmate de tijd voortschrijdt, de stem van een steeds groter gedeelte van de bevolking te horen krijgen. Zoals zal blijken, is dat echter niet de enige reden waarom in de loop van de tijd niet alleen het geluid van Amsterdam maar ook het 'discours' over dat geluid heel anders gaat klinken. 



\section{"In een stad als Amsterdam wordt het eigenlijk nooit geheel en al stil": Stadsgeluid aan het einde van de negentiende eeuw}

\section{Inleiding}

In een stad als Amsterdam wordt het eigenlijk nooit geheel en al stil. Al woont men ook op een zoogenaamd stille gracht, toch hoort men altijd van uit de verte een geluid, dat aan 't verwijderd ruischen van de zee herinnert, nu eens zwakker, dan weer sterker, evenals de branding, die achter de duinen tegen 't strand slaat, zacht ruischend afvloeit en telkens met kracht terugkeert (Maurik, ca 1890, p. 217).

Omstreeks 1890 beschrijft schrijver en sigarenmaker Justus van Maurik de geluiden die hij hoort tijdens een nacht met vorst en een laag sneeuw op straten en daken. Nadat de "klok van den oude kerktoren" twaalf keer heeft geslagen, hoort hij vanuit zijn warme bed de verre geluiden van andere klokken, van een rijtuig, van gezang. Dan ratelen de wielen van een rijtuig over de brug en houden stil bij de buren. Gedempte stemmen, een schel, het openen en dichtslaan van een portier zijn te horen, waarna het rijtuig vertrekt en het geratel van de wielen langzaam wegsterft. Van Maurik slaapt in, maar voordat de klok zes uur slaat is hij al weer wakker. Achter zijn woning "in 't nauwe straatje, was reeds een porder aan 't porren geweest en hij maakt leven voor twee. Dáár wonen ambachtslieden, menschen die vroeg uit de veeren moeten." Rond die tijd komen ook van alle kanten de boeren naar Amsterdam. Eerst de groenteboeren en even later "al weer andere karren; ze ratelen onophoudelijk over bruggen en door de straten, allemaal melkkarren die in de stad komen." Tegen de tijd dat de oude klok negen uur slaat is in bijna alle "stadsgedeelten de bedrijvigheid ontwaakt" en heeft van Maurik naast het geratel van de karren, de kreten van venters gehoord en ziet hij overal "menschen draven, stappen of kuieren, al naar hun vak of tijd 't meebrengt" (p. 1-9).

Het geluid van stemmen, klokken, carillons, paardenhoeven, rijtuigen, wagens en handkarren die over de keien ratelen, zijn de constanten in van Mauriks beschrijving van Amsterdam tijdens het laatste kwart van de negentiende eeuw. Datzelfde gaat op voor de reisverhalen van de Italiaan Edmondo De Amicis, de Portugees Ramalho Ortigão, de Brit Charles W. Wood, de Fransman Henry Havard en de Belg Charles de Coster die Amsterdam in deze periode aandeden. Moeten we daaruit concluderen dat 
dit destijds de belangrijkste geluiden waren? Of zijn er andere redenen waarom, met uitzondering van één passage waarin Ortigão "het al onze zenuwen irriterende, alle poriën van onze huid prikkelende, oorverscheurende knarsen van" het kloven van diamanten beschrijft, ${ }^{39}$ het geluid van stoommachines, smederijen, blik- en koperslagers en andere nijverheid geen plek hebben in de stadsbeschrijvingen? Om deze vragen te beantwoorden wordt in dit hoofdstuk eerst aandacht besteed aan de vraag welke geluiden er op grond van de activiteiten en vormen van bewoning van de stad te horen moeten zijn geweest in de periode 1875 - 1895. Vervolgens komt de betekenis van deze geluiden aan de orde en de mate waarin en manier waarop men zijn mening over deze stadsgeluiden onder woorden bracht.

\section{"In de straat stijgt ratelend en schaterend het leven eener groote stad naar boven" 40}

In de eerste helft van de negentiende eeuw blijft Amsterdam qua groei ver achter bij andere Europese hoofdsteden. Die groei trekt enigszins bij in de tweede helft van de eeuw, maar blijft in vergelijking tot de rest van Europa toch verre van spectaculair. ${ }^{41}$ Desondanks verandert er voor de bewoners van Amsterdam veel, hoewel dat niet per se voorspoed betekent. "De geringe resultaten (van scheepvaart, goederen- en fondsenhandel) waren niet bij machte de ontwikkeling onzer stad te stuiten. (...) Verkeer en bedrijvigheid namen toe en voor het kalme Amsterdam van vroeger is vrij snel een woelige wereldstad in de plaats getreden" (Verslag Kamer van Koophandel 1882, p. 8 geciteerd door Ad Knotter in (Knotter, 1991, p. 49)). Volgens Knotter wordt Amsterdam niet alleen woelig door de groei van het aantal recent geïmmigreerde inwoners, maar ook door de toename van verhuisbewegingen in en uit de stad. $^{42}$ Daarnaast toont hij aan dat er tot 1900 groei zit in de financiële sector, de diamantbewerking, bouw, havenarbeid en in beperktere mate in de drukkerijen, terwijl er in de ambachte-

\footnotetext{
${ }^{39}$ (Ortigão \& Jong, 1885/1948, p. 150). Ook Salomon Rodrigues de Miranda, die in 1886 op 11 jarige leeftijd als leerling diamantslijper in de fabriek 'Bottenheim' aan de Nieuwe Achtergracht aan het werk ging, zegt in zijn boek Amsterdam en zijne bevolking in de negentiende eeuw niets over lawaai in de werkplaats.

${ }^{40}$ Algemeen Handelsblad, 30-08-1889, Ochtend.

${ }^{41}$ In de eerst helft van de negentiende eeuw groeide de bevolking van Amsterdam met 2\%, van Boedapest met $189 \%$, Brussel 280\%, Londen 140\%, Parijs 93\% en Rome 7\%. Van 1850 tot 1900 liet Amsterdam een groeipercentage zien van $128 \%$, Boedapest $370 \%$, Brussel $139 \%$ Londen $68 \%$, Parijs $150 \%$ en Rome $166 \%$. In 1850 telde Amsterdam 224.000 inwoners en vijftig jaar later 510.850. (Hall, 1986, p. 247 geciteerd in; Wagenaar, 1998, p. 23).

${ }^{42}$ Als gevolg van de agrarische depressie was er sinds 1878 een verhuisbeweging naar de steden. De 'ellende op het platteland maakte de steden voor veel mensen aantrekkelijker dan ze in werkelijkheid waren' (Kooij, 1985, p. 101). De trek naar Amsterdam van het platteland en uit andere steden ging ook na 1883 door maar een veel geringer aantal immigranten slaagde erin zich blijvend te vestigen. Er was onvoldoende werk voor de migranten die na 1883 kwamen en deze vertrokken op den duur dus ook weer (Knotter, 1991, pp. 49-51).
} 
lijk verzorgende en luxe nijverheid (de vervaardiging van kleding, schoenen, meubels, sigaren en goud- en zilverbewerking) sprake is van teruggang (p. 239).

De groei van de financiële sector en commerciële dienstverlening drukt zijn stempel vooral op het centrum van de stad en de grachtengordel. Geleidelijk verdrijven de expansie in de handels- en de bankwereld het wonen uit grote delen van de grachtengordel, omdat het oorspronkelijke kantoor aan huis te klein wordt. Ondanks de hoge grondprijzen vinden vervolgens ook nieuwe banken en verzekeringsmaatschappijen hun weg naar dit deel van de stad. De aanwezigheid op loopafstand van de Beurs, de Nederlandse Bank, het Post- en Telegraafkantoor spelen daarbij een rol. Niet alleen omdat het berichtenverkeer nog voornamelijk wordt onderhouden door loopjongens, bodes en telegrambezorgers, maar ook omdat handelspartners en hun experts elkaar regelmatig face-to-face ontmoeten.

In de jaren zeventig is de telefoon namelijk nog niet algemeen in gebruik. Op 10 december 1877 staat het volgende bericht in Het nieuws van den dag: kleine courant: "Hedenmiddag werd te Amsterdam door de firma Ferge en Lembeck aldaar eene proef met den telephon genomen. Het geluid van de menschelijke stem werd op eenigen afstand vrij voldoende door den toestel overgebracht. Evenwel schijnt ons de uitvinding nog te veel in haar eerste ontwikkelingsperiode te verkeeren om reeds nu ingrijpende hervormingen in het leven te kunnen roepen." ${ }^{43}$

Ontwikkelingen gaan echter snel. In september 1880 kent de gemeenteraad de concessie voor het aanleggen en exploiteren van telefoonverbindingen toe aan de International Bell-Telephon-Compagny op grond van de overweging "Dat in eene handelsstad als de onze groot nut van de medewerking van den telephoon is te verwachten." Daarbij gaat men er echter van uit dat de "Telephoon een communicatiemiddel tussen gemeentenaren" is, terwijl men de telegraaf als een landelijk medium ziet. Als in 1895 de concessie afloopt, is het idee dat de telefoon enkel op plaatselijk niveau betekenis heeft inmiddels ook passé (Zadoks, 1899, pp. 198, 201).

De bedrijvigheid die zich in en tussen kantoren afspeelt trekt toeleverende bedrijven zoals drukkerijen aan, maar ook de zich ontwikkelende landelijke pers en de horeca. Verder is het stadscentrum aantrekkelijk voor gespecialiseerde winkels en de opkomende warenhuizen, vanwege zijn goede bereikbaarheid en de (potentiële) klanten onder de in het centrum werkende bevolking (Wagenaar, 1990, pp. 145-148; 163-166).

De volgende beschrijving van een dag in de Kalverstraat toont de gevolgen van dit proces van cityvorming voor het dagelijks ritme in het hart van de stad en geeft een idee van het bijbehorende klanklandschap.

Het eerste tijdperk is tusschen 9 en 1 ure. Dan is de Kalverstraat zoo kalm en rustig als eenige wijk in de geheele stad. Eerst ontmoet ge de kinderen, die naar school

\footnotetext{
${ }^{43}$ 'Vervolg der Nieuwstijdingen', Het nieuws van den dag: kleine courant, 10-12-1877.
} 
gaan, (...) vrome Katholieken die zich naar de kerk, heeren die zich naar hun kantoor begeven: terwijl ge in de manufactuurwinkels dames en heeren bezig ziet, om de uitstalling in orde te brengen, of ge de spiegelglazen ziet schoonmaken. lets later vindt ge er jonge dames, die haar commissiën verrichten, vreemdelingen, die hun logementen hebben verlaten om 't merkwaardigste van de hoofdstad te zien, commis-voyageurs, die zich voortspoeden, orgeldraaiers, die tegen elkander indraaiende, $u$ de meest oorverscheurende muziek doen hooren, altijd nog een kalme drukte. Om twaalf uur tal van werklieden, die gaan schaften, joden met hun wagens met peren, appelen, citroenen of china'sappelen, vischboeren met hun kruiwagens, vischvrouwen met haar manden met levende bewoners der zee. Dan volgt er een oogenblik van stilstand.

Het tweede tijdperk is van 1 tot 6 uur. Eerst een stroom van heeren; deftige mannen en jonge lieden, die zich met versnelde stap naar de beurs begeven, welke om half twee begint. Dames van verdachte reputatie, aan wier houding en kleeding men 't kan merken, dat ze tot de "demi monde" behooren, (...) (Van 1 tot 3 ure vertoont zich geen fatsoenlijke dame zonder geleide van een heer in de Kalverstraat). $\mathrm{Nu}$ volgen de flaneurs, met of zonder dames: heeren, die op hun doode gemak de straat op en neer drentelen, voor verschillende winkels blijven staan en, wanneer ze alleen zijn, in't een of ander koffiehuis van hun vermoeienis gaan uitrusten, en door de ruiten kijken, om op hun beurt andere flaneurs, ook flaneuses op te nemen.

Daarna komt weer de stroom van beursbezoekers, meest twee of drie bij elkander, veelal druk pratende over de beursprijzen of den koers van de effecten. (...) Sommige hunner gaan 't een of ander koffiehuis binnen; anderen stevenen vooruit met dien echt Amsterdamschen stap, die u zegt: "time is money." Ge vindt er echter minder dan straks: velen, wier kantoren in de route liggen, hebben zich meestergemaakt van een plaats op de een of andere omnibus. ' $t$ Wordt nu hoe langer hoe drukker, vooral wanneer de wandelaars terugkeeren, om zich naar hun woningen te spoeden.

Tusschen 5 en 7 uur is de Kalverstraat genoegzaam ledig. Dan komen de bezoekers van schouwburg, varietés of volkspaleis, heeren en dames, op hun gemak loopende of haastig voortschrijdende, al naar zij besproken plaatsen hebben of niet. Ze worden opgevolgd door wandelaars, die een avondluchtje scheppen of eens gaan flaneeren; de koffiehuizen worden voller (Amsterdammer \& Gouw, 1875/1974, pp. 52-55).

In het jaar voorafgaand aan de publicatie van deze schets, is de Kalverstraat als eerste in de stad voorzien van asfalt. Bovendien is het de enige straat die slechts in één 
richting, van de Dam naar de Munt, bereden mag worden. Het asfalteren is een experiment van de dienst Publieke Werken en bedoeld om zowel de geluidshinder tegen te gaan van de met ijzer beslagen wielen op de straatkeien, als de 'flaneurs' te plezieren en zo de aantrekkingskracht van de winkels te vergroten (Buiter, 2005, p. 174). Toch blijkt het wegvallen van het geratel van de wielen op de keien, ook zijn nadelen te hebben. "De anders zoo waakzame politie heeft vergeten elke handkar, die de Kalverstraat door-wil, te noodzaken, om een schel aan te hangen. Nu loopt men daar gerust; eensklaps hoort men: hei! hei! ziet om, en bemerkt, dat men in gevaar is, van door een handkar te worden overreden" (Amsterdammer \& Gouw, 1875/1974, p. 31).

Niettegenstaande het 'stille' plaveisel in de Kalverstraat, zal in het stadscentrum het geluid van al deze passerende voetgangers, venters, orgeldraaiers, handkarren, wagens en rijtuigen met de groei van de financiële sector en commerciële dienstverlening enkel toenemen. "Op welk moment van de dag je er ook langskomt, de Kalverstraat is altijd vol leven. Tussen 3 en 5 uur in de ochtend is het er misschien even

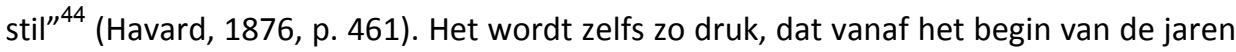
tachtig tijdens de flaneeruren, dat wil zeggen de middaguren en de vroege avond, geen handkarren meer door de Kalverstraat mogen rijden. Een verkeerstelling in de Hartenstraat in juni 1885 wijst uit dat er van maandag tot en met vrijdag tussen 7 uur 's ochtends en 10 uur's avonds gemiddeld per uur 1500 personen, 54 handkarren en 22 door paarden getrokken rijtuigen of wagens passeren. ${ }^{45,46}$ Het zou kunnen dat de Hartenstraat dan inmiddels geen keienbestrating meer heeft, maar zeker is dat niet gegeven het feit dat ook het Damrak en de Leidsestraat tot 1890 niet geasfalteerd zijn (Buiter, 2005, p. 175). Voor de generaties geboren en getogen in een wereld met asfalt en rubberen banden is het moeilijk een voorstelling te maken van het geluid van al deze activiteiten op straat. In 1938 beschrijft classicus en letterkundige Aegidius Willem Timmerman zijn herinneringen aan die geluiden als volgt:

Denken wij ons het auto-getoeter, het gemaal van muziekschijven, het jengelen van luidsprekers, indien mogelijk, een oogenblik weg, dan was het veel rumoeriger

\footnotetext{
44 "A quelque heure du jour qu'on s'y engage, on est certain de voir la Kalverstraat animée et vivante. A peine devient-elle silencieuse de trois à cinq heures du matin." Nederlandse vertaling: Marianne Bittremieux.

${ }^{45}$ Archief Secretarie Publieke Werken Amsterdam, inventarisnummer 144, zaaknummer 1861. De reden waarom deze verkeerstelling is gehouden heb ik niet kunnen achterhalen. Omdat de Hartenstraat in het verlengde ligt van de Damstraat en de Paleisstraat, lijkt het waarschijnlijk dat de telling te maken heeft met plannen om de oost-westroutes door de stad te verbeteren. Deze plannen zouden uiteindelijk leiden tot de doorbraak van de Raadhuisstraat in 1896 (Buiter, 2005, p. 169; Wagenaar, 1990, pp. 173-179).

${ }^{46}$ Ter vergelijking: een bewoner van de Kalverstraat zag in 1840 per uur minder dan de helft, namelijk in totaal 33 karren, wagens en rijtuigen passeren. Toen trokken op een dag door de straat: " 75 omnibussen met twee paarden, 47 batavieren, 5 calèches, 29 fourgons, 10 dokterskoetsen, 10 boerenwagens, 57 particuliere koetsen, 1 lijkkoets, 1 vrachtslede, 2 diligences, 1 koets, 57 vigilantes, 41 vrachtsledes, 17 molenaarskarren, 3 askarren, 3 vuilniskarren, 2 chaissen, 7 melkkarren, 14 brommers, 1 bakkerskar, 4 toesleden, 5 postkarren en 4 losse paarden" (Jager, 2002, p. 79).
} 
in de stad tóén dan nu. Géén asfalt, géén gummibanden, géén verbod van luidkeels venten, géén geheelonthouding, zelfs niet half, géén vaste dagen voor draaiorgels of andere muziekanten. Veerloze boerenkarren en vrachtwagens rateldonderden over de grove rondkoppige keien en deden de straten tweehonderd meter ver weerkletteren. Van 's morgens vroeg tot's avonds laat galmde het geroep van handelaars in lemoenen en sachlioenen, kanteloepen en appelsinen (...). 'sMaandags vooral zeilden troepen dronkelingen dwijlend de stad door, gearmd en schreeuwend $^{47}$ (...). Het krioelde er van de draaiorgels en straatmuziekanten (...). Ook hoorde je het geratel van de "vullisman", huzaren-geschetter, militaire muziekkorpsen, die bijna elken dag door de straten trokken, het zingen van heiers ${ }^{48}$ onder het vallen van het blok en het gerinkel der kettings (Timmerman, 1938, pp. 257-258).

Afhankelijk van de locatie kan het geluid van al deze activiteiten anders uitpakken. Het belang van de bestrating is al aan de orde gekomen. De Kalverstraat is vanwege het geluid geasfalteerd. Verder wordt er in deze periode ook geëxperimenteerd met houten plaveisel. In het gemeenteverslag van 1874 wordt aangedrongen op het aanbrengen van houten bestrating voor het gebouw van de armenschool in de Reguliersdwarsstraat "tot wegneming van het oorverdoovend geraas der rijtuigen. In dit lokaal moet men tegenwoordig (...) bij het openzetten der ramen tevens alle mondelinge onderricht in lezen, rekenen, geschiedenis, aardrijkskunde staken." ${ }^{49}$ Andere krantenberichten verhalen over proeven met hout, asfalt en granietbestrating in wereldsteden als Londen, maar ook in Haarlem. ${ }^{50}$ In het jaarverslag van de gemeente over 1887 lijkt asfalt een definitieve plaats te hebben veroverd. "De uitkomsten met de asphaltbestrating zijn over het algemeen zeer bevredigend. (...) het hinderlijk geruisch, dat voertuigen op eene keibestrating veroorzaken, wordt gemist" (Jager, 2002, pp. 321-322). Waarbij het 'missen' in dit geval een positieve betekenis heeft.

Behalve de bestrating is ook de breedte van de straat en de hoogte van de straatwanden van belang. Het laat zich raden dat de weerkaatsing van geluiden langs de

\footnotetext{
47 'Maandag houden'. Zie ook (Polak \& Vlugt, 1936, p. 37) en 'Saint Monday' in (E. P. Thompson, 1967).

48 "Te Amsterdam waren de voornaamste van deze arbeidsliederen die van de heiers. (...) Schrijver deze heeft het in zijn jeugd tallooze malen gezien en gehoord, doch was te jong om te begrijpen, dat men zulke dingen moet opteekenen, omdat zij bestemd zijn 'folklore" te worden. Hij heeft ook geen dezer liederen onthouden, behalve één regel: Hé, o hé, haal op die hé! Hij heeft velen tijdgenooten en ouderen gevraagd, of zij zich de woorden dezer heiersliederen herinnerden, doch het resultaat was negatief" (Polak \& Vlugt, 1936, p. 310).

${ }^{49} \mathrm{Bij}$ de daaropvolgende bespreking in de gemeenteraad van de gemeentebegroting over 1876, onderkent de voorzitter dat "dit geraas zeer onaangenaam kan zijn, maar dat het onderwijs er door belemmerd wordt, is niet bewezen. En begint men eenmaal voor ééne school met een ander plaveisel, dan zullen spoedig zoovele aanvragen volgen, dat het onmogelijk zal zijn daaraan te voldoen. Algemeen Handelsblad, 11-061875; 28-10-1875.

${ }^{50}$ Algemeen Handelsblad, 01-02-1875, 22-08-1880, 05-10-1880, 04-11-1880; Het nieuws van den dag: kleine courant, 31-05-1877, 01-12-2877, 08-05-1879.
} 
grachten met hun relatief brede profiel, heel wat milder is dan in de smalle straten. Bovendien zullen de bomen langs de grachten, gedurende de tijd dat ze bladeren dragen, ook zorgen voor enige verstrooiing van geluid.

De straat was zeer nauw, zooals ik reeds heb opgemerkt, met ongelijke steenen geplaveid, en had een sterken weêrklank. Een rijtuig dat er doorreed, ratelde met een geweld als een geheele geschutstrein (Wood \& Baarslag, 1878/2002, p. 55).

Tot het leven van Amsterdams elite hoorde de pracht van de equipages, van eigen rijtuigen en paarden. Mijn vader heeft mij eens alle rijtuigen, tien of meer, opgenoemd die in zijn vaders stallen stonden (Keizersgracht 452). (...) Twee zwarten en twee vossen. Welk een gezicht als zij aan de overkant van de gracht voorbij stoven, de slanke voorbeenen ver uitgrijpend, terwijl het lichte coupeetje driftig ratelend achter het span aanrolde. Soms viel hun draf in eenzelfden cadans, zoodat de ijzers een klinkend rhytme op de straatstenen uithamerden (Den Tex, 2009, pp. 179, 212).

Door de toenemende bedrijvigheid groeit ook de vraag naar openbaar vervoer. Naast de omnibussen, door paarden getrokken wagens, doet in 1876 de paardentram zijn intrede onder andere met lijnen via het Damrak en de Leidsestraat. ${ }^{51}$

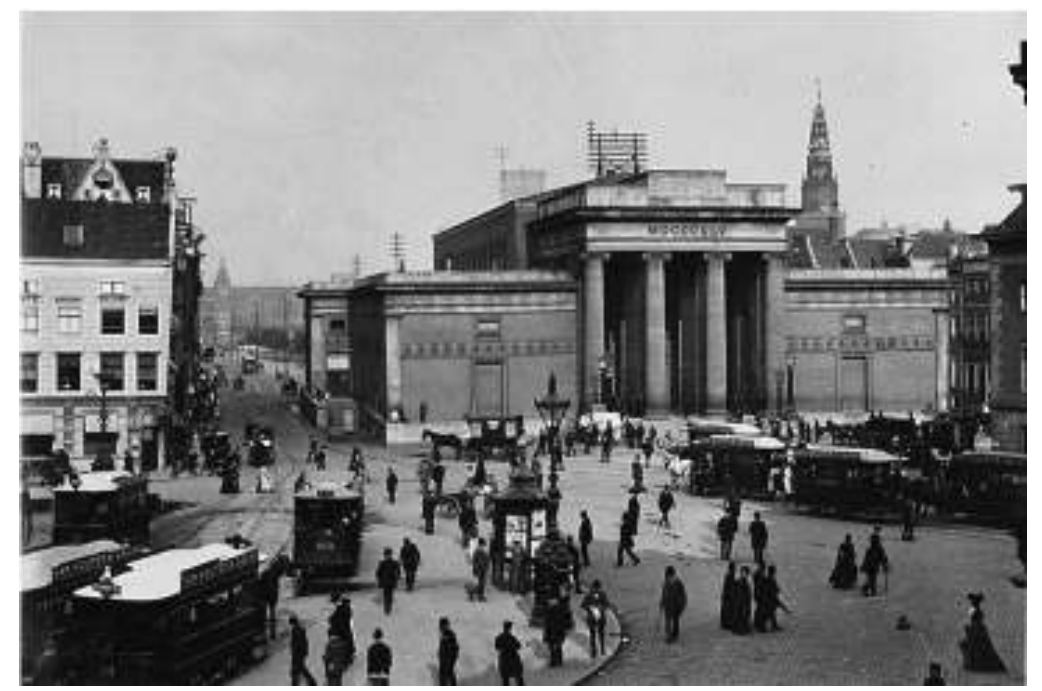

Afbeelding 2: Dam ca 1890, knooppunt van tramlijnen. Op de voorgrond zien we de beurs van Zocher (afgebroken in 1903) en in de verte het Centraal Station (Stadsarchief Amsterdam)

\footnotetext{
${ }^{51}$ De paardentram wordt in Amsterdam pas na 1900 vervangen door de elektrische tram, nadat er vanaf begin jaren negentig over allerlei alternatieven is nagedacht (Buiter, 2005, pp. 189-195).
} 
Bij het debat rondom de invoering van de paardentram spelen zowel lawaaioverlast als juist het ontbreken van 'geraas' een rol. Bewoners van de Reguliersbreestraat, de Leidsestraat en de Utrechtsestraat vrezen last te krijgen van het geluid van de tram (Buiter, 2005, p. 181). Bij de bespreking in de gemeenteraad daarentegen bestaat er blijkbaar geen twijfel over dat de tram minder lawaai maakt dan de omnibus en daarom zijn sommige sprekers van mening dat dit een nadeel oplevert: "hoe stiller een rijtuig over den weg gaat, hoe gevaarlijker, omdat men het niet kan horen aankomen" (Zadoks, 1899, p. 130).

De vrees voor ongelukken door te weinig geluid speelt overigens niet alleen bij de tram, maar ook bij sneeuwval.

Het is opmerkelijk welk een rol de schel in het Amsterdamsche straatleven begint te spelen. Vooral dezer dagen, nu er wat sneeuw op de straten ligt, tjingelt en klingelt het door de stad alsof zij één groot klokkenspel was. Zoodra er nl. sneeuw op de straten ligt - schrijft de stedelijke politie-verordening voor - moeten alle rijtuigen, wagens en karren voorzien zijn van een duidelijk klinkende schel. Geen rollend voorwerp op straat dat maar eenigszins met den naam van kar mag bestempeld worden of het geeft nu bij de minste beweging klank. Daarbij komt nog dat langs de geheele tramlijn Dam - Frederiksplein verklinkende en langgerekte klokslagen vernomen worden, dat eenige keeren per dag de nog luider klinkende klokken op de hollende brandweerwagens zich tusschen het algemeen gebengel hooren laten, dat de postkarren en postomnibussen elk hun eigenaardig belgeluid bezitten, dat vigelantes, equipages, sleeperskarren, ook de omnibussen der A.O.M. allen een eigenaardig metaal gerinkel veroorzaken - en men kan zich een flauw begrip vormen van het veelsoortig concert waarop dezer dagen de bewoners der hoofdstad onthaald worden (Het nieuws van den dag: kleine courant, 29-12-1877).

Binnen enkele jaren rijden de trams om de 5 minuten (Buiter, 2005, p. 189). Deze trams hebben bovendien nog geen vaste halte, maar stoppen op verzoek (Rooy, 2007b, p. 51). Vijf jaar later is de paardenspoorweg "gebleken een verkeersmiddel te zijn, aan een bestaande behoefte in die mate voldoende, dat het kan gezegd worden hier ter stede volkomen burgerrecht verkregen te hebben" (Zadoks, 1899, p. 133). Dit wil niet zeggen dat alle Amsterdammers van de paardentram gebruik maken. Voor arbeiders en armlastigen, tot in de jaren negentig ruim driekwart van de bevolking, is de tram nog steeds te duur en bovendien zijn de tijden waarop de tram rijdt op het werkritme van 'hoeden- en niet op dat van pettenmenschen' ${ }^{52}$ afgestemd (Buiter, 2005, p. 189; Rooy, 2006a, p. 382; Tijn, 1974a, p. 38). Deze mensen nemen dus de

\footnotetext{
52 "En in de stad-zelf dan! Een scherp onderscheid tusschen hoeden- en petten-menschen. Een werkman nog niet arbeider geheeten - droeg een pet, een heer droeg een hoed en bijna altijd een hooge, 's winters zwart, 's zomers van wit vilt" (Timmerman, 1938, p. 260).
} 
'benenwagen' en dat kan verklaren waarom er op een gemiddelde weekdag in juni 1885 meer dan 22.000 personen de Hartenstraat passeren. ${ }^{53}$

Fietsen is in het laatste decennium van de negentiende eeuw namelijk nog geen manier om je te verplaatsen maar een sport voor bemiddelden. "Elken Zondagmorgen reden honderden fietsers, de elite van de stad, uren lang in het Vondelpark rond, dronken een kopje koffie in het paviljoen of in het Melkhuis en reden daarna weder de lanen op en af tot het tijd werd voor de lunch" (Polak \& Vlugt, 1936, p. 193).

Wagens en rijtuigen samen met paardentrams om de 5 minuten zorgen niet alleen voor hoefgekletter, maar vragen ook om de beschikbaarheid van hoefsmeden. Vaak wordt het paard beslagen in een soort van huisje op straat. "Men vond dergelijke werkplaatsen niet slechts in zijstraten, doch op de drukste punten. Zoo heeft schrijver dezes er een gekend op de Botermarkt (Rembrandtplein) waar hij geboren is en zijn jeugd heeft doorgebracht" (Polak \& Vlugt, 1936, p. 281). Maar niet alleen de hoefsmeden werken op straat. Ook ambulante werkers als kuipers (herstellers van wastobben) en scharenslijpers werken op de stoepen voor de huizen. ${ }^{54}$ En dan zijn er natuurlijk de venters en straatmuzikanten.

Hoewel er in de loop van de negentiende eeuw politieverordeningen komen die er vooral de overlast van het venten voor het verkeer willen tegengaan ${ }^{55}$ is de straathandel in beginsel vrij en kan een venter zelf bepalen waar hij wil venten en met welke artikelen (Huberts, 1940, pp. 19-20). Venten is bovendien de enige optie die open blijft als alle andere mogelijkheden om aan werk te komen zijn uitgeput. Tijden van grote werkloosheid, zoals in de jaren tachtig, drijven dan ook vele mannen, vrouwen en kinderen als venter de straat op (Groot, 1988).

Er heerst in de Jodenbreestraat een herrie en lawaai waarvan men zich geen idee kan vormen als men het niet gehoord heeft. Al deze kleine kooplui roepen, gesticuleren, glimlachen om klanten te trekken, noemen prijzen, venten, verkondigen wat zij verkopen of kopen en prijzen hun kwaliteiten aan. En wat voor stemmen! Het

\footnotetext{
${ }^{53}$ Op foto's van Jacob Olie uit de periode 1860-1895 dragen de meeste mensen schoenen. Ook werklieden en zelfs de kinderen in de steeg 'Gebed zonder End' (tussen Nes en Oudezijds Voorburgwal). Klompen zijn te zien bij hoefsmeden en soms bij kinderen die op bouwplaatsen of vaarten aan de stadsrand spelen (Olie, 2007).

${ }^{54}$ Hoewel kuipers en scharensliepen niet meer in alle straten van het centrum te vinden zullen zijn geweest, laat de omvang van de bewoning gedurende het laatste kwart van de negentiende eeuw toch vermoeden dat ook hier nog geregeld van hun diensten gebruik werd gemaakt. De cityvorming zorgt voor een daling van het aantal woonhuizen in de stad, maar niet voor een teruglopende bevolking. "Tussen 1859 en 1909 nam het aantal woonhuizen in de oude stad tussen IJ, Singel, Amstel, Nieuwe Herengracht, J.D. Meyerplein, Elandsgracht en Oude Waal af van 7.298 tot 5.375. (...) Niet alleen arbeiders moesten verdwijnen, maar ook vele welgestelden trokken weg. De bevolking van de oude stad steeg van ongeveer 240.000 in 1860 tot bijna 330.000 in 1890 om daarna snel af te nemen" (Hoekveld, 1964, p. 133).

55 "Om de verkoopkansen zo groot mogelijk te maken, trekt hij langzaam door de dichtst bevolkte wijken, begeeft zich naar de drukke verkeerswegen, blijft graag op de hoeken van straten staan en houdt zich bij voorkeur op in de omgeving van markten en winkels, waar hij kopers weet" (Huberts, 1940, p. 21).
} 
zijn neus- en keelklanken in alle toonaarden. De kleinen roepen in majeur en de groten in mineur. Alle reclamefoefjes worden door deze bekwame handelaars gebruikt. Zij trekken de aandacht met ratels, castagnetten of slaan op oude pannen. En daar is nog een ratel, een heel grote: die van de stad. Een joodse jongen laat hem met grote ernst draaien. Hij weet er zelfs een militaire mars uit te halen. Op deze wijze wordt de aandacht van de huismoeders erop gevestigd, dat de gesloten wagen in aantocht is die bij elke huisdeur het huisvuil komt ophalen. Een gebochelde jood heeft zich voor een karretje met turf gespannen. Op de turf zit een kleine jongen die een trompet nadoet en uitnodigend wenkt tot de voorbijgangers. (...) een jongetje met kromme benen loopt ervoor en tracht zijn waar te slijten door met een doos vol spijkers te rammelen. Een orgel speelt Mere Angot en een ander draait het jammerend lied af van de Leeuw van Nederland dat enkele mannen en een vrouw in lompen meegalmen (Coster \& Janson, ca 1879/1998, pp. 36-37).

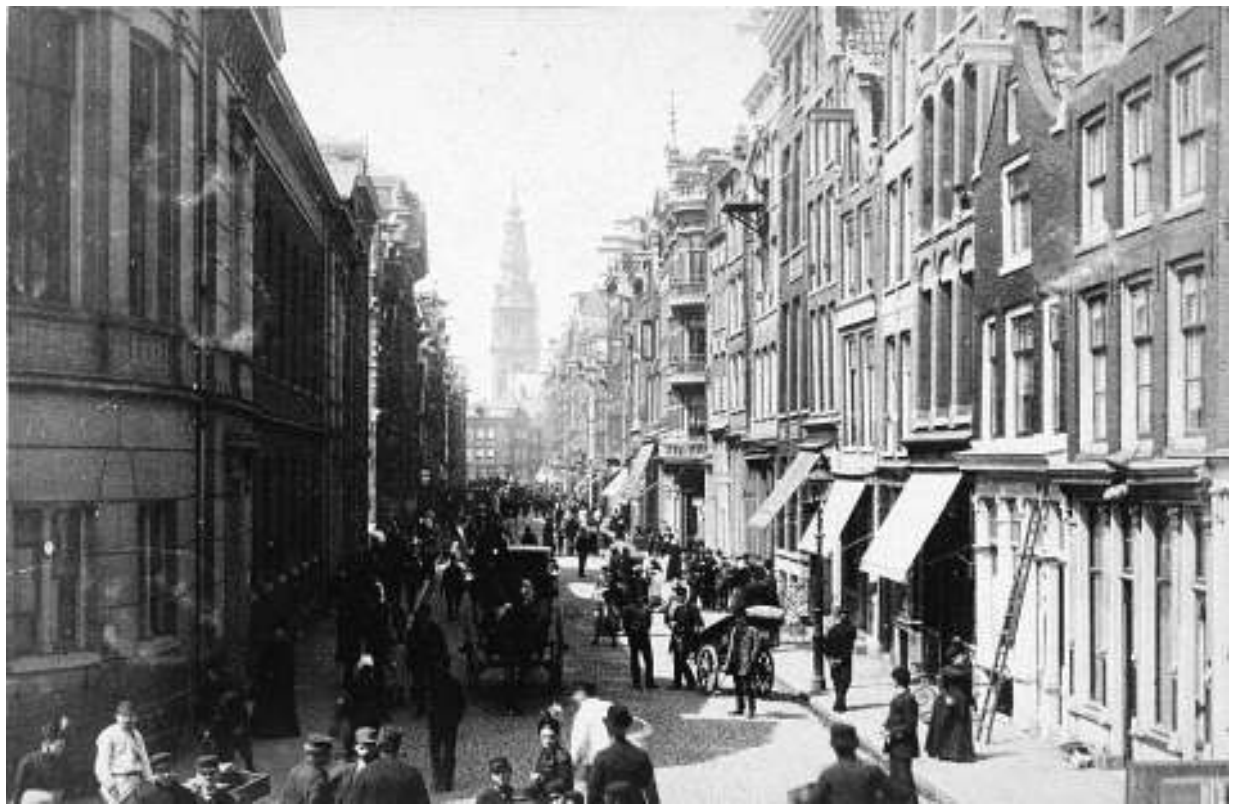

Afbeelding 3: Jodenbreestraat 1886, voetgangers, venters, handkarren en rijtuigen (Stadsarchief Amsterdam)

De paarden die rijtuigen, tram en karren door de straten trekken, zijn overigens niet de enige dieren die in de stad te vinden zijn. Herinneringen ophalend aan de jaren achttienzeventig zegt Kluytenaar: "Wij wenschen voor Amsterdam de tijden niet terug, dat er, zooals ik in mijn prille schooljaren vaak zag, kudden schapen en koeien langs de grachten en straten gedreven werden, en een viertal ezelinnen onder begeleiding, 
voor de huizen der zieken en zwakken stonden en gemolken werden; dat men het slachtvee in de kelders van slagers zag duwen en het slachten kon zien en hooren" (Kluytenaar, 1936, p. 255). Tot 1875 scharrelen er volgens vakbondsvoorman en politicus Henri Polak nog de hele dag kippen op het Rembrandtsplein, op grond waarvan hij constateert dat het daar toch niet zo druk kan zijn (Polak \& Vlugt, 1936, p. 138). Verder herinnert Salomon Rodrigues de Miranda, eveneens leider van de Algemeene Nederlandsche Diamant-bewerkersbond (ANDB) en later wethouder van Amsterdam, zich dat met de totstandkoming van de dienst Bouw- en Woningtoezicht in 1880 ook nieuwe regels verschijnen en dat "optochten van kippen op straten en plantsoenen niet meer worden toegelaten." Wel weet hij dat het houden van koeien in de stad zeker nog geruime tijd stand hield (Rodrigues de Miranda, 1921, pp. 139, 168). Zelfs in 1893 wordt nog een vergunning toegekend om een koe te mogen houden op de Kerkstraat 261, dus binnen de Singelgracht. ${ }^{56}$

Het geluid van alles wat zich verplaatst in de stad: voetgangers, venters, straatmuzikanten, handkarren, wagens en rijtuigen kenmerkt niet alleen het centrum van de stad, maar ook andere winkelstraten en de toegangswegen. Voor een aantal straten komt daar het geluid van de paardentram en de omnibus bij, maar er is natuurlijk ook geluid van bronnen die niet 'voorbij gaan'. Dat zijn de geluiden van huishoudelijke en/of beroepsmatige activiteiten op een vaste locatie.

\section{“Waarom geduld dat er des nachts op de werf wordt gewerkt?"57}

In negentiende eeuws Amsterdam zijn de verschillende welstandsgroepen op wijkniveau gemengd, al zijn er wel graduele verschillen tussen de wijken. In de Jordaan bijvoorbeeld woont de gegoede burgerij langs de grachten, ambachtslui in de zijstraten en ongeschoolde werklieden, zeelui en paupers in de sloppen en gangen (Wagenaar, 1984, p. 158).

Huishoudelijke werkzaamheden als het uitkloppen van kleden, het poetsen van laarzen en (koperen) keukengerei worden op straat uitgevoerd. "Op de grachten werden ook "kleeden" geklopt, kachels schoongemaakt, de wasch opgeheschen: de straat werd als een soort voorplein van het huis gebezigd" (Kluytenaar, 1936, p. 253). Verder worden regelmatig de ramen gewassen en de straat voor het huis geveegd. Buitenlandse bezoekers vinden al dat poetsen en schrobben op straat wel grappig. Volgens de Portugees Ortigão behoort de Nederlandse straat aan de dienstboden en wordt Amsterdam op zaterdag binnenste buiten gekeerd. "In woonhuizen, magazijnen, winkels, kantoren, overal wordt alles overhoop gehaald, afgestoft, uitgeklopt, schoongeborsteld, met een ijver, met een furie, een fanatisme, dat aan het delirium grenst" (Ortigão \& Jong, 1885/1948, p. 36). Esther Singleton uit de V.S beweert dat tapijten en

\footnotetext{
${ }^{56}$ Archief Secretarie Publieke Werken Amsterdam, inventarisnummer 3975, zaaknummer 4689.

${ }^{57}$ Algemeen Handelsblad, 12-01-1895.
} 
kleden elke dag uit huis worden gehaald en geklopt (Singleton, 1906, pp. 46-47). Slotstuk van al deze zindelijkheid is de rateljongen die tot in de jaren twintig van de twintigste eeuw de bewoners al ratelend waarschuwt dat de wagen die het huisvuil komt ophalen in aantocht is. Voor de Jordaan en andere arme buurten kondigt een ratel bovendien de 'poepkar' aan die de fecaliën komt ophalen (Rooy, 2006a, p. 373).

Naast de vermenging van welstandsgroepen op wijkniveau is er in het Amsterdam van de negentiende eeuw ook nog geen scheiding van wonen en werken, al is er wel van oudsher sprake van een selectie in de locatie van bedrijvigheid op basis van milieuhinder. "Het kantoor-aan-huis, of het pakhuis naast het woonhuis was in de Grachtengordel een vertrouwd beeld, maar milieuverontreinigende bedrijvigheid werd hier van meet af aan geweerd. In de Jordaan of op het Roeterseiland vond men de laatste categorie weer wel - in de zijstraten althans - waar de ambachtsman dikwijls naast of boven zijn werkplaats woonde" (Wagenaar, 1984, p. 158).

Eerder zagen we al dat in het laatste kwart van de negentiende eeuw de woonhuizen met kantoren aan de grachtengordel geleidelijk plaats maken voor kantoorpanden. Het enige door stoomkracht aangedreven bedrijf dat zich in 1876 in de buurt 'Grachten-Zuid $1^{158}$ bevindt is er dan ook in 1900 niet meer. De 171 bedrijven in de oude stad die in 1876 over één of meer stoommachines beschikken, zijn vooral te vinden in de Jordaan, Kadijken en de Oostelijke en Westelijke Eilanden. Tot 1900 groeit het aantal bedrijven met stoomkracht in deze wijken fors, zij het minder dan in de Jodenbuurt en de nieuwe wijken buiten de oude stadsrand.

Ook tijdgenoten maken zich zorgen. De stank, het lawaai, het brand- en explosiegevaar en de uitstoot van roet en gassen veroorzaken overlast in een wijde omgeving, niet zelden gedurende 15 tot 16 uur per dag. Bovendien hebben niet alleen pauperwijken als de Jordaan of de Kadijken, maar ook (lagere) middenklassewijken te kampen met de gevolgen van de industrialisering. Een klacht over een stoommachine in de buurt van Warmoesstraat 171 vermeldt een "aanhoudend, geweldig geraas, dat dikwerf zelfs des zondags van 's morgens vroeg tot aan den avond onophoudelijk voortduurt" (Wagenaar, 1990, p. 217). Een andere klachtenbrief uit dezelfde straat over een stoommachine gaat vergezeld van een door 8 personen getekende verklaring "dat het verblijf in de kamers van het belendende huis $\mathbf{J} .57$ onder de voortdurende trilling en het aanhoudende stampen door bedoeld stoomwerktuig veroorzaakt, hoogst onaangenaam en op den duur onhoudbaar is. ${ }^{\prime 59}$ Zelfs de inwerkingtreding van de Fabriekswet op 2 juni 1875 (de latere Hinderwet) brengt tot 1900 niet veel soelaas, omdat zoals ook uit onderstaande klacht blijkt, vergunningen zelden geweigerd worden (Wagenaar, 1990, pp. 212-217).

\footnotetext{
${ }^{58}$ Dit omvat de 'Gouden Bocht' en de omgeving van het Frederiksplein (Wagenaar, 1990, p. 150).

${ }^{59}$ Archief Secretarie Publieke Werken Amsterdam, inventarisnummer 1472, zaaknummer 25.
} 
Mag ik u eenige plaatsruimte verzoeken voor het in het openbaar uiten van een klacht en een verzoek, nu adressen aan B. en W., en persoonlijke bezoeken tot het uitbrengen dezer klacht bij verschillende stedelijke regeeringspersonen onvruchtbaar zijn gebleken! (...) Achter mij bevindt zich een werf, waarop van 's morgens zes tot 's avonds negen uur, (somtijds ook's nachts door!) het geluid van den klinkhamer vernomen wordt, of erger nog zoo mogelijk, waarop op zeer primitieve wijze een plaat, door het slaan met groote hamers, in de vereischte bocht wordt gebracht. (...) En nu kan men van de brug bij de Weteringschans zich overtuigen (voor de omwonenden is dit natuurlijk geheel niet nodig!) dat de man ook daarin ijzeren schuiten bouwt, zoodat het geklop en gehamer een 20-tal meters dichter bij onze woningen is gebracht! (...) Nu vraag ik $u$, M. de Red., is er nu toch niet in alle reden voor $B$. en $W$. handelend op te treden, en gebruik te maken van het recht tot sluiting der werf, althans van dat nieuwe gedeelte volgens art. 21 der zoogenaamde fabriekswet. Waarom geduld dat er des nachts op de werf wordt (geklonken en geklopt) gewerkt? Als dat niet burengerucht is, wat is het dan? (Algemeen Handelsblad, 12-01-1895).

Het 'geraas' van de stoommachine is nog maar enkel het geluid van de aandrijving. Daarbij komt natuurlijk ook nog het geluid van werkzaamheden die ermee worden verricht, uiteraard in zoverre die geluiden niet overstemd worden door de stoommachine. We weten niet met zekerheid welke werkzaamheden dat zijn, maar het lijkt aannemelijk om deze te zoeken in notoire lawaaiproducenten als de diamantindustrie, drukkerijen, scheepsbouw en smederijen. ${ }^{60}$ "Het al onze zenuwen irriterende, alle poriën van onze huid prikkelende, oorverscheurende knarsen van" het kloven van diamanten is in het begin van dit hoofdstuk al genoemd. Van 1875 tot 1889 neemt het aantal diamantslijperijen toe van 15 naar 70 en het aantal molens ${ }^{61}$ van grofweg 1350 tot 7500. Parallel hieraan groeit in de periode 1875 - 1895 het aantal toegekende Hinderwetvergunningen van 60 naar $536 .^{62}$

\footnotetext{
${ }^{60}$ Omdat een stoommachine voor het midden- en kleinbedrijf een te grote investering is, moet de toepassing van deze krachtbronnen vooral worden gezocht in de grotere bedrijven en tevens in de branches die het goed doen aan het eind van de negentiende eeuw. Voor Amsterdam zijn dat de diamantbewerking, bouwvakarbeid, havenarbeid en in beperktere mate in de drukkerijen (Wagenaar, 1990, p. 210). In die fabrieken en werkplaatsen zelf lijkt lawaai of beter 'gedruisch' geen onderwerp waaraan veel aandacht wordt besteed. In de Amsterdamse verhoren van het rapport De arbeidsenquête van 1887 wordt het woord 'gedruisch' twee keer genoemd en 'geraas' en 'geratel' geen enkele keer (Anoniem, 1887/1981/2008).

${ }^{61}$ In de diamantbewerking is een 'molen' of 'slijpmolen' een ronddraaiende schijf waarop de te bewerken steen wordt vastgezet om deze tot een diamant te kunnen slijpen (Leviticus \& Polak, 1908).

${ }^{62}$ Ook voor de inwerkingtreding van de Fabriekwet of Hinderwet op 2 juni 1875 werden er (in Amsterdam) al vergunningen afgegeven voor het voeren van een bedrijf op een bepaalde plaats. De oudste van de minimaal 60 vergunningen voor diamantslijperijen die voor 1875 zijn afgegeven dateert uit 1666 . Verder is het van belang te weten dat meerdere vergunningen betrekking kunnen hebben op een en dezelfde locatie. Niet alleen omdat in de loop van de tijd vergunningen elkaar opvolgen, maar ook omdat soms aparte vergunningen vereist zijn voor de diverse onderdelen van een bedrijf. De groei van het aantal vergunningen na juni
} 
Vanwege het feit dat tot 1900 de keuze voor de locatie van een bedrijf nog in hoge mate wordt bepaald door de nabijheid van de beroepsbevolking, mogen we aannemen dat het gros van de nieuwe Joodse slijperijen in en rondom de Jodenbuurt terecht komt en de nieuwe Christenfabrieken in de Jordaan en omgeving. Bijgevolg klinkt in de Jodenbuurt en omgeving van zondag tot en met vrijdag minimaal 12 uur per dag het 'geraas' van stoommachines en het 'geknars' van diamanten, terwijl hetzelfde lawaai in de Jordaan van maandag tot en met zaterdag te horen is (Tijn, 1974b, pp. 50-53, 68; Wagenaar, 1990, p. 211).

Over de uitbreiding van andere 'geraas en gedruisch' veroorzakende bedrijvigheid in de stad zijn ook geen precieze cijfers te geven. Duidelijk is wel dat voor een aantal branches het aantal toegekende Hinderwetvergunningen in de periode 1875 - 1895 explosief stijgt. Voor drukkerijen is er een groei van 32 naar 95 vergunningen, voor smederijen van 222 naar 640 en voor blikslagerijen zelfs van 6 naar 305. Rekening houdend met de eerder gemaakte opmerking dat meerdere vergunningen betrekking kunnen hebben op eenzelfde locatie, maar dat er ook vergunningen verloren zijn gegaan, kunnen we in ieder geval constateren dat in deze periode de lawaaiproducerende bedrijvigheid in de stad substantieel toeneemt. ${ }^{63}$

Zoals we eerder zagen, doen de kwalijke gevolgen van de industrialisering zich eigenlijk in de hele stad gelden, maar toch krijgen de delen van de stad waar het toch al niet zo fris is, en de grondprijzen dus het laagst zijn, het meeste te verduren. De lage grondprijzen trekken niet alleen kleine, ambachtelijke en lawaaierige bedrijven aan, zoals smederijen, die met een moordende concurrentie te maken hebben, maar ook de armlastigen die op zoek zijn naar een betaalbare woonruimte (Rooy, 2006b, p. 456; Wagenaar, 1984, p. 160; Woud, 2010, p. 49). In 1873 verschijnt een rapport over de Amsterdamse kelderwoningen waarin op dat moment 20.644 mensen huizen, gemiddeld 4,14 bewoners per kelder. Bijna de helft van de kelderwoningen is behalve als woning ook als bedrijfsruimte in gebruik. De woonomstandigheden op zolders zijn niet veel beter. De gevolgen voor de overlast in deze woningen, ook in de vorm van geluid, laten zich raden. Toch leidt het rapport niet tot ingrijpen door de overheid. Er gaat eerder een verlammende werking van uit, waardoor huizenspeculanten vrij spel

\footnotetext{
1875 zal om die reden gedeeltelijk samenhangen met een uitbreiding van de aan de wetgeving verbonden administratieve procedures. Anderzijds is uit een inventarisatie uit 2000 gebleken dat in de jaren zeventig/tachtig van de twintigste eeuw veel dossiers van de gemeente Amsterdam verloren zijn gegaan. In de genoemde inventarisatie (gericht op het in beeld brengen van locaties met bodemverontreiniging) zijn voornamelijk locatiedossiers aangelegd van bedrijven die in de jaren zeventig/tachtig nog in bedrijf waren. In deze dossiers zijn ook de oude (Hinderwet)vergunningen opgenomen. Het aantal Hinderwetvergunningen dat, bijvoorbeeld voor de periode 1875 - 1895, te vinden is in de locatiedossiers is dus een deelverzameling van het aantal vergunningen dat destijds is toegekend. Met dank aan Sible Harmsma, Senior Adviseur Milieu\&Leefomgeving, ARCADIS Nederland BV.

${ }^{63}$ Bron: Inventarisatie van de Hinderwetvergunningen Amsterdam uitgevoerd in 2000.
} 
hebben en overal in de stad (ook op de beter locaties) in korte tijd, zonder enige vorm van toezicht, duizenden huizen worden gebouwd ${ }^{64}$ (Ottens, 1975, pp. 8-11).

Onze huizen in de oude stad staan voor't grootste gedeelte op hun eigen vier muren, met een snijding tusschen de belendende; deze gebouwen hebben gemeenschappelijke muren, zoodat ge, als uw buurman ruzie met zijn vrouw heeft, dat duidelijk kunt hooren, en ge ongelukkig zijt te land gekomen, als zijn dochter pas aan de piano begonnen is (Amsterdammer \& Gouw, 1875/1974, p. 98).

Niet eerder dan in 1902 komt, met de inwerkingtreding van de Woningwet, voor de meerderheid van de Amsterdamse bevolking een structurele verbetering van de woonomstandigheden op gang. Maatregelen om elite wijken te vrijwaren van hinder, zijn dan in de Vondelparkbuurt al vier decennia met succes toegepast. Zo staat bijvoorbeeld in de koopakte (waarschijnlijk uit de jaren tachtig) van twee percelen in de Anna Vondelstraat de bepaling: "dat geen fabriek of trafiek en geen nacht-dans-koffiewijn-bier of speelhuizen, noch inrichtingen van publieke vermakelijkheden mogen worden opgericht of gesticht, terwijl ook in de te bouwen percelen generlei winkelzaak van welken aard zal mogen worden uitgeoefend" (Bruin \& Schijf, 1984, p. 143). De Vondelparkbuurt is daarmee de eerste stadswijk in Amsterdam waarin er geen sprake meer is van vermenging van verschillende welstandsgroepen (Heinemeijer, 1987, p. 145).

Andere voorbeelden van maatregelen om de betere wijken en de elite te vrijwaren van lawaai zijn terug te vinden in de diverse plannen voor de inrichting van het Museumterrein (huidige Museumplein). In het plan Jitta wordt de doorrit van het Rijksmuseum niet gebruikt omdat de ontwerper vreest "dat het rijtuigverkeer (...) door het geraas de aandacht der bezoekers afleiden." Het plan van Cuypers waarin het terrein bedoeld is voor "volksfeesten, wapenschouwingen, tentoonstellingen, oefenspelen, wedstrijden en dergelijke" stelt dat "Mocht zoveel bedrijvigheid op den duur hinderlijk blijken te zijn voor de omwonenden, dan zou om het geheele veld een dichte zoom van heesters en bloemhout aangeplant kunnen worden, waardoor het geluid aanmerkelijk wordt gedempt." ${ }^{\prime 65}$

Mag er dus vooralsnog in de stad als geheel geen sprake zijn van homogene wijken en een scheiding van wonen en werken, qua geluid is er een wereld van verschil

\footnotetext{
64 "In minder dan 30 jaar ontstond zo de Pijp, die van een woonwijk met nog geen 1500 inwoners in 1869 uitgroeide tot een dichtbevolkt stadsdeel dat in 1900 al bijna 50.000 inwoners telde" (Heinemeijer, 1987, p. 141). De povere kwaliteit van de woningen die door de speculanten, ook wel 'revolutiebouwers' genoemd, werden neergezet blijkt uit de volgende observatie uit Den Haag. "Die [woningen] zijn zoo dun en gehoorig, dat als 's morgens de melkboer in de buurt schelt, niemand weet aan welk huis de man zijne komst heeft aangemeld, omdat allen het even duidelijk hooren. Verschuift men een stoel, dan geeft dit in tien andere woningen dezelfde gewaarwording" (Gram, 1893, p. 27) geciteerd in (Woud, 2010, p. 50).

${ }^{65}$ Algemeen Handelsblad, 11-10-1891, 08-11-1891.
} 
tussen elite buurten aan de grachten, rond het Frederiksplein, het Vondelpark, Museumplein en de Plantage enerzijds en de rest van de stad. In de Kalverstraat "Wemelt het tot in de nacht van mannen en vrouwen, heren en dames, in allerlei stemming en allerlei soort; en in een pas of wat is men uit de verlichte straat op de donkere grachten, tussen de onbeweeglijk stilliggende schepen, bij een diepe stilte" (De Amicis, Lodeesen, \& Fagel, 1876/1985, pp. 196-197). Blijkbaar is er doorgaans langs de grachten zo weinig geluid dat het typische geluid van een bepaalde koets die naderbij komt niet gemaskeerd wordt en te herkennen is.

Ja zelfs het eigenaardig ratelen, dat elk koetsje eigen was, kende men van verre reeds, van dr. Zoutendam, Ter Maten, Fabius, Van Geuns, den tandarts Cerke met $z^{\prime} n$ coupétje met tweespan schimmels; - ik doe slechts'n greep uit vele. Dat alles gaf iets vertrouwds, iets gezelligs, iets van tot 'n gemeenschap te behooren. Men reed visites in coupétjes; naar station, "comedie" ging men per "vigilante" (Kluytenaar, 1936, p. 252).

In andere wijken, zoals onderstaande voorbeelden uit de Warmoesstraat illustreren, hoeft men ook op zondagen en 's nachts niet altijd op stilte te rekenen. Daar doen kort na het verstillen van het nachtelijk vertier, de porders ${ }^{66}$ hun werk en vlak daarna ratelen de karren de stad al weer binnen (zie begin van dit hoofdstuk).

Een aanhoudend, geweldig geraas, dat dikwerf zelfs des zondags van 's morgens vroeg tot aan den avond onophoudelijk voortduurt (Wagenaar, 1990, p. 217).

Maar om op het hotel terug te komen; want wij hebben nog niet met al het hinderlijk gedruisch afgedaan. Voor een slapeloozen logeergast was dat klokkenspel zeker in de hoogste mate ergerlijk. (...) maar nog erger dan de klok was 's avond en 's nachts het rumoer op straat. (...) Omstreeks elf uur (...) wilde ik in mijn bed eene welverdiende rust zoeken. Helaas! (...) Juist op dat uur begon de tijd dat luidruchtige dronken mannen en vrouwen, van de gemeenst mogelijke soort, uit de kroegen kwamen, en tot twee uur in den ochtend viel er aan slapen niet te denken (Wood \& Baarslag, 1878/2002, pp. 54-55).

\section{Zingen, luiden, trommelen en oproer kraaien}

Er zijn aan het eind van de negentiende eeuw ook activiteiten in de stad die niet gerelateerd zijn aan de standing van een buurt, zoals diverse grote bouwprojecten en het dempen van heel wat grachten om gezondheids- en/of verkeerstechnische rede-

\footnotetext{
${ }^{66}$ Porders zijn 'menselijke' wekkers die op afspraak personen wakker maken door op deuren te bonzen en te roepen.
} 
nen $^{67}$ (Rooijen, 1995). Tussen 1876 en 1888 wordt gebouwd aan het Rijksmuseum, Centraal Station, Concertgebouw, Panopticon (aan de Amstelstraat) en de Parkschouwburg in de Plantage. Het Centraal Station bijvoorbeeld, is gebouwd op 8687 houten palen (VVV, 2011). Op alle grote bouwlocaties samen moeten de heiliederen dus heel vaak te horen zijn. "De heiers [trokken] het blok omhoog, tien of twaalf man, elk aan een touw, alle touwen verbonden met dat waaraan het blok hing. Het optrekken en loslaten moest natuurlijk precies gelijktijdig geschieden en daartoe zong de voorman-heier of ploegbaas liederen, op welker rhythme getrokken en losgelaten werd" (Polak \& Vlugt, 1936, p. 310). ${ }^{68}$ Verder is het gissen of deze bouwprojecten en het dempen van de grachten voor veel geluid zorgen. De demping van grachten vindt door de hele stad plaats, maar de bouwputten zijn voornamelijk aan de negentiendeeeuwse stadsrand te vinden. Bovendien is op de locaties waar de aanvoer van bouwmateriaal per schuit of schip mogelijk is, vanzelfsprekend minder of geen lawaai van wagenwielen. $^{69}$

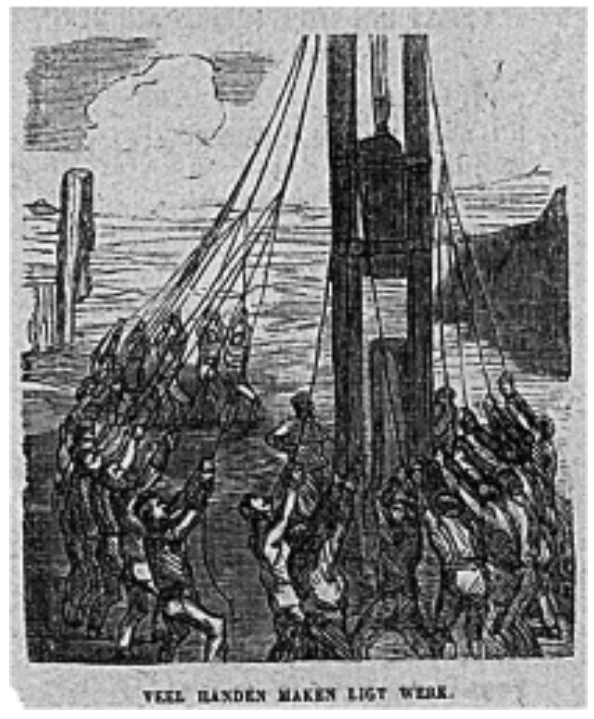
Afbeelding 4: "Veel handen maken ligt werk", ongedateerde houtsnede die laat zien hoe een heiblok door een grote groep heiers omhoog wordt gehesen (Stadsarchief Amsterdam)

\footnotetext{
67 “Nadat er in de hele stad ten tijde van de eerste twee 'dempingsgolven' tussen 1865-1872 en 1881-1885 heel wat stadswater in vooral de historische binnenstad was verdwenen werd de aandacht in de derde dempingsgolf tussen 1889 en 1895 weer op de grachten van de Jordaan gericht" (Rooijen, 1995, p. 16).

${ }^{68}$ Polak schrijft ook dat hij het jammer vindt dat hij de tekst van de heiliederen niet meer heeft kunnen achterhalen. Dankzij een tip van prof. dr. Petra van Dam (VU) heb ik inmiddels ontdekt dat de liedbank van het Meertensinstituut (http://www.liederenbank.nl/) meer dan 40 verwijzingen bevat naar heiliederen, waarvan sommigen met geluidsopname. Deze opnames laten horen hoe de geïnterviewde personen zich de liederen herinneren, maar niet hoe ze geklonken moeten hebben bij het heien. Het merendeel van de teksten liegt er overigens niet om: het heien wordt onomwonden geassocieerd met de geslachtsdaad en de heipaal met een penis.

${ }^{69}$ Stoomboten en zeilboten zijn vooral te vinden op het IJ. Verder is het vooral een kwestie van slepen, roeien en bomen om met een vaartuig vooruit te komen.
} 
Andere geluiden die men in de hele stad hoort zijn het kleppen van de nachtwacht en het geluid van klokken. In de periode 1878 - 1882 verdwijnen de nachtwachten geleidelijk uit de stad. Voor die tijd is de stad ingedeeld in 5 politiebureaus die op hun buurt 25 bewakingskringen omvatten die 'kwartieren' worden genoemd. In elk kwartier surveilleren 2 nachtwachten, die elk half uur de tijd aangeven, maar niet meer zoals vroeger alarm slaan bij brand. ${ }^{70}$

Precies 10 uur 's avonds kwamen de nachtwachts op en deden dienst tot den volgenden morgen 6 à 7 uur. Zij waren voorzien van een ratel en op elk heel en half uur hadden zij hun uurroep te verrichten: 'half elf heit de klok, de klok heit half elf'. (...) Voor zij hun eigenlijke ronde aanvingen liepen zij langs de huizen en terwijl zij er flink op los ratelden riepen zij: 'de wacht om een turfje.' (...) Naar oud gebruik moesten zij dan van de bewoners der gracht een turfje krijgen (Batelt, 1912, p. 49).

Ten tijde van de nachtwachten geeft in ieder geval ook de Oudekerkstoren de tijd aan, maar afgaande op het volgende citaat is dit bij andere klokken en carillons waarschijnlijk ook het geval. "Het 2e deel van de Kalverstraat eindigt bij de Munt, die ieder kwartier met zijn beiaard die van het Koninklijk Paleis van repliek dient. De Carillons zijn al een drietal eeuwen een van de passies van Amsterdam" ${ }^{\text {71 }}$ (Havard, 1876, p. 462). Ook Justus van Maurik hoort vanuit zijn warme bed de verre geluiden van andere klokken. De vier grote luidklokken van de Oudekerkstoren worden niet alleen geluid om de stadsbewoners naar de kerkdienst te roepen, maar ook bij brand en ander gevaar. Bij begrafenissen soms wel twee uur lang. ${ }^{72}$ Ook bij officiële gelegenheden als de verjaardagen van leden van het koninklijk huis worden de klokken bespeeld. ${ }^{73}$ En uiteraard ook bij koninklijk bezoek. "Honderdenéén kanonschoten en alle klokken en carillons der stad luidden de majesteit in bij zijn binnenkomst in de stad" (Den Tex, 2009, p. 180).

Een van de klokken is de 'boomklok' die schippers attendeert op het openen en sluiten van de slagboom tussen het Damrak en het IJ. Tussen 1872 en 1877 moet, door

\footnotetext{
70 "Eigenaardig was vooral de nachtwachtdienst bij brand. Zoo spoedig ergens brand ontdekt was, ging de nachtwacht zijn makkers in de omliggende kwartieren al ratelend en brandschreeuwend waarschuwen. Deze gewaarschuwde nachtwachts deden op hun beurt hetzelfde en zoo wist de stad in een ommezien waar de brand was. Het ongewone spektakel bracht dan gewoonlijk een ontzaggelijke massa menschen op de been en daar torenwachters bovendien brandende lantaarns uithingen in de richting waar de brand was, kon iedereen zien welke richting hij uit moest om ook het schouwspel te kunnen gadeslaan" (Batelt, 1912, p. 50). In 1875 is er een nieuwer systeem in werking. "De geheele stad is met onderaardsche telegraafdraden bezet en van afstand tot afstand zijn er brandschellen. Zoodra er nu ergens brand is, wordt dit aan 't huis aangezegd waar de dichtsbijgelegen brandschel is; deze seint het over en terstond weet de geheele brandweer dat er gevaar is en waar het zich bevindt" (Amsterdammer \& Gouw, 1875/1974, pp. 71-72). Zie ook (Coster \& Janson, ca 1879/1998, pp. 27-28; 50).

${ }^{71}$ Zie ook het citaat van Justus van Maurik aan het begin van dit hoofdstuk.

${ }^{72}$ Zie website http://www.oudekerk.nl/oudekerkstoren.html, geraadpleegd op 21 juni 2013.

${ }^{73}$ Archief Secretarie Publieke Werken Amsterdam, inventarisnummer 3976, zaaknummer 4762.
} 
de veranderende situatie als gevolg van het aanplempen van de drie eilanden in het open havenfront voor de bouw van het Centraal Station, het luiden van de boomklok zijn functie hebben verloren.

Hij wees met zijn hand op een rei aan elkander verbonden palen, vlak voor het open havenfront. - Dat zijn de boomen. Daar moeten de schepen voor blijven liggen na en vóór zonsondergang. Als de boomen geopend of gesloten worden, luidt hier de klok. Je hebt toch 's avonds de boomklok wel eens gehoord? Of ik de boomklok kende? 't Was een van mijn beste vrienden. 'k Zat er dikwijls naar te luisteren, 's avonds, als ik, voor 't naar bed gaan, mijn schoolles leerde. Die klok had zoo'n bijzonder mooien, helderen klank, ze luidde zoo vriendelijk en rustig, heel anders dan de zware klok, die soms, als brommend, het uur verkondde (Maurik, 1887/1901, p. 10).

Niet lang na het verdwijnen van de boomklok is er in de binnenstad een nieuw geluid te horen, het loeien van telefoondraden in de wind. ${ }^{74}$ "En over alles heen een net van elkander kruisende draden - als een spinneweb gespannen over de gansche stad; telefoondraden, die fluisteren en zingen, als de wind er tusschen giert, en vertellen, dat Amsterdam een wereldstad is geworden"75 (Maurik, 1887/1901, p. 12).

Wereldstadgevoelens zijn er uiteraard ook tijdens de Amsterdamse wereldtentoonstelling van 1883. Er zijn meer dan honderdduizend mensen op en om het tentoonstellingsterrein (gedeeltelijk samenvallend met het huidige Museumplein) als de tentoonstelling op 1 mei wordt geopend. "Maar allereerst een jubelzang; Een groet, een beê van zegen; Ruischt op den drempel luid u tegen!" klinken enkele regels van de feestcantate aan het begin van de overigens sobere ceremonie. Het is niet waarschijnlijk dat het hele publiek de jubelzang hoort, maar dat mag de pret niet drukken. Vanwege de vele recepties, feesten en soirées zal er gedurende een half jaar een uitbundige stemming in de stad heersen. Toch valt het aantal bezoekers tegen. Op de drukste dagen verschijnen er zo'n 20.000 tot 22.000 aan de kassa, iets minder dan het aantal personen dat twee jaar later per dag de Hartenstraat passeert ${ }^{76}$ (Montijn, 1983, pp. 12-15; 55-56).

\footnotetext{
${ }^{74}$ Dit fenomeen doet zich ook in Antwerpen voor: "De telephoon schijnt te Antwerpen de ingezetenen in hun nachtelijke rust te storen. De talrijke menigte metaaldraden, zoo schrijft men vandaar, vormt een soort van Aeolische harp. Bij de minste bries geraken de draden, hoe goed ook gespannen, in trilling en geven dan, met behulp van de palen, waar langs zij loopen, dien loeiende klank, aan het metaal in het bijzonder eigen. Niet slechts in de woningen waarmede zij onmiddellijk verbonden zijn, maar tot zelfs in den omtrek wordt dit geruisch vernomen en wekt daar menigeen aanhoudend uit den slaap (Algemeen Handelsblad, 14-071880).

${ }^{75}$ Ondanks het protest tegen de palen, onder meer omdat ze lelijk worden gevonden, zullen deze pas na de eerste wereldoorlog definitief verdwijnen (Rooy, 2006a, p. 528).

${ }^{76}$ Archief Secretarie Publieke Werken Amsterdam, inventarisnummer 144, zaaknummer 1861.
} 


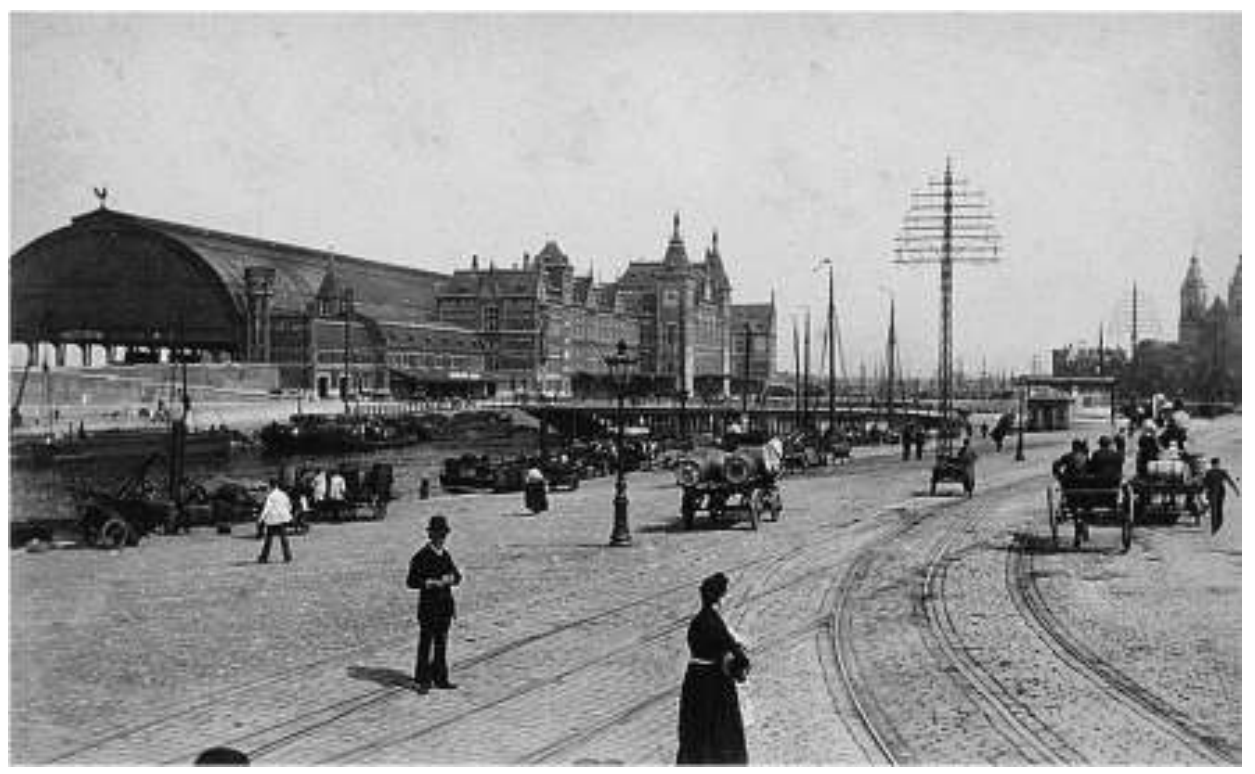

Afbeelding 5: Telefoonmasten op de Prins Hendrikkade ca 1890, links het Centraal Station (Stadsarchief Amsterdam)

Tegenpool van het tijdelijke 'gedruisch' van de uiteindelijk ook in financiële zin niet zo succesvolle Wereldtentoonstelling, is het geluid van de Beursklok die jaar in jaar uit het ritme aangeeft van de bedrijvigheid op en rond de Dam. ${ }^{77}$ "Doch hier zijn we aan de beurs. 't Beursklokje houdt kwart voor tweeën op met luiden, gaan we de trappen op, en maken we dat we binnen zijn, anders hebben we een kwartje boete" ${ }^{\prime 78}$ (Amsterdammer \& Gouw, 1875/1974, p. 58).

$\mathrm{Er}$ is echter nog een gebruik bij de Amsterdams Beurs dat met geluid te maken heeft, het zogenaamde 'trommelen op de beurs'. Dit gebruik, dat dateert uit de tijd van de Beurs van Hendrick de Keyser (afgebroken in 1835), werd afgeschaft met de ingebruikname van de Beurs van Berlage in 1903. "Een oud recht hebben te Amsterdam de jongens op de Beurs. Gedurende de kermis mogen ze de geheel week er naar hartelust trommelen. Dat is nog afkomstig van een weesjongen, die, volgens de overlevering, een buskruitverraad onder de oude beurs (welke op 't Rokin stond) zou ontdekt hebben, ter belooning waarvan hij dat recht van den Magistraat verzocht en voor hem en alle Amsterdamsche jongens tot in eeuwigheid zou verkregen hebben.

\footnotetext{
77 De beursklok heeft een lange geschiedenis. In het in 1844 verschenen boekje Physiologie van Amsterdam, door Een' Amsterdammer staat de volgende beschrijving: "Ziet den Amsterdamschen koopman, den makelaar, den kantoorbediende, den kruijer, den kantoorlooper; met welk eene drukte, met wat al gewoel verdringen zij elkander in de donkere Kalverstraat en in de nog donkerder stegen, die naar de beurs leiden, wanneer de beursklok luidt (de Vries, 1844, p. 8).

${ }^{78}$ Deze 'boetes' komen ten goede aan de armlastigen in de stad.
} 
(...) Ge kunt u't onharmonische en oorverscheurende geweld niet voorstellen, hetwelk er dan heerscht" (Amsterdammer \& Gouw, 1875/1974, p. 63).

Op dien ochtend, toen ik de Nieuwe Kerk uitkwam en den Dam (het voornaamste plein der stad) overstak, was ik verwonderd de Beurs vol jongens te zien, en van daar een geluid van pret en gelach, geschreeuw, hoera-geroep, trommels, trompetten, fluiten en schelle zakfluitjes te hooren voorkomen, zoo als ik nog nooit had vernomen of mij had kunnen voorstellen, en zooals ik vurig hoop nimmer weder te zullen hooren. In een oogenblik van afdwaling van geest, liep ik de Beurs op. Alle gedeelten van het groote gebouw waren tot stikkens toe vol dreumissen. Honderden bij honderden gilden en schreeuwden zoo hard als hunnen Hollandse stemmen maar konden, trommelden en bliezen op akelige trompetten, holden rond als kleine duivels, en rammelden met hunne rateltjes achter den rug van de onvoorzichtigen, die de vermetelheid hadden zich in hun midden te wagen (Wood \& Baarslag, 1878/2002, p. 69).

Tot slot kan niet onvermeld blijven dat Amsterdam in het laatste kwart van de negentiende eeuw in sociaal politieke zin een woelige hoofdstad is en bij oproer hoort natuurlijk geluid. "De winters van $1884 / 85$; 1885 /86 en $1886 / 87$ geven woeste tooneelen te aanschouwen. Bij duizenden trekken de werkeloozen langs Heeren- en Keizersgrachten. Voor het eerst ontstaan vereenigingen van werkeloozen, die groote beroering in de stad veroorzaken" (Rodrigues de Miranda, 1921, p. 58). Oproer in Amsterdam gaat bijna altijd gepaard met glasgerinkel op de grachten. Men trekt via de Dam naar de Herengracht om daar de ruiten in de gooien. Bij voorkeur die van de burgemeester (Rooy, 2006b, p. 479). Zo gebeurde het ook tijdens het Kermisoproer in 1876. "Zooals het meer gebeurt begonnen de relletjes door kinderen. Troepen kinderen trokken door den Jordaan zingende: 'kermis mot er wezen, kermis mot er zijn.' Al spoedig sloten de respectievelijke Pa's en Ma's zich daarbij aan, zoodat het op het laatst een stoet werd, die overal ruiten ingooiend en straatschandaal plegend, door de stad trok" (Batelt, 1912, pp. 83-84). Het Palingoproer in 1886 speelt zich af in de Jordaan. Het blijft nu echter niet bij glasgerinkel, maar er klinken ook geweerschoten en er vallen meer dan twintig dodelijke slachtoffers (Rooy, 2006b, pp. 476-479).

\section{Buiten de 'gehoorzone', binnen de tekst: Nieuwe betekenissen van geluid}

De voorgaande inventarisatie van het geluid van de 'Woelige Wereldstad' is deels gebaseerd op waarnemingen die door tijdgenoten vroeger of later op papier zijn gezet, en deels op extrapolaties van gegevens over gebeurtenissen, patronen van activiteiten, vormen van bewoning en eigenaardigheden van het dagelijks leven in die tijd. Zonder 
deze extrapolaties valt een deel van het eind negentiende-eeuwse klanklandschap buiten de 'gehoorzone' omdat tijdgenoten niet over alle geluiden die ze horen geschreven hebben. In het resterende deel van dit hoofdstuk staat echter de betekenis en waardering van geluiden centraal en daarom ligt vanaf nu de nadruk op geluiden waarover wel geschreven is en waarbij het bovendien gaat om teksten uit het einde van de negentiende eeuw. ${ }^{79}$ Werden deze geluiden meer betekenisvol, bijzonder, gangbaar, ergerlijk of mooi gevonden dan andere geluiden? Of zijn er andere redenen waarom wel regelmatig geschreven wordt over het geratel van de karren, maar niet over het geraas van de stoommachine?

\section{Wetenschap van en woorden voor geluid aan het eind van de negentiende eeuw}

Voordat wordt ingegaan op de betekenis van de geluiden voor de bewoners en bezoekers van de 'Woelige Wereldstad', staan we nog even stil bij de primaire teksten die voor dit onderzoek zijn gebruikt. Zoals in het tweede hoofdstuk al is aangegeven zijn dat krantenartikelen over geluid uit de periode 1875-1895 aangevuld met reisverslagen, impressies van het leven in de stad en stukken uit het gemeentearchief (raadsverslagen, interne memo's, processen verbaal, klachtenbrieven). ${ }^{80}$ Van de in totaal 140 gebruikte krantenartikelen zijn er 83 afkomstig van het Algemeen Handelsblad en 57 van Het nieuws van den dag: kleine courant. ${ }^{81}$

\footnotetext{
${ }^{79}$ Herinnering aan geluiden die later zijn opgetekend dan de periode waarop ze betrekking hebben zijn enkel gebruikt in het voorgaande deel van dit hoofdstuk. Het betreft vier publicaties uit het interbellum, één uit 1912 en een dagboekfragment uit 1958 (Den Tex) waarin de schrijver herinneringen ophaalt aan het eind van de negentiende eeuw (Batelt, 1912; Den Tex, 2009; Kluytenaar, 1936; Polak \& Vlugt, 1936; Rodrigues de Miranda, 1921; Timmerman, 1938).

${ }^{80}$ Helaas hebben de stukken uit het gemeentearchief Amsterdam enkel bijgedragen aan de conclusie dat indien er al klachten of bezwaren werden geuit, deze bijna nooit betrekking hadden op geluid. Het Archief van de Secretarie der Publieke Werken (toegangsnummer 5180) bevat interne memo's, processen verbaal (= verslaglegging van hoorzittingen) en klachtenbrieven die te maken hebben met aanvragen en toekenningen van Hinderwetvergunningen. In een totaal van 1461 stukken (290 uit januari 1875; 320 uit februari 1876, 427 uit juli 1894 en 414 uit augustus 1895, zijnde telkens 5\% van het jaartotaal) zijn 12 stukken gevonden waarin geluid potentieel een rol had kunnen spelen (smederijen, venters, koperslagers). Toch wordt geluid niet genoemd in de betreffende dossiers. Dit resultaat stemt overeen met de observatie van Floor Fokkert, in 2010 binnen Stadsarchief Amsterdam degene met de meest inhoudelijke kennis van historische Hinderwetdossiers. De klachten uit de periode 1875-1895 die zij in Hinderwetdossiers is tegengekomen hadden "eerder betrekking op bijv. stankoverlast van een viswinkel dan van lawaai. De hele binnenstad zat rond die tijd nog vol met bedrijfjes en overdag was hier uiteraard lawaai, als de mensen hier last van hadden lijkt het mij waarschijnlijk dat ze 'oom agent' inseinden en dat deze misschien een reprimande kon geven. Weerslag van dergelijke taferelen lijkt mij moeilijk te vinden in documentatie uit die tijd" (email d.d. 24 november 2010).

${ }^{81}$ Het betreft artikelen uit de jaargangen 1875, 1880, 1889, 1891, 1894 en 1895. Dit zijn de jaargangen die medio 2011 beschikbaar waren in de databank Historische Kranten. De 140 artikelen zijn vanwege hun inhoudelijke relevantie geselecteerd uit een totaal van 3191 artikelen waarin een (combinatie) van de volgende woorden en tekenreeksen minimaal één keer voorkomt: 'geluid', 'geluid*', 'geluid van', 'geraas',
} 
We hebben ook eerder vastgesteld, dat deze teksten niet door vrouwen, kinderen, arbeiders en armlastigen zijn geschreven en dus enkel de visie weergeven van een kleine elite. Maar het is ook deze elite die een centrale rol speelt in het dominante discours over geluid in deze tijd. Bovendien zijn ook zij gebonden aan en beïnvloed door in hun tijd gangbare praktijken, opvattingen en de conventies van taal, van (beschrijvende) literatuur en het genre waarin zij schrijven. Als auteurs van reisverhalen bepaalde geluiden in de stad vaak noemen, zegt dit minstens zoveel over tijdgebonden stereotypen binnen dat genre als over aard en intensiteit van het geluid zelf. En op hun beurt zijn schrijvers van klachtenbrieven gebonden aan gangbare uitdrukkingen voor geluid, lawaai, overlast etc. Door te focussen op de manier waarop over Amsterdamse geluiden is geschreven (of gezwegen) tegen de achtergrond van de maatschappelijke en technologische ontwikkelingen in die periode, ontstaat zicht op de interpretaties, meningen en ideeën over deze geluiden die in ieder geval wordt gedragen door het schrijvende en lezende deel van de bevolking.

Ten eerste komt geluid als fenomeen aan de beurt, dat wil zeggen de manier waarop in deze tijd over het verschijnsel geluid werd gedacht, ernaar werd geluisterd, ermee werd geëxperimenteerd en de materialisatie van deze experimenten in allerlei nieuwe apparaten. Dat kader hebben we nodig om de tekstfragmenten over stadsgeluid te kunnen duiden. Want zoals Sterne zo overtuigend in zijn boek The Audible Past beargumenteert: ook definities van geluid zijn context-afhankelijk. "Sound is an artefact of the messy and political human sphere" (Sterne, 2003, p. 13). Dit impliceert onder meer dat we ons ervan bewust moeten zijn, dat inwoners en bezoekers van Amsterdam in het laatste kwart van de negentiende eeuw andere betekenissen toekennen aan bepaalde geluiden, daarvoor andere woorden gebruiken en ook op een andere wijze luisteren dan wij nu voor vanzelfsprekend houden.

In de loop van de negentiende eeuw verandert de manier waarop binnen de fysica, akoestiek, fysiologie en otologie (oorheelkunde) over geluid wordt nagedacht ingrijpend. Wij zijn eraan gewend om het maken van muziek op te vatten als een van de vele vormen van geluidproductie, maar dat is een manier van denken die pas aan het einde van de negentiende eeuw ingang heeft gevonden. Voor die tijd werd er, onder meer op basis van de harmonieleer van Pythagoras en de veronderstelde regelmatigheid dan wel onregelmatigheid van geluidsgolven, uitgegaan van een wezenlijk onderscheid tussen muziek en alle andere geluiden. Muziek wordt gekenmerkt door regelmatigheid en harmonie, alle andere geluiden staan voor onregelmatigheid en disharmonie. De publicatie van het werk van Helmholtz in 1863 speelt een belangrijke rol in het opheffen van deze fundamentele tegenstelling tussen muziek en niet-muziek, door diens revolutionaire verklaring voor het optreden van consonanten en dissonan-

'gedruisch', 'loei*', 'ratel*', klok*', luidruchtig', 'burengerucht', 'rumoer', straatrumoer', 'lawaai', 'herrie', 'klinken', 'geratel' en 'geloei'. Het woord 'straatlawaai' heeft geen relevante artikelen opgeleverd. 
ten. Muziek en geluid sluiten elkaar nu niet langer uit, maar behoren samen met spraak en lawaai tot hetzelfde domein (Rieger, 2003, pp. 183 - 189).

Zolang het onderscheid tussen muziek en niet-muziek uitgangspunt is, vormen de stem, de mond, muziek en muziekinstrumenten de meest belangrijke objecten voor onderzoek naar geluid. Dit wordt treffend geïllustreerd door de verbazing van de medewerkers van het populair wetenschappelijke tijdschrift Scientific American die in 1877 aanwezig waren bij Edisons demonstratie van de fonograaf. "After getting over their initial astonishment, witnesses reported that they were most fascinated by the sheer simplicity of the machine, 'a little affair [made] of a few pieces of metal' rather than the complicated electric and mechanical contrivance with 'rubber larynx and lips' they might have imagined" (Gitelman, 1999, pp. 21-22). Het voorbeeld laat zien hoe sterk het denken over geluid verbonden is met de bron van geluid en hoe in dit geval aan de menselijke stem, het meest verheven muziekinstrument, een vanzelfsprekende rol bij het weergeven van spraak en zang wordt toegedacht.

Naast het feit dat bij deze visie op het fenomeen geluid de aandacht vooral uitgaat naar muziek, muziekinstrumenten en stemmen en de daaraan toegekende harmonische en regelmatige kwaliteiten, wordt geluid dat men liever niet wil horen in verband gebracht met een gebrek aan orde, beschaving en 'fatsoen' bij de veroorzaker van dat geluid. Die relatie werkt op meerdere niveaus. In de eerste plaats gaan klachten over geluid vaak samen met ongenoegen over het onbehouwen, onfatsoenlijke en onzedelijke gedrag van 'het gemeen' dat in de negentiende-eeuwse standenmaatschappij als de belichaming van onbeschaafdheid wordt gezien. Het is niet de bedoeling dat het gewone volk zich zo nadrukkelijk laat horen. Het heeft de plicht gehoorzaam te zijn, af te wachten en eerbied te tonen (Woud, 2010, p. 57).

"En 't Amsterdamsche gemeen?" "Is van oudsher zoo erg als er maar zijn kan," hervatte ik. "Trouwens, men wil, dat dit aan groote steden eigen is. Echter kunt ge $u$ slecht een denkbeeld van de gemeenheid der mindere klasse maken. Achting voor fatsoenlijke standen is er niet. Als er kinderen op uw stoep spelen en ge verbiedt het hun, schelden ze u uit en ontzien zich niet, hun tong tegen u uit te steken. Er moet maar een vreemdeling komen, die wat excentriek gekleed is - hij wordt familjaar uitgejouwd." (...).Nog maakt de mindere klasse hier een feestdag van den Pinkstermaandag, die echter ook al van jaar tot jaar zich slechts tot het gemeen bepaalt. Dan gaat men 's morgens vroeg naar de Diemermeer, wat men "dauwslaan" noemt en waar 't heele vermaak bestaat in elkander te zien en zich braaf dronken te drinken; zoodat men des middags in de Plantage troepen volks ontmoet, die 'braaf vet' en zingende en joelende huiswaarts keeren (Amsterdammer \& Gouw, 1875/1974, pp. 73, 138-139).

Bovendien worden de stemmen van 'onbeschaafde' groeperingen of volken vaak per definitie lelijk en hinderlijk gevonden, zoals het volgende voorbeeld van de Brit Wood - 
die nogal neerkijkt op Nederland - illustreert: "Deze vereerders van Bacchus liepen, in groepen van zes of twaalf, te zingen en te schreeuwen, zoo hard als zij konden, met stemmen zooals slechts aan de onbeschaafdste klassen eigen kunnen zijn, of zooals alleen de Hollanders bezitten" (Wood \& Baarslag, 1878/2002, p. 55).

En tenslotte wordt het zingen ook gezien als een lichamelijke, emotionele en irrationele handeling die eigen is aan het primitieve 'gemeen', het nog onontwikkelde kind en de over-emotionele vrouw, terwijl de sprekende stem geassocieerd wordt met mannelijkheid, volwassenheid en discipline. Zingen op straat geldt zelfs als het enige wapen van het verder stemloze 'mindere volk' (Hoegaerts, 2010, pp. 192-195). In dat verband past ook het gegeven dat aan de vergunningen die in Amsterdam nodig waren voor het geven van vertoningen en het maken van muziek op straat - ik kom daar nog op terug - tot 1897 ook een censuurbepaling verbonden was die ervoor moest zorgen dat alleen gezegd, gezongen en vertoond werd wat door de burgemeester en de hoofdcommissaris van politie was goedgekeurd. Die censuurbepalingen gaven het gezag de mogelijkheid om controle uit te oefenen op de uitingen van de straatartiesten waarvoor het beschaafde deel van de bevolking zijn neus toch al ophaalde.

Mede onder invloed van het werk van Helmholtz verschuift in de loop van de negentiende eeuw de aandacht voor de bron of oorsprong van geluid naar haar effect en gaat in het onderzoek naar geluid de belangstelling uit naar het oor en het horen. Het vermogen van het oor om trillingen om te zetten naar een andersoortig signaal, gaat dan ook een centrale rol spelen in het denken over en experimenteren met geluid en allerlei nieuwe vormen van geluidreproductie (Sterne, 2003, pp. 31-85).

Veel van deze 'uitvindingen' komen in het laatste kwart van de negentiende eeuw via de krant onder de aandacht van het publiek. De krant zelf maakt in deze periode echter ook een enorme ontwikkeling door. Na het afschaffen van het dagbladzegel in 1869 groeit het aantal kranten sterk, neemt geleidelijk het aantal pagina's toe en breidt ook het scala aan onderwerpen uit. Naast de nieuwsvoorziening en het duiden van het nieuws, bieden de kranten nu een discussiepodium en zorgen ze ook voor aangename verpozing (Broersma, 2002, pp. 260-262). Verder bestaat het fenomeen 'bladvulling' uiteraard in deze tijd ook al. Sommige berichten over nieuwe technische ontwikkelingen, zoals kinderboeken met dierengeluiden, roepen dan ook de vraag op of dergelijke boeken werkelijk geproduceerd kunnen worden en bestaan, of dat het om een fantasievolle bladvulling gaat. Desondanks geven ook dit soort berichten zicht op onderwerpen en ontwikkelingen waarvoor men belangstelling heeft.

Vooral de phonograaf van Edison spreekt tot veler verbeelding en leidt tot uitgebreide besprekingen van dit apparaat in de krant. ${ }^{82}$ Dankzij dit apparaat dringt ook, zij het vooral in indirecte zin en heel geleidelijk, de nieuwe visie op geluid en muziek door bij het grote publiek (Rieger, 2003, p. 193). Tegelijkertijd blijkt uit de manier

\footnotetext{
82 Zie bijvoorbeeld de artikelen 'De Phonograaf ' en 'Nog eens Tom Edison - En hoe men in Engeland zijn donder steelt', in Het nieuws van den dag: kleine courant, 21-05-1878 resp. 04-07-1878.
} 
waarop geluidsbronnen in beschrijvingen van demonstraties van de phonograaf aan de orde komen, hoe sterk het onderscheid tussen muziek en niet-muziek nog verankerd zit in het denken.

Het bewonderenswaardigste van zijne machine is, dat zij zoo eenvoudig is dat het niet moeielijk is haar te begrijpen. Het is genoeg om te zeggen, dat men spreekt of geluid geeft, welk ook, in een cylinder. Het gehoorvlies aan het einde neemt het geluid op en een naald teekent het geluid af op een zeer fijne rol bladtin. Aan de machine is een slinger (...) dien men draait terwijl men spreekt. Draait men hem naar de eenen kant, dan werkt de lucht op het gemerkte tin en gaat aan de andere zijde door eene soort van trechter uit, en het geluid herhaalt zich! Elk geluid, van welken aard ook, wordt duidelijk teruggegeven. Het komt er niet op aan of het een muzikale noot is, de hoest van een oud man, het zoete kwinkeleren van een Patti, het luide geblaf van een hond of de schreeuw van een papegaai, als het eenmaal geschreven is op het tinblad van de phonograaf, kan het herhaald worden zoo dikwijls men wil ('De Phonograaf', Het nieuws van den dag: kleine courant, 21-051878).

In de periode 1877 - 1895 verschijnen er naast berichten over de phonograaf ook artikelen over noviteiten als de 'spreektelegraaf', de 'fotofoon', de 'topophoon', de fluitboei, de sonometer, de 'phoneidoskop', het kleurenorgel, een mijngasdetector op basis van geluid, de microfoon en over een kinderboek met dierengeluiden. ${ }^{83}$ De 'spreektelegraaf' is een telefoon die geluidstrillingen met behulp van inductie omzet in elektrische signalen. "De indruk van het gesprokene of gezongene is, alsof iemand in een benedenvertrek spreekt en een ander door den vloer heen toehoort - zuivere spraak uit de onderwereld." ${ }^{84}$ De 'fotofoon' zet geluid om in elektrische signalen met behulp van selenium en een lichtstraal. Met de 'topophoon' of 'plaatsklinker' (twee grote hoorns aan weerszijden van de schouders van de luisteraar die via rubber slangen met de oren zijn verbonden) kan de positie van een geluid in dichte mist bepaald worden, bijvoorbeeld van een fluitboei. De fluitboei op zijn beurt, maakt gebruik van de deining van de zee om geluid voor te brengen. De 'sonometer' is een audiometer, een apparaat dat ook op basis van inductie werkt en waarmee men op een schaal van 0 tot 200 'graden' kan meten hoe goed men het tikken van een uurwerk hoort. De invloed van geluidstrillingen op de kleuren in een zeepbel worden zichtbaar gemaakt met een 'phoneidoskop' en het kleurenorgel tenslotte, koppelt de tonen binnen een octaaf aan het kleurenspectrum en visualiseert zo muziek. "Op het orgel opent men met de toetsen 14 kijkgaten door welke in een duistere zaal de overeenkomstige

\footnotetext{
${ }^{83}$ Algemeen Handelsblad, 22-07-1880, 29-07-1880, 04-10-1880, 10-12-1880, 16-01-1894, 21-01-1894 en $14-$ 06-1895; Het nieuws van den dag: kleine courant, 25-11-1877, 21-05-1878, 26-05-1878 en 13-07-1879.

84 'Gemengde zaken: De spreek-telegraaf', Het nieuws van den dag: kleine courant, 25-11-1877.
} 
kleuraccoorden op een wit scherm worden opgevangen. Zoo werd o.a. een stuk van Chopin in kleuren voorgesteld, wat volgens een toeschouwer uiterst vermoeiend voor de ogen was." ${ }^{\prime 85}$

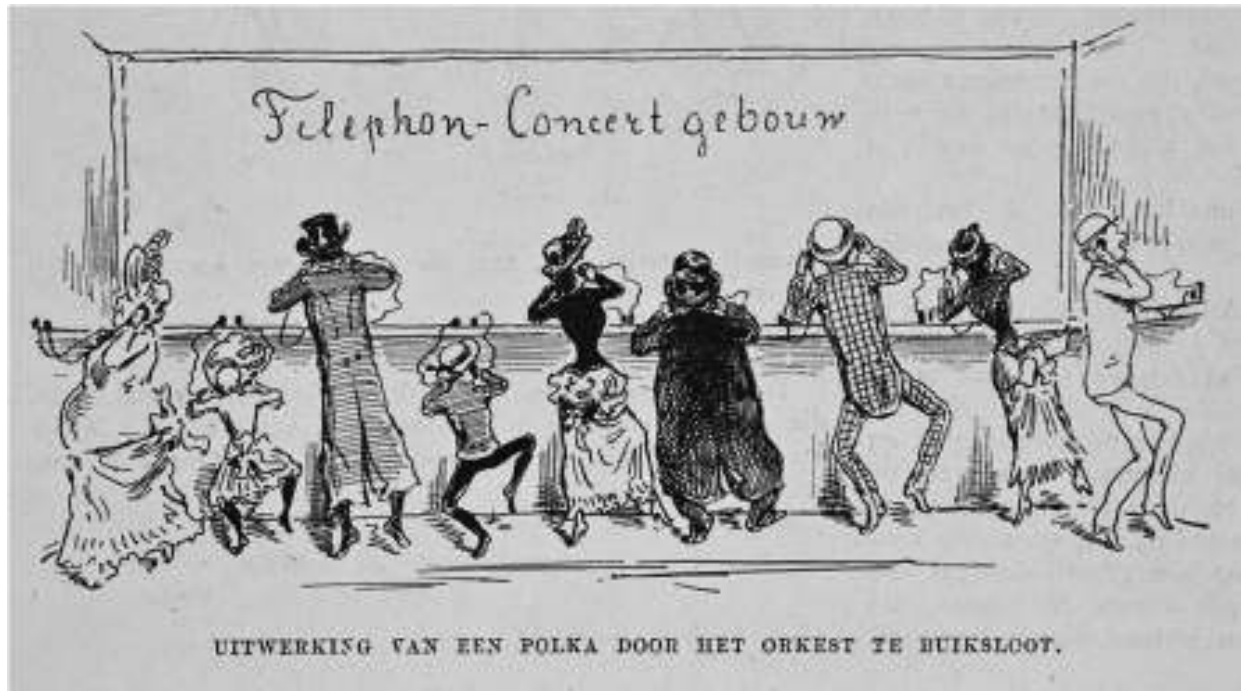

Afbeelding 6: "Uitwerking van een polka door het orkest te Buiksloot", tekening (ca 1883) die de gevolgen verbeeld van het luisteren naar (dans)muziek via een koptelefoon (Atlas van Stolk)

Maar het blijft niet bij krantenberichten alleen. In 1880 wordt in Amsterdam de eerste concessie toegekend voor de exploitatie van telefoonlijnen. Men ziet dan vooral zakelijke gebruiksmogelijkheden op gemeente niveau. Bij de beëindiging van deze concessie in 1895, gaat men echter al uit van een nationaal telefoon netwerk. Verder biedt de Bell-telephoon-maatschappij op de wereldtentoonstelling in 1883 in een eigen gebouwtje op het tentoonstellingsterrein een bijzondere ervaring aan het publiek. "Hier konden honderd verbaasde luisteraars tegelijk voor een luttel bedrag muziek-uitvoeringen horen die op heel andere plaatsen in de stad werden gegeven. $\mathrm{Er}$ waren zelfs speciaal hiervoor kabels over de bodem van het IJ gelegd, om concerten over te brengen uit de muziektent bij de uitspanning het Tolhuis, helemaal in Buiksloot" (Montijn, 1983, p. 44).

Het revolutionaire karakter van deze noviteiten wordt pas duidelijk wanneer we ons realiseren dat er in dezelfde periode ook krantenartikelen verschijnen over proefnemingen binnen de Duitse marine over het geluid van hoorns versus vuurpijlen ${ }^{86}$ of over een discussie binnen het Franse leger over het gebruik van trom of trompet op het slagveld.

\footnotetext{
85 'Een kleurenorgel', Algemeen Handelsblad, 14-06-1895.

${ }^{86}$ Algemeen Handelsblad, 21-07-1880.
} 
Voorts kan de trom niet op een verren afstand gehoord worden; als zij vochtig is, geeft zij in 't geheel geen geluid, en in elk geval zijn de signalen door haar gegeven moeilijk te verstaan. (...) De vrienden van de trom voeren daartegen aan, dat dit instrument in het geraas van den strijd duidelijker en op grooter afstand gehoord kan worden dan trompetten, en dat de manschappen meer opgewekt zullen worden door tromgeroffel dan door de zwakke en onzuivere tonen van een trompet (Het nieuws van den dag: kleine courant, 29-03-1880).

Verder wordt ook in de krantenberichten over andersoortige technische snufjes als 'luchtspoorwegen', 'waterspoorwegen', 'stoomtramwagens', stoomwaschmachines', 'gas-moteurs' en 'gasgloeilicht' steeds ook aandacht besteed aan (het ontbreken van) geluid. Het berijden van de luchtspoorweg zal "weinig gedruisch veroorzaken". De waterspoorweg, waarvan de wagons worden aangedreven door waterkracht terwijl ze over een waterfilm glijden, is bijzonder geschikt "voor luchtspoorwegen in de steden. Want het geeft geen rook, maakt geen geraas en staat geheel onder bedwang." En in de stoomtramwagen die in Berlijn beproefd kan worden is "de beweging die bij het rijden wordt veroorzaakt zoo gering, dat men zonder hinder schrijven kan; ook is het gedruisch veel minder dan van een droschke." Tenslotte verschijnen er ook, zoals eerder al genoemd, legio artikelen over nieuw bestratingsmateriaal tegen hinderlijk 'geraas en gedruisch'. ${ }^{87}$

Samenvattend: de concepten en modellen waarmee over geluid wordt nagedacht en geschreven ondergaan een ingrijpende wijziging in de loop van de negentiende eeuw. Ze zijn het gevolg van en leiden tot allerlei technologische vernieuwingen op het gebied van geluid. ${ }^{88}$ Via de krant maar ook aan den lijve wordt men in Amsterdam met deze veranderingen geconfronteerd. Naast de nouveautés op het gebied van geluid die op de wereldtentoonstelling te zien zijn, verdwijnen geluiden die lange tijd onderdeel uitmaakten van de stedelijke communicatiestructuur, zoals de boomklok en het kleppen van de nachtwacht of zij worden vervangen door "een vernuftig systeem van electrische brandmelders, die in overvloed in alle delen van de stad staan opgesteld." (Coster \& Janson, ca 1879/1998, p. 28). Ook ontwikkelt zich een levendige belangstelling voor verkeersmiddelen die minder geraas maken en voor 'noiseless pavement'. Straten worden mondjesmaat geasfalteerd of van een houten bestrating voorzien en dus stiller. En er is zelfs incidenteel aandacht voor geluiddemping bij machines:

\footnotetext{
${ }^{87}$ Algemeen Handelsblad, 01-02-1875, 22-08-1880, 04-11-1880, 25-07-1889 en 07-01-1895; Het nieuws van den dag: kleine courant, 31-05-1877, 01-12-1877, 08-05-1879 en 23-09-1877.

${ }^{88}$ Ontwikkelingen in het denken over geluid en de fabricage van nieuwe geluidapparaten worden bovendien beïnvloed door en beïnvloeden op hun beurt het denken over gesproken en geschreven taal (Gitelman, 1999).
} 
Gelukkig begint men in beschaafde steden overal den oorlog te verklaren aan al dat noodelooze geraas en geweld, dat alle gesprekken op straat en rustig werk in kamers, die op straat uitzien, moeilijk maakt, terwijl het zieken en zwakken op onduldbare wijze martelt. Een nieuwe uitvinding moet daartoe medehelpen. Justice's Quieting Chambre is de naam van deze heerlijke geluid-stikker, die het geraas der pijpen van stoommachines verdooft (Algemeen Handelsblad, 04-11-1880).

Tegelijkertijd weten we dat aan het eind van de negentiende eeuw de bevolking en de bedrijvigheid in de stad toenemen, dus het kan niet anders dan dat er allengs meer geluid wordt voortgebracht.

Verder is het van belang om stil te staan bij de negentiende-eeuwse woorden voor geluid. Voor het tegenwoordige 'lawaai' en 'herrie' gebruikte men toen 'geraas' of 'gedruisch', terwijl lawaai en herrie destijds vooral verwijzen naar (het uiten van) 'onenigheid'. Ook het woord 'rumoer' werd vaak gebruikt in de betekenis van onenigheid of het uiten van ongenoegen en 'straatrumoer' voor openbare protestacties. Tegenwoordig zouden we daarvoor de woorden 'demonstratie' of 'volksoploop' gebruiken. Het woord 'straatrumoer' heeft een overwegend negatieve connotatie en benadrukt vooral het opruiende karakter van de activiteit. 'Luidruchtig' wordt doorgaans in de vorm van luidruchtig protest, bijval of luidruchtige vijanden gebruikt en in krantenartikelen wordt het woord 'burengerucht' in verband gebracht met feestlokalen, dronken mensen, ongewenste straatmuziek, maar soms ook met bedrijvigheid. Dit laatste in tegenstelling tot wat een proefschrift uit 1888 vermeldt over de term 'burengerucht' in het Wetboek van Strafrecht, dat de term koppelt aan het woord 'rumoer' en verder benadrukt dat "hier zoodanig gedruisch wordt verstaan dat niet middel tot of gevolg van geoorloofde werkzaamheden of uitspanningen is, maar om zichzelf uit baldadigheid, veroorzaakt wordt" (Dam, 1888, p. 40).

Het woord 'geluid' tenslotte, wordt gebruikt voor geluid als natuurkundig verschijnsel maar komt vooral veel voor in recensies van concerten, vooral bij zang (hij/zij heeft een mooi geluid). Wij gebruiken voor gelijksoortige beschrijvingen tegenwoordig het woord 'stem'. ${ }^{89}$ Dit tweevoudig gebruik van het woord 'geluid' laat mooi zien hoe oude en nieuwe concepten voor 'geluid' tegelijkertijd deel uitmaken van de taal en daarmee ook van het gangbare gedachtegoed. 'Geluid' als natuurkundig verschijnsel past bij het nieuwere denken in termen van het effect van vibraties en van de werking van het oor. 'Geluid' als stem daarentegen hoort bij concepten over geluid in termen van muziek versus niet-muziek en de mond of muziekinstrumenten als ideaaltypische bronnen van geluid. Bij dit oudere concept (geluid als muziek) speelt de kwaliteit van

\footnotetext{
${ }^{89}$ Deze analyse van gebruikte woorden en hun betekenis is gebaseerd op een analyse van artikelen uit het Algemeen Handelsblad; De Tijd; Het nieuws van den dag: kleine courant en de Nieuwe Rotterdamsche Courant uit de periode 1875-1895 voor zover digitaal beschikbaar in de verzameling Historische Kranten van de KB. Zie website http://kranten.kb.nl/.
} 
geluid een grote rol; een geluid is mooi of lelijk, muzikaal of niet-muzikaal, zuiver of onzuiver.

\section{Hoe wordt geluid beschreven en beoordeeld?}

De mix van oude en nieuwe concepten komt uiteraard niet alleen tot uiting in de betekenis verbonden aan woorden, maar ook in de wijze waarop over geluid wordt nagedacht en geschreven. Het artikel over de phonograaf, waarin de verbazing wordt uitgesproken over het vastleggen van zowel muziek als andere geluiden, is daar een mooi voorbeeld van. Enerzijds gaat het over geluid als trillingen die via het trommelvlies worden omgezet naar tekens op een rol bladtin en anderzijds is men verbaasd dat zowel zingen (muziek) als hoesten (niet-muziek) door de phonograaf wordt geregistreerd.

Zoals eerder al is aangegeven, is het geluid van stemmen, klokken, carillons en wagens die over de keien ratelen de grootste gemene deler in de reisverhalen van buitenlanders en in de publicaties van Amsterdammers die in de periode 1875 - 1895 geschreven zijn. In krantenartikelen en ingezonden brieven over stadsgeluiden, is er iets meer variatie aan geluiden, maar ook hier nemen het geraas van rijtuigen en menselijke stemmen een belangrijke plaats in en is er weinig aandacht voor het geluid van stoommachines en geluidsintensieve nijverheid.

De nadruk op het geluid van stemmen, klokken en carillons in (reis)verhalen, memoires en krantenartikelen wijst er op dat het 'oude paradigma' met de focus op muziek en muziekinstrumenten in deze genres nog de boventoon voert. Vanuit die invalshoek ligt het ook voor de hand dat deze geluiden beschreven worden in muzikale termen, dat de 'kwaliteit' van de geluidsbron ter sprake komt en dat ongewenste geluiden gevaarlijk zijn voor iemands muzikaliteit. Deze benadering van geluid brengt Wood er bijvoorbeeld toe om te beweren dat "Hollanders geen muzikaal volk zijn: zij zijn sterk in klokken, maar hunne klokken zelve hebben niet veel te beteekenen" (Wood \& Baarslag, 1878/2002, p. 54). Ook leidt het ertoe dat De Coster wel gedetailleerd schrijft over de klank van stemmen (nasaal, in majeur, in mineur), maar helemaal niets zegt over het geluid van de smederijen op Kattenburg die hij ook bezoekt (Coster \& Janson, ca 1879/1998, pp. 26, 32-33, 36-37). Verder is in deze conceptie van geluid ook de volgende opmerkelijke bewering te plaatsen "Als men ooit zal toestaan, dat kinderen geslagen worden of hun ouders afranselen, zal dit moeten zijn als straf voor schel en wanluidend spreken en zingen." ${ }^{90}$ En tenslotte blijkt zelfs het geluid van karren en rijtuigen een aanslag te vormen op de muzikaliteit "Het is niet te zeggen hoe muziekaal en dus hoe fijn beschaafd de bewoners van groote steden zouden worden,

\footnotetext{
${ }^{90}$ Algemeen Handelsblad, 13-01-1895.
} 
indien ze niet langer het voortdurend geratel, gerammel en gehos in de ooren hebben van karren en rijtuigen." ${ }^{91}$

Op andere plaatsen wordt het geluid van verkeer echter helemaal niet gekoppeld aan (het ontbreken van) muzikaliteit en kwaliteit, maar aan een teveel aan geluid in de stad. Zo verzucht een journalist in 1894 met betrekking tot het eerder genoemde 'trommelen op de Beurs':

Zou de tijd niet zijn aangebroken om die rumoer-makende gewoonte af te schaffen, of liever van dit stadsgedeelte over te brengen naar de kinderspeeltuinen? Wij gelooven dat die gewoonte de jeugd tot leven- en lawaai maken aanzet, en onmogelijk eene uitspanning kan genoemd worden, maar eene geweldproef op het trommelvlies der deelnemers is. Wij bevelen $B$. en $W$. ten zeerste aan de aandacht eens te willen vestigen op het lawaai van 30 juli-4 Aug. a.s. aan dezen hoek der stad, alwaar als centrum van verkeer, de drukte en het geraas toch al oorverdovend zijn (geciteerd uit De Telegraaf in de Leeuwarder Courant, 02-08-1894). ${ }^{92}$

Hier gaat het niet langer om de oorzaak van het geluid, maar om de inwerking op het oor. Het trommelen in het Beursgebouw en het geraas van het verkeer in het centrum van de stad tellen bij elkaar op en zijn samen teveel van het goede. Dit past bij het nieuwe concept van geluid in termen van trillingen die niet vanwege hun kwaliteit maar door hun hoeveelheid "eene geweldproef op het trommelvlies der deelnemers" vormen. Blijft natuurlijk toch de vraag overeind waarom dan toch het 'gedruisch' van bedrijvigheid zo weinig genoemd wordt. Voordat deze vraag verder aan de orde komt, wordt eerst stilgestaan bij de betekenis van en het oordeel over het geluid van de klokken en stemmen die wel frequent genoemd worden.

Zoals eerder werd beschreven dient het luiden van de Amsterdamse torenklokken meestal om expliciete boodschappen te verkondigen, zoals de tijd, brand en ander gevaar, kerkdiensten, begrafenissen, verjaardagen van het koningshuis en andere (feestelijke) gebeurtenissen. Toch komt, afgezien van het aangeven van de tijd, de betekenis van andere boodschappen die via de torenklokken worden verspreid in de teksten nauwelijks aan de orde. Voor Amsterdammers is het klokgelui vooral een vertrouwd geluid. Het volgende fragment over de klokken van Amsterdam komt uit een krantenartikel dat de naturalistische roman Zuster Bertha van Arnold Aletrino (1891) bespreekt.

\footnotetext{
${ }^{91}$ Algemeen Handelsblad, 05-10-1880.

92 Kinderspeelplaatsen uit de negentiende eeuw leken qua uiterlijk, locatie en achterliggend gedachtegoed weinig op de speeltuinen zoals wij die kennen. Ze werden vooral gezien als een middel om kinderen te disciplineren en de betere buurten te vrijwaren van het kattenkwaad van arbeiderskinderen. Het waren omheinde veldjes die meestal op braakliggende terreinen werden aangelegd en daardoor vaak een tijdelijk karakter hadden. In 1880 werd door de industrieel Nicolaas Tettenrode voor de arbeiderskinderen in Amsterdam West de eerste speeltuin in Nederland opgericht (Verstrate, 2012, pp. 166-167).
} 
De taal, de vreemde mode om aan kleuren klanken te geven, hindert soms onze ouderwetsche ooren, maar het talent waarmede geschreven wordt is onmiskenbaar. (...) Elk Amsterdammer heeft, vooral 's nachts in de stilte de klokken zijner stad hooren spelen en slaan en is getroffen door die 'muziek der eeuwigheid.' Ziehier hoe de heer Aletrino zijnen indruk weergeeft: "In de zachte, warme stilte buiten brak plotseling 't carillon der torenklokken hakkelig door de lucht. De Zandtoren begon met zijn helder geluid, lang, met goud-ronde, afgescheiden klanken neêrbrokkelend in het zonlicht, met den afbrommenden naslag van de klok breed galmend over de daken" (Algemeen Handelsblad, 22-11-1891).

De buitenlandse bezoekers, die uiteraard niet of nauwelijks vertrouwd zijn met de expliciete betekenissen van het klokgelui, hebben uiteenlopende meningen over de Amsterdamse klokken. Zij besteden vooral aandacht aan de muzikale kwaliteiten van het geluid en blijken daarin soms sterk beïnvloed door de stemming van het moment.

Een oorverdovend klokgelui, alle uren en alle kwartieren op de maat van een menuet, vervult mijn oren en mijn gedachten met een verschrikkelijk gedreun. (...) Een van de carillons, die de vorige dag zo op mijn zenuwen hebben gewerkt, krijg ik nu weer te horen. In de verte tingelen de maten van een oude gavotte: het is een heel zuivere metaalklank, liefelijk en blij, alsof ergens in de lucht, op een zilveren piano, een feestmuziek getokkeld wordt (Ortigão \& Jong, 1885/1948, pp. 22, 40).

Anders dan tijdgenoten uit Londen, klagen de Amsterdammers maar ook de bezoekers gedurende de periode 1875-1895 weinig over het schreeuwen van venters of over straatmuzikanten. In Londen worden acties tegen straatmuziek vooral gevoerd door schrijvers, kunstenaars, filosofen en vergelijkbare professionals. Zij streven naar maatschappelijke erkenning en voelen zich daarbij gedwarsboomd door het lawaai van straatmuzikanten. Deze verstoren de rust die zij als respectabele professionals verdienen en bovendien nodig hebben voor de uitoefening van hun beroep (Picker, 2000). In Amsterdam is er geen sprake van dergelijke acties noch van tirades waarin nationaliteit of etnische afkomst van deze 'lawaaimakers' een rol speelt, zoals bijvoorbeeld wel te lezen valt in een krantenartikel over 'Street Noises in London' waar gesproken wordt over "bull-throated Germans" en "foreign pests". ${ }^{93}$ Een enkele keer wordt wel aangegeven dat het om Joodse venters gaat ('kinderen Israels') maar nooit is er sprake van

\footnotetext{
${ }^{93}$ Het artikel 'Street Noises in London' is oorspronkelijk gepubliceerd in de London Standard van 24-12-1879 en later in The New York Times van 23-01-1880 (geraadpleegd op 23 maart 2011 op http://query.nytimes.com/mem/archive-free/pdf?res=FA0712FE35551B7A93C1AB178AD85F448884F9.

Ook in 'The Age of Noise : Early Reactions in Vienna, 1870-1914' (Payer, 2007) wordt een vergelijkbare situatie in Wenen beschreven, maar omdat de voorbeelden vaak betrekking hebben op het begin van de $20^{\text {ste }}$ eeuw is een vergelijking met Amsterdam in de periode 1875-1895 niet echt mogelijk.
} 
xenofobische geluiden als in voorgenoemd krantenartikel het geval is en zoals ook Picker beschrijft in zijn boek (Picker, 2000).

Toch was er in Amsterdam, zoals eerder al naar voren is gebracht, sinds jaar en dag een vergunning nodig voor het maken van muziek op straat en het geven van vertoningen. De daaraan verbonden censuurbepaling verdwijnt in 1897 uit de politieverordeningen, maar rond die tijd wordt het maximale aantal vergunningen wel beperkt tot 30. Waarom een limiet wordt ingesteld en hoe deze is bepaald is niet bekend. In haar artikel 'Het beleid van de Amsterdamse overheid ten aanzien van straatmuzikanten 1900-1980', dat in het hoofdstuk over het interbellum opnieuw aan de orde zal komen, oppert Marie van Dijk dat drie factoren een rol kunnen hebben gespeeld. De relatieve toename van de verkeersdrukte, de toename van het geluidsvolume van de draaiorgels en de mogelijkheid dat straatmuziek als een vorm van bedelarij werd gezien die aan banden moest worden gelegd (Dijk, 1981, p. 143).

Desalniettemin zijn er, zoals eerder al is aangegeven, nauwelijks teksten waarin men zich beklaagd over het schreeuwen van straatventers of over muzikanten. Een enkeling klaagt over de slechte kwaliteit van een draaiorgel in de Kalverstraat en verder schrijft men vooral over nachtelijk lawaai in de buurt van uitgaansgelegenheden of over het schreeuwen en zingen van 'het gemeen'.

Zede- of zinlooze liedjes, onbesuisd hossen of zwieren, gillend geschreeuw tot in 't holst van den nacht is 't grootste genot voor 't gemeen, dat dikwerf zijn geld maandenlang heeft opgespaard, om eens ferm kermis te houden, en wanneer de bron uitgeput is, zijn goed achter de schuine deur brengt [de lommerd], om toch maar te kunnen razen en uitspatten (Amsterdammer \& Gouw, 1875/1974, p. 136).

Overigens verschijnen er wel enkele artikelen in Amsterdamse kranten waarin de opkomst van de antilawaai beweging in Londen wordt besproken, echter zonder dat de suggestie wordt gedaan dat er in Amsterdam ook behoefte is aan soortgelijke activiteiten. $^{94}$

Er is te Londen een vereeniging opgericht, tot beperking van straatmuziek en het tegengaan van hinderlijk straatgedruisch. Zij zal een voorstel indienen bij het Parlement, om te verbieden dat straatventers enz. door schreeuwen of eenig ander geraas de aandacht pogen te trekken. Dit voorstel, dat zeker bijval vinden zal, vooral bij hen die veel met hoofdwerk bezig zijn, strekt echter niet om de straatmuziek geheel te weren. Het is alleen een aanvulling van de zoogenoemde Bass's act, die op dit gebied reeds veel goeds heeft gewerkt. De ontwerper van die wet, de Heer Bass, is voorzitter van de nieuwe vereeniging (Het nieuws van den dag: kleine courant, 14-04-1880).

\footnotetext{
${ }^{94}$ Zie ook 'Straatrumoer Londen', Algemeen Handelsblad, 21-2-1895.
} 
Amsterdams gemopper over stemmen en muziek op straat, heeft dus vooral te maken met een verondersteld gebrek aan beschaving bij 'de mindere klasse' als geheel. En zelfs daarover blijken nogal uiteenlopende meningen te bestaan want de inzender van de klachtenbrief over het orgel in de Kalverstraat krijgt van de redactie het advies om te verhuizen en plaats te maken "voor een liefhebber van kattenmuziek. Die moeten er immers ook zijn, al was 't alleen in het belang van schorre orgels en schorre orgeldraaiers" (Het nieuws van den dag: kleine courant, 29-3-1880).

Het Amsterdamse geklaag over het geraas van rijtuigen en karren is meestal verbonden aan de schadelijke invloed van dit geraas op de muzikaliteit of aan de hinder die het oplevert voor hoofdwerkers en voor zieken. Ook spreekt men over 'nodeloos' geraas. Van een koppeling tussen lawaai en zenuwzwakte of -ziekte is er echter in deze teksten nog nauwelijks sprake. ${ }^{95}$ Wat verder opvalt, is de aandacht voor het gevaar dat ontstaat wanneer verkeer niet hoorbaar is. Eerder kwam al aan de orde dat volgens een politieverordening alle voertuigen in tijden van sneeuw bellen dienen te voeren en dat er zorgen geuit werden over het gevaar van te stille paardentram. Blijkbaar functioneert het lawaai dat een rijtuig maakt niet langer als een waarschuwingssignaal dat onder alle omstandigheden voldoet. Dit lijkt er op te wijzen dat het geluidsniveau als geheel toeneemt en zo het geraas van een naderend voertuig overstemt. Die toename van het geluid zal zowel veroorzaakt worden door de grotere verkeersdrukte als door de expanderende bedrijvigheid, zoals ook blijkt uit de volgende klacht over een smidse: "Daar dan bij het slaan der smid (...) het iemand bijna onmogelijk wordt een voertuig te hooren aankomen." ${ }^{\prime 66}$ Het einde van de negentiende eeuw vormt de opmaat naar de voor ons vanzelfsprekende situatie dat alle voertuigen standaard over de mogelijkheid beschikken om een akoestisch waarschuwingssignaal te geven.

Deze ontwikkeling naar een expliciete vorm van signalering bij voertuigen sluit aan bij de tendens naar een meer lokale vorm van berichtgeving via geluid bij brandgevaar. Daar kwam een systeem van elektrische brandmelders, die enkel hoorbaar waren voor de brandweer, in de plaats van het alarm van de nachtwachten dat voordien de hele stad mobiliseerde.

Eigenaardig was vooral de nachtwachtdienst bij brand. Zoo spoedig ergens brand ontdekt was, ging de nachtwacht zijn makkers in de omliggende kwartieren al ratelend en brandschreeuwend waarschuwen. Deze gewaarschuwde nachtwachts deden op hun beurt hetzelfde en zoo wist de stad in een ommezien waar de brand was. Het ongewone spektakel bracht dan gewoonlijk een ontzaggelijke massa menschen op de been en daar torenwachters bovendien brandende lantaarns uit-

\footnotetext{
${ }^{95}$ Hoewel neurasthenie als diagnose (in Londen) vanaf 1885 in gebruik was, blijkt dat deze diagnose vooral in de eerste drie decennia van de twintigste eeuw te worden gebruikt. Anders dan vaak wordt verondersteld is het een ziektebeeld dat ook bij de lagere klassen en ook bij mannen werd gediagnosticeerd (Taylor, 2001).

${ }^{96}$ Archief Secretarie Publieke Werken Amsterdam, inventarisnummer 1587 (jaar 1876) zaaknummer 1324.
} 
hingen in de richting waar de brand was, kon iedereen zien welke richting hij uit moest om ook het schouwspel te kunnen gadeslaan (Batelt, 1912, p. 50).

In het artikel 'Sounds of the city: the soundscape of early modern European towns' (Garrioch, 2003) beweert de auteur dat het auditieve semiotisch systeem dat het dagelijks leven in (vroeg) moderne Europese steden structureerde, geleidelijk aan betekenis verliest. Hoewel het hier maar om een beperkt aantal voorbeelden uit Amsterdam gaat, lijkt er inderdaad een ontwikkeling gaande van communicatie (onder andere via torenklokken en ratels) op het niveau van de hele stad naar een meer lokale en/of meer toegespitste vorm van signalering. Dit geldt uiteraard enkel voor informatie die expliciet via geluid wordt gecommuniceerd en niet voor de alle onopzettelijke geluiden die ook allerlei betekenissen overbrengen. Voor insiders blijven deze geluiden vol betekenis. Denk bijvoorbeeld aan het eerder genoemde geluid van "het eigenaardig ratelen, dat elk koetsje eigen was" en grachtenbewoners niet alleen vertelde om welke familie het ging maar ook of deze op weg was naar het station of visites ging afleggen (Kluytenaar, 1936, p. 252).

\section{Conclusie}

Aan het einde van de negentiende eeuw doen zich in Amsterdam allerlei veranderingen voor die in principe gevolgen kunnen hebben voor het geluid dat de stedeling dagelijks omringt. Bloeiende handelsactiviteiten en daarbij behorende diensten zorgen voor meer kantoren, winkels, horeca en toeleveringsbedrijven in de binnenstad en verdrijven het wonen geleidelijk uit de grachtengordel. Het openbaar vervoer in de vorm van door paarden getrokken omnibussen en trams doet zijn intrede. Opkomende industrialisatie leidt tot bedrijven van grotere omvang, stoommachines als krachtbron en een fors groeiende populatie van doorgaans ongeschoolde arbeiders.

Met de groeiende bedrijvigheid neemt ook het aantal bewegingen van goederen en personen in de stad toe, hoewel het grootste deel van de bevolking nog steeds te voet gaat. Handkarren, paard en wagen en venters vormen een vast onderdeel van het straatbeeld, net als ambachtelijke en huishoudelijke activiteiten op locaties waar woningen zijn. De keienbestrating wordt heel geleidelijk vervangen door asfalt, de nachtwacht verdwijnt, de boomklok verliest haar functie en met de invoering van een nieuw systeem van brandmelding neemt ook het belang van de torenklokken als stedelijk communicatiemiddel af.

Voor velen zijn de woon- en leefomstandigheden erbarmelijk. Men woont opeengepakt en van een scheiding van woon- en werkgebieden is nauwelijks sprake. Soms wordt in een eenkamerwoning zelfs nog een beroep uitgeoefend en de groei van het aantal Hinderwetvergunningen voor bedrijven die veel geluid produceren - drukkerij- 
en, smederijen, koperslagers - doet vermoeden dat de kans op geluidsoverlast zelden een reden is om een vergunning te weigeren of in te trekken.

In teksten over het stadsleven is er relatief veel aandacht voor het geluid van stemmen, klokken en carillons. Naast opmerkingen over het verwerpelijke gezang en gedrag van 'het gemeen', zijn er af en toe klachten over het 'geraas' en 'gedruisch' van het verkeer en over voertuigen en karren die men niet hoort aankomen. Dit laatste kan het gevolg zijn van asfaltering van de straat of van een maskering van het geluid van naderende voertuigen door een toename in aantal en volume van andere bronnen van geluid.

In het onderzoek naar geluid als verschijnsel gaan het oor en het horen een grote rol spelen ten koste van de aandacht voor de stem en muziekinstrumenten. Het denken over geluid in termen van muziek en niet-muziek maakt geleidelijk plaats voor geluid als trilling. In de wetenschap wordt muziek daardoor niet langer als het ideaaltype van geluid gezien, maar als een subcategorie. De sporen van de vroegere verklaringen voor het fenomeen geluid zijn echter nog volop aanwezig in het dagelijkse taalgebruik en dus ook in populaire ideeën en opvattingen. In beschrijvingen van stadsgeluid wordt dan ook nog veel gebruik gemaakt van muziektermen en van vergelijkingen en metaforen die verband houden met muziek en muziekinstrumenten. In die context is het ook begrijpelijk dat er nog zoveel aandacht uitgaat naar de stemmen en klokken die vroeger golden als de ideale en dus meest belangrijke bronnen van geluid.

Tegen de achtergrond van de vermoedelijke toename van het geluid in de stad, blijft het echter opmerkelijk dat het lawaai van rijtuigen zo uitvoerig aan bod komt en dat van machines en bedrijvigheid zo weinig. Een oorzaak zou kunnen zijn dat het geratel van de rijtuigen over keien een oud en vertrouwd en bovendien moeilijk te negeren geluid is dat in de loop der tijd gecanoniseerd is als een typisch stadsgeluid, terwijl het geluid van intensieve nijverheid daarvoor in Amsterdam nog te nieuw is. Maar dat zal niet de enige reden zijn. Om te beginnen behoren degenen die het meest geconfronteerd worden met lawaai producerende bedrijven en machines tot de $95 \%$ die geen stem hebben en bovendien heel andere zorgen op het gebied van voeding en huisvesting. Bovendien ligt het niet voor de hand om in tijden van economische malaise te gaan klagen over het geluid van activiteiten die kunnen zorgen voor brood op de plank (Bijsterveld, 2008, p. 63). Getuige het volgende citaat is het dan ook niet vreemd dat een vergunning wordt geweigerd op grond van het verwachte 'onzedelijk' zingen en gedrag op straat en niet vanwege het lawaai van de stoommachine.

B. en W. van Nieuwer-Amstel deelden blijkbaar die mening [dat diamantbewerkers een onhandelbaar volkje zijn]; althans in 1888 weigerden zij een vergunning voor het oprichten van een stoomslijperij aan het Tuinpad af te geven omdat de hoofdonderwijzer van een naburige school daartegen als volgt bezwaar had gemaakt: 'Het personeel der diamantslijperij laat, wat zedelijk gehalte betreft, wel wat te 
wenschen over. Zoo de oprichting geschiedt, zullen de slijpers met stenen gooien, straatliedjes zingen en allerlei baldadigheden uitvoeren (Tijn, 1974b, pp. 67-68). 



\section{"Met schor gehoest van nijdige claxons": Stadsgeluid in het interbellum}

\section{Inleiding}

Auto's ruischen met schor gehoest van nijdige claxons over den glim-natten rijweg, haastig door hun vrijgetoeterde bedding, trams bonkeren bel tinkelend over veelkleurig glinsterende rails, archaïstische aapjes hobbelen traag en belachelijk door het moderne snelverkeer, kopwippend de armelijke paardjes met hun stijve pooten en hun touwrafeligen staart (Jong, ca. 1920, pp. 5-6).

De 'aapjes' in dit citaat zijn de blinkend gepoetste koetsjes met koetsiers in "donkerblauwe kleedij, zwarten hoed en kokarde" van de Amsterdamsche Rijtuig Maatschappij (A.R.M.). ${ }^{97}$ Ze deden in 1881 hun intrede in Amsterdam, als antwoord op de sterk groeiende behoefte aan personenvervoer. Hoewel tijdgenoten vinden dat ze er eigenlijk niet meer thuishoren - ze zijn immers "archaisch" en "hobbelen traag en belachelijk door het moderne snelverkeer" - maken ze in 1920 nog steeds onderdeel uit van het straatbeeld. De aapjes zullen ook de zogenaamde "atax" overleven, de elektrisch aangedreven taxi's waarmee de A.R.M. in 1906 de primeur had voor Nederland. ${ }^{98}$ Bovendien zorgt gebrek aan benzine tijdens de Tweede Wereldoorlog voor een opvallende terugkeer van paard en wagen op straat. Maar verder is de opmars van de benzinewagen na de Eerste Wereldoorlog in Nederland niet meer te stuiten. Niet langer vormen kleppende hoeven en ratelende karren de hartenklop van het stadsverkeer, maar het 'schor gehoest' van de claxon en het suizen van rubber over asfalt.

Daarmee is niet gezegd dat er in het interbellum geen ander verkeer op straat is. Integendeel, behalve auto, tram, paard en wagen zijn er ook nog talloze handkarren, voetgangers en vooral veel fietsers. Al die verschillende verkeersdeelnemers moeten nog aan elkaar wennen en dat leidt onder meer tot een kakofonie van claxons en hoorns. Tot ver in de jaren dertig zijn autobestuurders geneigd en/of gedwongen om zichzelf al toeterend vrije doorgang te banen. In dit hoofdstuk over het geluid van Amsterdam gedurende het interbellum, zal dit getoeter uitgebreid aan bod komen. Het is een geluid dat ook in die tijd veel aandacht krijgt en meestal bestempeld wordt

\footnotetext{
97 'Bij het gouden Jubileum der A.R.M.: De traditie van Aapje en Atax', De Tijd, 13-09-1931, Persdocumentatie Collectie Stadsarchief Amsterdam' (toegangsnummer 30486, deel onderwerp rijtuigverkeer (194), blad 86469).

98 "Die eerste 'atax'-en hadden niet veel van moderne auto's; veel meer geleken zij op coupétjes zonder paard. De bestuurder - men sprak nog van koetsier - zat, onbeschut voor weer en wind, hoog op den bok" (Algemeen Handelsblad, 11-09-1931). Zie ook (Mom, 1997).
} 
als ongewenst, met andere woorden als 'lawaai'. Het getoeter is dan ook een centraal thema in de antilawaai beweging die in Nederland vooral in de vroege jaren dertig gehoor vindt.

Evenals in het voorgaande hoofdstuk over het einde van de negentiende eeuw en het volgende over de oorlogsperiode, wordt in dit hoofdstuk over het interbellum het geluid van Amsterdam geanalyseerd vanuit de perspectieven van de 'ecologie', de 'semiotiek' en de 'politiek' van geluid. Op die manier komen we meer te weten over karakteristieke aspecten van het stadsgeluid in deze tijd, de aandacht die tijdgenoten er aan schenken, de betekenis die ze er aan toekennen en het oordeel dat ze erover vellen. Omdat de toenemende belangstelling voor de antilawaai beweging er op wijst dat het geluid van de stad explicieter dan voorheen onderwerp wordt van discussie, krijgt de analyse vanuit het perspectief van de 'politiek' van geluid in dit hoofdstuk extra nadruk. Daarbij gaat het onder andere om de vraag welke specifieke historische en lokale factoren er toe bijdragen dat in Amsterdam bepaalde geluiden worden aangewezen als lawaai of ongewenst geluid, terwijl andere ogenschijnlijk vergelijkbare klanken genegeerd worden in discussies over het dagelijks leven in de stad.

De opkomst van de antilawaai beweging in Nederland sluit aan bij soortgelijke ontwikkelingen in Europa en Amerika. In de Verenigde Staten, Engeland en Duitsland is er zelfs sprake van een heropleving van activiteiten uit het eerst decennium van de twintigste eeuw, maar nu in de jaren twintig en dertig zijn de grote antilawaai campagnes vooral gericht op het verkeer in de stad (Bijsterveld, 2008, pp. 93-124). Desondanks komt de vraag op of al deze situaties wel vergelijkbaar zijn. In het vorige hoofdstuk hebben we gezien dat Amsterdam zich veel later en ook langzamer ontwikkelde dan andere Europese hoofdsteden. ${ }^{99}$ Bovendien is Amsterdam qua straten- en grachtenpatroon, breedte van straten, hoogte van bebouwing en transportmiddelen (denk aan de vele fietsen) niet te vergelijken met Londen, Berlijn, Parijs of New York. Het kan dus niet anders dan dat veranderingen in verkeersmiddelen en de intensiteit van het verkeer zich in een voor Amsterdam specifiek tempo en met even specifieke veranderingen in klank voltrekken.

Dit wil niet zeggen dat die internationale ontwikkelingen geen invloed hebben op de situatie in Amsterdam. Integendeel, ze vormen de achtergrond waartegen eigen ervaringen van en opvattingen over de stad worden afgezet en vorm krijgen. Zowel de situatie in Duitse en Amerikaanse steden als de opvattingen over het stedelijk leven dat daar tot ontwikkeling komt, zijn gedurende het interbellum belangrijke inspiratiebronnen voor Nederland. In de eerste plaats is Nederland sinds de negentiende eeuw niet alleen in economisch opzicht, maar ook via literatuur, muziek, filosofie, weten-

\footnotetext{
${ }^{99}$ In de eerst helft van de negentiende eeuw groeide de bevolking van Amsterdam met 2\%, van Boedapest met 189\%, Brussel 280\%, Londen 140\%, Parijs 93\% en Rome 7\%. Van 1850 tot 1900 liet Amsterdam een groeipercentage zien van 128\%, Boedapest 370\%, Brussel 139\% Londen 68\%, Parijs $150 \%$ en Rome $166 \%$. In 1850 telde Amsterdam 224.000 inwoners en vijftig jaar later 510.850 (Hall, 1986, p. 247 geciteerd in; Wagenaar, 1998, p. 23).
} 
schap en het universitaire systeem van de Bildung verbonden met Duitsland. Daarbij is vooral sprake van een stroming van 'cultuurgoederen' van Duitsland naar Nederland, al komt daar in de loop van het interbellum enige verandering in (Boterman, 2003, pp. 13-14). Verder blijkt uit publicaties over de Nederlandse dagbladen aan het begin van de twintigste eeuw dat men na 1918 meer dan voorheen de blik richt op ontwikkelingen in Amerika. Dit komt niet alleen tot uiting in veranderingen in de opbouw van de dagbladen en de wijze van berichtgeving, maar ook in een toenemende interesse voor het moderne leven in de Nieuwe Wereld (Broersma, 2010, p. 175; Wolf, 2007, p. 93).

De beleving van het Amsterdamse klanklandschap en de veranderingen die zich daarin gedurende het interbellum voordoen is dus enerzijds gebonden aan lokale fysieke, sociale, economische en culturele factoren. Anderzijds wordt die beleving door de groeiende verspreiding van de dagbladen onder de bevolking en door de nieuwe oriëntatie van de berichtgeving in die kranten, veel sterker dan voordien het geval was beïnvloed door ideeën en opvattingen over het moderne leven in 'toonaangevende' wereldsteden als Berlijn en New York. Om zicht te krijgen op de resultaten van die wisselwerking en deze te verklaren, staan we eerst stil bij de bronnen van geluid die karakteristiek zijn voor het Amsterdamse klanklandschap in deze periode. Daarbij wordt hier en daar al ingegaan op de betekenis van die specifieke geluiden voor tijdgenoten en op verbanden met discussies over het leven in de stad. Vervolgens ligt in het laatste deel van dit hoofdstuk de nadruk op de analyse van de Amsterdamse soundscape vanuit het perspectief van de 'politiek van geluid'.

Bij deze laatste analyse wordt gebruikt gemaakt van een theoretisch raamwerk dat ontleend is aan een constructivistische visie op sociale problemen. In die visie wordt een 'sociaal probleem' gekenmerkt door het feit dat er een groep van personen is die een bepaalde situatie als problematisch aanwijst. Dit betekent onder meer dat er geen sprake is van een 'sociaal probleem' zolang een situatie door delen van de samenleving niet als zodanig wordt aangemerkt, hoe hinderlijk deze situatie ook mag zijn voor de individuen die ermee geconfronteerd worden (Loseke, 1999, pp. 13-14). Omgekeerd zorgt het definiëren van een situatie als problematisch er voor dat er een 'sociaal probleem' is, los van het feit of er 'objectieve' omstandigheden zijn die aantonen dat individuen onder die situatie lijden of er nadeel van ondervinden. Dit betekent in principe dat een geluid door een gemeenschap op een bepaald moment als lawaai kan worden aangemerkt, zonder dat er op welke manier dan ook, in termen van bronnen, volume of aard van de klank, sprake is van een toename of verandering van dat geluid. In dat geval staat het geluid symbool voor een situatie die vanwege andere en wellicht minder bespreekbare motieven omstreden is.

Verder is het van belang om te weten dat er bij het aanwijzen van situaties als sociaal probleem, vaak (bewust of onbewust) wordt uitgegaan van de veronderstelling dat het probleem door mensen wordt veroorzaakt, door mensen kan worden opgelost en bovendien dat er ook daadwerkelijk iets gebeuren moet. Naast de groep die het probleem benoemt, is er dan ook altijd een groep die wordt gezien als de veroorzakers 
van het probleem en een groep die het probleem moet oplossen (Loseke, 1999, pp. 321). De laatste twee groepen hoeven niet dezelfde te zijn. Buurtbewoners kunnen bijvoorbeeld dag en nacht zorgen voor overlast van radiogeluid, terwijl de oplossing wordt gezocht in het door de overheid laten reguleren van de tijdstippen waarop radiozenders mogen uitzenden.

De analyse van het Amsterdamse klanklandschap vanuit het perspectief van de politiek van geluid en met behulp van het voorgaande raamwerk leidt tot de volgende vragen: Welke geluiden komen wel en welke niet aan bod in de discussies? Welke worden als lawaai bestempeld en welke niet? Wie voert deze discussies over geluid en wiens stem is opvallend afwezig? Wie wordt aangewezen als slachtoffer en wie als veroorzaker van het ongewenste geluid? Welke interventies worden voorgesteld en waarom? En tenslotte, wat zijn de factoren die er voor zorgen dat geluid in de loop van het interbellum in Amsterdam een grotere rol gaat spelen in discussies over het dagelijks leven in de stad?

\section{Geluid en tekst uit het begin van de twintigste eeuw}

Het publieke debat over het geluid en lawaai van Amsterdam wordt in dit hoofdstuk beluisterd aan de hand van artikelen en ingezonden brieven in kranten, een beperkt aantal boeken over de eigen ervaringen in Amsterdam en de verslagen van de incidentele discussies over geluid en lawaai in de Amsterdamse gemeenteraad. ${ }^{100}$ Net zoals dat het geval was voor de casus 1875-1895, is het merendeel van de artikelen die voor de analyse zijn gebruikt afkomstig uit het Algemeen Handelsblad. Verder is gebruik gemaakt van De Groene Amsterdammer, De Telegraaf, Het Vaderland en de Leeuwarder Courant. ${ }^{101}$

\footnotetext{
100 Ook in dit hoofdstuk zijn publicaties die later zijn geschreven dan de periode waarop ze betrekking hebben enkel gebruikt voor de inventarisatie van de geluiden die men mogelijk gehoord zou kunnen hebben (ecologie van geluid). Ze zijn buiten beschouwing gebleven bij de analyse van het discours over geluid in het interbellum. Het gaat in dit geval om herinneringen aan (Joods) Amsterdam vóór het uitbreken van de Tweede Wereldoorlog (Bloemgarten, 2003; Bregstein \& Bloemgarten, 2004; Presser, 1974; Sluyser \& Drees, 1957).

${ }^{101}$ Alle artikelen van De Telegraaf, 11 artikelen van het Algemeen Handelsblad en 1 artikel uit De Groene Amsterdammer zijn afkomstig van de 'Persdocumentatie' (toegangsnummer 30486) en/of het 'Archief van de Politie' (toegangsnummer 5225) van Stadsarchief Amsterdam. De overige artikelen afkomstig uit de jaargangen 1918 tot en met 1939 maken onderdeel uit van de databank Historische Kranten of het online archief van De Groene Amsterdammer (http://www.groene.nl/historisch/1877). De artikelen zijn geselecteerd uit een totaal van ongeveer 1600 artikelen waarin een (combinatie) van de volgende woorden en tekenreeksen minimaal één keer voorkomt: 'Amsterdam', 'burengerucht', 'electromotor', 'gedruis', 'gedruis*', 'gedruisch', 'geluid', 'geluid van', 'geraas', 'gesuis', 'grammofoon', 'herrie', 'hinder', 'lawaai', 'luidruchtig', 'radio', 'rumoer', 'rumoerbestrijding', 'rust', 'stad', 'in de stad', 'stadsgedruis', 'stadslawaai', 'stadsrumoer', 'stilte', 'meer stilte', 'straatkabaal', 'straatlawaai', 'straatrumoer', 'verkeer', 'verkeerslawaai', 'vliegtuig'.
} 
Alvorens in te gaan op het geluid van Amsterdam en de discussies die daarover tijdens het interbellum worden gevoerd, is het van belang om stil te staan bij drie punten waarop de voorgenoemde teksten verschillen ten opzichte van die uit het eind van de negentiende eeuw. Deze verschillen hebben betrekking op de manier waarop tegen het fenomeen 'geluid' wordt aangekeken, op de maatschappelijke positie van de woordvoerders en op de mate waarin de eigen beleving beïnvloed wordt door ideeën en opvattingen over het moderne leven in wereldsteden.

Het laatste punt is eerder in dit hoofdstuk toegelicht en wat het concept 'geluid' betreft hebben we in het vorige hoofdstuk gezien dat er aan het eind van de negentiende eeuw grote veranderingen doorbreken in het denken over geluid die samenhangen met nieuwe toepassingen zoals de telefoon en de fonograaf. Ondanks die doorbraken waren de sporen van het oudere concept, waarbij geluid beschouwd wordt als hetzij 'muziek' hetzij 'niet-muziek' en waar het zijn kwaliteit primair ontleent aan de geluidsbron, zeker nog aanwijsbaar in het gedachtengoed van leken. Denk maar aan het citaat waarin met verbazing wordt geconstateerd dat het blaffen van een hond net zo goed wordt vastgelegd door de fonograaf als het gezang van een operaster. Hoewel dit concept van geluid ook in de twintigste eeuw nog niet helemaal verdwenen is, ligt nu bij het denken over geluid de nadruk op het horen en op de effecten van geluid op de mens.

Dat het lawaai door de bewoners der groote steden verafschuwd wordt niet alleen omdat het onaangename gewaarwordingen wekt, doch ook omdat het werkelijk een sloopenden invloed uitoefent op het zenuwgestel en op de arbeidsprestatie, is door tal van experimenten bevestigd (Dubois, 1932).

We zullen deze aandacht voor de inwerking van geluid op de mens en vooral op 'de zenuwen' in dit hoofdstuk geregeld tegenkomen in de tekstfragmenten. Verder vindt de aandacht voor de gevoeligheid van het menselijke oor haar neerslag in de meetmethoden en meeteenheden voor geluid die in het interbellum worden ontwikkeld en onder andere worden toegepast voor het meten van het geluid in steden. In een enkel geval worden deze metingen ook al genoemd in krantenberichten uit Amsterdam en om die reden worden ze hier kort toegelicht.

Omdat het bij geluidsgolven om minuscule hoeveelheden energie gaat wordt het meten van de intensiteit van geluid pas mogelijk nadat ontwikkelingen in de telefoontechnologie het splitsen van een complex geluid naar frequenties mogelijk maken en de energie van het geluid van dergelijke frequenties met behulp van radiobuizen kan worden versterkt (Bijsterveld, 2008, p. 105). Het ter beschikking komen van deze mogelijkheid om te meten leidt vervolgens in het interbellum tot de ontwikkeling van diverse meeteenheden voor de intensiteit van geluid. Naast de ons bekende "decibel" 
zijn dat de "phon", de "sone" en de "wien". ${ }^{102}$ Wat al deze meeteenheden met elkaar gemeen hebben is dat ze op een of andere manier gerelateerd zijn aan de gevoeligheid van het menselijk oor. Ze verbinden de intensiteit van de (fysieke) geluidsgolf met een menselijk oordeel over de luidheid van een geluid. Tot zover past deze ontwikkeling volledig bij de tendens om het onderzoek naar geluid te richten op het oor en het horen en niet meer uitsluitend op de geluidsbron en haar karakteristieken.

Paradoxaal is echter dat er uiteindelijk bij het meten van geluid in steden een apparaat ontwikkeld wordt, een zogenaamde objectieve lawaaimeter, dat zonder directe tussenkomst van het menselijk oor de luidheid of het volume van een geluid aangeeft in decibel. Het paradoxale zit in het feit dat de uitkomst van dergelijke metingen niet altijd strookt met het menselijk oordeel. Dit wordt gedeeltelijk veroorzaakt doordat het oor in staat is om meer nuances van geluiden waar te nemen dan de geluidsmeters kunnen meten (Bijsterveld, 2008, pp. 109-110). Zo kan het voorkomen dat geluid dat volgens toehoorders luider is, volgens de lawaaimeter minder decibel produceert. ${ }^{103}$ We zien daar later nog een specifiek voorbeeld van. Hier wil ik vooral de aandacht vestigen op het feit dat voor het menselijk oordeel over de luidheid en de eventueel daaraan verbonden ongewenstheid van een geluid, de geluidsbron en andere omstandigheden ook een rol spelen. Om die reden zijn de geluidsmeters ook in Amsterdam vanaf hun introductie in 1937 omstreden (Bijsterveld, 2008, pp. 174-180). Dat heeft, zoals we later zullen zien, ook gevolgen voor de discussies over het stadsgeluid.

Het laatste verschil tussen de teksten uit het interbellum en het eind van de negentiende eeuw heeft betrekking op de maatschappelijke positie van de stemmen die we 'horen'. Bezoekers uit het buitenland komen in het interbellum minder aan het woord, maar Amsterdammers des te meer. Journalisten, auteurs en sprekers in raadsvergaderingen behoren op zijn minst tot de Amsterdamse middenklasse en zijn meestal van het mannelijk geslacht. Bovendien bevinden zich onder de schrijvers van brieven aan de krant nu ook vrouwen uit de top en de middenklasse, en geschoolde arbeiders.

\section{De ingrediënten van het klanklandschap tijdens het interbellum}

Als we willen begrijpen wat de geluiden van de stad tijdens het interbellum voor Amsterdammers betekenen en hoe zij er over oordelen, zullen we ook moeten weten wat de belangrijkste geluidsbronnen zijn en welke eventuele veranderingen zich daarin

\footnotetext{
${ }^{102}$ Voor een overzicht van de totstandkoming van deze eenheden, de onderlinge verschillen en de reden waarom de decibel uiteindelijk het meest gebruikt wordt zie (Bijsterveld, 2008, pp. 104-110).

${ }^{103}$ De gevoeligheid van het menselijk oor voor geluidssterkte is niet voor alle geluidsfrequenties gelijk. Om deze reden werden in de loop van jaren dertig lawaai- of geluidsniveaumeters ontwikkeld die zijn afgestemd op de hogere $(A)$ of de lagere $(B)$ frequentie gebieden en metingen uitdrukken in $d B(A)$ of $d B(B)$ (Bijsterveld, 2008, p. 109).
} 
gedurende deze periode voordoen. In 1938 beschrijft Timmerman het geluid van Amsterdam aan het einde van de voorgaande eeuw en vergelijkt dat met zijn eigen tijd: "Denken wij ons het auto-getoeter, het gemaal van muziekschijven, het jengelen van luidsprekers, indien mogelijk, een oogenblik weg, dan was het veel rumoeriger in de stad tóén dan nu. Géén asfalt, géén gummibanden, géén verbod van luidkeels venten, géén geheelonthouding, zelfs niet half, géén vaste dagen voor draaiorgels of andere muziekanten" (Timmerman, 1938, p. 257). De auteur laat er geen twijfel over bestaan dat hij de nieuwe geluiden, het getoeter, gemaal en gejengel, niet kan waarderen, maar naar zijn oordeel is er nu in Amsterdam niet méér geluid dan voorheen. Andere materialen en nieuwe regels zorgen voor minder 'rumoer'. Dat wordt ook begin jaren dertig in Groningen en Den Haag opgemerkt door inwoners die suggereren dat het in Amsterdam stiller is dan in hun eigen stad. Daar ratelen nog geregeld karren zonder gummibanden over de keienbestrating of is het nog de gewoonte om de carillons 's nachts te laten spelen. ${ }^{104,105,106}$

\section{Geluid van verkeer}

Met het grootscheeps aanpakken van de asfaltering in de jaren twintig loopt Amsterdam vóór op andere Nederlandse steden (Buiter, 2005, pp. 145, 176). Het geratel van wagenwielen over keien, 'rateldonderen' noemt Timmerman het, dat over een lengte van maar liefst tweehonderd meter door de straten resoneert, verdwijnt daardoor straat voor straat uit de stad. Aan het begin van dit hoofdstuk hebben we gelezen dat

\footnotetext{
${ }^{104}$ Het Vaderland 18-09-1930, 06-09-1932 en 10-03-1937; Klachtenbrieven Groningen 1936, nummers 9 en 66.

${ }^{105}$ Ben Sajet kijkt in 1977 terug naar het eind van de negentiende eeuw toen hij als kind aan het Waterlooplein woonde. Anders dan Timmerman is hij van mening dat het destijds veel stiller was in de stad. "De rust, de stilte om je heen viel natuurlijk in die tijd niet zo erg op, het was eigenlijk vanzelfsprekend. Maar tegenwoordig valt het me wel op als ik in de Van Baerlestraat kom met al die auto's die daar razen en altijd dat geluid om je heen dat vind ik afschuwelijk. Als ik dan denk aan die zondagen die we gehad hebben toen er geen auto's reden, dat was toch een verademing!" (Sajet \& Fels, 1977, pp. 12-13).

Herinneringen aan het geluid van andere plaatsen en vroegere tijden zullen doorgaans sterk gekleurd worden door de situatie op het moment dat de herinnering wordt verwoord. Zowel Timmermans en Sajets vergelijking van twee tijdsgewrichten, als de geconstateerde verschillen tussen het geluid van enerzijds Amsterdam en anderzijds Groningen en Den Haag in 1930, moeten om die reden met enige voorzichtigheid worden geïnterpreteerd. Toch hecht ik meer waarde aan de herinneringen uit de jaren dertig, dan aan de memoires van Ben Sajet uit de jaren zeventig. In de eerste plaats omdat Sajet terug kijkt naar een tijd die dan al veel langer in het verleden ligt, maar ook omdat de observaties van Timmerman en zijn tijdgenoten elkaar aanvullen.

${ }^{106}$ Amsterdam loopt echter niet in alles voorop. Bij de moeizame behandeling in de gemeenteraad van een wijziging van de Politieverordening ter voorkoming van hinder van radio's etc. in 1930, wordt diverse malen opgemerkt dat soortgelijke regelgeving in Den Haag en elders in Nederland al langer van toepassing is en daar goed functioneert (Stadsarchief Amsterdam, Gemeenteblad 1930, Tweede Afdeeling, 23 Oct. 1930, pp. 1986-2013).
} 
auto's in 1920 al over het Rembrandtplein ruisen, maar zes jaar later boldert het verkeer aan de voet van de Westertoren nog steeds over de keien.

Elf uur's morgens. De lucht is van een kil, strak, donkerblauw; een onpeilbare, onbewogen zee, waarin de vlokkige, donkere en lichte wolken-eilanden snel voortdrijven. Tegen die lucht verheft zich, scherp omlijnd, het slanke silhouet van den Westertoren. (...) Aan den voet davert het straatrumoer. Karren ratelen; vrachtauto's bolderen over de hobbelkeien; een tram maakt, met krassend en gierend geluid, de bocht van de Raadhuisstraat. (...) Achter den toren ligt een rustiger stuk Westermarkt, afgezonderd van het verkeersrumoer. Verwijderd klinkt het gerucht der voertuigen, hier nu overstemd door het fluiten en bassen van een draaiorgel. Een fox-trott mengt zich in het geroezemoes.... (Algemeen Handelsblad, 22-041926).

Naast de geleidelijke asfaltering van de stad zorgt ook de motorisering voor steeds minder karrengeratel. Volgens cijfers uit 1930 zijn er in dat jaar 2350 karren met 'paardentractie' in de stad, vijftig minder dan het voorgaande jaar. In 1930 worden er tevens 3361 vrachtwagens geteld, meer dan zes keer het aantal van 500 in 1921. Op basis van deze cijfers lijkt het aannemelijk dat het gemotoriseerde vrachtvervoer niet enkel in de plaats komt van paard en wagen, maar dat het vrachtvervoer ook toeneemt. Het personenvervoer per rijtuig en per auto maakt een soortgelijke ontwikkeling door, zij het iets minder spectaculair. In 1930 zijn er 2475 rijtuigen in de stad en 6300 personenauto's. Het aantal personenauto's is daarmee sinds 1921, toen er 1800 werden geteld, meer dan verdrievoudigd. ${ }^{107}$

Tegenover het geleidelijk verdwijnen van de ratelende wielen staat dus een meer dan evenredige groei van motorgeluid en autogetoeter. Maar het ene geluid is het andere niet en in de beleving gaat het natuurlijk niet om een simpele optelsom. Bovendien kan, zoals eerder al is besproken, de waarneming door mensen afwijken van de uitkomsten die een meetapparaat geeft. En dat gold zeker voor de eerste generatie van meetinstrumenten, die bovendien moeite hadden om snel wisselende geluiden nauwkeurig te meten (Bijsterveld, 2003, p. 184). Een mooi voorbeeld is de meting van het geluid in de straten van New York door Edward Elway Free, wetenschapsredacteur voor het tijdschrift Forum, in 1926. Hij moet tot zijn verbazing concluderen dat paard en wagen veel meer geluid produceren dan auto's en vrachtwagens. Dat men desondanks vindt dat het stadsgeluid toeneemt, wordt geweten aan de toename van het verkeer of aan het feit dat niet zozeer het volume van het geluid een probleem is maar het soort geluid. Verrassend is ook dat men vóór de meting van oordeel is dat de

\footnotetext{
${ }^{107}$ In 1930 zijn er 25 rijtuigen minder in de stad dan in het voorafgaande jaar. Dit cijfermateriaal is afkomstig van: (Rodrigues de Miranda, 1921, pp. 78-79; Rooy, 2007, p. 591); Algemeen Handelsblad, 12-03-1930, 2803-1930 en 27-08-1930; De Telegraaf, 27-02-1930.
} 
luchtspoorwegen de meeste herrie veroorzaken, terwijl de meting uitwijst dat op straatniveau het geluid van personenauto's en vrachtverkeer groter is ( $E$. Thompson, 2002, pp. 148-149).

Maar ook een toename van het verkeer hoeft niet per definitie voor meer geluid te zorgen. In diverse artikelen over het geluid in de Amsterdamse straten wordt zelfs het omgekeerde beweerd. "Meestal zelfs is het totaal van geluiden bij groote drukte minder, omdat de bestuurders dan meer den stroom volgen en alles in file rijdt. Fileverkeer is dus bevorderlijk voor de rust." ${ }^{108}$ Oordelen over meer of minder geluid en de verklaringen die daarvoor worden gegeven, moeten dus ook als ze afkomstig zijn van tijdgenoten, met voorzichtigheid worden geïnterpreteerd.

De economische ontwikkeling en de groei van de bevolking lopen aan het eind van de negentiende eeuw en tijdens het interbellum in Amsterdam niet veel uiteen. De trends in handel, scheepvaart, financiële dienstverlening en nijverheid die sinds 1870 tot ontwikkeling komen, zetten in ieder geval door tot de economische crisis in de jaren dertig (Wagenaar, 1981). Volgens Geert Mak is Amsterdam zelfs tot in de jaren vijftig de belangrijkste industriestad van Nederland echter zonder een allesoverheersende bedrijfstak. "Een industrie van talloze kleintjes" (Mak, 2007, p. 300). Wel is het zo dat de industrialisering en daarmee gepaard gaande economische groei pas in de jaren twintig van de twintigste eeuw leidt tot een 'sociale revolutie', in de zin van het in versneld tempo kleiner worden van de materiële ongelijkheid tussen bevolkingsgroepen in de stad (Meere, 1979, p. 33).

De bevolking groeit van iets minder dan een kwart miljoen in 1850, naar een half miljoen in 1900, driekwart miljoen in 1930, en om en nabij 800.000 inwoners in 1940 (Buiter, 2005, p. 152). Met de annexatie van omliggende gemeenten in 1921 komen er in één klap 35.000 Amsterdammers bij terwijl het grondgebied verviervoudigt. Amsterdam heeft dat extra grondgebied hard nodig. Aan het eind van de negentiende eeuw barstte de oude stad al uit haar voegen. Sanering van krotten in de Jodenbuurt, de Kadijken en de Jordaan is dringend noodzakelijk; de bevolking blijft groeien en bovendien verdrijft de behoefte aan kantoren, hotels en warenhuizen tot ver in de twintigste eeuw het wonen uit de binnenstad. Gedurende het interbellum zal dan ook in, maar vooral rondom, de oude stad voortdurend worden gebouwd (Mak, 2007, pp. 300-306; Rooy, 2007a; Wagenaar, 1981).

Een belangrijke voorwaarde voor suburbanisatie en scheiding van wonen en werken is de aanwezigheid van betaalbare vervoermiddelen om dagelijks afstanden die niet beloopbaar zijn te overbruggen. En op haar beurt is een toename van het verkeer het logische gevolg van deze veranderingen in de stedelijke structuur. In Amsterdam is sinds 1903, dankzij een uitbreiding van de dienstregeling en een daling

\footnotetext{
108 'Minder lawaai op straat!', De Telegraaf, 24-10-1933; 'Hoogtepunten uit het stadslawaai', De Telegraaf, 28-10-1933 (Archief van de Politie, toegangsnummer 5225, inventarisnummer 5686); 'Lawaaierig Amsterdam', Algemeen Handelsblad, 09-07-1939.
} 
van de prijs per rit, het reizen per tram niet langer voorbehouden aan de burgerij. Vanaf dat moment neemt het aantal passagiers fors toe en wordt ook het tramnet uitgebreid waarover tot in de jaren vijftig van de twintigste eeuw elke vijf minuten een tram rijdt (Buiter, 2005, pp. 189-198).

De tram heeft haar eigen geluid dat door een tijdgenoot zo wordt samengevat: "De tram te Amsterdam veroorzaakt rumoer door haar belgeluiden, door het bijslijpen der rails, door het stooten in de wissels, door het piepen in de bochten, bij het remmen en aanzetten, alsmede bij het passeeren van kruisingen." Als de tandwielen oud zijn, willen de wagens bij het "aanzetten, rijden en remmen" nog wel eens flink brommen en als ze nieuw zijn veroorzaken ze een onaangenaam loeiend geluid dat gelukkig "vermindert naarmate de tanden slijten en gaan inloopen."109

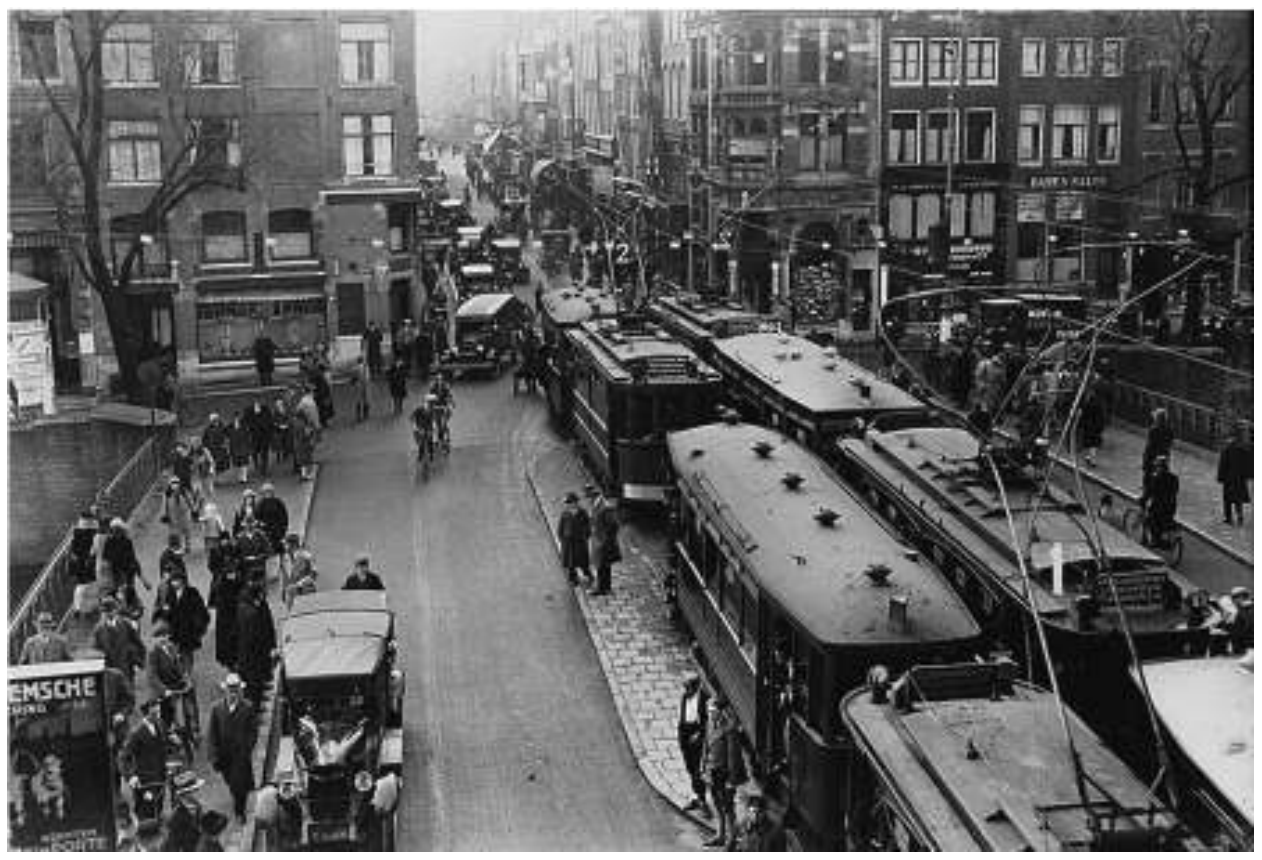

Afbeelding 7: Verkeer in de Leidsestraat ca 1929, voetgangers, fietsers, trams en auto's (Stadsarchief Amsterdam)

Naast de uitbreiding van het tramverkeer komen er steeds meer fietsen en auto's. De eerder genoemde 'sociale revolutie' brengt het kopen van een fiets binnen het bereik van een grote groep. Bovendien worden fietsen ook nog eens goedkoper. "Thans kost een goed rijwiel minder dan voorheen een stel banden; en men kan den kleinen prijs met geringe bedragen afbetalen" (Polak \& Vlugt, 1936, p. 194). In 1921 is er bijna één

${ }^{109}$ De Telegraaf, 18-10-1933; Algemeen Handelsblad, 22-12-1923. 
fiets per 8 inwoners en één auto per 300 inwoners, in 1930 zijn die aantallen één fiets per 3 , respectievelijk één auto per 100 inwoners. ${ }^{110}$

In 1931 telt men per dag in de Leidsestraat 33.000 voetgangers, 4800 auto's en 30.000 fietsen. Ter vergelijking: in 1885 trokken er gemiddeld per dag 22.000 voetgangers en 1000 voertuigen (rijtuigen, vrachtwagen en handkarren) door de Hartenstraat. ${ }^{111}$ De Leidsestraat is in de jaren dertig dan ook de straat met de meeste verkeersproblemen in Amsterdam. Eind 1929 wordt een automatisch belsysteem ingevoerd om de verkeersagenten te ondersteunen bij het sneller en regelmatiger door de straat voeren van het verkeer en in 1932 worden op het Leidseplein de eerste verkeerslichten in de stad geplaatst ${ }^{112}$ (Rooy, 2007a, p. 172).

Het verkeer heeft namelijk een zeer grooten omvang aangenomen, in het bijzonder in de oude stad. Talloos zijn de automobielen, taxi's, motorfietsen, bestel- en vrachtauto's, die de stad van vroeg tot laat doorkruisen - om van de nog in grooten getale aanwezige handkarren en de vele daarbij gekomen bakfietsen niet te spreken. Bij dit alles voegen zich de fietsers, die zich in tienduizendtallen door de stad bewegen en vooral in de vroege ochtend- en namiddaguren een schouwspel leveren, als wellicht geen andere stad ter wereld, zelfs Kopenhagen niet, te aanschouwen geeft (Polak \& Vlugt, 1936, pp. 140-141).

Zoals we eerder al zagen, brengen de veranderingen in voertuigen en bestrating en ook een toename van de verkeersdrukte niet per definitie in totaliteit een hoger

\footnotetext{
${ }^{110}$ In 1930 zijn er in Amsterdam op een bevolking van bijna driekwart miljoen inwoners: 6300 personenauto's, 3361 vrachtauto's, 220.000 fietsen, 2368 motorfietsen, 142 bussen, 12.000 handkarren, 2350 door paarden getrokken wagens en 2475 rijtuigen. Algemeen Handelsblad, 12-03-1930, 28-03-1930 en 27-081930; De Telegraaf, 27-02-1930. Na 1930 vlakt de toename van de bevolking en het aantal voertuigen af, maar het laatste in mindere mate. Een forse stijging is er wel nog in het aantal motorfietsen (van 2368 in 1930 naar 6946 in 1938). Verder zijn er in 1938 ongeveer 9860 personenauto's in Amsterdam (een stijging van $40 \%$ ten opzichte van 1930), 4044 vrachtauto's (stijging van 20\%), 272.500 fietsen (stijging van 23\%) en 214 autobussen (stijging van 50 \%). Archief van het Bureau voor Statistiek Amsterdam, inventarisnummer 887, p. 203.

${ }^{111}$ Algemeen Handelsblad, 12-03-1931; Archief Secretarie Publieke Werken Amsterdam, inventarisnummer 144, zaaknummer 1861.

112 “In 1929 inventariseerde inspecteur E.G.A. Bos de manieren om de regeling van het verkeer op de kruispunten te coördineren en te standaardiseren om het oponthoud terug te brengen en de rijsnelheid te verhogen. Bos ontwierp een systeem om de handelingen van de afzonderlijke verkeersagenten op elkaar af te stemmen met geluidssignalen, waartoe op ieder kruispunt aan een lantaarnpaal of tram mast een elektrische bel werd bevestigd. Twee keer bellen betekende het stopzetten van het verkeer in de Leidsestraat om het verkeer uit de zijstraten de gelegenheid tot rijden te geven. Eén keer bellen markeerde het weer vrijgeven van de Leidsestraat. De politie coördineerde de operatie vanaf een hoger gelegen etage op het Leidseplein" (Buiter, 2005, p. 204). Op 27 augustus 1930 vermeldt een artikel "De belsignalen in de Leidschestraat zijn nu ongeveer tien maanden in werking. (...) De leiders van het verkeer zijn over het algemeen tevreden (...) De belsignalen worden, als bekend, automatisch gegeven" Algemeen Handelsblad, 27-08-1930.
} 
geluidsvolume met zich mee, maar in ieder geval wel een veranderend klanklandschap. Die veranderingen zijn: minder geratel van karrenwielen over keien, meer geluid van motoren en van rubberen wielen over asfalt en veel, veel meer signalen van auto's, trams en fietsen.

Thans worden die wegen ook geruischloos gemaakt (als of er wegen bestaan die wel geruisch maken!) Men bedoelt dat het getoeter, gekrijsch, gesnauw en gerammel niet langer wordt gedempt door het lawaai der wielen. (...) De bewoners van de wegen waarlangs de auto's ijlen moeten zich maar het offer getroosten te worden opgeschrikt door het rammelend, krijschend, snauwend vehikel. Was het een lallende lawaaimakende voetganger - hem zouden forsche dienders ijlings wegrapen, maar wat rijdt, heeft een vrij-brief, en diens lawaai heeft den schijn van philanthropie: dat de slak-te-voet zich tijdig kan bergen (De Groene Amsterdammer, 24-10-1925).

Aan het einde van de negentiende eeuw was al duidelijk geworden dat de noodzaak om signalen te geven toeneemt naarmate voertuigen zelf minder lawaai veroorzaken en/of naarmate dat lawaai gemaskeerd wordt door andere geluiden. In Amsterdam moesten karren, rijtuigen en wagens dan ook worden voorzien van bellen als er sneeuw op de straten lag. ${ }^{113}$ Vanaf het begin van de twintigste eeuw doen zich vervolgens een aantal ontwikkelingen voor die leiden tot een forse toename van die geluidsignalen.

In de eerst plaats speelt het tempo waarin een voertuig voortbeweegt een rol: "Auto's en stoomfietsen moeten hun snelle nadering met seinen aankondigen." ${ }^{114}$ Dit leidt onder andere tot de gewoonte om te claxonneren bij zijwegen en zeker bij kruispunten in de stad, omdat deze doorgaans onoverzichtelijk zijn en er bovendien grote kans bestaat op ander verkeer. Onderstaande afbeelding van een sluitzegel, uitgegeven door de Amsterdamse verkeerspolitie in het kader van een actie ter verbetering van de verkeersveiligheid, laat zien hoe belangrijk men het geven van een signaal op elke straathoek vindt. "Geef goed signaal! Dacht u misschien dat iemand om een hoek kan zien!." Het zegel laat twee autohoorns zien die hun aankomst bij de hoek van de straat aankondigen met muzikale tonen.

\footnotetext{
${ }^{113}$ Zie hoofdstuk 3, paragraaf 'In de straat stijgt ratelend en schaterend het leven eener groote stad naar boven'.

${ }^{114}$ Het Vaderland, 24-02-1920.
} 

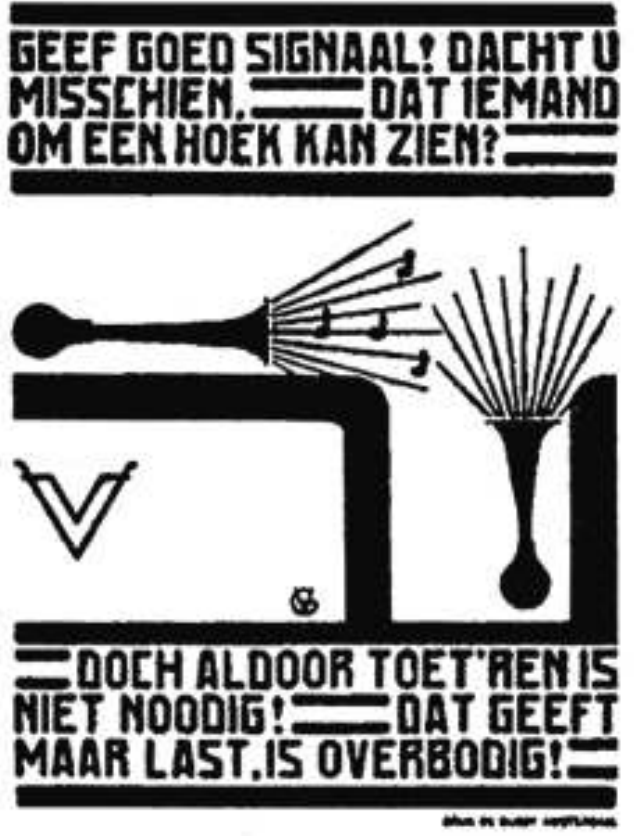

Afbeelding 8: Sluitzegelactie Veilig Verkeer (Algemeen Handelsblad, 18-4-1928)

Vervolgens treedt vanaf de jaren twintig de eerder genoemde groei op van het gemotoriseerde- en het fietsverkeer. De indeling van de wegen en de verkeersregels zijn echter nog niet afgestemd op die situatie en het gedrag van de meeste verkeersdeelnemers ook niet. Fietsers gebruiken de volle breedte van de rijweg, voetgangers zijn gewend om de kortste route te nemen en steken de weg over waar en wanneer hen dat uitkomt en het gemotoriseerde verkeer probeert zich al dan niet noodgedwongen een vrije doorgang te toeteren of te bellen.

Ik ken menschen, die toeteren uit bravour en ik ken er die signaleeren uit angst. Een angst, die ontstaat, doordat de rijder in kwestie zich achter het stuur niet veilig voelt. Weer anderen doen het uit gewoonte. Wanneer ieder signaal gaf zooals het behoorde, schoten we al een heel eind op. Het onnoodig signaleeren wordt sterk in de hand gewerkt, aangewakkerd zou ik haast zeggen, door de vraag, die iedere agent en iedere burger stelt en die men ook ter terechtzitting kan hooren: Hebt u wel duidelijk signaal gegeven? Om zich eventueel te kunnen dekken, laten honderden's nachts hun claxon brullen. Zelfs het publiek eischt, dat men het op een hoek van een straat laat schrikken. Vandaar dat men als automobilist zich dikwijls hoort toeroepen: Zeg, kan je niet toeteren? (De Telegraaf, 17-11-1930).

Het voortdurend signaleren zorgt er echter voor dat niet altijd duidelijk is wie toetert en waarom. 
De hoofdschuldigen zijn uw auto-claxons. Zij verscheuren en verzwakken $u$ het brein, en komen nimmer tot rust. Men heeft mij verteld, dat bij de wet is voorgeschreven, in uw steden den claxon veertig meter voor elken straathoek in werking te stellen. De verkeersveiligheid wordt daardoor toch waarlijk niet verhoogd. Integendeel, iemand, die de straat oversteekt, hoort dozijnen claxons, en de meeste gillen in denzelfden toon. Het is hem natuurlijk onmogelijk, daaruit de waarschuwing van een auto te halen, die nog veertig meter van hem af is, en daarom let hij er maar heelemaal niet op.... ('Wij maken teveel lawaai', De Telegraaf, 21-061933).

Vandaar dat het sluitzegel van de actie 'Veilig Verkeer' niet alleen oproept om goed te signaleren maar tegelijkertijd stelt dat "aldoor toet'ren" niet nodig is en enkel overlast veroorzaakt.

Het getoeter gaat ook een grote rol spelen in de antilawaai beweging van het interbellum. Dat geldt niet alleen voor Nederland maar ook voor de grote campagnes van andere Europese steden eind jaren twintig en begin jaren dertig (Bijsterveld, 2003, pp. 110, 117). In Amsterdam is het debat nauw verbonden met verkeersveiligheid en de vraag wie de straat toebehoort. De smalle straten, de vele kruispunten op korte afstand van elkaar en het groot aantal fietsers en handkarren zorgen voor een lokale kleuring van de discussie.

Immers het vele signaleeren vindt mede zijn oorzaak in de korte huizenblokken. Om de 30, 40, 50 meter zijn hier dwarsstraten. In het buitenland zijn de straatblokken veel langer. Als ze hier zoo waren als daar, zouden wij in de Leidschestraat veel goedkoper uit zijn met onze verkeerslampen ('Minder lawaai op straat!', De Telegraaf, 24-10-1933).

Het verkeer in Amsterdam is, vergeleken met dat in Londen, nog maar een spelletje. En nu maakt het al veel meer lawaai. Wat moet dat worden als er nog veel meer auto's in Amsterdam komen? (Algemeen Handelsblad, 10-01-1929).

Autobestuurders protesteren dat ze wel moeten claxonneren vanwege de handkarren die de straten blokkeren, de voetgangers die zonder te kijken de straat over steken en de fietsers die niet alleen de volle breedte van de rijweg gebruiken maar zich bovendien op kruispunten in drommen vóór de auto's opstellen. Omgekeerd beschuldigen fietsers en voetgangers de chauffeurs van een arrogante en lawaaiige toe-eigening van de straat. $^{115}$

\footnotetext{
${ }^{115}$ Algemeen Handelsblad, 28-02-1926, 07-11-1927, 18-08-1928, 10-01-1929; De Telegraaf, 17-11-1930, 3112-1930, 19-11-1931, 21-06-1933, 22-10-1933; De Groene Amsterdammer, 24-10-1925, 25-10-1930.
} 
Beschouwd vanuit de perspectieven van de 'ecologie', 'semiotiek' en 'politiek' van geluid zien we de volgende lijn van ontwikkelingen. De veranderingen in wegdek en voertuigen zorgen voor ander en in sommige opzichten voor minder geluid in de Amsterdamse straten, hoewel de groei van het verkeer deze tendens op den duur in ieder geval gedeeltelijk teniet doet (ecologie). De snelheid waarmee de voertuigen voortbewegen over de geasfalteerde en daardoor 'stillere' wegen vraagt vervolgens om het gebruik van waarschuwingssignalen (semiotiek). Ook omdat de intensiteit van het verkeer toeneemt en men nog niet vertrouwd is met de nieuwe verkeerssituatie. En tenslotte leiden de verkeersintensiteit en het gedrag van de deelnemers er toe dat de waarschuwingssignalen hun functie verliezen - door het vele signaleren is niet langer duidelijk wie toetert en waarom - en mede daardoor een rol gaan spelen in het gevecht om de straat. Voetgangers en fietsers beschouwen het getoeter als een symbool van de arrogantie van autobestuurders die menen de straat te mogen opeisen, terwijl chauffeurs protesteren tot claxonneren gedwongen te zijn door het onverantwoorde gedrag van voetgangers en fietsers (politiek).

De veranderingen beperken zich in Amsterdam echter niet alleen tot het geluid van wegverkeer. Door de opkomst van de dieselmotor verandert ook het geluid van het verkeer op het water. In de negentiende eeuw had de stoommachine er al voor gezorgd dat de aankomst en het vertrek van schepen heel wat Amsterdammers ter ore kwam dankzij het krachtige geluid van de stoomfluit, maar het geluid van door stoom aangedreven schepen op de grachten was blijkbaar beperkt gebleven of weinig opvallend. ${ }^{116}$ Met de dieselmotor lijkt dat te veranderen, vooral 's nachts.

Als bewoner der Leidschegracht weet ik er, helaas, van mee te praten. Uitvaren doen die kwelduivels meestal 's avonds, wat minder hinderlijk is, maar de stad invaren doen ze den geheelen nacht door, zoo ongeveer om het half uur, bij troepjes achter elkaar naar gelang ze door de Overtoomsche sluis geschut zijn. En het zijn niet alleen de motoren, maar ook de signaalhorens en bellen, die 's nachts, als alles overigens stil is, en men zoo'n schuit van zelf haast wel hoort varen, met zekeren wellust door de schippers schijnen gebruikt te worden (Algemeen Handelsblad, 07-07-1922).

\footnotetext{
${ }^{116}$ In de reisverslagen van De Amici, Wood, Harvard en de Coster, die aan het eind van de negentiende eeuw in Amsterdam verbleven, wordt de stoomfluit van schepen genoemd maar enkel Wood klaagt dat hij er wakker van wordt. Het geluid van de boten zelf komt niet aan de orde. Toch moeten er, op zijn minst zo nu en dan, stoomboten in de grachten gevaren hebben, want vanaf 1875 beschikte de stad Amsterdam over een varende stoombrandspuit (Rooy, 2006b, p. 473). Naast dieselmotoren werden er in deze tijd ook veel gloeikopmotoren gebruikt, die op petroleum, afgewerkte olie en vet liepen. "Ze werden met een benzinebrander van buiten opgewarmd, hadden een laag toerental en maakten een kenmerkend plof - plof - plof geluid. Ook wel knal - knal - knal." Met dank aan Warna Oosterbaan (email d.d. 13 maart 2013).
} 
Het blijft gissen hoe algemeen deze klacht is en wat er mee gedaan wordt. Bij het bespreken van de gemeentebegroting eind 1932 merkt een lid van de S.D.A.P. fractie op dat er vooral veel herrie op de Amstel is. Niet van vrachtboten maar van motorbootjes die met open knalpot varen. Er wordt echter niet gereageerd op deze opmerking. ${ }^{117}$ Vervolgens komt dit geluid in 1936 weer aan de orde in de raad als enkele leden het volgende naar voren brengen: "Dikwijls varen des nachts motorbooten met open knalpot door de grachten en veroorzaken hinderlijk lawaai." De Raad antwoord dat er bij de politie weinig of geen klachten binnenkomen over dit geluid, maar dat er aandacht aan geschonken zal worden. ${ }^{118}$

Het is overigens niet waarschijnlijk dat de groei van de gemotoriseerde vrachtvaart op de grachten gelijk is aan de toename van het wegverkeer. Het omgekeerde is eerder het geval. De groei van het wegverkeer en de uitbreiding van het tramnet leiden tot het dempen van grachten, het verlagen van bruggen en het vervangen van ophaal- door vaste bruggen. Dit verhindert het varen met grotere schepen en door de inkrimping van het waterwegennetwerk verslechtert de bereikbaarheid van bepaalde stadsdelen. Tegenover deze vermoedelijke afname van vrachtverkeer over de grachten staat vanaf de jaren twintig wel een forse toename van rondvaarten (Buiter, 2005, pp. 179-217). Per saldo zal gedurende de dag het geluid van motorboten in de binnenstad dus zeker zijn toegenomen.

Naast het verkeer op de weg en het water, is er sinds het gereedkomen van het Centraal Station in 1889 ook treinverkeer door de stad. Volgens de tabel van de winterdienst 1937/1938 rijden er op werkdagen tussen middernacht en 6 uur's ochtends 17 treinen op de lijn Amsterdam Centraal - Haarlem en vanaf 6 uur tot 10 uur's ochtends alleen al 45 treinen voor personenvervoer. ${ }^{119}$ Deze intensiteit van het verkeer, in die tijd nog veelal stoomtreinen, blijft verder tot middernacht nagenoeg constant (Jonckers Nieboer, 1938, bijlage N). Het geluid van de treinen komt echter nauwelijks aan de orde in teksten over het geluid van de stad, hoewel metingen uit 1938 (in decibel) op de lijn naar Haarlem (bij het viaduct in de Planciusstraat) laten zien dat de treinstellen verre van geruisloos zijn.

Amsterdam is een spoorwegstad en zelfs in den nacht klinkt overall het geruisch der treinen. Onder het viaduct hebben we en passant het geraas der rijdende trams. De kleinere wagens van lijn 23 noteerden 76, de groote van lijn 10, 78. De trambel was eveneens 78 en een man die op het viaduct aan het hameren was óók

\footnotetext{
117 'De begrooting van Amsterdam', Algemeen Handelsblad, 01-12-1932.

${ }^{118}$ Gemeenteblad 1936, Eerste Afdeeling, 15 Oct. 1936, pp. 1371, 1490.

${ }^{119}$ Ter vergelijking: in de winter van 1881/1882, toen de treinen naar Haarlem vanuit station Westerdok vertrokken (gelegen tussen het Centraal Station en het viaduct van de Planciussstraat), was er zowel op deze lijn als de lijn Weesperpoortstation - Utrecht tussen middernacht en 6 uur 's morgens helemaal geen treinverkeer en reden er gedurende de rest van de dag op beide lijnen maximaal 42 treinen (Jonckers Nieboer, 1938, bijlage M).
} 
78. Een vrachtauto dito, electrische hoorns onder het viaduct 84. De microfoon werd nu op het dak van den auto gelegd, in opwaartsche richting. Een goederenstoomtrein bracht het tot 81, een personenstoomtrein wat de locomotief betreft maximum 84, wat de wagens betreft ongeveer 78. Doch meer geraas maakte een snelle electrische personentrein naar Zaandam, n.I. 92. Een zelfde trein over het aangrenzende viaduct 81 decibel. De meter gaf zelfs duidelijk het verschil aan tusschen de motorwagens en de tusschenliggende rijtuigen zonder motoren ('Hoogtepunten uit het stadslawaai', De Telegraaf, 28-10-1933).

De tekst stelt dat het geluid van de trein ook in de nacht in grote delen van de stad waarneembaar is en bovendien dat stoomtreinen op dat moment minder geluid veroorzaken dan snelle elektrische treinen. Dit laatste zou kunnen betekenen dat de elektrificatie van het spoor rondom Amsterdam in de loop van het interbellum, in eerste instantie gepaard gaat met nog meer geluid van treinverkeer. ${ }^{120}$ Dat dit desondanks geen reden is om aandacht te besteden aan dit geluid, kan voor een deel verklaard worden door het feit dat het om een geluid gaat dat niet gemakkelijk als een 'sociaal probleem' kan worden gedefinieerd. De groep die het probleem 'veroorzaakt' is in dit geval bijvoorbeeld niet eenvoudig aanwijsbaar.

Net zoals het geluid van treinen wordt ook het geluid van verkeer in de lucht nauwelijks genoemd, maar nu omdat een luchtschip boven de stad nog een zeldzaam fenomeen is. ${ }^{121}$ In 1919 wordt aan de overkant van het IJ de Eerste Luchtvaart Tentoonstelling Amsterdam (E.L.T.A.) gehouden. Deze tentoonstelling is een enorm succes en trekt in zes weken tijd een half miljoen bezoekers (Rooy, 2007a, p. 150). In de vele krantenartikelen over deze tentoonstelling komt het geluid van vliegmachines en zeppelins nauwelijks aan de orde. Wanneer dat wel het geval is, is er sprake van

\footnotetext{
${ }^{120}$ De spoorlijn Amsterdam-Rotterdam werd in 1927 geëlektrificeerd, De lijn Amsterdam-Den Helder in 1931 en Amsterdam-Arnhem in 1938. Zie websites:

http://nl.wikipedia.org/wiki/Elektrificatie_van_spoorlijnen_in_Nederland

http://nl.wikipedia.org/wiki/Spoorlijn_Den_Helder_-_Amsterdam

http://nl.wikipedia.org/wiki/Spoorlijn_Amsterdam_-_Elten, geraadpleegd op 29 mei 2013.

${ }^{121}$ In de jaren twintig en dertig was de aandacht vooral gericht op het geluid in het vliegtuig. "Iedereen die per vliegtuig heeft gereisd weet hoe hinderlijk het oorverdoovend geraas is, dat hem op zijn tocht vergezelt. Zoo men aan het einde van een luchtreis van een paar uur al niet doof is, verkeert men toch gedurende eenigen tijd in een staat van verdooving, gewekt door de hevige geluidroffels van een sterken motor op de trommelvliezen." (Het Vaderland, 07-08-1930) Een beschrijving uit 1913 van het geluid van een vliegtuig, op dat moment een nog zelden gezien en gehoord verschijnsel, demonstreert hoe het geluid ook als een geruststelling kan worden ervaren. "Het geluid van den motor is de muziek, die hem aan ons bindt. Plotseling knettert de motor uit in een trage stilte, en het is de stilte die met diepe golven de ontroering weer in ons opstuwt, de ontroering en het opeens fel en scherp wordend begrip, dat de motor het leven en het hart is van den vlieger. ledereen weet, als in een huiver, nu de motor zwijgt, hoe de gonzende muziek daar boven de hoofden vertrouwen wekte." (De Groene Amsterdammer, 07-12-1913, p. 7). Zie ook (Bijsterveld, 2008, pp. 77-78).
} 
opwinding en bewondering. ${ }^{122}$ Als het grootste toestel van de tentoonstelling uiteindelijk in oktober vertrekt - eerder opstijgen blijkt vanwege de drassige ondergrond onmogelijk - vliegt het wel een kwartier lang laag over de stad. "Hedenmiddag - 't was ongeveer half drie - gonsden de vier zware Rolls Royce-motoren boven de stad. Op Damrak en Voorburgwal vlogen de deuren open; ieder snelde naar buiten of klauterde op het dak om het wonder der lucht te aanschouwen."123 Datzelfde gebeurt op 9 juli 1930, wanneer het Duitse luchtschip Graf Zeppelin onaangekondigd over Nederland vliegt. "Tegen 8 uur in den ochtend hoorden de bewoners van de hoofdstad een buitengewoon zwaar motorengeronk en duizenden liepen naar buiten of verschenen voor hun venster om te zien wat er aan de hand was."

Volgens Henry Polak - in deze periode lid van de Eerste Kamer voor de SociaalDemocratische Arbeiderspartij (SDAP) - roept de E.L.T.A. zoveel enthousiasme op dat in de gemeenteraad het voorstel wordt ingediend om van het tentoonstellingsterrein een vlieghaven te maken. Omdat men echter niet verwacht dat het zo'n vaart zal lopen met de luchtvaart, haalt het voorstel het niet. In de daarop volgende jaren blijkt dat de Raad het mis heeft; de luchtvaart maakt wel een snelle ontwikkeling door. Erg jammer, vindt Polak, dat Amsterdam haar luchthaven aan de overkant van het IJ is misgelopen. "Het heeft niet zo mogen zijn. Amsterdams luchthaven is ettelijke kilometers van de stad verwijderd. Onze stad staat dus in dit opzicht gelijk met vrijwel alle overige steden, die vliegvelden bezitten. Doch het had anders en beter kunnen zijn" (Polak \& Vlugt, 1936, p. 145).

\section{Geluid van wonen en 'arbeid aan den openbare weg'}

De suburbanisatie en de toenemende scheiding van werken en wonen zorgen in vergelijking tot de meer gemengde wijken van vroeger voor een toenemende differentiatie van klanklandschappen in de stad.

Is het lawaai werkelijk te erg? Dit hangt er van af, in welk gedeelte van de stad men zich bevindt. Wat Amsterdam betreft kunnen groote gedeelten in Zuid, West en Oost en Noord, ook vele grachten reeds terstond worden uitgezonderd; hier heerscht een haast dorpsche stilte, al wordt die - evenals in echte dorpen - wel eens door een schril autosignaal of een al te luidruchtigen straatventer onderbroken.

\footnotetext{
${ }^{122}$ Stadsarchief Amsterdam, Toegangsnummer 30486, inventarisnummer 698, bladen 3935-3936.

${ }^{123}$ Algemeen Handelsblad, 21-10-1919.

${ }^{124}$ Het Vaderland, 09-07-1930.
} 
Druk en roezemoezig is het natuurlijk in de binnenstad, althans van 8-8 uur ongeveer. Zou men dit anders wenschen? Het is de buurt der kantoren en winkels, waar weinig particulieren wonen (Algemeen Handelsblad, 14-04-1934).

Doordat het wonen geleidelijk uit de binnenstad wordt verdreven en er steeds minder paarden en karren worden gebruikt, verdwijnt daar het geluid van activiteiten die voorheen op straat werden uitgevoerd, zoals het beslaan van paarden, het kloppen van kleden en het repareren van kuipen en andere huishoudelijke voorwerpen. Dat gaat blijkbaar zo grondig maar ook ongemerkt dat Polak er eind jaren dertig met enige verwondering op terugkijkt: "Tot de eigenaardigheden van ons volksleven behoorde voorheen het verrichten van arbeid, het uitoefenen van ambachten aan den openbare weg (Polak \& Vlugt, 1936, pp. 280-282). Wel is tot in de jaren dertig de rateljongen te horen die bewoners waarschuwt dat de wagen die het huisvuil komt ophalen eraan komt. Volgens de meting in 1933 produceert een rateljongen een "muzikalen marsch" van 82 decibel, meer dan de gemiddelde 78 decibel van autohoorns. ${ }^{125}$ In de Jordaan en andere arme buurten wordt tot 1934 de komst van de 'Kar van Boldoot' op deze manier aangekondigd ${ }^{126}$ (Rooy, 2006a, p. 373).

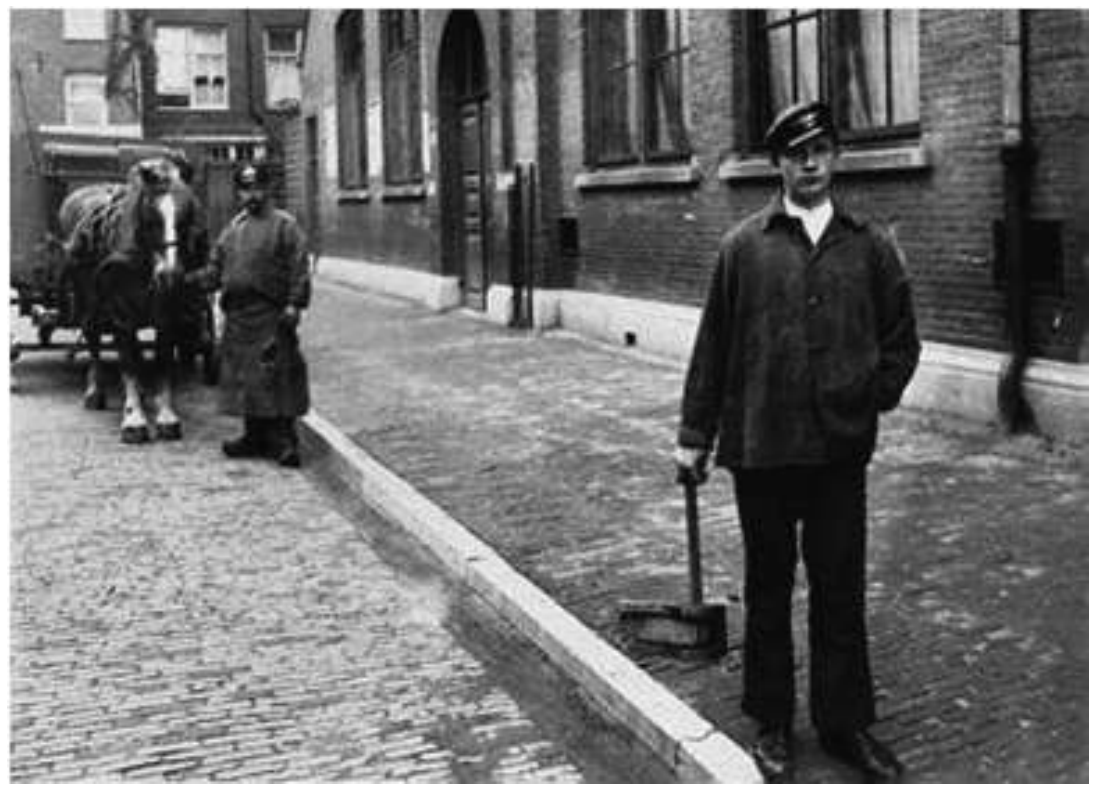

Afbeelding 9: Rateljongen ca 1920, op de achtergrond paar en wagen waarmee de vuilnis wordt opgehaald (Stadsarchief Amsterdam)

\footnotetext{
125 'Hoogtepunten uit het stadslawaai', De Telegraaf, 28-10-1933 (Archief van de Politie, toegangsnummer 5225, inventarisnummer 5686).

${ }^{126}$ De 'Kar van Boldoot' is een eufemisme voor de wagen die fecaliën komt ophalen. Boldoot is de naam van een 'Eau de cologne'-fabriek in Amsterdam.
} 
Afgemeten ratelend schrijdt de blauwgekielde vuilnisman van deur tot deur, onderbreekt even zijn roffel als hij aanbelt en gaat dan weer ratelend verder. Het knapt en kraakt tusschen de huizenmuren, het weergalmt in de diepe portieken en het brengt de glimmend gelapte vensterramen in trilling (Dekker, 1937, p. 11).

Ook het venten is in deze periode nog een gangbaar verschijnsel, al wordt deze vorm van 'arbeid aan den openbare weg' vanaf het einde van de jaren twintig streng gereguleerd en treedt er vanaf 1934 een uitstervingsbeleid in werking. De behoefte aan regelgeving hangt samen met problemen die ook elders in Nederland voorkomen maar in Amsterdam sterker gevoeld worden omdat hier veel meer venters werkzaam zijn. Zowel in absolute zin, als gemeten naar de omvang van de bevolking, telt Amsterdam tijdens het interbellum dubbel zoveel venters als Rotterdam, nummer 2 op de lijst. Bovendien gaan venters en verkeersdrukte slecht samen. Venters en hun karren hinderen zowel het rij- als het voetgangersverkeer en zorgen zo voor extra getoeter en gebel (Huberts, 1940, pp. 21-32, 52-56). Deze indirecte bijdrage aan het verkeersgeluid komt natuurlijk bovenop het eigen 'signaleren' van de venters dat, afhankelijk van de situatie, afgedaan wordt als "penetrant ordinair geschreeuw" ${ }^{127}$ of verheven wordt tot het vertrouwde geluid van elk Amsterdams stadsdeel.

Nog kennen wij den venter, die met zijn mand of kar vol fel kleurige bloemen of zachtglanzend fruit het vale beeld van een straat opvrolijkt en met zijn schallende roep het verkeersgeroes doorbreekt: de man, die om zijn karretje met lokkend belletje de jeugd verzamelt en haar voor enkele centen laat genieten van ijs met slagroom; de brutale uitdagende visventster, die met hartverscheurende roep haar springlevende waar aanprijst. Maar ook kennen wij de sjovele stakkerd, die door regen, wind en koude zijn karretje brandstof of lompen voortduwt en wiens roep nog slechts uit enkele onsamenhangende klanken bestaat (Huberts, 1940, p. 20).

Het enthousiasme en de ergernis over de roep van de venter heeft, vooral onder letterkundigen, een lange geschiedenis zowel in Nederland als elders. Willem Bilderdijk (1756-1831) had er een gruwelijke hekel aan, maar Everhard Potgieter (1808-1875) vond dat gemopper over die intrigerende klanken beneden de stand van een kunstenaar. Marcel Proust was eveneens enthousiast over de "cris des rues" en wijdde er een uitvoerige passage aan in zijn klassiek geworden roman $\grave{A}$ la recherche du temps perdu (Eijk, 2008, pp. 27-35). Ook musici toonden belangstelling voor deze klanken en, ondanks het feit dat ze in het interbellum nog volop te horen waren, werden er rond de overgang van de negentiende naar de twintigste eeuw al pogingen ondernomen om deze "straatroepen" te bewaren voor het nageslacht (Garms, 1909). Maar gezien het

${ }^{127}$ Algemeen Handelsblad, 09-07-1939. 
uitstervingsbeleid lijkt de ergernis over het geluid van de venters het uiteindelijk te winnen. We zullen hier in de laatste paragraaf van dit hoofdstuk op terugkomen.

\section{Klokken, spreekkoren en (straat)muziek}

Het geluid van de venters is overigens niet het enige dat op sterk uiteenlopende reacties kan rekenen. Ook straatmuzikanten worden of als onmisbaar, of als zeer hinderlijk beschouwd. Hun roep en hun muziek zijn uiteraard ook in de buitenwijken te horen, maar vanwege de aanwezigheid van veel publiek is de binnenstad voor hen een aantrekkelijk werkterrein. Zoals in de laatste paragraaf over de politiek van geluid zal worden toegelicht, zijn de klachten die uiteindelijk resulteren in allerlei beperkende bepalingen, dan ook voornamelijk afkomstig van kantoren, banken, hotels en winkeliers in de binnenstad.

In de eerste twee decennia van de twintigste eeuw worden aan straatmuzikanten niet meer dan dertig vergunningen uitgegeven. Dat aantal wordt in de loop van de jaren twintig iets meer dan verdubbeld, maar vermindert vervolgens vanaf 1934 aanzienlijk. Een jaar later mogen ze slechts één keer per dag op dezelfde plaats spelen en ook niet langer dan tien minuten. Die beperking komt bovenop al veel langer bestaande regels. Zo moeten ze onmiddellijk ophouden met spelen wanneer bewoners van een perceel dat vragen of wanneer er gedanst wordt. Vanaf de jaren twintig groeit bovendien de lijst van straten waar ze helemaal geen muziek mogen maken. Ondanks al deze beperkingen zijn in 1936 ongeveer 70 muzikanten actief in de binnenstad, waar inmiddels in 33 van de belangrijkste straten niet meer gespeeld mag worden. Het laat zich raden dat daardoor de klachten over hinder in de overblijvende straten enkel toenemen. Kort na het huwelijk van prinses Juliana en prins Bernhard in 1937 mag in de binnenstad geen enkel draaiorgel meer spelen en zijn voor de solospelers inmiddels 42 straten verboden terrein (Dijk, 1981, pp. 143-150).

De discussies die gedurende het interbellum over straatmuziek worden gevoerd vallen echter in het niet bij de commotie over de groeiende populariteit van jazz, film en Amerikaanse dansen als shimmy, foxtrot en de charleston. Mede dankzij de eerder genoemde 'sociale revolutie' en betrekkelijk lage prijzen neemt het bioscoopbezoek een enorme vlucht. In 1930 telt Amsterdam 32 bioscopen en vormen Rembrandtplein en Leidseplein de belangrijkste centra van het uitgaansleven (Rooy, 2007a, pp. 156, 164). Daar "spelen de damesorkestjes en de strijkjes hun geluid tot op het geoliede asfalt, waarover de taxis voortschuiven." ${ }^{128}$ Een jazzorkest dat in een danszaal op de Zeedijk speelt, klinkt voor zelfverklaarde 'verwende muzikale' oren als een grote kist die "voortgewenteld werd, waarin glasscherven, stukken blik en woedende katten tot een ijselijk geluidgevende massa dooreengehutseld waren" (Jong, ca. 1920, pp. 67-69). Film, moderne dans en jazz worden geassocieerd met barbarij en zedenverwildering.

\footnotetext{
${ }^{128}$ De Groene Amsterdammer, 25-03-1939.
} 
"Nationaal-socialisten, klassieke componisten en musici, protestanten, roden en roomsen, allemaal vervloeken ze de komst van de nieuwe Amerikaanse amusementscultuur" (Derks, 1991; Kaal, 2005; Wouters, 1999, pp. 16-17).

Die nieuwe Amerikaanse amusementscultuur heeft overigens ook haar eigen tegengeluid meegebracht naar Nederland. In reactie op de 'demoraliserende' invloed van ragtime- en jazzmuziek, die de mentale en lichamelijke zelfbeheersing zou ondermijnen, is er in de Verenigde Staten een reformbeweging op gang gekomen die 'good music' propageert. Men is er van overtuigd dat een algemene appreciatie van 'goede' muziek voor een stabiele samenleving zal zorgen, omdat deze muziek een manifestatie is van schoonheid, symmetrie en orde. ${ }^{129}$ De reformbeweging richt haar aandacht op scholieren, immigranten en gedetineerden en probeert onder andere met community singing te zorgen voor een verspreiding van de 'goede' muziek. (Campbell, 2000, pp. 263, 265, 267-272). Dit laatste middel probeert men ook in Amsterdam uit, maar het resultaat valt tegen.

Er is reeds een en ander gezegd over het lage peil, waarop de volkszang hier nog steeds staat. Eenige jaren geleden is men er, in navolging van Amerika en Engeland, toe overgegaan, bij voetbal-wedstrijden en andere gelegenheden, community singing in te voeren. Het heeft niet lang geduurd; thans hoort men in zulke bijeenkomsten weinig anders dan "We zijn niet bang" of "We gaan naar Rome". (...) Maar de invloed van de "muziek in blik", de mechanische muziek, de radio, is hier stellig niet zonder beteekenis - en de even onmiskenbare als algemeene daling van het peil der cultuur valt ook hierin te herkennen; de populariteit van de afgrijselijke jazz-"muziek" is een veelbetekenend symptoom (Polak \& Vlugt, 1936, p. 185).

Wellicht hoopt men dat het vertrouwde geluid van klokken en carillons, dat in de categorie 'goede muziek' past, enigszins helpt om de genoemde "daling van het peil der cultuur" tegen te gaan. Op verzoek van het genootschap Amstelodamum besluiten Burgemeester en Wethouder in 1922 dat "de trommels der speelwerken van de stadstorens in het vervolg zoo mogelijk ten minste eenmaal per jaar voor heel-uur-, half-uur- en kwartierspel van nieuwe melodieën voorzien worden." ${ }^{130}$ En verder is de muziek van klokken en carillons tijdens feestdagen te horen. Bij de viering van Koninginnedag in 1933, toen nog op 31 augustus, beschrijft een reporter hoe Amsterdammers die 's morgens nog op weg zijn naar hun werk op het Leidseplein even stil blijven

\footnotetext{
${ }^{129}$ In dit streven is een mix te herkennen van het oude paradigma van geluid (muziek versus niet-muziek en aandacht voor de bron van het geluid) en het nieuwe (muziek als een van de vele soorten geluid en aandacht voor de uitwerking op de mens). Het denken in termen van muziek en niet-muziek is herkenbaar in de relatie tussen muziek, symmetrie en orde. Maar anders dan in dat paradigma, gaat de aandacht nu uit naar de verheffende uitwerking van de 'goede' muziek - die zich door orde en regelmaat onderscheidt van alle andere muziek - op de kwetsbare delen van de bevolking.

${ }^{130}$ Het Vaderland, 23-03-1923.
} 
staan "om te luisteren naar de koraalmuziek van het peristylium van den Stadsschouwburg" en hoe later op de Dam "een handvol carillon-druppels verwaaien in den wind." ${ }^{131}$ Tijdens de kerstdagen van 1929 tenslotte, beschrijft een enthousiaste maar anonieme auteur de "wondermooie traditie" van "de inluiding van het kerstfeest op de klokken van het paleis op den Amsterdamschen Dam." Dankzij de radio is deze traditie, zo vervolgt de auteur "sinds eenige jaren in een nieuw kleedje gestoken; nu draagt de aether, door middel van de wondere radio, de tonen heel ver weg, is het niet meer noodig op den kouden winteravond op den Dam te staan." ${ }^{132}$

Toch is niet iedereen blij met deze torenmuziek, vooral bezoekers willen er nog wel eens van wakker liggen. In 1929 is er een verzoek aan de gemeenteraad om actie te ondernemen tegen de hinder van de torenklokken van de R.K. kerk op de hoek Rijnstraat en Lekstraat (Rivierenbuurt), maar dat wordt zonder enige vorm van discussie doorverwezen naar B\&W ter afdoening. Wel wordt in klachten uit Den Haag en Groningen over het luiden van klokken naar voren gebracht dat het carillon van de Munttoren in Amsterdam 's nachts niet meer te horen is. Het speelt sinds het begin van de jaren dertig niet meer gedurende de nacht in verband met de nachtrust van de gasten van het Carltonhotel. ${ }^{133}$ In Amsterdam worden er aan deze kwestie, los van een ietwat wrevelig gedicht, niet veel woorden gewijd. ${ }^{134}$ Het gedicht De nacht zij stom van P. Kloppers eindigt als volgt: "De nacht zij stom...... geen klokkespel/ Mag gasten in een groot hotel/ Hun paar uur slaap vergallen./ Maar ied'reen heeft in 't nacht'lijk uur/ Datzelfde recht...... en 't stadsbestuur/ Waarborge stilte aan Allen!!"135

$\mathrm{Na}$ de jaren twintig waarin het uitgaansleven wordt beheerst door moderne dansen, film en jazzmuziek, gaan in de jaren dertig internationale politieke verhoudingen een belangrijke rol vervullen in het culturele leven. Het wordt onrustig in de stad. Er zijn steeds vaker kleine opstootjes en rellen tussen communisten en fascisten. De NSB organiseert in 1934 en 1935 marsen door de stad en er wordt druk gecolporteerd. Dit leidt in 1934 tot een verbod op spreekkoren en op het luidkeels venten met drukwerk $^{136}$ (Dijk, 1981, p. 147; Rooy, 2007a, pp. 165, 210, 229-230). Massale bijeenkomsten met behulp van luidsprekers en life radio-uitzendingen zoals de nazi's in Duitsland organiseren, zijn er in Amsterdam niet. ${ }^{137}$ Desondanks moeten het gebruik van microfoon en luidspreker ook het karakter van publieke bijeenkomsten in Amsterdam hebben beïnvloed. Onder die omstandigheden kan een spreker immers door een

\footnotetext{
${ }^{131}$ Algemeen Handelsblad, 31-08-1933.

${ }^{132}$ Algemeen Handelsblad, 25-12-1929.

${ }^{133}$ Het Vaderland, 18-09-1930 en 06-09-1932; Klachtenbrieven Groningen 1936, nummers 35-39.

${ }^{134}$ In het register van het Gemeenteblad over de periode 1918-1939 komt het lemma 'carillon' slechts 1 maal voor. In dat geval gaat het over de weigering van B \& W om de arbeidersbeweging toestemming te verlenen om het carillon van de Zuiderkerk op 1 mei 1930 (dag van de arbeid) te (laten) bespelen.

${ }^{135}$ Algemeen Handelsblad, 21-09-1930.

${ }^{136}$ Gemeenteblad 1934, Derde Afdeeling, volgnummer 133.

137 In het hoofdstuk 'Affirmative Resonances in Urban Space" geeft Carolyn Birdsall een beschrijving van de organisatie van dergelijke manifestaties (Birdsall, 2010, pp. 35-72).
} 
groot aantal aanwezigen gehoord worden. Dat was eerder, zoals bij de demonstratie tegen de Vlootwet in 1923 in Amsterdam, niet het geval. ${ }^{138}$ In de maand september verzamelden zich toen tussen de 70.000 en 90.000 demonstranten uit alle delen van het land op het IJsclub terrein, het laag gelegen en op dat moment drassige terrein tussen Rijksmuseum en Concertgebouw.

Rondom het moeras waren hoge, ijle bouwseltjes opgesteld, van waaruit de sprekers het woord moesten voeren zonder microfoon. Toen de tijd was aangebroken, verzamelden zich rondom elk spreekgestoelte enkele honderden luisteraars, want het stemgeluid, ook dat van de luidruchtigste spreker was beperkt (Hulst, Pleysier, \& Scheffer, 1969, p. 121).

\section{Geluid van industrie en nijverheid}

Evenals dat aan het einde van de negentiende eeuw het geval was, 'horen' we in teksten uit het interbellum niet zoveel over het geluid van kleine en grote bedrijven. Wel wordt in een recensie van een concert van de futurist Luigi Russolo in 1921 in Parijs, met spijt geconstateerd dat ondanks de "geraasmakers" - muziekinstrumenten die hij heeft laten maken om het geluid van de moderne tijd te evenaren - de muziek "der machinale eeuw" helaas niet te horen is in Russolo's compositie en uitvoering. "Niets van de majestueuze, donkertonige scandeering van een machinefabriek. Niets van het rhythmisch pointillé van een scheepsbeslag of van een simpele schrijfmachine."139 Bovendien komen bij de eerder genoemde geluidsmeting in 1933, ook de persen van De Telegraaf op de Nieuwezijds Voorburgwal 225 aan de beurt. Het straatrumoer produceert 50 tot 60 decibel in de dan nog stille machinehal. "One press in operation 89, noteerde mr. Samuel. Toen nummer twee op toeren was, bleek het geluid toegenomen te zijn tot 92 , nummer drie 95, nummer vier 97 en nummer vijf 103." 140

Terugkijkend naar hun jeugdjaren als beginnend slijper of als kind van een briljantsnijder die thuis werkte, komen bij enkele joodse inwoners van Amsterdam wel herin-

\footnotetext{
${ }^{138}$ De Vlootwet was gericht op het uitbouwen en vernieuwen van de Marine met het oog op de verdediging van Nederlands-Indië. De wet werd op 26 oktober 1923 met slechts één stem verschil tegengehouden. In de daaraan voorafgaande periode tekende meer dan een miljoen Nederlanders, ongeveer een derde van de volwassen bevolking, een petitie tegen de wet (Anders, 2010).

${ }^{139}$ Het Vaderland, 20-06-1921.

140 'Hoogtepunten uit het stadslawaai', De Telegraaf, 28-10-1933. De mr. Samuel die in dit krantenartikel wordt genoemd is waarschijnlijk Harry P. Samuel, een ingenieur van Western Electric Holland. Zie (Bijsterveld, 2008, p. 174).
} 
neringen boven aan typische geluiden. Bijvoorbeeld aan het "geknars" van het slijpen en het intense geluid in de fabrieken. ${ }^{141}$

De diamantslijperijen waren onmogelijk nare fabrieken. In die oude fabriek van Boas hierachter in de Valkenburgerstraat zaten die mensen daar in lange zalen met allemaal een brede leren riem en met een ontzettend lawaai. Als de zon erop scheen was er geen lucht te krijgen en in mijn jeugd was dat de modernste fabriek die er bestond. ${ }^{142}$ (...) Het waren wel barre toestanden, maar het viel niet op omdat het voor iedereen moeilijk was, voor een heleboel mensen in ieder geval (Bregstein \& Bloemgarten, 2004, pp. 47, 49).

Uitgaande van de eerdere opmerking dat de economische ontwikkeling zich doorzet tot de jaren dertig en van Amsterdam een belangrijke industriestad maakt, zij het een industrie van vele kleintjes, doet vermoeden dat er toch heel wat bedrijvigheid te horen moet zijn. Dankzij de opkomst van de elektromotor in het begin van de twintigste eeuw, een krachtwerktuig dat ook voor kleinere bedrijven betaalbaar is, blijft het ambachtelijk kleinbedrijf wijdverbreid in de stad. Het kost de stedelijke overheid erg veel tijd om de bedrijven die overlast veroorzaakten te verwijderen uit de woonbuurten (Rooy, 2006b, p. 456). En vaak gebeurt ook het omgekeerde. Zo wordt bijvoorbeeld in 1930, op basis van een verordening uit 1926 "ter verdeling van de Gemeente in industrie- en woonwijken", het gebied tussen Singel, Brouwersgracht, Heerengracht en Korsjespoortsteeg, onttrokken aan het 'beschermde gebied' en tot gemengd gebied verklaard. ${ }^{143}$

\section{Buitenwijken, burengerucht en weekritme}

Het wonen verdwijnt dan ook geleidelijk naar de omringende wijken die tijdens het interbellum met grote voortvarendheid worden gebouwd. Deze 'voortvarendheid' zorgt helaas in een aantal gevallen voor zeer gehorige woningen, al merkt een tijdgenoot ook op dat de eisen die men aan wooncomfort stelt heel snel kunnen veranderen. In de krotten van de binnenstad was het niet ongebruikelijk dat men de onderburen kon zien lopen als er geen kleden op de grond lagen. "Dat waren gewone balklagen met een vloer en daar zaten spleten in; dus je kon elk woord van de buren horen" (Bregstein \& Bloemgarten, 2004, p. 125). Ook buiten de kamers, op de portalen "klinken min of meer duidelijk allerlei geluiden. (...) In een ander huis zaten ze met $z^{\prime} n$

\footnotetext{
${ }^{141}$ Ook in een publicatie over de woon- en werkomstandigheden van diamantbewerkers in Amsterdam wordt het geluid of lawaai in de fabrieken niet genoemd. Wel komen onhygiënische toestanden in de toiletten, was- en werkruimtes van de fabrieken aan de orde (Heertje, 1936, pp. 247-261).

${ }^{142}$ De Boasfabriek (huidig adres Nieuwe Uilenburgerstraat 173-175) beschikt over grote ramen om te zorgen voor zoveel mogelijk daglicht.

${ }^{143}$ Gemeenteblad 1930, Eerste Afdeeling, pp. 2435-2444.
} 
vijven in een klein vierkant kamertje, ofschoon er achter een zee van 'n kamer (voor Jordaanse begrippen) nog disponibel was. Het waren alle vijf volwassenen. De mannen rookten en allen dronken thee, uit grote witte kommen. Ook ik kreeg m'n deel. Luid daverde radiomuziek door de kleine ruimte. Hard schreeuwden ze nu en dan er ' $n$ opmerking door heen" (Dijkhuis, 1939, pp. 66, 69).

Een deel van de bewoners van deze krotten komt later in de Transvaaltbuurt terecht, waar men ondanks het feit dat de huizen nieuw en beter geconstrueerd zijn toch (op de duur) last krijgt van burengerucht. "De vermelding van de geluidsoverlast in de 'frisse' nieuwe woningen wijst erop, hoe snel de grenzen van wat men van wooncomfort kan verlangen, verschuiven. Er waren nogal wat piano's in die huizen en het was er 'verdoemelijk gehorig'. Van eenhoog kwam het met walsen door de vloer omhoog, van driehoog onhoudbaar met z.g. salonstukken door het plafond naar beneden" (Presser, 1974, pp. 47-51).

Naast het geluid van musicerende en van vrome buren ${ }^{144}$ blijkt vooral de radio voor veel burengerucht te zorgen. In 1935 treft men in Amsterdam in 65 van de 100 woningen een radiotoestel aan; in 1939 is dat bijna 70 toestellen per 100 woningen. ${ }^{145}$ Zoals de afbeelding op de volgende pagina laat zien, heeft de radio aan het eind van de jaren dertig veel te bieden. Naast muziek zijn er naai-, taal- en gymnastieklessen, beursberichten, politiek nieuws en populaire amusementsprogramma's als 'De bonte dinsdagavond trein'. ${ }^{146}$ Cursussen en vragenrubrieken zijn vooral gericht op vrouwen en kinderen. Omdat zij de meeste tijd thuis doorbrengen, vormen zij de doelgroepen die het meest interessant zijn voor de radio. Vanaf 1924 zijn er programma's speciaal voor kinderen en verder "knipte, kookte, breide en tuinierde men er in de middaguren lustig op los" (Wijfjes, 1994, p. 64). In uitzendtijd gemeten is er echter de meeste ruimte voor amusement en lichte muziek. Ondanks de ideologische aspiraties van programma-instanties is de radio, zoals luisteronderzoeken in 1936 en 1938 bevestigen, in de eerste plaats een middel tot vermaak en verpozing (Wijfjes, 1994, p. 70).

\footnotetext{
144 "Al voor zeven uur 's ochtends begon het gezin hartstochtelijk en luid in het Hebreeuws te bensjen (bidden) en fungeerde zodoende voor ons, de bovenburen, ongewild als wekker. Op joodse feestdagen zongen de Hillesums de bijpassende liederen en liedjes met grote overgave, maar crimineel vals" (Bregstein \& Bloemgarten, 2004, p. 64).

${ }^{145}$ Gemeente Amsterdam, Statistisch Jaarboek 1935-1939, p. 368. Voorafgaande edities van de Statistische jaarboeken van de Gemeente Amsterdam bevatten helaas geen cijfers over radiobezit of gebruik in de stad.

146 'De bonte dinsdagavondtrein' is van 1936 tot 1940 en van 1945 tot 1957 een van de populairste radioprogramma's. Het programma dankt zijn naam aan drie belangrijke elementen van het programma: het heeft de vorm van een bonte avond, het wordt op dinsdag uitgezonden en het publiek wordt per trein naar Hilversum vervoerd. De bonte dinsdagavondtrein is in 1936 het eerste programma mét publiek in de studio. Zie website http://www.beeldengeluidwiki.nl/index.php/De_bonte_dinsdagavondtrein, geraadpleegd op 21 juni 2013.
} 
Gehorige huizen en open ramen zorgen er voor dat er soms wel tien of twaalf toestellen tegelijk te horen zijn. ${ }^{147}$ Dat leidt vaak tot klachten en onenigheid tussen buren, maar soms maken ze er ook gebruik van.
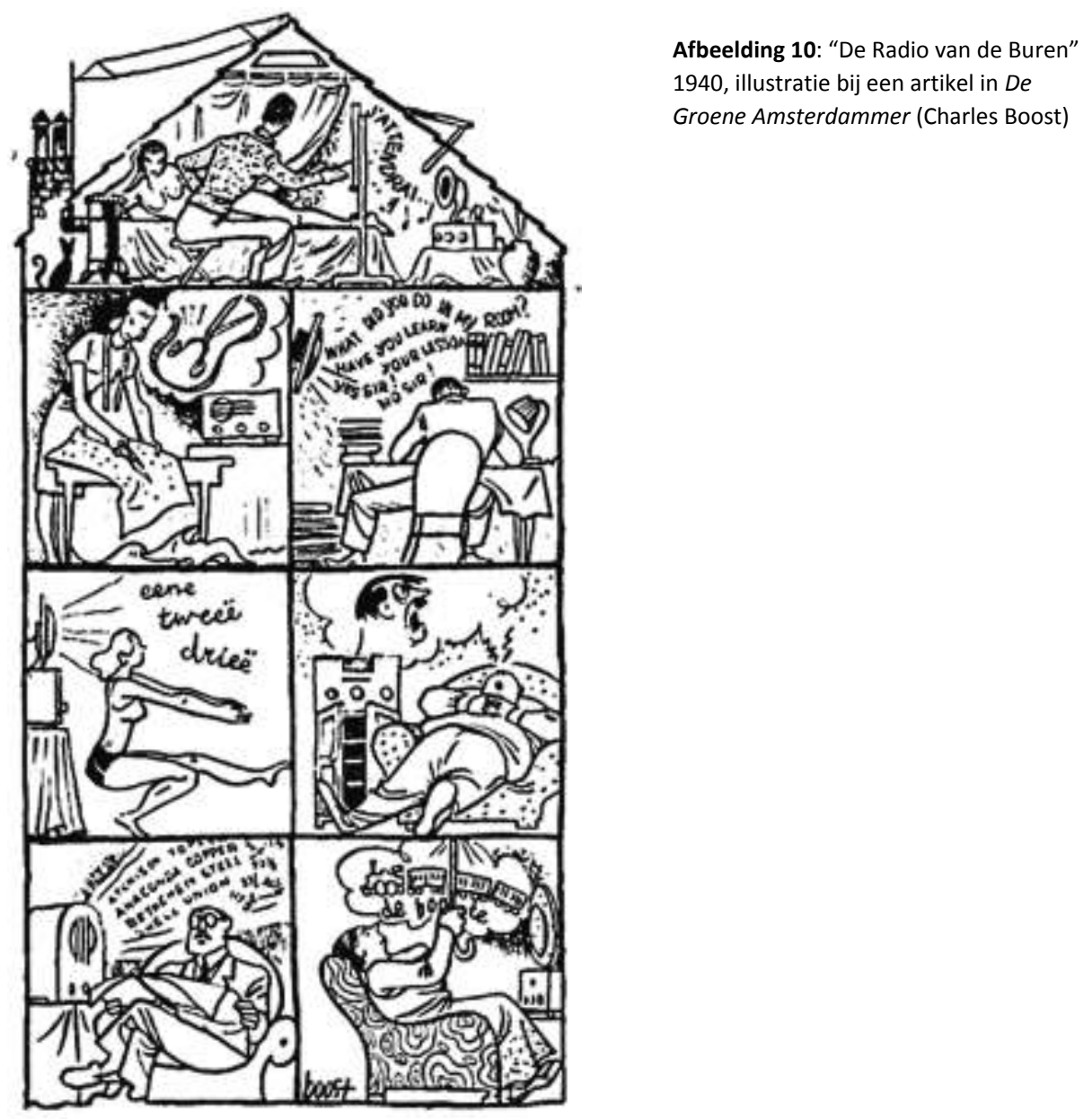

Voor de massa is de radio niet meer middel, zij is doel. Men schakelt het toestel in en het onverbiddelijke mechanisme doet zijn plicht en ....men heeft muziek (of wat daar voor door gaat!), of een preek of wat anders. En onze muziek-minnende Radio-vrienden behoeven naar dit alles niet eens te luisteren! Men kan zo heerlijk van alles doen bij die radio: gezellig met een heele kamer vol menschen zitten praten en lachen, heel aangenaam een kaartje leggen, men kan er bij hameren of zagen, ja, men kan er zelfs, zoo 's avonds na het eten, "zoo heerlijk een uurtje bij slapen"

${ }^{147}$ Gemeenteblad 1929, Tweede Afdeeling, p. 2740. 
(historisch!). De loudspeaker liefst op volle kracht, vult de kamer, neen, M.de R., vult het heel huis met lawaai! Met een bijna onafgebroken jengelend geluid, dat door muren en vloeren heendringt, en dat de buren, die na een inspannende dagtaak 's avonds behoefte hebben aan rust in de huiskamer, gewoon wanhopig maakt (Brink, 1929).

De Nederlandse volgelingen van Hitler en consorten vond men over het algemeen belachelijk. Maar nog meer op de lachspieren werkte de grote dictator zelf, als deze zich via de radio tot zijn volk richtte. In onze straat stemden dan heel wat joodse bewoners hun toestel af op een Duitse zender. En bij mooi weer, als de ramen openstonden, schalde Hitlers via vele ontvangers gereproduceerd hysterisch gebrul dan extra hard de straat in. Maar in plaats van dat dit gebrul de joden in onze omgeving angst inboezemden, maakten zij zich er vrolijk over. Het besef dat Nederland zelf, en in het bijzonder de joden in ons land, in een dreigende onveilige situatie verkeerde, drong vóór 1940 trouwens slechts tot weinigen door (Bloemgarten, 2003, p. 67).

Vanaf 1929 worden er wijzigingen aangebracht in de Amsterdamse politieverordeningen naar aanleiding van klachten over hinder veroorzaakt door radio, grammofoons en muziekinstrumenten. Maar het blijkt een onderwerp te zijn waarover de meningen uiteen lopen en dat bovendien niet gemakkelijk via verordeningen is te regelen. In eerste instantie volgt Amsterdam het voorbeeld van de Rotterdamse maatregelen die alleen gericht zijn op het tegengaan van overlast door radio en grammofoon. Overlast van traditionele muziekinstrumenten wordt niet meegenomen in de maatregelen, omdat musici in tegenstelling tot de radio en de grammofoon niet eindeloos kunnen en zullen spelen. Raadslieden die tegen de maatregel zijn, voor het merendeel van politiek linkse signatuur, vinden het onaanvaardbaar dat op deze manier een wettelijk onderscheid wordt gemaakt tussen de muziek van de arbeiders (via grammofoon en radio) en de bourgeoisie (muziekinstrumenten). Vanaf 1931 verdwijnt dit onderscheid dan ook in de verordeningen en worden ook muziekinstrumenten genoemd als potentiële bron van overlast (Bijsterveld, 2008, pp. 166-171). Desondanks heeft men van meet af aan twijfels over de toepasbaarheid in de praktijk. Al in 1929 werd bij de bespreking van de verordening in de gemeenteraad vastgesteld dat handhaving buitengewoon moeilijk zou zijn. ${ }^{148}$

In 1940, twee maanden voor het uitbreken van de oorlog en tien jaar na de invoering van de verordening, schrijft H.B. Fortuin, auteur en redacteur bij De Groene Amsterdammer, een artikel getiteld 'De radio van de buren...' waarin hij zich een voorstelling maakt van de toepassing van de verordening. ${ }^{149}$ "U belt dan dus Uw sectie-

\footnotetext{
${ }^{148}$ Gemeenteblad 1929, I, p. 2032.

${ }^{149}$ Afbeelding 8 is de illustratie bij dit artikel.
} 
of afdeelingsbureau op en een voorkomend agent of inspecteur treedt met mannelijke stap Uw woning binnen, legt het politioneele oor te luister, vindt het "hinderlijk", en praat vaderlijk edoch vermanend met Uw martelaars" (Fortuin, 1940). Volgens Fortuin heeft de Amsterdamse verordening in die tien jaar tot twee à drie veroordelingen geleid. Toch geven van de tien willekeurige mensen die hij de vraag stelt, er vijf aan dat de doordringende muziek een ernstige belemmering is voor hun levensgeluk. Hij vraagt zich dan ook af of de enige mogelijke oplossing voor dit probleem het verhuizen "in de eenzaamheid" is.

Verrassend genoeg leven er enkele jaren eerder, in 1937, plannen in Amsterdam om een speciaal voor de Amsterdamse verkeerspolitie in Delft ontwikkelde lawaaimeter, de Silenta genaamd, ook te gaan gebruiken voor het meten van de radiohinder en andere vormen van burengerucht. Maar deze veronderstelde objectivering van de "hinder" wordt in de pers meteen de grond in geboord. Men is niet alleen van mening dat de context en betekenis van een geluid een belangrijke rol spelen bij hinder, maar bovendien dat stadsbewoners elkaar het recht moeten gunnen om geluid te maken (Bijsterveld, 2008, pp. 179-180). Deze twee uitersten van aan de ene kant de stadsbewoner die door de muziek van zijn buren ernstig gehinderd wordt en aan de andere kant de bewoner die vindt dat dat geluid bij de stad hoort en dat het een kwestie is van 'leven en laten leven' komt bij de bespreking van de antilawaai beweging hieronder opnieuw aan de orde.

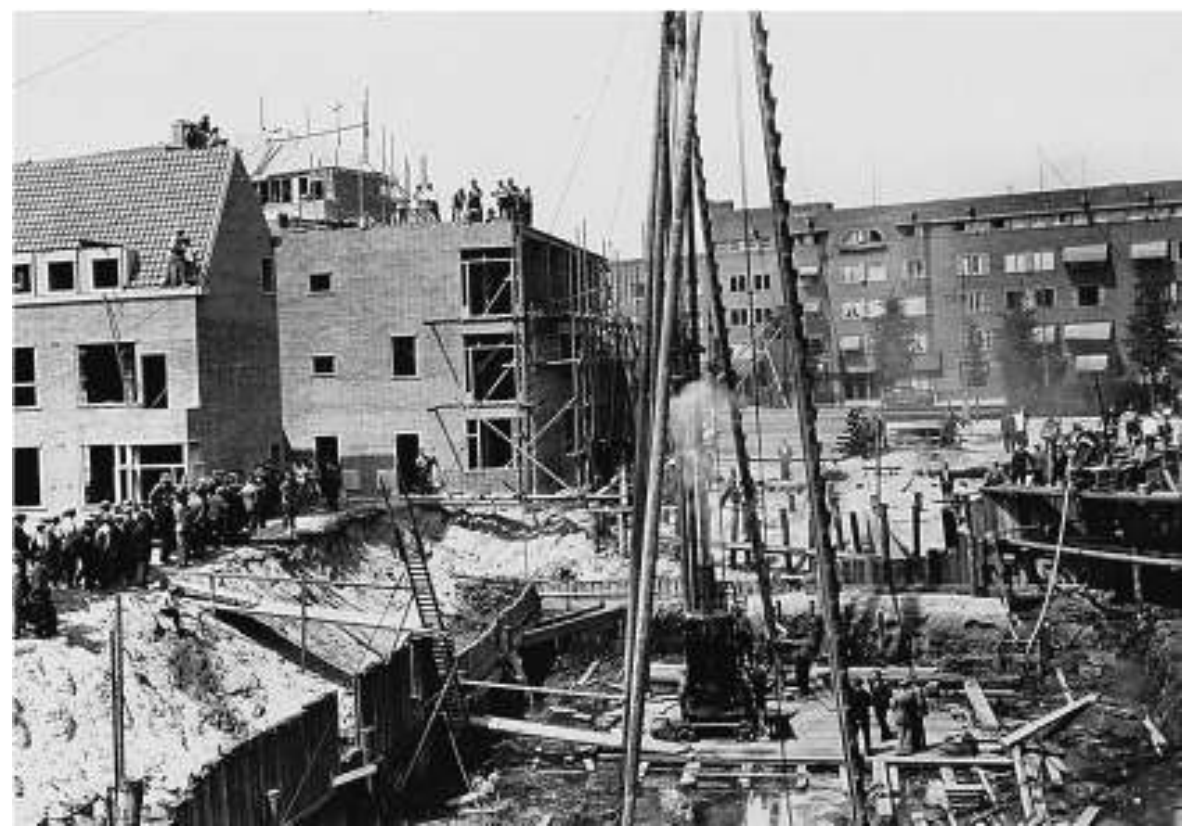

Afbeelding 11: Heien met behulp van een stoomheiblok op het Daniël Willinkplein (tegenwoordig Victorieplein) ca juli 1930 (Stadsarchief Amsterdam) 
Het uitbreiden van de stad met nieuwe woonwijken brengt uiteraard ook allerlei specifieke geluiden met zich mee en zorgt voor situaties die vergelijkbaar zijn met de aanleg van het Olympisch stadion medio 1926:

Dan denk je te wonen in een stillen hoek, in het vredige nieuwe "Zuid" ver van het rumoer, dat eigen is aan de moderne stad - neen, niet alleen moderne, want Vondel had het al in zijn "Wildzang" over het "stad- en straatgeschril" - en je komt opeens tot de ontdekking, dat je woont in een "havengebied". Door de nachtelijke stilte klinkt sirenengeloei; je schrikt wakker, na een wilden wek-droom van mailbooten in den mist. Je tracht het geluid te definieeren, zoekt nog naar een oplossing, als weer de sirene brult. Nu heb je zekerheid. Stoombooten (...) eenvoudige, kleine sleepbootjes, sterk genoeg toch om acht volgeladen zandbakken te slepen en in staat om heel wat lawaai te verwekken met de sirenen. Er is méér verkeer in het kanaal. Zolderschuiten brengen materialen aan voor den bouw van de bruggen, voor rioleering, bestrating, woningbouw, tegenover de Vinkeleskade, de van Goyenkade en de Lastmankade ligt het vol met vaartuigen van allerlei aard, in lossing (Algemeen Handelsblad, 03-03-1926).

Anders dan in de vroegere overvolle buurten in de binnenstad, waar een deel van het leven zich noodgedwongen op straat afspeelde en wonen en werken in elkaars nabijheid vertoefden, is het (als er niet gebouwd wordt) in de woonwijken vrij rustig. Kinderen spelen op straat, als het verkeer dat tenminste toelaat, en verder wordt de rust zo nu en dan verstoord door venters, straatmuzikanten en de vuilniskar. ${ }^{150}$

De enige uitzondering op de relatief rustige woonwijken is de 'sterk proletarische' Transvaalt buurt waar zich net als in de oude Jodenbuurt een uitgesproken straatleven ontwikkelt. Met het uitbreken van de Tweede Wereldoorlog komt er voorgoed een einde aan dit straatleven en het bijbehorende weekritme (Bloemgarten, 2003; Presser, 1974).

Tegen elf uur gaan de lichten achter de gordijnen in alle huizen laag branden. Over de huizen daalt de grote stilte. Het rumoer van de drukke werkweek is al uren ge-

\footnotetext{
150 In Den Haag en Groningen worden vooral de bakkerskar en de bel van de ijscoman aangewezen als rustverstoorders. De laatste is dat meestal 's avonds als hij kinderen uit hun slaap houdt, de eerste gedurende de ochtend. "Maar wat mij steeds verwondert en ergert is, dat zich nimmer een stem verheft tegen de schokkende geluiden welke de broodbezorgers telkens laten daveren als zij, om brood af te leveren, hun kar openen en het deksel met een geweldigen smak weer laten dichtvallen." In 1935 komt de firma Lips met een 'Anti-lawaai-rem' voor bakkerskarren op de markt die "een einde maakt aan het hinderlijke klappen van de deksels van broodkarren e.d." Hoewel mij uit deze periode geen Amsterdamse klachten over bakkerskar en ijscoman bekend zijn, lijkt het waarschijnlijk dat dit soort geluiden in alle Nederlandse steden te horen moet zijn geweest. Het Vaderland, 03-07-1920, 11-08-1930, 12-08-1930, 24-03-1934, 24-08-1935, 21-09-1935 en 25-05-1936; Klachtenbrieven Groningen 1936, nummers 9, 17, 20, 42, 44, 55, 63, 76, 79, 87 en 89; Het Vaderland, 12-08-1930 en 21-09-1935.
} 
leden verstomd. Nu zwijgt ook de luidruchtige innigheid van het gezinsleven. Het is alsof over de hele buurt een grote glazen stolp wordt gezet, die alle gerucht van buiten afsluit. De grote rust van de vrijdagnacht breekt aan, die overgaat in de roerloosheid van de Sjabbesmorgen. Geen gerucht van mensen op straat. Geen gekraak van handkarren. Geen kinderen, die naar school gaan. Alleen wat vrome mannetjes, die naar 'sjoel' schuifelen, onder de arm de fluwelen zak met het gebedskleed" (Sluyser \& Drees, 1957, p. 63).

Een weekritme, bestaande uit zes werkdagen en één rustdag, is overigens in Amsterdam in de jaren twintig nog een betrekkelijk recent fenomeen. Pas in 1917 wordt in de gemeenteraad een voorstel tot het verbod op zondagsarbeid aangenomen en verspreidt zich de zondagsrust "opnieuw wat steviger over de gehele stad" (Rooy, Bosscher, Bloemgarten, \& Carasso-Kok, 2007, pp. 103-104). Aan deze rust op zondag gaat vooral in de Jordaan een vrolijke drukte op zaterdagavond vooraf.

Op Zaterdagavond door de Jordaan. Nergens wellicht, in heel Amsterdam niet, drukt de zaterdagavond met z'n aparte stemming en bezigheid zó sterk z'n stempel als in deze arbeidersbuurt. Zes grauwe sloofdagen zijn voorbij. Dagen van zich moewerken, in zweetkleren rondlopen, vroeg opstaan en krap bij kas zitten. Nu is het Zaterdagavond - de lijfkleren zijn verschoond, de beurs is vol en ... morgen is het Zondag. Uit alles slaat je de vreugde ervan tegemoet. Uit ieder oog, uit iedere lach. leder manifesteert het op zijn manier. Ze weten ' $m$ te waarderen, de zaterdagavond. Evenzo als ze de Maandagmorgen kunnen haten! Het sentrale punt; of liever; de sentrale lijn is de Lindegracht. Op het middentrottoir van de nu gedempte gracht staan de kraampjes in 'n dubbele rij opgesteld. Daartussen twee mensenstromen. Arbeiders-mensen van allerlei slag. (...) Overal; geschreeuw van aanprijzingen. Het ene nog overtuigender dan het andere. Het rumoer en de drukte verdoven eerst even het waarnemingsvermogen (Dijkhuis, 1939, p. 59).

Zoals eerder genoemd vertoont de Jodenbuurt en de Transvaaltbuurt ook zo'n ritme, maar dan een dag vroeger: "Vrijdagavond was het er feestelijk druk. (...) Zaterdags lag de joodse wijk als een eiland van rust temidden van de grote stadsdrukte" (Roegholt, 1976, p. 113).

De Tweede Wereldoorlog betekent niet alleen het definitieve einde van dit 'eiland van rust' in de Amsterdamse zaterdag, maar tevens het voorlopig einde van een lawaaiig straatfeest, ook op zaterdag, dat Luilak wordt genoemd en erg populair is bij Amsterdamse kinderen. ${ }^{151}$ In de vroege ochtend van de zaterdag voor Pinksteren gaan de kinderen de straat op om "slaaplustigen onder luid geroep van 'luilak' en met door

\footnotetext{
${ }^{151}$ Volgens het Meertens instituut wordt dit gebruik na de oorlog in Amsterdam weer opgepakt. Zie website http://www.meertens.knaw.nl/meertensnet/wdb.php?sel=79973, geraadpleegd op 21 juni 2013.
} 
potten en pannen voortgebrachte ketelmuziek minimaal uit hun slaap te wekken en maximaal in woede te doen uitbarsten" (Bloemgarten, 2003, p. 59).

\section{Politiek van geluid in het interbellum: Weerklank van veranderend stadsleven?}

Geluid kan op twee manieren voor 'politieke' doeleinden worden ingezet. In de eerste plaats kan er geluid worden gemaakt om zo aandacht te krijgen of een reactie op te roepen. Ten tweede kan geluid dat anderen maken worden aangegrepen om een bepaalde situatie aan de kaak te stellen en eventueel te veranderen. De vragen die aan het begin van dit hoofdstuk zijn geformuleerd over de politiek van geluid in Amsterdam tijdens het interbellum, hebben betrekking op de laatste verschijningsvorm. Voordat we verder gaan met deze vragen, staan we eerst even stil bij het maken van geluid als politiek middel.

Een onschuldige vorm van deze vorm van 'politiek' in Amsterdam is het straatfeest 'Luilak'. Het geeft kinderen, zij het maar één keer per jaar, de macht om volwassenen uit hun slaap en mogelijk uit hun bed te halen. Afgaande op een krantenbericht uit 1923, kan het net zo onschuldig ogende 'wakker maken' van 'beter gesitueerde' Amsterdammers echter ook als een serieuze verstoring van de openbare orde worden gezien en een felle tegenactie oproepen.

In den laten namiddag van gisteren verspreidde zich het gerucht, dat het Werklooze-agitatie Comité, het z.g. W.A.C., in de nachtelijke uren zou gaan demonstreeren in enkele wijken der gegoeden, ten einde den schrik onder de beter gesitueerden te verspreiden. (...) Die zouden daarin bestaan dat in verschillende straten troepen van twintig, dertig man, hard trappend op het plaveisel heen en weer zouden loopen om daardoor de bewoners uit den slaap te wekken.

Door deze demonstraties meenden de W.A.C.-leden zooveel ontsteltenis in die gegoede wijken teweeg te brengen, dat de op heden, Zaterdag, voorgenomen collecte voor de agitatiekas, al zou het dan ook heeten: "Voor de werkloozen", in die straten heel wat zou opbrengen ('Stadsnieuws. Mislukte W.A.C.-betoogingen', Algemeen Handelsblad, 06-01-1923).

De ongeveer honderd "betoogers" die zich tegen middernacht bij het Vondelpark verzamelen worden door een cordon van politieruiters, manschappen en rechercheurs te voet en de inspecteur van de motorbrigade met zijn zijspan omsloten en vervolgens uiteen gedreven. Als dat niet snel genoeg gebeurt vuurt een van de rechercheurs met zijn revolver twee signalen af en komt er hulp van nog meer manschappen. Met hoefgetrappel, motorgeluid en revolverschoten 'voorkomt' men dat de bewoners van 
"gegoede wijken" door het gestamp van de betogers uit hun slaap worden gewekt. Hoewel de reporter laat doorschemeren dat hij deze vorm van ordehandhaving overdreven vindt, hij merkt op dat "wij" inmiddels weten dat de hoofdcommissaris een vijand is van halve maatregelen, lijkt er een serieuze dreiging uit te gaan van deze vorm van 'politiek van geluid'. Een andere verklaring zou kunnen zijn dat men actievoerders met deze felle politieactie voor eens en altijd de moed wil ontnemen om dit soort betogingen te organiseren. Voor zover ik weet is deze vorm van actievoeren in Amsterdam namelijk nooit herhaald. Hoe het ook zij, zowel het felle ingrijpen van de politie als het gegeven dat de betogers voor deze vorm van actievoeren hebben gekozen toont aan dat zoiets simpels als het geluid van stampende voeten in de nacht een politieke boodschap kan uitdragen.

Het koste wat het kost willen bestrijden van het geluid van stampende voeten in de nacht, desnoods met hoefgetrappel, motorgebrom, revolverschoten en het geluid van stemmen, wijst er ook op dat een oordeel over het al dan niet gewenst zijn van een geluid voor een belangrijk deel samenhangt met het oordeel over de oorzaak of bron van dat geluid. Het onregelmatige en af en toe luide geluid van de politieactie in de nacht mag er zijn, het ritmische getrappel van de schoenzolen van de werklozen niet. De puur fysieke kwaliteiten van een geluid, zoals de luidheid of de regelmatigheid, doen er dus veel minder toe dan we in eerste instantie zouden verwachten. $\mathrm{Er}$ moeten dus andere 'goede' redenen zijn waarom sommige Amsterdamse stadsgeluiden in het interbellum wel worden bestempeld als ongewenst en dus als lawaai en andere niet. Voordat deze redenen aan de orde komen, kijken we eerst naar het soort geluiden waaraan in teksten aandacht wordt besteed en naar de manier waarop dat gebeurt.

Analyse van krantenartikelen en brieven waarin het geluid van de stad als onderwerp aan de orde komt of zijdelings wordt genoemd, geeft geen aanleiding om te constateren dat er tijdens het interbellum een specifiek Amsterdams repertoire van geluiden bestaat waarover men spreekt, discussieert of klaagt. Claxons, open knalpotten, motoren, radio's, venters, straatmuzikanten, trams, wagens, carillons, hanen, katten, pianospelende buren, zingende dienstmeisjes en mattenkloppers 'hoort' men in die tijd in Amsterdam, maar ook in Groningen en Den Haag en over de eerste zes in het rijtje wordt overal het meest geklaagd. ${ }^{152}$ Bovendien zijn dit ook de geluiden die, een enkele uitzondering daargelaten, in andere Nederlandse, Europese en Amerikaanse steden veel aandacht krijgen (Bijsterveld, 2003; Birkefeld \& Jung, 1994; Smilor, 1977).

\footnotetext{
152 Deze vergelijking is gebaseerd op 70 artikelen uit het Algemeen Handelsblad (waarvan 36 over het geluid in Amsterdam en 34 over stadsgeluid in het algemeen), 104 artikelen uit Het Vaderland (waarvan 10 over Amsterdam en 94 over Den Haag en stadsgeluid in het algemeen) en 109 klachtenbrieven uit het archief van het 'Anti-lawaai comité Groningen'. De Groningse brieven zijn uit de periode januari - april 1936 en de krantenartikelen uit de periode 1919-1939.
} 
Kijken we naar de manier waarop aan deze geluiden in specifiek Amsterdamse artikelen aandacht wordt besteed, dan valt op dat de oordelen over het geluid van venters, straatmuzikanten en carillons het meest uiteen lopen. Sommige auteurs schrijven er lovend over, voor anderen is het lawaai. Alle overige geluiden in het bovenbeschreven rijtje worden in deze teksten enkel genoemd omdat ze ongewenst zijn en dus lawaai. Het geluid van klokken en vliegtuigen wordt, de weinige keren dat het genoemd wordt, in overwegend positieve termen besproken. En het geluid van treinen, industrie en nijverheid komt opvallend weinig aan de orde.

Deze grote variatie aan Amsterdamse opvattingen over geluid en lawaai is geen structuurloze kakofonie maar ook geen uitgewerkte orkestratie. Om enigszins greep te krijgen op de complexe interactie heb ik, met gebruikmaking van de eerder genoemde constructivistische visie op sociale problemen, het geheel van opvattingen en klachten over geluid in een aantal clusters van bij elkaar horende meningen, motieven en interventies onderverdeeld. Tussen deze clusters kunnen weliswaar geen scherpe scheidingslijnen worden getrokken omdat ze elkaar onderling beïnvloeden en soms overlappen, maar er zijn wel zwaartepunten aanwijsbaar. Zo kan er onderscheid worden gemaakt in een cluster over het geluid van venters en straatmuzikanten, een cluster dat zich richt op autogetoeter en verkeersveiligheid, een cluster rondom geluid in woonwijken met de nadruk op de radio en een cluster over stadsgeluid en lawaai als onderwerp voor onderzoek en interventie.

De context waarin deze clusters tot ontwikkeling komen en interacteren is een Amsterdam dat, zoals we eerder gezien hebben, gedurende het interbellum te maken krijgt met een forse groei van het snel- en het fietsverkeer. Tot de crisis in de jaren dertig is er sprake van een stijgende welvaart voor een groeiend deel van de bevolking, waardoor de meerderheid zich een radio en fiets kan veroorloven en de groep autobezitters flink toeneemt. Tenslotte groeit de stad in deze periode ook qua bevolking en oppervlakte en bovendien verruilt een grote groep Amsterdammers hun woning in de overbevolkte en soms verkrotte delen van de binnenstad voor een nieuwe en ruimere woning in rustige woonwijken.

Klachten over het geluid van venters en straatmuzikanten, het eerste cluster, zijn niet specifiek voor het interbellum. Al vanaf het einde van de negentiende eeuw stelt de Amsterdamse overheid allerlei regels op om het aantal venters en straatmuzikanten en de plaatsen waar zij zich mogen ophouden onder controle te kunnen houden. De klachten over het geluid staan niet op zichzelf maar hangen samen met klachten over het hinderen van het verkeer en met commerciële motieven van winkeliers en bedrijven. Winkeliers vinden dat ze oneerlijke concurrentie ondervinden van de venters en ze zijn het met de bedrijven eens dat hun lawaai en dat van straatmuzikanten de klanten wegjagen en werknemers storen (Dijk, 1981; Huberts, 1940). Ondanks het feit dat het geluid van venters en straatmuzikanten ook door tijdgenoten beschouwd wordt als karakteristiek voor de stad, winnen de winkeliers en bedrijven het pleit mede doordat aan hun klachten het argument wordt toegevoegd dat venters verkeershinder 
veroorzaken (Huberts, 1940, pp. 21-23). En zoals eerder al bij de beschrijving van het geluid van het verkeer aan de orde is gekomen, weegt verkeershinder zwaar in deze periode. Met als gevolg steeds minder plekken waar venters en straatmuzikanten zich in de stad mogen ophouden en bovendien voor beide groepen de instelling van een uitstervingsbeleid.

Verkeersproblemen in de stad spelen ook een grote rol bij de discussies rondom het lawaai van autohoorn en claxons, het tweede cluster van bij elkaar horende meningen, motieven en interventies. We hebben eerder al gezien hoe veranderingen in aard en aantal voertuigen en in bestrating leiden tot vraagstukken en discussies over het delen van de straat, veiligheid en waarschuwingssignalen. De Amsterdamse politie bijvoorbeeld tracht via voorschriften maar ook via allerlei activiteiten, zoals artikelen in kranten en een 'stiltebrigade' in 1937, de verkeersdeelnemers te informeren en disciplineren.

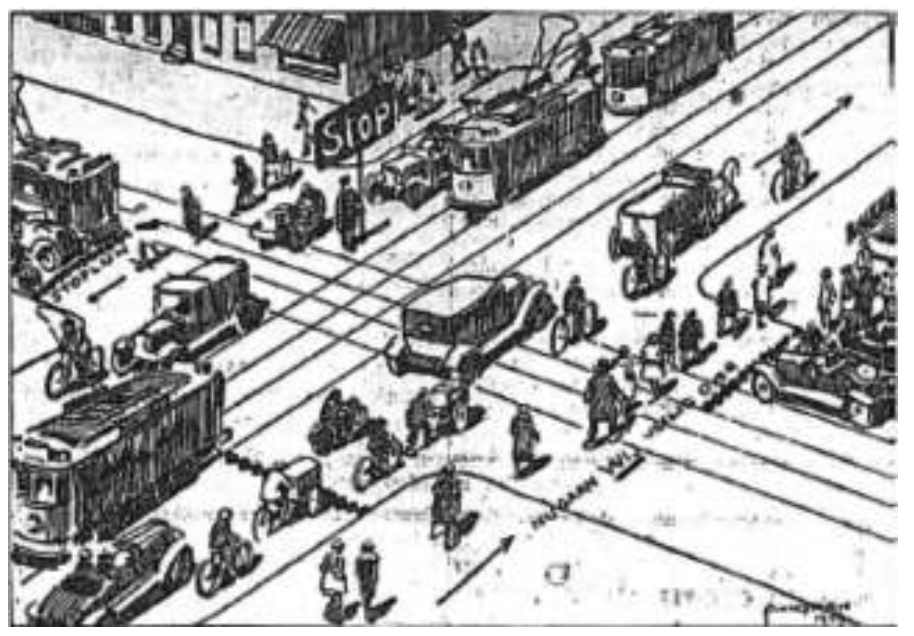

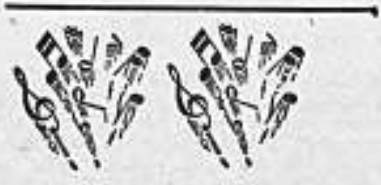

Auto-Muziek!

$U$ vidt $U_{w}$ eloson misstios aro muriteat osh wimphonle solikt Woet $U$, dat niet lederoen er xso over dankit? Dat anderen Us autoheon wearal is nochts liaver niel booren? Wh $U$ en ook eara on denkan dat orue mastachapol wil nood a heoit? MEER STILTE
En wat reeds in zoo legio ingezonden stukken tot uiting kwam, worde dan hier nòg eens herhaald: ook betere discipline van de fietsers en voetgangers en karrevoerders is onmisbaar, wil men komen tot een rustiger en stiller verkeerswezen. Daar zonder zal een zeer groot contingent geluidssignalen $\mathrm{o} \mathrm{nm} \mathrm{i} \mathrm{s}$ b a a $\mathrm{r}$ blijven, die achterwege konden worden gelaten, als alle fietsers en voetgangers en handkarren-duwers zich wat beter aan de verkeersregels stoorden.

Afbeelding 12: Voorbeelden van campagnes en artikelen ter verbetering van het gedrag in het verkeer (Algemeen Handelsblad, 26-10-1925 en 19-07-1934; Het Vaderland, 30-09-1933) 
Voorgaande krantenknipsels zijn illustratief voor deze aansporingen tot beter gedrag door de Amsterdamse verkeerspolitie en door landelijke organisaties als de A.N.W.B. ${ }^{153}$ De tekening geeft aan op welk deel van de openbare weg zich de verschillende soorten verkeersdeelnemers mogen bevinden. Voor ons inmiddels vanzelfsprekend, maar in die tijd nog lang geen ingesleten gewoonte. Het tekstfragment uit een artikel over het verkeer in Amsterdam wijst fietsers, voetgangers en voerders van handkarren (veelal venters) op hun verantwoordelijkheid ten aanzien van een veiliger en stiller Amsterdam. En de advertentie van de ANWB tenslotte, roept autobestuurders op het gebruik van de autoclaxon te beperken.

De advertentie van de ANWB laat ook zien dat alle Amsterdamse discussies en interventies rondom autogetoeter en verkeersveiligheid niet op zich zelf staan, maar onderdeel uitmaken van een groter netwerk van opinies, belangen en activiteiten. Om te beginnen is er de individuele stadsbewoner die zijn ongenoegen over het verkeer in Amsterdam, het autolawaai of het feit dat hij zich als autobezitter gedwongen voelt om te toeteren, kenbaar maakt via brieven aan of artikelen in de krant. Tegelijkertijd wordt diezelfde stadsbewoner door de kranten geïnformeerd over dezelfde problematiek in andere steden en doen buitenlanders die naar Amsterdam komen hun zegje over wat ze in de Amsterdamse straten horen en zien. ${ }^{154}$

Een ander deel van dit 'netwerk' is de Amsterdamse overheid die de eerdere geschetste acties onderneemt om de Amsterdamse bevolking te instrueren en de verkeerssituatie te verbeteren, maar uiteraard ook 'gevoed' wordt door de opinies en klachten van deze bevolking. Dan zijn er ook nog nationale organisatie zoals de A.N.W.B. en de K.N.A.C. (Koninklijke Nederlandsche Automobiel Club) die acties ondernemen op het gebied van autolawaai en veiligheid en contacten onderhouden met (gemeentelijke) overheden. ${ }^{155}$ De laatstgenoemde acties worden overigens niet alleen gevoerd ter verbetering van de verkeersveiligheid en het terugdringen van het lawaai, maar ook om zich als organisatie te profileren en bovendien, wat de K.N.A.C betreft, om de belangen van de autobezitters te waarborgen. Om die reden zorgt deze organisatie ook voor financiële ondersteuning van de Nederlandse Geluidstichting (Bijsterveld, 2008, pp. 127-130). Het cluster rondom autolawaai en verkeersveiligheid omvat dus veel verschillende soorten actoren, van individuele stadsbewoners tot landelijke organisaties, met elk een eigen mix aan motieven en visies op oorzaak en oplossing van dit vraagstuk. Oplossingen die variëren van het opvoeden van de ver-

\footnotetext{
153 'Verkeers-Offensief', Algemeen Handelsblad, 26-10-1925, Avond, p. 2; 'De strijd tegen het lawaai: vragen van verkeer', Algemeen Handelsblad, 19-07-1934, Avond, p.12; Het Vaderland, 30-09-1933, Avond, p.14.

${ }^{154}$ Krantenartikelen over andere steden: Algemeen Handelsblad, 18-08-1927, 13-08-1928, 31-10-1930, 0810-1931, 20-11-1931, 03-11-1932, 22-01-1934, 06-09-1934, 04-10-1934, 24-11-1934, 25-12-1934, 01-091935, 27-09-1935; De Telegraaf, 19-11-1931,16-10-1933; Het Volk, 25-01-1933, 27-01-1933. Artikelen over de ervaringen van buitenlandse bezoekers: Algemeen Handelsblad, 10-01-1929, 09-07-1939; De Telegraaf, 21-06-1933.

${ }^{155}$ Artikelen over ANWB en KNAC: Algemeen Handelsblad, 06-10-1934, 09-11-1934, 15-11-1934, 24-10-1935.
} 
keersdeelnemers en het dragen van oordoppen tot het aanpassen van verkeersregels en voorschriften waaraan voertuigen moeten voldoen.

Met het noemen van de Nederlandse Geluidstichting zijn we ook aanbeland bij het cluster van stadsgeluid en lawaai als onderwerp voor onderzoek en interventie door 'professionals'. De Stichting wordt in 1934 opgericht om in "Nederland een centraal punt tot stand te brengen voor de behandeling van geluidsvraagstukken in den ruimsten zin van het woord en de verspreiding van de kennis daaromtrent." ${ }^{156}$ Als belangrijkste oorzaak van de geluidsvraagstukken noemt de Stichting: "den toenemenden bouw van groote woningcomplexen en het toenemend gebruik van voorwerpen, die hinderlijk geluid veroorzaken, zoowel binnenshuis als buitenshuis." Volgens de Stichting is onderzoek naar de meting van geluid en naar de akoestische eigenschappen van bouwmaterialen en van ruimtes, van groot belang, maar "de bestrijding van het geraas in steden" evenzeer.

Men zal moeten vaststellen in welke maat en hoe de sterkte van het gedruisch kan worden uitgedrukt en moeten bepalen wanneer het hinderlijk wordt. Wellicht zal men kunnen komen tot normen voor toelaatbare gedruischsterkte in een woonwijk, een industrieele wijk, een gemengde wijk. Wellicht kan men komen tot een rationeele lawaaibestrijdingsmethode (Het Vaderland, 01-08-1934).

De Geluidstichting zoekt de oplossing voor de geluidsvraagstukken vooral in meetmethoden, bouwvoorschriften en stedenbouwkundige maatregelen die gebaseerd zijn op de expertise van de Stichting, die voor een belangrijk deel door ingenieurs wordt bevolkt (Bijsterveld, 2008, pp. 124-125). Deze visie komt niet alleen voort uit de behoefte aan broodwinning maar past ook binnen een in die tijd internationaal gedragen geloof in technologie als motor voor sociale en culturele vooruitgang, de zogenaamde technocratische bewegingen (Schot, 2003, p. 266).

Vanuit Amsterdam is vooral M.E.H. Tjaden, directeur van de Dienst Bouw- en Woningtoezicht sinds 1920, actief in de Geluidstichting en onder zijn voorzitterschap wordt in 1936 de Amsterdamse commissie opgericht. Al in 1929 publiceert Tjaden in het vakblad Bouwbedrijf een artikel over de hinder van kleine elektromotoren die blijkbaar tot zoveel klachten leidt dat de Amsterdamse gemeenteraad als eerste in Nederland overgaat tot het instellen van een speciale verordening (Tjaden, 1929). Desondanks besteed ook Tjaden in zijn speech ter gelegenheid van de oprichting van de Amsterdamse commissie relatief weinig aandacht aan het geluid van industrie en nijverheid. Hij wijst het verkeer te land, te water en in de lucht aan als de belangrijkste bronnen van lawaai en ook in zijn uitgebreide opsomming van 'andere' oorzaken worden er nogal wat geluiden uit het gangbare rijtje genoemd: "venten, straatmuziek, hoornmisbruik, fabriekssirenes, locomotieffluiten, knarsen van tramrails, signalen

\footnotetext{
${ }^{156}$ Het Vaderland, 01-08-1934.
} 
rijdende brandweer, stempelmachine postkantoor in woonflat, electrische transformator in woonblok, rijden van vrachtwagens met niet goed vastgesjorde lading, motorbooten, burenhinder met radio en nachtelijke muziek."157

Een vergelijkbare opsomming van hinderlijke geluiden kenmerkt het cluster rondom geluid in woonwijken. Zieken en zwakken, waaronder de vermoeide werkers die moeten bijkomen van hun dagelijkse arbeid en degenen die studeren of in ieder geval 'met hun hoofd moeten werken' worden aangewezen als de slachtoffers van deze geluiden. Zoals onderstaand citaat illustreert, kunnen alle soorten geluid hier als hinderlijk worden aangeduid, zeker in de nachtelijke uren, maar de radio wordt aangewezen als de grootste boosdoener.

En tenslotte: een "Deftige Straat" beteekent nog allerminst rust in de huizen! Als men eens wetenschappelijk kon nagaan, door welke geluiden onze gemoedsrust en ons geestelijk evenwicht het meest worden belaagd, dan maken wij ons sterk, dat dit niet is het verwarde, en daardoor langs-ons-heen-gaande, gedruisch van het groote-stadsverkeer overdag, maar de op zichzelf staande en daardoor des te indringender geluiden, welke 's ochtends vroeg en in de avonduren, welke wij voor rust, afleiding, of geconcentreerden hoofd-arbeid behoeven, tot onze woningen doordringen vooral in het lauwe zomergetij! (...) Daarbij denken wij aan het bijzonder irriteerende geluid van matjes- en kleeden-kloppen; aan het obsedeerende klagen van een hond of kat, die door de buren 's nachts in hun tuin is buitengesloten; maar bovenal aan den meest opdringerigen en onbeschaamden lawaaimaker van den modernen tijd: de radio ('De strijd tegen het lawaai', Algemeen Handelsblad, 19-07-1934).

Bij deze klachten worden de nadelige invloed van het geluid op het zenuwgestel en de algemene overprikkeling van de mens in de alsmaar groeiende en drukker wordende stad vaak aangevoerd als argument. ${ }^{158}$ Anderzijds staat ook vast dat in de loop van het interbellum het aantal bewoners per woning blijft dalen. ${ }^{159}$ Een substantieel gedeelte van de Amsterdamse huishoudens dat over een radio en/of grammofoon beschikt, zal deel uitmaken van de groep die naar de nieuwe woonwijken rondom de oude stad verhuist. Daar komt men in ruimere woningen terecht die bovendien door minder personen worden bewoond. Ook de wijk zelf is veel stiller, omdat men niet langer boven of naast bedrijfjes woont zoals in de gemengde wijken in de oude stad. In lijn met de eerder geciteerde opmerking van Presser over de snelle verschuiving in de

\footnotetext{
${ }^{157}$ Algemeen Handelsblad, 05-05-1936.

${ }^{158}$ Hoewel de overprikkeling van de zenuwen door geluid vaak wordt aangevoerd in klachten, zijn er tegelijkertijd stemmen die beweren dat de klager last heeft van geluid omdat hij of zij een nerveus mens is (Radkau, 1998, p. 109). Deze tegenstelling komt aan het einde van dit hoofdstuk nogmaals aan de orde.

${ }^{159}$ De gemiddelde woningbezetting daalt in Amsterdam van 4,55 personen per woning in 1918 naar 3,65 personen in 1939 (Ottens, 1975, p. 146).
} 
eisen die aan het wooncomfort worden gesteld, lijkt dan ook de conclusie gerechtvaardigd dat niet de toename van lawaai in de stad maar juist de gewenning aan rust en stilte in en om de woning er voor zorgt dat steeds meer bewoners last krijgen van het geluid van de radio, de muziek van de buren, de roep van een venter of het onverwachte getoeter van een auto.

De betogen over de negatieve invloed van geluiden op de menselijke geest gaan vaak gepaard met kritische kanttekeningen bij de kwaliteit van het leven in de moderne tijd en in de grote stad. Deze kanttekeningen blijken niet zozeer samen te hangen met de voortgaande technologisering van samenleving en industrie op zichzelf, want deze werd vanaf het eind van de negentiende eeuw in Europa en ook in Nederland door liberalen, socialisten, confessionele partijen en vakbonden in gelijke mate omarmd (Lente, 1998, pp. 191-196; Schot, 2003, pp. 262-263). Wel is het zo dat de "Bildungselite", de Europese intellectuelen van die tijd, zich door de opkomende industrialisatie en groeiende welvaart aan het einde van de negentiende eeuw bedreigd ziet in haar leidende positie in politiek en maatschappij. Dat leidt tot een kritische houding tegenover de moderne samenleving en ongerustheid over de teloorgang van de cultuur. "Voor het eerst voelt het Bildungsbürgertum zich bedreigd door het Wirtschaftbürgertum, waarboven het zich zo lang - en met zoveel vanzelfsprekendheid - verheven achtte. Er staat dan ook veel op het spel: het (morele) leiderschap over de samenleving." Men vreest dat op cultureel vlak het gebrek aan smaak van de "ungebildete' massa de overhand zal krijgen en leiden tot materialisme en vulgariteit (Braeckman, Bauer, \& De Visscher, 2001, pp. 10-12). Bovendien zien we deze ideeën over de teloorgang van de cultuur ook weerspiegeld in de overwegend negatieve benadering van de stad door romanschrijvers, dichters en cultuurfilosofen (Lees, 1985, p. 308). "De vermenigvuldiging van de prikkeling der zinnen in de straten van de stad waren evenzovele risico's, zoals het opgroeien van stuurloze jeugd en een sterke verbreiding van zedeloos gedrag in het algemeen en criminaliteit in het bijzonder." (Rooy, 2007a, p. 129).

Tegen de achtergrond van het voorgaande is het te begrijpen waarom de radio als geluidsbron zoveel negatieve aandacht krijgt gedurende het interbellum. Vanaf het begin van de jaren twintig verovert dit apparaat de huiskamers in hoog tempo en is daardoor een aansprekend 'bewijs' van het consumentisme van de massa. Bovendien kan die 'massa' gemakkelijk beticht worden van het luisteren zonder enige vorm van onderscheid, want zij mist het daarvoor noodzakelijke ontwikkelingsniveau en wordt tegelijkertijd nog verder afgestompt door de technologie die ze zo kritiekloos omarmt.

The abandonment of the responsibility of choosing sounds carefully was often said to be both symptom and cause of a distracted mind. This distraction was a classed and a gendered phenomenon, a state of being that was understood to be both plebeian and feminine, but also to be technologically induced and hence becoming more common (D. Goodman, 2010, p. 18). 
Daar komt nog bij dat het alsmaar laten spelen van "den meest opdringerigen en onbeschaamden lawaaimaker van den modernen tijd" de rust verstoort die nodig is voor de "geconcentreerden hoofd-arbeid" van de ontwikkelde mens. ${ }^{160}$ Uiteraard is de vraag gerechtvaardigd of deze opvattingen van de "Bildungselite" wel gedeeld worden door de goed geschoolde arbeiders en leden van de burgerij die de teksten over geluid en lawaai schreven die in dit onderzoek zijn gebruikt. Op basis van het sociologisch onderzoek dat Henri Heertje in 1936 uitvoerde onder de Amsterdamse diamantbewerkers, mag geconcludeerd worden dat dit in ieder geval in beperkte mate het geval was. Heertje beschrijft hoe de diamantbewerkers qua huisvesting, gezinsgrootte en ontwikkeling in de voetsporen traden van de Amsterdamse bourgeoisie (Heertje, 1936, pp. 219-304). Verder schrijft hij, naar aanleiding van de constatering dat in tegenstelling tot crisisperiodes in de negentiende eeuw, nu in de jaren dertig, het drankgebruik onder de werkloze arbeiders niet is gestegen: "De goede behuizing tegenover vroeger, en de betere besteding van den vrije tijd, door de ontwikkeling, die diamantbewerkers (en andere arbeiders) hebben verworven, zijn hiervan de oorzaak. De arbeiders lezen nu een dagblad, hebben belangstelling voor sport, luisteren naar de radio en bezoeken ontspanningslokalen voor werkeloozen" (Heertje, 1936, p. 238). Het is dus waarschijnlijk dat het geschoolde en briefschrijvende deel van de arbeidersbevolking, net als de bourgeoisie, via de verworven ontwikkeling tot op zekere hoogte ook de "Bildungsidealen" en het cultuurpessimisme van de intellectuele elite heeft overgenomen om daarmee vervolgens zijn 'minder ontwikkelde' buurtbewoners de maat te nemen en zijn beklag te doen over het moderne leven in de stad.

Rubberzolen, rubberbanden, rubberbestratingen, geruischlooze auto's - alle vindingen van dezen tijd, die de strekking hebben, het lawaai op straat te dempen. Doch het verkeer zelf neemt tien- en honderdvoudig toe, wordt massaler en sneller, en elk modern voertuig heeft een instrument, dat geluid maakt, en deze geluiden, elk op zich zelf en alle te zamen en in verbinding met andere, maken het hart van een groote stad tegenwoordig tot een pandemonium en tasten de zenuwen van den mensch aan.

Inderdaad kan men thans waarnemen, dat in alle groote steden van /Europa - en niet van Europa alleen - een soort verzet van den gewonen burger rijst tegen het lawaai van de straat, dat hem het genoegen van het leven, dat in de groote stad toch al zeer twijfelachtig is, in ieder geval de rust, waarnaar hij na zijn dagelijkschen arbeid haakt, beneemt ('Minder straatlawaai!' Algemeen Handelsblad, 1308-1928).

160 'De strijd tegen het lawaai', Algemeen Handelsblad, 19-07-1934. 
In deze klacht van "den gewonen burger" zien we veel elementen terug die ook in de beschrijving van de andere clusters ter sprake zijn gekomen. De toenemende verkeersdrukte, de moderne snelle voertuigen, het vele claxonneren, de kwalijke invloed van stadsgeluid op het menselijk zenuwgestel en het twijfelachtige moderne leven in de grote stad. Maar de groepering in clusters maakt ook duidelijk hoe de visies op de oorzaak en oplossing van problemen uiteenlopen en samenhangen met verschillende motieven.

Bovendien zijn er ook nog stemmen die al dat klagen over het stadsgeluid maar overdreven vinden. Tegenover de bewering dat het lawaai een verstorende (degeneratieve) invloed heeft op de zenuwen, schilderen zij de klagers af als overgevoelige (gedegenereerde) individuen (Radkau, 1998, pp. 208-211). In onderstaand betoog uit de Amsterdamse Gemeenteraad wordt zelfs de hele discussie over de kwalijke invloed van geluid op de zenuwen naar het rijk der fabelen verwezen.

Vijftien jaar geleden werd een voorstel behandeld, om den honden het blaffen te verbieden; het voorstel om hanengekraai strafbaar te stellen, kon geen meerderheid krijgen. Daarna is gevraagd om pianomuziek te verbieden, vervolgens kwamen de klachten over de gramofoons en eindelijk begint men thans over de radio. Men heeft zelfs gemotiveerd, de uitzendingen na 11 uur te verbieden, omdat de menschen dan naar bed moeten. Spreker woont in een gedeelte der stad, waar veel auto's rijden, die bij het passeeren van dwarsstraten luide signalen geven en hij denkt er over een verzoek in te dienen, om te verbieden, dat die auto's na elf uur geluid geven. De menschen, die wonen aan straten, waar tramlijnen doorheen loopen, zouden kunnen vragen den trams pantoffels aan te doen, opdat zij niet zullen worden gestoord in hun slaap. In een groote stad heeft men nu eenmaal velerlei verschillende geluiden en rumoer. Is daardoor het publiek in een groote stad zenuwachtiger dan op het platteland? Volgens de statistiek, den eenigen maatstaf, dien spreker in dit opzicht heeft, is het percentage krankzinnigen op het platteland grooter dan in de steden (Gemeenteblad 1929, II, p. 2750).

Tenslotte maakt onderstaande spotprent naar aanleiding van een bericht in het Algemeen Handelsblad op 12 mei 1923 over het oprichten van een vereniging tot rumoerbestrijding ook duidelijk dat de bestrijders van stadslawaai lang niet altijd serieus worden genomen. De prent toont een ontwerp voor het wapen van de genoemde vereniging. We zien een zuur kijkend persoon met slaapmuts en nachtkaars die ondanks zijn forse oordoppen met de vinger op de lippen tot stilte maant. Op het schild dat hij voor zich houdt, bungelen een aantal geluidsbronnen aan de galg. Het geheel lijkt te willen suggereren dat het hier om een stelletje zuurpruimen gaat die met een kanon op een mug willen schieten. 


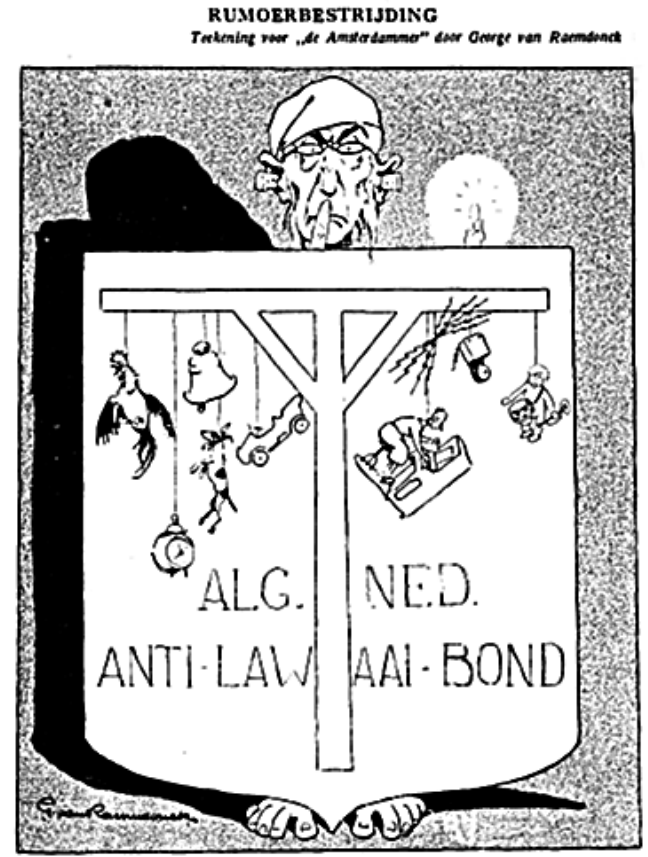

Ontwep roor ene shild val den A. N. A. L. B.
Afbeelding 13: "Rumoerbestrijding" (George van Raemdonck).

\section{Conclusie}

Afgaande op het aantal artikelen en ingezonden brieven in de kranten, de oprichting van de Amsterdamse commissie van de Geluidstichting in 1936 en enkele discussies in de gemeenteraad, is stadsgeluid en vooral stadslawaai in Amsterdam een onderwerp waarover men tijdens het interbellum meer schrijft en klaagt dan in de voorgaande vijftig jaar. Amsterdam wijkt daarin niet af van andere Europese en Amerikaanse steden. We kunnen de opkomst van dit debat over stadsgeluid in Amsterdam echter niet rechtstreeks toeschrijven aan de toename van het aantal geluidsbronnen als gevolg van industrialisering en groei van de stad, zoals in publicaties over Duitse steden wordt gedaan (Birkefeld \& Jung, 1994; Saul, 1996a). De voorgaande analyse van de Amsterdamse teksten vanuit het perspectief van de politiek van geluid laat zien dat het debat daarvoor te complex is en te gevarieerd qua meningen, motieven en interventies of pogingen daartoe. Bovendien blijkt uit de analyse van 'ecologie van geluid' dat er ook allerlei geluiden zijn, zoals van industrie, nijverheid en treinverkeer, die zeker niet in aantal afnemen maar desondanks nauwelijks genoemd worden in teksten en discussies.

In de toename van klachten over stadsgeluid in Amsterdam horen we dan ook niet zozeer de weerklank van meer geluid, maar van cultuurpessimisme en zorgen over het 
moderne leven in de grote stad. De onmiskenbare toename van het verkeer vraagt om aanpassing van het gedrag op straat en leidt tot fundamentele en omstreden veranderingen in het gebruik van deze publieke ruimte. Dankzij de opgaande lijn in de sociaal economische situatie van een groot deel van de stadsbevolking, gaat onderwijs en ontwikkeling vanaf het einde van de negentiende eeuw een grotere rol spelen. Het gedachtengoed van de "Bildungselite" sijpelt zo door naar de middenklasse en naar geschoolde arbeiders. Tegelijkertijd zorgt de internationale economische crisis in het interbellum voor veel onzekerheid en creëert zo een goede voedingsbodem voor dat cultuurpessimisme. Nu velen gewend zijn geraakt aan stilte in de woning, leidt de alom aanwezige radio gemakkelijk tot doemdenken en klachten. Het voortdurend laten tetteren van de radio is in de ogen van tijdgenoten een duidelijk teken van het gebrek aan onderscheidingsvermogen en de vulgariteit van de 'massa mens'. Tenslotte geven alle klachten over geluid tezamen professionals de mogelijkheid om hun expertise aan te bieden voor "de bestrijding van het geraas in steden" en het ontwikkelen van "een rationeele lawaaibestrijdingsmethode."161

\footnotetext{
${ }^{161}$ Het Vaderland, 01-08-1934.
} 



\section{Blaffen en loeien: stadsgeluid in oorlogstijd}

\section{Inleiding}

Bijna ieder oorlogsdagboek begint hetzelfde. In de vroege ochtend van 10 mei 1940 wordt de dagboekschrijver gewekt; door explosies, door overkomende vliegtuigen of door verschrikte familieleden. Hij gaat in pyjama de straat op, praat met de buren, oppert nog even dat het een militaire oefening is, maar realiseert zich dan wat er gebeurt: Nederland is in oorlog (Boom, 2003, p. 17).

Vrij abrupt blijken knallende explosieven niet langer te verwijzen naar een oefening in weerbaarheid gericht op vrede en veiligheid. Zonder dat er ook maar iets verandert aan het geluid van de explosies en overkomende vliegtuigen, maakt het besef dat het niet om een militaire oefening gaat een wereld van verschil. Nederland is in oorlog. Het geknal betekent nu wat anders en er wordt niet meer op dezelfde manier naar geluisterd. Deze situatie is te vergelijken met het verhuizen naar een andere locatie. Direct na de verhuizing zijn alle geluiden die gehoord worden nieuw en dringen ze zich ook veel meer op. In die toestand bevinden zich ook de inwoners van Amsterdam bij het uitbreken van de oorlog. Qua geluid lijkt het alsof de hele stad naar een hele nieuwe plek verhuist.

De verandering in het klanklandschap van de stad speelt zich af op meerdere niveaus. In de eerste plaats krijgt de stad te maken met het geluid van oorlogshandelingen en ten tweede beïnvloedt de oorlog het dagelijkse leven en daardoor het dagelijkse geluid. Naast deze veranderingen in de bronnen van geluid kan ook betekenis van bepaalde geluiden ingrijpend wijzigen. Denk maar aan het eerder genoemde geluid van explosies dat niet langer staat voor een geruststellende militaire oefening maar voor een aanval door een vijandige mogendheid.

In dit hoofdstuk over het geluid in Amsterdam tijdens de Tweede Wereldoorlog komen alle perspectieven aan bod. We 'luisteren' naar oorlogsgeluiden en veranderende stadsgeluiden (ecologie) en staan stil bij het gebruik van geluid als uiting van verzet (politiek). De semiotiek van geluid komt echter nadrukkelijker in beeld omdat, zoals eerder gezegd, het uitbreken van de oorlog niet alleen zorgt voor nieuwe geluiden maar ook voor ingrijpende wijzigingen in hun betekenissen.

Geluid lijkt een belangrijke rol te spelen in oorlogservaringen. In doorsnee oorlogsfilms vliegt de actie de kijker bijna letterlijk om de oren. Geluid en oorlogservaring zijn bovendien nauw verbonden in autobiografische werken over het leven in de loop- 
graven tijdens de Eerste Wereldoorlog. ${ }^{162}$ En in haar proefschrift wijst Carolyn Birdsall op het belang van geluid bij het navigeren door het verduisterde en zwaar onder vuur liggende Düsseldorf gedurende de Tweede Wereldoorlog (Birdsall, 2010). Toch is, voor zover mij bekend, buiten het werk van Birdsall geen onderzoek gedaan naar oorlogsgeluid in de stad en/of stadsgeluid in oorlogstijd. ${ }^{163}$ In Birdsalls proefschrift over de culturele betekenis van het fenomeen geluid en het gebruik van geluidstechnologieën gedurende het nazitijdperk ligt de nadruk op de politiek van geluid. Ze beschrijft weliswaar de rol van geluid bij het oproepen van oorlogsherinneringen en het navigeren door het bedreigde Düsseldorf, maar haar onderzoek is primair gericht op de successen en mislukkingen van het gebruik van geluidstechnologieën door de nazi's.

In dit hoofdstuk komt de politiek van geluid minder aan bod, de veranderingen in de dagelijkse stadsgeluiden en hun betekenis voor de bewoners des te meer. Bovendien gaat het hier om een stad die bezet is en daardoor met andere bedreigingen te maken heeft dan Düsseldorf. Daarom komen hier de volgende vragen aan bod: Welke rol speelde geluid in de bedreigingen waarmee de Amsterdammers te maken kregen? Hoe werd Amsterdam voor het eerst met oorlogsgeluid geconfronteerd en wat was de reactie van de bewoners? Welke rol speelde oorlogsgeluid na de capitulatie? Hoe veranderde het geluid van de stad en wat betekende dat voor de Amsterdammers?

Alvorens in te gaan op deze vragen wil ik nog even stil staan bij het bronnenmateriaal dat gebruikt is voor dit deel van het onderzoek, om zo een indruk te geven van de personen die straks aan het woord komen. In het tweede hoofdstuk van deze dissertatie is al aangegeven dat dagboeken de belangrijkste bronnen zijn voor teksten over het geluid van Amsterdam tijdens de oorlog en dat dit onderzoek gebaseerd is op een verzameling van 30 dagboeken in het bezit van het Nederlands Instituut voor Oorlogsdocumentatie (NIOD). De geselecteerde dagboeken variëren in omvang van 3 tot meer dan 1700 pagina's. Onder de auteurs bevinden zich 9 vrouwen, 19 mannen en 2 schrijvers van wie het geslacht niet duidelijk is. De leeftijd van de auteurs is ook niet altijd vast te stellen. Zeker is dat 4 schrijvers jonger zijn dan 20 jaar en 5 ouder dan 60 . Relatief veel dagboekschrijvers zijn joods (12), 1 jeugdige auteur is lid van de Jeugd-

\footnotetext{
${ }^{162}$ Bekende voorbeelden van boeken over het leven in de loopgraven zijn E. Remarque, Im Westen nichts Neues (Berlijn 1929) en J.B. Priestley, Margin released. A writer's reminiscences and reflections (Londen 1962).

163 In de bundel Akustisches Gedächtnis und Zweiter Weltkrieg onder redactie van R. Maier staan herinneringen aan de oorlog centraal (Maier, 2011). Augenblicke der Gefahr: Der Krieg und die Sinne van Julia Encke behandelt de rol van en invloed op de zintuigen in levensbedreigende situaties (Encke, 2006). 'Sight, sound, and tactics in the American civil war' van Ross gaat specifiek in op de rol van geluid voor de tactische oorlogsvoering tijdens de burgeroorlog in de V.S. (Ross, 2004). Yaron behandelt de verschuiving in de (symbolische) relatie tussen geluid en de (veronderstelde) kracht van wapens (Yaron, 2011). Sonic warfare van Goodman pleit voor meer aandacht voor de (fysieke) inwerking van geluid (Goodman, 2010). En het hoofdstuk van Goodale over oorlogsgeluid in Sonic persuasion gaat in op het gebruik van geluid in oorlogsreportages en komt daarmee nog het dichtst in de buurt van mijn boek (Goodale, 2011).
} 
storm en 1 schrijver vertrekt als vrijwilliger naar het Oostfront. ${ }^{164}$ De auteurs woonden verspreid over de stad: aan de overkant van het IJ, in de grachtengordel, in het Museumkwartier, de Helmers-, Apollo- en Rivierenbuurt en Watergraafsmeer. Deze schrijvers vormen geen dwarsdoorsnede van de Amsterdamse bevolking, maar ze komen wel uit verschillende lagen van de samenleving en delen van de stad en bovendien behoren ze tot verschillende leeftijdscategorieën.

\section{"Een geweldig onweer en rumoer": Oorlogsgeluid in de stad ${ }^{165}$}

Op de vrijdag voor Pinksteren, in de nacht van 10 mei 1940, begint voor Nederland de Tweede Wereldoorlog. In de loop van die nacht worden veel mensen wakker van het geluid van vliegtuigen en explosies. Ook voor de meeste inwoners van Amsterdam dient de oorlog zich in eerste instantie aan in de vorm van geluid.

Om ongeveer 3 uur wakker door geraas van vliegtuigen en explosies van afweergeschut. Zagen donker gekleurde vliegtuigen overvliegen waarop werd geschoten. Dachten aan aanval op Engeland door de lucht, waarbij onze neutraliteit werd geschonden. Werd weer stil, dus wij weer in slaap. Om 4.30 weer wakker toen niet meer geslapen. We waren in oorlog met Duitschland! (db: van Buuren).

In de daaropvolgende dagen betrekken militairen stellingen in de stad, zijn er her en der schietpartijen en zorgt een verdwaalde bom op de hoek Herengracht en Blauwburgwal voor tientallen dodelijke slachtoffers en gewonden. Vanuit haar slaapkamer ziet de twintiger Mirjam Levie deze bom vallen en inslaan. "Het gieren van die bom was onbeschrijfelijk. Daarna was ik volkomen ondersteboven. Ik kon niet meer eten, zag spierwit, en zat de hele dag te trillen" (Bolle, 2003, p. 19). Toch is het militaire geweld vooral gericht op de haven en Schiphol (Boer \& Duparc, 1948; Meershoek, 2007). Tot de capitulatie blijft de directe ervaring van het oorlogsgeweld voor veel inwoners van Amsterdam dan ook beperkt tot het geluid van vliegtuigen, geschut en de sirenes van het luchtalarm. Dat blijkt ook uit de dagboeken. Als het gaat om de eigen ervaring van oorlogshandelingen vormt het geluid van vliegtuigen, geschut en de sirenes van het luchtalarm tot 15 mei de constante in de Amsterdamse dagboekverslagen.

Men schrijft in deze periode over het 'geraas', 'geronk' of 'gesnor' van vliegtuigen, het 'bulderen', 'daveren' en 'knetteren' van geschut, en het 'loeien' of 'dreunen' van

\footnotetext{
${ }^{164}$ Evenals het beroemde dagboek van Anne Frank, zijn ook de dagboekbrieven van Mirjam Bolle integraal gepubliceerd (Bolle, 2003; Frank \& Frank, 2009). Gedeelten uit de dagboeken van Gerlof Verwey zijn verwerkt in de publicatie 's Levens avontuur: een autobiografie (Verwey, 1994).

165 “Vrijdag 10 Mei 1940. Vannacht om half drie werden wij wakker, door een geweldig onweer en rumoer. Tenminste wij dachten dat het onweer was maar even later vernamen wij, dat het niet zo was, doch dat er zeer veel vliegtuigen in de lucht waren" (db: Koekenheim - Voet).
} 
het luchtalarm. Met deze geluiden wordt men 's nachts maar ook overdag geconfronteerd. Dat zorgt in de eerste plaats voor onrustige nachten. "Onrustige slaap door deze alarms werkt vermoeiend" (db: van Buuren, 13-05-1940) en "Slapen doen we niet door het constante geronk van de vliegmachines" (db: Bruijn-Barends, 13-05-1940). Vreemd genoeg spreekt men daarbij het meeste ongenoegen uit over het luchtalarm. Kanonnen bulderen of daveren en vliegtuigen ronken of razen, maar alleen van de sirene weerklinkt een "akelig geloei" (db: van der Does, 12-05-1940). Ook verbindt men het geluid van vliegtuigen en geschut niet expliciet aan gevaar, terwijl het alarm wel angstig maakt of de zenuwen sloopt (db: Bruijn-Barends, 13-05-1940).

Over zessen ging de eerste sirene. Je dacht, dat je laatste uurtje geslagen had, maar ging toch rustig met je bundeltje over je arm op de trap, waar je toilet ging maken. Na een poos gingen de sirenes weer, maar we herkenden de geluiden niet en bleven zoet zitten. Daar werd de krant in de bus geschoven en we begrepen dat het luchtalarm uit was (db: Lans- Van der Wal, $\pm 12-05-1940)$.

Die schrik voor de sirene lijkt opmerkelijk omdat het alarm enkel waarschuwt voor mogelijk gevaar, terwijl vliegtuigen en geschut natuurlijk wel een potentieel gevaar vormen. Deze situatie verandert overigens vrij snel. Het lijkt er op dat het geluid van vliegtuigen en geschut sterker met gevaar wordt geassocieerd nadat men dit (potentiële) gevaar in de directe omgeving heeft beleefd. Die ervaring is er bij het uitbreken van de oorlog voor velen nog niet. Nederland was immers niet betrokken bij de Eerste Wereldoorlog en bovendien speelden vliegtuigen in die oorlog nog nauwelijks een rol (Chickering, 2007, pp. 98-99). Men ziet zeker het gevaar en tijdens de mobilisatie is er aandacht voor in de media, maar afgaande op een krantenartikel over een voorlichtingsbijeenkomst staat het voorkómen van paniek centraal.

De indruk van den eersten bomaanval is alleen maar verwarring en oorverdovend lawaai. Het resultaat valt echter nog al mee, en als men er aan gewend is kan men zelfs rustig nagaan wat er gebeurt en wat voor schade wordt aangericht. (...) De vliegtuigen vliegen steeds in formatie. Het eskader is dus meestal gemakkelijk van den grond af te volgen; men loopt pas gevaar, als de vliegtuigen zich vrijwel boven ons hoofd bevinden. Men kan ook het best zo lang mogelijk blijven kijken wat er gebeurt ('Hoe men zich beschermt tegen luchtaanvallen en gas', Het Vaderland, 14-03-1940, ochtend, p. 2).

Voor Amsterdammers die zelf niet rechtstreeks betrokken zijn bij de oorlogsvoering zijn de dagen voor de capitulatie vooral gevuld met hunkeren naar informatie over de ontwikkelingen. Op vrijdag, de eerste dag van de oorlog, zijn de beurzen en scholen gesloten en alle openbare vermakelijkheden afgelast (Boer \& Duparc, 1948). Dan volgt het Pinksterweekeinde. Levend tussen hoop en vrees schrijven enkelen over het 
schrille contrast tussen het mooie voorjaarsweer en de angst voor wat komen kan. "Het was niet warm, maar toch zonnig buiten. Jubelende natuur. Groen, ontluikende bloemen, vogelgezang, maar in aller hart beklemming en vrees" ( $d b$ : van der Does, $12-$ 05-1940). De meeste dagboekschrijvers luisteren voortdurend naar de radio, enkelen gaan de stad in op zoek naar berichten over het verloop van de oorlog. Een stroom van geruchten komt op gang en elk kwartier is er nieuws op de radio. Naast het meer incidentele geluid van vliegtuigen, geschut en sirenes, is het dan ook vooral de radio die de inwoners van Amsterdam in contact brengt met de oorlog.

In de stad kon je overal de radio beluisteren, het prettigst in de hal van 'Cineac'. Telkens berichten over vliegtuigen en parachutisten, die in alle mogelijke vermommingen neerkwamen. (...) Verscheidene families besloten om de hele nacht bij de radio te blijven en niet uit de kleren te gaan" ( $d$ b: Lans- van der Wal, 10-051940).

Bij Freddy stond ook de radio aan op sjabbat - de opperrabbijn had dat bevolen en je hoorde maar steeds: 'Post Wijk bij Duurstede' (of een andere plaats natuurlijk) 'gesignaleerd twintig Duitse vliegtuigen, vliegende van Zuid-Oost naar West, enz. enz.' Je voelde de vliegtuigen op je af komen. Ik ging weer naar huis. Er was nu voortdurend luchtalarm. En dan ging een motorbrandspuit, die bij ons voor de deur stond ter bescherming van het laboratorium tegenover ons huis, snorren, zodat je dol werd van het lawaai. De radio sprak van zuiveringen van de NSB, enfin, ik kan nooit beschrijven hoe deze dagen waren (Bolle, 2003, p. 20).

Op dinsdag 14 mei wordt Rotterdam gebombardeerd. Op het eind van de middag wordt bekend dat de legerleiding heeft besloten te capituleren. "De toestand is vreeselijk. $11 \mathrm{x}$ alarm. We kunnen het niet langer uithouden. De Koningin weg, de regering weg. (...) Om 7 uur hoorden we door de Radio dat we ons hebben overgegeven. Generaal Winkelman behoedde ons voor algeheele vernietiging. We zijn zoo diep rampzalig dat we in dof zwijgen voor ons uitstaren" (db: Bruijn-Barends). Elders in de stad is het rumoerig. Eerder op de dag heeft een stroom van voornamelijk joodse vluchtelingen geprobeerd de haven van IJmuiden te bereiken. Tevergeefs, velen komen door de verstopte wegen de stad niet eens uit of bereiken IJmuiden te laat en keren terug naar huis (Bolle, 2003; Hacohen, 1990; Kolfschooten, 2002). Ondanks het mooie weer roken veel schoorstenen omdat men in allerijl papieren en boeken verbrandt, ook op straat.

De capitulatie wordt door velen met gemengde gevoelens ontvangen (Boom, 2003, pp. pp. 18-30). “Nederland heeft gekapituleerd' hörten wir. Die Angst vor neuen Bombardementen wie in Rotterdam war nun vorbei, doch die Sorge vor Schlimmeren dafür da“ (db: Hanemann-Keleman). Op 15 mei, aan het begin van de middag worden Amsterdammers geconfronteerd met Duitse troepen die door de stad trekken. Het is Hitler's wens om de capitulatie demonstratief te bezegelen met een tocht door de 
hoofdstad. De doortocht verloopt zonder incidenten en er zijn niet veel dagboekschrijvers die er bij stil staan. Shmu'el Hacohen, dan 14 jaar oud, bekijkt het binnentrekkende leger vanaf de Berlagebrug: "We kregen een ontzettende macht te zien, die ons voorbijdaverde in een eindeloze stroom" (Hacohen, 1990, p. 157). Vanaf dat moment gaat het voor de inwoners van Amsterdam niet langer om een oorlog die voornamelijk 'gehoord' wordt via de radio of in de vorm van het geluid van vliegtuigen, schieten en luchtalarm.

\section{Stadsgeluid in oorlogstijd}

\section{Verkeer}

$\mathrm{Na}$ de capitulatie worden allerlei alledaagse activiteiten op een andere manier voortgezet en dat heeft ook gevolgen voor het klanklandschap. Het bedrijfsleven komt op 16 mei weer op gang en de meeste scholen gaan op maandag 20 mei weer open, maar het geluid van het verkeer is anders. Omdat er vrijwel geen auto's en bussen meer rijden, is het overdag opvallend stil in de stad. "May 18. (...) Amsterdam is very calm: there is no traffic and no damage and very few Germans about" ( $d b$ : Cox). En een week later schrijft van Buuren: "Warm weer. 's Middags boodschappen doen als gewoonlijk. Vrijwel geen Auto's meer op straat. Alleen vervoer van soldaten en levensmiddelen is nog toegestaan. Stadsbuslijnen òf opgeheven òf ingekrompen. Ook dokters kunnen hun patiënten niet meer per auto bezoeken" (db: van Buuren, 25-05-1940).

Vanaf 9 juli verschijnen er volgens van Buuren weer taxi's op straat. Vanwege de benzineschaarste verdwijnen particuliere auto's blijvend uit het straatbeeld en gaat men ook over op fietstaxi's. "Voor't eerst een Trekfiets in Amsterdamsche straten. Een fiets met 2 persoons bakje er achter, dit in plaats van de taxi's" (db: van Buuren, 12-061940). Medio 1941 echter is het op bevel van de bezetter afgelopen met de fietstaxi. ${ }^{166}$ Ook doen met paarden bespannen rijtuigen dienst als taxi. Naar aanleiding van een bezoek aan het Leidsche Plein Theater "om de zorgen te vergeten" schrijft een auteur: "Toen wij er uit kwamen (...) was het pikdonker onder de bomen op het Leidsche Plein. Met de silhouetten van menschen, paarden en rijtuigen (die nu de taxi's vervangen), de zwakke lichtjes van booglampen, fietsen en trams, biedt het geheel een ouderwetschen aanblik - vorige eeuw of zoo" (db: Verwey, 05-09-1940).

\footnotetext{
${ }^{166}$ De commerciële exploitatie van fietstaxi's wordt verboden omdat deze strijdig zou zijn met "het gezonde en natuurlijke moraliteitsgevoel van den Noordeuropeeschen mensch' (Meershoek, 2007, p. 249).
} 


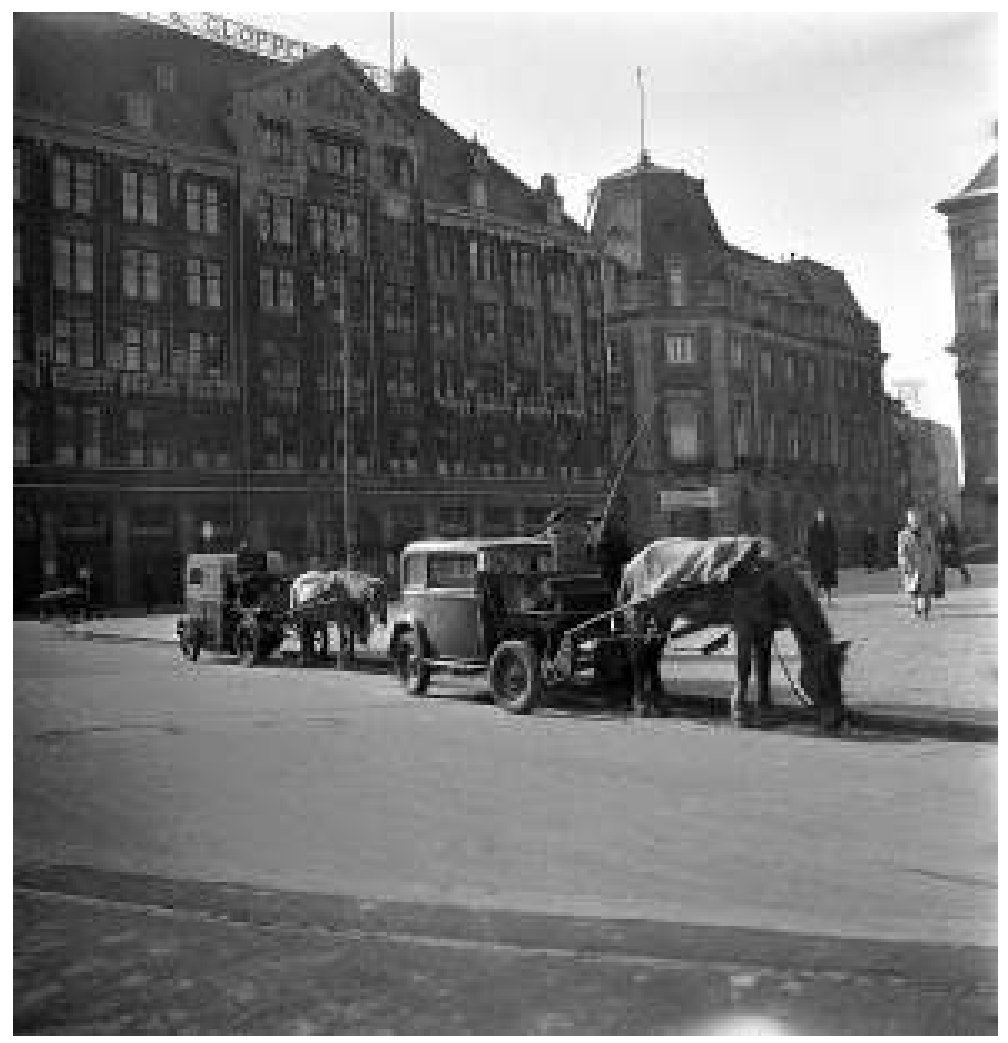

Afbeelding 14: Paardentaxi's op de Dam, 1940-1945 (Ad Windig)

Met paarden bespannen karren vervangen ook het gemotoriseerde vrachtvervoer, naast handkarren en bakfietsen. De terugkeer van het paard in de stad wordt ook opgemerkt in een aantal krantenartikelen, maar met uitzondering van Verwey wordt het door geen van de dagboekschrijvers genoemd. ${ }^{167}$ Het geluid van de paarden komt al helemaal niet aan de orde. Mogelijk omdat paarden vlak voor de oorlog nog een gebruikelijk verschijnsel waren in de stad, ondanks de sterke groei van het gemotoriseerde vrachtverkeer na de eerste wereldoorlog (Buiter, 2005, p. 200).

Omdat het openbaar vervoer vanaf het begin van de oorlog flink wordt teruggebracht, mogen we aannemen dat het fietsverkeer toeneemt. Ruim twee jaar na de capitulatie, op 20 juli 1942 schrijft van Buuren: "Amsterdam was vandaag een andere stad dan eergisteren. Er waren weinig of geen fietsen op straat en het leek vreemd." De dag er voor heeft het gerucht ronde gedaan dat in omliggende steden fietsen op grote schaal in beslag zijn genomen en dat is voor veel mensen een reden om hun fiets

\footnotetext{
167 'Grazende paarden op het asfalt. Zij zwoegen voor zware verhuisauto's', De Telegraaf, 23-05-1940; 'Een verhuisboot in de gracht', Algemeen Handelsblad, 22-05-1940, Persdocumentatie Collectie Stadsarchief Amsterdam' (toegangsnummer 30486, deelonderwerpen 932-984, bladnummer 145875).
} 
in veiligheid te brengen. Een dik half jaar later schrijft Sander: "Het valt meer en meer op hoe weinig menschen zich tusschen 8 en 9 uur naar hun werk in de stad begeven. Wel zijn de trams overvol: de menschen staan met meerdere op de treeplanken (...). De honderden, ja duizenden rijwielen zijn van den weg. Voor zoover ze niet door de Duitsche Weermacht gevorderd zijn, kan men toch niet rijden door gebrek aan banden“ (db: Sander, 04-02-1943).

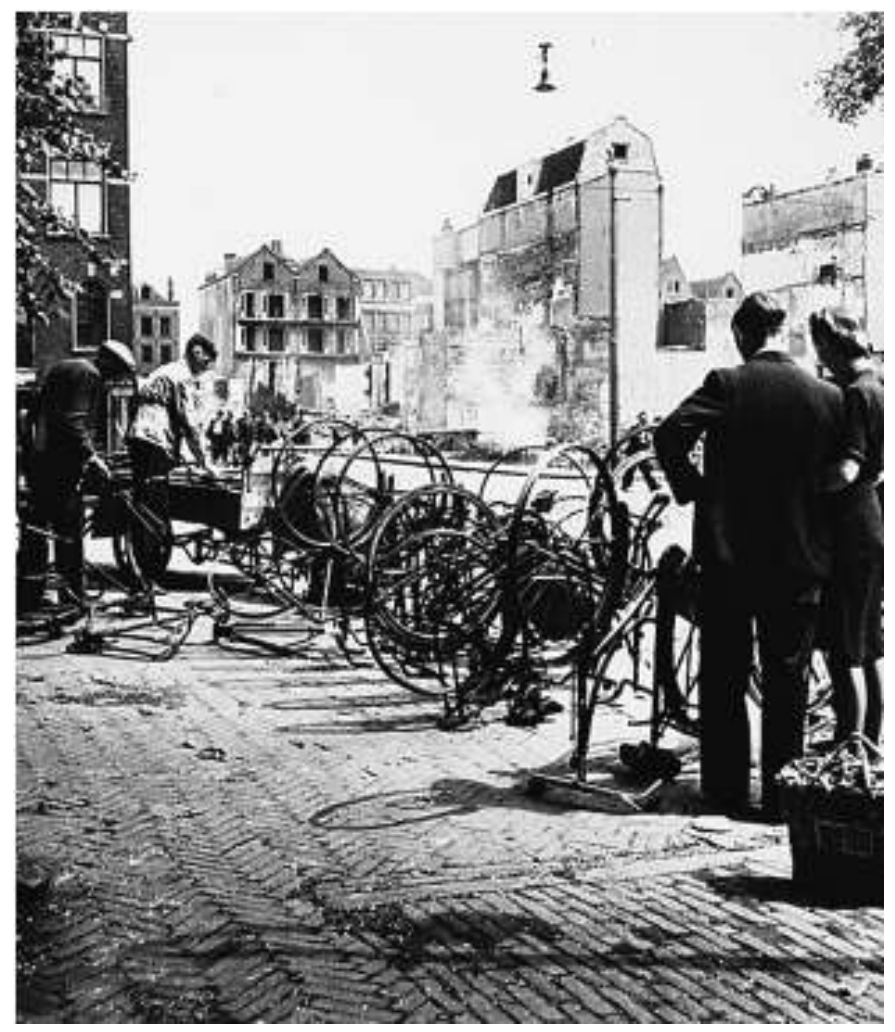

Afbeelding 15: Verkoop van fietsen zonder banden op het Waterlooplein, 1940-1945 (Ad Windig)

Weer anderhalf jaar verder, aan het begin van de Hongerwinter is de situatie weer veranderd: "De stad is kalm, zonder trams, er wordt veel gefietst en de duizenden wachtgelders gebruiken hun vrije tijd met naar of in de richting van Hoorn te fietsen en daar wat eetbaars machtig te worden. Dit gaat door ondanks het voortdurende controleeren en het vorderen van de fietsen" (db: van Donkelaar, 30-10-1944). 
Het lijkt er dus op dat de stad die volgens Cox al op 18 mei 1940 stil was, gaandeweg de oorlog steeds stiller en stiller wordt. Dat wordt niet alleen veroorzaakt door het verdwijnen van gemotoriseerd verkeer en de tram vanwege de groeiende schaarste aan brandstoffen, maar wrang genoeg ook omdat meer en meer mensen worden opgepakt en weggevoerd. Eind juni 1942 schrijft Lans-Van der Wal: "Vroeger trok ik er trouw op uit om groente, nu raakt het me zo weinig, omdat alles zo erg is: afgrijselijk zijn de jodenvervolgingen, maar onze jongens gaan ook allemaal. Het is zo stil op de straten." En nog geen jaar later maakt ook Mirjam Levie de balans op.

Op de Munt is het zo stil dat er geen politie meer staat. Auto's zie je in Amsterdam überhaupt bijna niet meer, alleen weermacht en nog een enkele andere. Fietsen zijn ook verminderd, en door dit alles is het verkeer zo eenvoudig geworden dat er absoluut geen verkeersagent meer voor nodig is. (...) Maar nu de Jodenbuurt, bv. de Breestraat. Die is doodstil, omdat een groot gedeelte van de mensen weggehaald is. (...) Ik wilde je dit even vertellen omdat de stad eruitziet, arm, verlaten, smerig (Bolle, 2003, p. 98).

Het verhaal van een alsmaar stiller wordende stad lijkt in tegenspraak met het feit dat in het begin van de oorlog het aantal 'inwoners' plotseling toeneemt. "Die Deutschen rückten ein, ihre blöden abgehackten Lieder singend. Die Strassen waren abgesperrt, der Verkehr stockte, die Trams waren überfüllt" (db: Hanemann-Keleman, p 1-6). Drie maanden na de capitulatie telt de stad veertienduizend Duitse militairen, later neem dit aantal af (Meershoek, 2007). "In de scholen in onze omgeving Duitsche soldaten ondergebracht. 's Avonds hooren we de signalen" (db: van Buuren, 01-08-1940). Verder rept geen enkel van de gelezen dagboeken over de nabijheid van of contact met Duitse soldaten. ${ }^{168}$ Het lijkt alsof ze niet gehoord en gezien worden, tenzij ze schreeuwen en geweldadig zijn. Daarover later meer.

\section{Straatmuziek}

Volgens de Kroniek van Amsterdam organiseerde de bezetter en haar Nederlandse collaborateurs ( N.S.B, Jeugdstorm) in de periode 1940-1943 een aantal malen een parade, defilé of mars in de stad. In het gebouw van het NIOD is een foto te zien van een dergelijke mars op de Herengracht (waarschijnlijk op 15 februari 1941). Afgaande

\footnotetext{
${ }^{168}$ Andere dagboeken in de NIOD collectie blijken juist wel passages te bevatten over contact met Duitse soldaten. In We leven nog: De stemming in bezet Nederland is daar een hele paragraaf aan gewijd onder de titel "Allemaal nette kerels'. De nieuwe machthebbers' (Boom, 2003, pp. 25-26). Daarbij wordt echter niet verwezen naar een auteur uit Amsterdam, wel naar auteurs uit andere steden (Rotterdam, Den Haag) en het platteland. Een mogelijk verschil tussen stad en platteland speelt hier dus geen rol.
} 
op het kleine aantal personen dat buiten de marcherende groep te zien is, lijkt het er niet op dat dergelijke marsen en parades op veel belangstelling konden rekenen. Dat blijkt ook wel uit de onderzochte dagboeken. Over het algemeen worden dit soort evenementen helemaal niet genoemd. Enkel een oudere dame die een zeer omvangrijk dagboek heeft bijgehouden schrijft onder het krantenknipsel met de kop 'W.A.Marsch te Amsterdam ${ }^{\prime 169}$ dat niemand uit de kennissenkring van de schrijfster is gaan kijken. Verder noemt ze ook nog een bijeenkomst die op 27 juni 1941 werd gehouden op het museumplein: "Vandaag houdt Seys Inquart een groote rede hier op het IJsclub terrein. (...) Troepen trekken door de straten er heen. Dat de Duitschers gaan vinden we nog zoo erg niet, maar dat de Holl. landverraders met hooge borst er heen marcheeren onder een valsch miserabel gezang is wel heel erg en doet je hart bevriezen" (db: Bruijn-Barends, 09-11-1940, 27-06-1941).

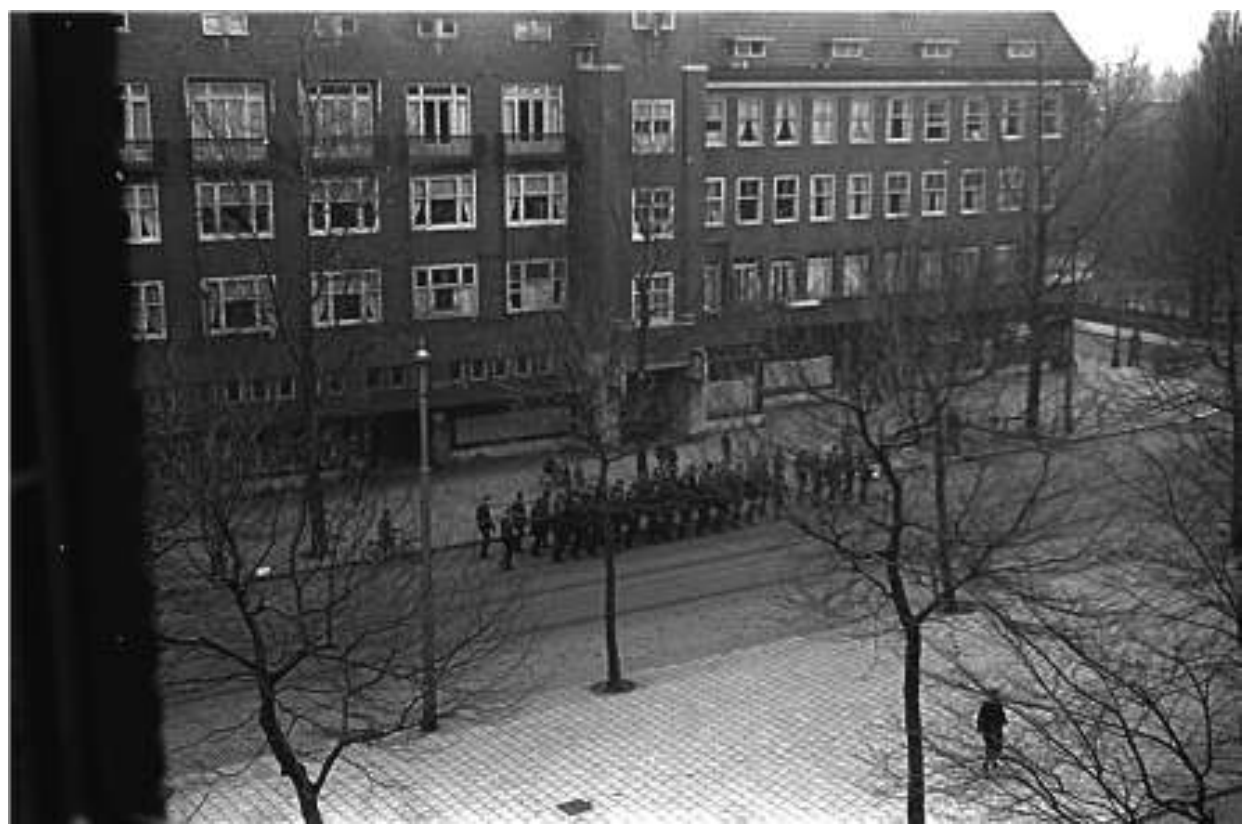

Afbeelding 16: Heimelijk gemaakte opname van een Duitse militaire parade op de vrijwel verlaten Amstelveenseweg, ca 1944 (Jacobus Hofman)

Het oordeel over het zingen van Duitse soldaten en leden van de NSB in termen van 'blöden abgehackten Lieder' en 'valsch miserabel gezang' is een soortgelijke reactie als deze lieden niet willen zien of horen. Het is een typisch voorbeeld van 'de politiek van geluid'. Het geluid staat hier symbool voor een situatie die men verafschuwt maar niet

\footnotetext{
${ }^{169}$ Gehouden op 9 november 1940.
} 
kan veranderen en wordt daarom genegeerd of afgedaan als lelijk of als hinderlijke herrie.

Een ander voorbeeld van de 'politiek van geluid' is de stroom van anti-Duitse liedjes en gedichten die op gang komt, maar ook de maatregelen die de bezetter daartegen neemt. In Het Parool van 16 oktober 1940 staat een stukje over orgeldraaiers:

Het Deutschtum en de orgeldraaier - Een zestal Amsterdamsche orgeldraaiers worden sinds begin Augustus in een Duitse gevangenis vastgehouden, omdat zij op straat nationale liederen met hun pierement ten gehoore hebben gebracht. Das teutsche Vaterland kann ruhig sein! Deze volksvijanden zijn ten minste onschadelijk (Hoen, 1940).

En op 6 november 1940 schrijft van der Does: "“De stroom van poezie blijft aanhouden, het is de enige uitlaat die we hebben." Deze teksten worden geregeld in dagboeken geciteerd en er zijn zelfs dagboeken die bijna uitsluitend uit dit soort liedteksten, verzen en 'moffenmoppen' bestaan. Op de melodie van "toen onze mop een mopje was" werd bijvoorbeeld gezongen: "Toen onze Sijs een sijsje was, toen woonde hij in Wien, Nu liegt hij alle dagen en steelt nog bovendien." Ook feestdagen zijn gelegenheden om door middel van geluid te protesteren.

Ook hoorde ik gisteren dat het hier in de stad met Oude Jaar een bende geweest is. Er was geen permissie gegeven na 12 uur op straat te zijn dus konden de menschen geen $N$. Jaar vieren met hun vrienden. Toch is er om 1.40, ons eigenlijke $N$. Jaar, groote drukte geweest. Loudspeakers uit de ramen, ketelmuziek, luid zingen van het Wilhelmus enz. Er is ook nog geschoten. Ons volk krijgen ze er niet onder (db: Bruijn-Barends, 04-01-1942).

Daar staat weer tegenover dat de Duitsers op 6 juli 1940 opdracht geven "tot het plaatsen van een muziektent op den Dam voor concerten van de Duitsche MuziekKapel" (Boer \& Duparc, 1948). De 'politiek van geluid' komt hier tot uitdrukking in de manier waarop beide 'kampen' omgaan met muziek en nationale identiteit. Ondanks een groot verschil in machtspositie en middelen, proberen beide kampen de 'muziek' van de ander niet te (hoeven) horen en hechten ze grote waarde aan het 'eigen' repertoire. Recente studies naar de creatie van dit zogenaamde 'eigen' of nationale repertoire, laten overigens zien dat niet de muziek zelf een nationale identiteit draagt, maar de praktijken waarin deze muziek gebruikt wordt (Revill, 2000; Trommler, 2004). 


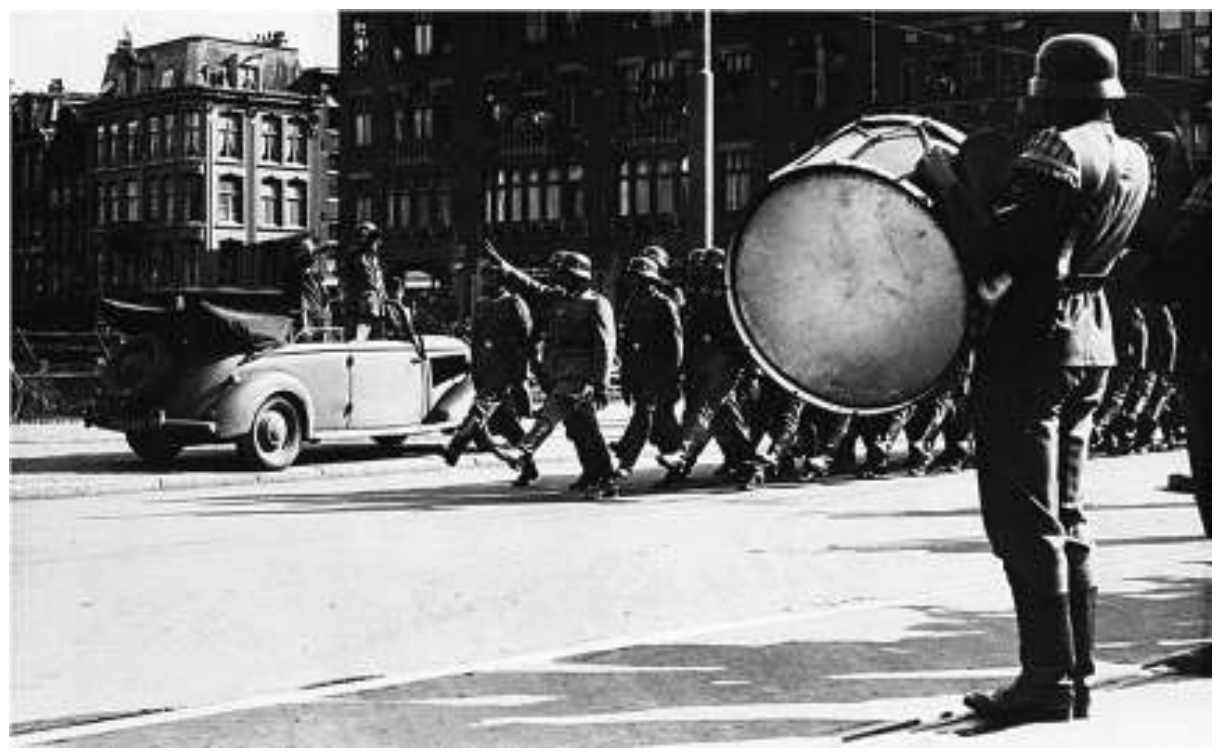

Afbeelding 17: Parade van Duitse soldaten op de Dam, februari 1941 (Stadsarchief Amsterdam)

In de dagboeken worden straatmuziek en draaiorgels verder niet genoemd. Volgens de Kroniek van Amsterdam mag er vanaf 7 oktober 1942 geen muziek meer worden gemaakt op straat ${ }^{170}$ en zijn ook draaiorgels verboden. ${ }^{171} \mathrm{Na}$ het verdwijnen van het lawaai van intens stedelijk verkeer, verliest het Amsterdamse klanklandschap opnieuw een karakteristiek geluid. Dat geluid keert aan het eind van de Hongerwinter weer terug als men wanhopig op zoek is naar voedsel. "Troepen kinderen trekken langs de huizen en vragen voedsel. In de winkelstraten staan bedelende vrouwen met kinderen en zingen. Ook in de omliggende polders wonende boeren worden afgestroopt. Tientallen straatmuzikanten verschijnen op straat" (db: Herks, 08-03-1945).

\footnotetext{
${ }^{170}$ Het is mij niet bekend of er in Amsterdam, net als in den Haag, aan het begin van de oorlog expliciet toestemming is gegeven voor het maken van muziek. Op 29 mei 1940 schrijft Het Vaderland: "Er mag weer muziek worden gemaakt: Op plaatsen waar dit vroeger veroorloofd was. De burgemeester van 'sGravenhage maakt in overeenstemming met de Duitsche militaire overheid bekend, dat het wederom toegestaan is muziek te doen maken door orkesten en draaiorgels op de plaatsen, waar dit voorheen was geoorloofd, zooals in cafés, bioscopen en op de openbare straat, echter met deze beperking dat geen muziek en liederen ten gehoore mogen worden gebracht, die van een aan Duitschland vijandige gezindheid blijk geven of van opwindenden aard zijn" (Het Vaderland, 29-05-1940, avond, p. 3).

${ }^{171}$ Marie van Dijk noemt in haar artikel Het beleid van de Amsterdamse overheid ten aanzien van straatmuzikanten 1900-1980 (Dijk, 1981) 11 september 1942 als het moment waarop "een besluit van de Duitsers definitief een einde maakt aan alle straatmuziek" (p. 150). Ze licht dat verder niet toe (ook geen bronvermelding).
} 
Een ander karakteristiek geluid van de stad - dat van klokken en carillons - verdwijnt in de loop van 1942 en 1943 ook grotendeels. ${ }^{172}$ Op 5 januari 1942 wordt nog het begin van wekelijkse carillon concerten op de Oude Kerkstoren, Westertoren en Zuiderkerkstoren aangekondigd, maar in de loop van juli 1942 besluit de bezetter ook carillons te confisqueren voor de oorlogsindustrie (Boer \& Duparc, 1948). Op 11 juli 1942, 4 dagen nadat ze ondergedoken zijn, schrijft Anne Frank in haar dagboek: "Vader, moeder en Margot kunnen nog steeds niet aan het geluid van de Westertorenklok wennen, die om het kwartier zegt hoe laat het is. Ik wel, ik vond het dadelijk fijn en vooral 's nachts is het zo iets vertrouwds." Ruim een jaar later blijkt de klok te zijn weggehaald. "We zijn sinds een week allemaal een beetje met de tijd in de war, daar onze lieve en dierbare Westertorenklok blijkbaar weggehaald is voor fabrieksgebruik en wij dag noch nacht precies weten hoe laat het is" (Frank \& Frank, 2008, p. 30; 116).

\section{Geluid en betekenis}

Bij het uitbreken van de oorlog wijzigt de betekenis of waardering van bepaalde geluiden en ook na de capitulatie breekt weer een nieuw 'geluidstijdperk' aan. Het afweergeschut bijvoorbeeld, is nu niet meer gericht tegen de 'vijand' maar tegen de 'vriend'. Daardoor wordt er anders geluisterd naar het geluid, ook al verandert er niets aan het geluid zelf of aan het potentiële gevaar dat het geschut voor de stedeling oplevert. "Woensdag 6 November 1940. Gisterenavond begon om acht uur het afweergeschut te dreunen, ook vannacht het zal zoowat één uur geweest zijn werden we wakker geschud door de kanonnen. Het is voor mij altijd een blij gehoor. Wat er gebeurd is, weten we niet en zekerheid daaromtrent krijgen we ook niet" ( $d b$ : van der Does).

Ook het luisteren naar de radio verandert als op 6 juli 1940 de kranten berichten "dat het niet langer geoorloofd is naar eenig buitenlandsch station te luisteren behalve naar die onder Duitsche contrôle, zulks om het ontvangen van onjuiste berichten tegen te gaan" ( $d b$ : van Buuren). Vanaf dit moment wordt er in het geheim naar buitenlandse zenders geluisterd en dat is niet zonder gevaar.

Ik herinner mij dat wij gehurkt zaten in de kamer bij onze buren, de heer $P$. af en toe de kamer verlatend (...) het huis omlopend in het donker om te zien of niemand in de buurt was; (...) men wendt telkens het hoofd om te zien, spitst het oor om te hooren en heeft de hand bij de radioknop om op het eerste verdachte geluid af te draaien. En telkens zijn er weer gevallen - 5 maanden gevangenisstraf en erger, en

\footnotetext{
172 "Als men bij helder weer en stralende zon in de morgenuren de stadhuisklok hoort kleppen en de carillons van de torens in de stad zingen, dan kost het moeite te bedenken welke ontzettende drama's in de lucht elders en aan de fronten zich afspelen" (db: Sander, 03-05-1943).
} 
hooge boetes - dat zij die naar de radio luisteren worden gepakt (db: Verwey, 2812-1940).

Voor en na de oorlog staat burengerucht voor het geluid van omwonenden dat men niet wil horen, voor overlast van de buren. Op een enkele uitzondering na verandert die situatie in de oorlog in het tegenovergestelde, zeker voor onderduikers. Het gaat er nu om dat de buren de geluiden die men zelf maakt niet horen. Uit het dagboek van Anne Frank blijkt hoe het hele doen en laten in het Achterhuis bepaald wordt door deze noodzakelijkheid. Een ander aangrijpend voorbeeld is te vinden in het dagboek van Hanemann-Keleman die maatregelen heeft getroffen om haar babydochter onder te laten duiken als een deportatie onafwendbaar lijkt:

Dann hebe ich sie heraus [uit de box], dabei zuckt mein Gesicht - sofort verzieht sich ihres zum Weinen. Ich zwinge mich zum lachen, denn wenn Bila jetzt weint, könnten Nachbarn aufmerksam werden, gerade was am dringendsten vermieden werden muss. Nur ein flüchtiger Kuss auf die süsse rosa Wange. Dann ist Nies mit dem Kind draussen (db: Hanemann - Keleman, 23-06-1943).

En mocht er toch sprake zijn van geluid van de buren, dan roept dat geen irritatie op maar is het eerder een geruststelling omdat het 'gelukkig maar' de buren zijn. "Hoe rustig wij langzamerhand zijn geworden, nog steeds schrikken wij op van een of ander geluid. Gisterenavond leek het precies, of iemand de trap op kwam. Tot twee maal toe gingen wij het bed uit om te zien of er niets was. Nu vanmiddag waren wij een moment overtuigd, dat iemand de straatdeur open deed. Het bleek echter evenals gisteravond burengerucht te zijn ( $\mathrm{db}$ : Koekenheim, 27-07-1942).

Tijdens de oorlog is het dag- en nachtritme voor een aantal jaren blijvend verbroken. Na de capitulatie zwijgt het luchtalarm tot eind augustus 1940 maar het geluid van overtrekkende vliegtuigen en luchtgevechten wordt in die periode wel gehoord, zowel 's nachts als overdag. Op 20 mei schrijft van Buuren dat zijn vrouw's nachts nog steeds naar de vliegtuigen luistert, maar dat hij zelf weer normaal slaapt. Eind mei heeft zijn vrouw pas weer haar eerste rustige nacht. Gedurende de maand juni hoort hij af en toe schieten, soms hevig of dichtbij, dan weer op grote afstand. Het geluid benoemt hij niet meer, ook schrijft hij niet meer over vliegtuigen maar over 'activiteit in de lucht'. Dan in de nacht van 6 juli 1940 is er een hevig luchtgevecht boven Amsterdam. "Om ongeveer 2.30 vanmorgen wakker door hevigste afweergeschutvuur dat we tot nu toe hoorden. Scherven vielen in onze straat. Om 4 uur begon het weer even fel" (db: van Buuren). Vanaf dit moment zal van Buuren, net als voor de capitulatie, het geluid van vliegtuigen en geschut weer regelmatig benoemen. Toch blijkt uit zijn woordkeuze dat hij een regelmatig terugkerend fenomeen beschrijft: "In den nacht steeds gebrom van vliegtuigen. Ver verwijderd geschutvuur" (9 juli); "Een paar luchtaanvallen met bijbehorend lawaai." (24 juli ); "Dan de gewone herrie van vliegtuig- 
geronk en afweergeschut. Een half uur later herhaling van de geheele geschiedenis" (27 juli).

Op momenten dat het oorlogsgeweld intens beleefd wordt omdat het nieuw is of dichtbij komt, besteden de dagboekschrijvers veel aandacht aan het geluid. Vliegtuigen blijken vooral te 'razen' en te 'ronken', het alarm te 'loeien' en het afweergeschut te 'dreunen'. Samen 'daveren' deze bronnen van geluid, vooral als ze zo dichtbij komen dat het geluid gevoeld wordt of het huis trilt.

Dit is wel de vreeselijkste nacht die we nog beleefd hebben. Het is zoo erg, zoo afschuwelijk geweest, dat ik voor het eerst echt bang geweest ben, en ik ben niet gauw bang. Om half 3 de $1^{\text {ste }}$ zware bommen; direct daarop een dreunend vuur, zoo hevig dat je lag te schudden in bed. Het duurde en duurde maar en nam in hevigheid steeds toe. Lichtflitsen dansten op en neer voor de ramen. Van uitkijken was geen sprake het was veel te gevaarlijk. Granaatscherven vielen in de straat, het was of alles zich recht boven je hoofd afspeelde. Men kon door het afweergeschut vaag de vliegtuigen hooren ronken. Of er luchtgevechten waren boven de stad, we weten het niet. Bij de ramen komen kon je niet voor het gevaar. Alles daverde en dreunde. Het verscheurt je zenuwen. Tot over 4-en duurde het zonder ophouden. (...) Nu, het is 10 uur, wordt er nog constant gevlogen het geronk is niet van de lucht. Doodmoe ben ik, 'geënerveerd'! We zijn er weer eens levend afgekomen. Voor hoelang? (db: Bruijn-Barends, 06-07-1940).

Voor volwassen dagboekschrijvers lijkt er later gewenning op te treden, al blijft men zich bewust van het gevaar. "Om 20.15 begon het schieten op overkomende vliegtuigen wat met eenige korte onderbrekingen door ging tot 22.15. Twee uur lang gedaver en gerommel, maar we luisteren er al haast niet meer naar. De radio speelt door en we lezen een boek, zonder veel acht te slaan op wat er buiten omgaat" (db: van Buuren, 27-01-1942). Voor het cluster van luchtalarm en het geluid van vliegtuigen en schieten worden nu metaforen gebruikt als 'voorstelling', 'concert' of 'feest'. Aan een dergelijk 'feest' verleent men dan geen medewerking door in slaap te vallen ( $\mathrm{db}$ : van Buuren, 27-03-1943). Bovendien geven een aantal auteurs aan dat het geluid van vliegtuigen en alarm blijdschap oproept: "Als er luchtalarm komt hoor je onmiddellijk juichen op straat: daar zijn ze gelukkig weer!! Bang is niemand. Ze krijgen ons niet de moffen" (db: Bruijn-Barends, 23-06-1943).

Anne Frank die bijna 11 jaar oud is als de oorlog uitbreekt, geeft wel aan aldoor bang te zijn voor wat zij meestal 'schieten' noemt. In de nacht zoekt ze dan troost bij haar vader (p. 112). Op 2 juni 1944, als ze bijna 2 jaar ondergedoken zit, heeft ze "een gloednieuw recept antischieten mee te delen" (p.274). Dit recept houdt in dat men bij "harde paffers" een houten trap op en af moet rennen. Bij voorkeur valt men ook zo nu en dan voorzichtig van die trap af, want dat helpt om niet aan het schieten te hoeven denken. Het 'eigen' lawaai zorgt er voor dat het schieten niet meer gehoord 
wordt. Ook uit het dagboek van Verwey blijkt dat zijn kinderen nog steeds erg bang zijn voor deze geluiden op het moment dat hij er zelf aan gewend raakt:

De geheele nacht door geloei van de sirene en schieten, - kleine Ger alsmaar huilen, Abje te trillen in zijn bed, William met open oogen.- geheele familie wakker. (...) 8.30. Bommen vallen, de sirene loeit. Het geschut dreunt. We raken er aan gewend. Opmerkelijk is dat wij nu rustig doorwerken en doen alsof niets aan de hand is. Het besef van fataliteit is toegenomen (db; Verwey, 15-06-1940).

Naast het geluid van luchtgevechten en bombardementen, verbindt de terreur van het nazibewind gaandeweg een scala aan angstaanjagende betekenissen aan alledaagse geluiden als bijvoorbeeld de tingel van een deurbel of voetstappen. "Hoor een stap in het portiek. Als ik iets hoor krijg ik een doodstuip. Zo gaat 't van 8 uur tot 1 uur 's nachts" (db: Spruit-Duis, 25-09-1942). In haar dagboekbrief van 3 februari 1943 concludeert Mirjam Levie daarover het volgende: "Je weet niet, hoe volkomen uit ons lood we zijn. Als er gebeld wordt, schrikken we. Als er een beetje hard geluid op straat is, bv. Het knallen van een auto, krimpen we in elkaar. We hebben de Duitse joden beklaagd, als ze van ieder geluid schrokken, maar we zijn zelf allang zover" (Bolle, 2003, p. 53).

Over het geluid dat de razzia's omgaf, is niet veel geschreven. Zij die werden weggevoerd, kregen er alleen in uitzonderlijke gevallen nog de gelegenheid voor. En zelfs dan zal het slechts enkelen gegeven zijn om er nog over te kunnen schrijven. Schreeuwende soldaten en huilen horen er in ieder geval bij, maar ook stilte en met stomheid geslagen worden.

Dann, um 12 Uhr, kommen die Lautsprecher auf der Merwedeplein. Ich mache mich rasch fertig. Es läutet, 2 Grüne. Erst bei Müller, 120-er. Darf bleiben. Auch Manzi ist da und darb bleiben. Dann bei uns. Wir sind Litauer, damit kann man nichts anfangen. Kommen Sie mit. Haben Sie Kinder? Nein. Sie laufen durch die Wohnung, reissen alles auf, finden glücklich nichts. (...)

Ich rufe zu Müller und Manzi: "Lebt wohl!" mit lauter, harter Stimme. Sie antworten nicht. Furcht - oder Scham, zurückzubleiben?

Der Merwedeplein ist voll von Juden und Grünen. Vorher schon sind lange, traurige Reihen bepackter Juden durch den Merwedeplein gewandert mit Kindern im Kinderwagen, an der Hand, auf dem Arm. Rücksäcke, Bündel, Decken, Kopftücher, vereinzelte Hüte, die grotesk zu den Rücksäcken stehen. Weinende, klagende und ruhige. Und die Kinder! Und die schreienden Grünen, und die Zuschauer, mehr oder weniger teilnahmsvoll, und die NSB'er (db: Hanemann-Keleman, 23-06-1943). 
Degenen die bleven konden er moeilijk mee omgaan en ontbrak het bovendien aan de kennis die we nu hebben. Daardoor zijn teksten van niet-joodse bewoners die joden toch een warm hart toedragen in onze ogen vaak onthutsend afstandelijk: "Vanavond in onze straat Jodenarrestaties. Een overvalwagen der Groene politie verscheen, enkele Joden werden er ingeladen, en verdween weer. Overvliegen schijnt voorbij te zijn. Avond na avond, nacht na nacht gaat voorbij en alles blijft stil!" (db: van Buuren, 01-10-1942). Maar ook met wat we nu weten blijven het gebeurtenissen die niet te bevatten zijn. Daarom worden de absurde en mensonterende situaties waarmee vooral joodse Amsterdammers te maken kregen, misschien nog het beste gesymboliseerd door de volgende niet van humor gespeende observatie: "Nach einigen Monaten wurden die Parks “Für Juden verboten!" und wir waren in Verlegenheit wenn Tipsy [de hond] in den Beatrixpark lief, dort bellte und auf unser rufen nicht herauskam" (db: Hanemann-Keleman, p 1-6).

\section{Conclusie}

Oorlogsgeluid in de vorm van luchtalarm en het geluid van vliegtuigen en geschut dat bovendien het dag- en nachtritme regelmatig verbreekt, zorgen voor een grote verandering in het Amsterdamse klanklandschap. Vergeleken met de situatie voor de oorlog, die nog ver afstond van het round-the-clock leven van de eenentwintigste eeuw, vraagt dat des te meer om aanpassing. "Het was weer eens een ouderwetsche beroerde nacht. Zeker zijn we hier nooit maar als het een paar nachten rustig is geweest krijg je het gevoel "nu laten ze ons eindelijk eens met rust." Nu zijn we dat vertrouwen weer kwijt" (db: Bruijn-Barends, 30-10-1940).

De oorlog doorbreekt niet alleen het ritme van dagen nacht, maar plaatst ook het geluid van de buren in een nieuwe context. Vóór de oorlog is het geluid van omwonenden gemakkelijk een bron van ergernis, maar tijdens de bezetting vormen dezelfde geluiden een geruststellend teken van de aanwezigheid en dagelijkse routine van buren. Verder is het voor onderduikers van levensbelang om zelf niet te worden gehoord. Men moet zo min mogelijk geluid maken en er in ieder geval voor zorgen dat geluiden binnenshuis blijven. Deze verschuivingen in de aandacht voor de richting van het geluid, dat wil zeggen van buiten naar binnen en omgekeerd, gaat vergezeld van extra aandacht voor de locatie van geluidsbronnen. Het geluid van vliegtuigen of geschut dat dichterbij komt, maar ook nachtelijke voetstappen op straat of in het portiek van de woning kunnen nu immers wijzen op levensbedreigend gevaar.

In de Amsterdamse oorlogsdagboeken is een klanklandschap te beluisteren dat gekenmerkt wordt door tegengestelde bewegingen. Enerzijds is er het oorlogsgeluid in de vorm van luchtalarm, vliegtuigen en afweergeschut dat Amsterdammers dag en nacht meezuigt in turbulente ontwikkelingen op wereldschaal. Anderzijds is daar een stad die door het verdwijnen van vertrouwde geluiden almaar stiller wordt. Oorlogs- 
ervaringen in de stad blijken niet alleen verbonden met oorverdovend lawaai, maar ook met stilte, muziek en alledaagse geluiden.

Muziek speelt zowel bij de bewoners van Amsterdam als bij de bezettingsmacht een belangrijke rol bij het uitdrukken van de nationale identiteit. Het is een duidelijk voorbeeld van de 'politiek van geluid'. Hoewel men grote waarde hecht aan het 'eigen' repertoire, is het toch niet zozeer de muziek zelf als de praktijk waarin deze gemaakt of beluisterd wordt die zorgt voor de associatie met het eigen land of volk. Bovendien draagt ook het niet-luisteren naar of negeren van de muziek of de geluiden van het andere kamp deze politieke lading.

Het geluid van de stad zelf verandert vooral door het verdwijnen van de vertrouwde geluiden van gemotoriseerd verkeer, mensen, muziek op straat, klokken en carillons. Het lawaai van de stad, haar bewoners en het verkeer zijn herinneringen aan betere tijden en worden nu gemist. "Het is zoo griezelig stil op straat. De lucht zit vol onheil" (db: (Bruijn-Barends, 24-02-1941). De stad is "arm, verlaten, smerig" (Bolle, 2003, p. 98), wordt alsmaar stiller en lijkt terug te keren in de tijd. Stilte betekent nu ook niet weten wat er te gebeuren staat. "De nacht was angstwekkend stil, geen vliegmachines, geen luchtafweergeschut, geen kogels, geen autogerij op de wegen, geen trams of troepenverkeer. Worden wakker in het besef dat de strijd op zee kan zijn begonnen, maar de melkboer weet van niets en de menschen gaan nog gewoon hun gang." (db: Verwey, 09-09-1940). Bovendien kan stilte verraderlijk zijn als je zelf niet gehoord wilt worden.

De frequentie waarmee het schieten, de vliegtuigen en het luchtalarm in de dagboeken aan de orde komt, vertelt ons hoe belangrijk deze geluiden waren in de stad. Vergelijking van de verschillende reacties van enerzijds de bewoners van Amsterdam en Düsseldorf en anderzijds volwassenen en kinderen (beiden in Amsterdam), laten bovendien zien hoe sterk de betekenis van geluid samenhangt met informatie over of inzicht in de context van dat geluid. Ook in Düsseldorf is het geluid van geschut, vliegtuigen en het alarm veelvuldig te horen (Birdsall, 2010, p. 150). Toch zorgt het verschil tussen de situatie in beide steden er in de eerste plaats voor dat de verandering in de beoordeling van deze typische oorlogsgeluiden tegengesteld verloopt. In Amsterdam wordt de eerste onderkoelde reactie op deze geluiden gevolgd door schrik als het gevaar dichtbij komt, en daarna door een toenemende gewenning en vaak zelfs blijdschap. In Düsseldorf verandert de euforie die deze geluiden in mei 1940 nog oproepen vrij snel in het tegendeel.

Volwassenen in Düsseldorf weten dat ze gevaar lopen en dat het luchtalarm cruciale informatie verstrekt. Daar wordt het luchtalarm dan ook het meest genoemd en bovendien aangewezen als het geluid dat de grootste invloed heeft op de dagelijkse gang van zaken (Birdsall, 2010, pp. 144-145). Volwassenen in Amsterdam daarentegen weten op een gegeven moment dat hun stad niet de eindbestemming is van de bommenwerpers die ze horen en dat er bovendien geen directe relatie is tussen luchtalarm en werkelijk gevaar. De angst die het luchtalarm aanvankelijk oproept gaat over in het 
negeren van dit geluid als blijkt dat dit signaal niet betrouwbaar is. Het geluid van de vliegtuigen en het afweergeschut gaat dan een veel grotere rol spelen. Kinderen en jongeren in Amsterdam echter blijven bang voor alle oorlogsgeluiden omdat zij niet over dit grotere perspectief beschikken.

Naast voornoemde oorlogsgeluiden worden Amsterdamse bewoners die als Jood worden aangemerkt of die een andere reden hebben om de politie en de bezettingsmacht te vrezen, bovendien geconfronteerd met het gegeven dat alledaagse geluiden als voetstappen op straat, een auto of de deurbel een gruwelijke betekenis kunnen dragen. De eerder geciteerde opmerking van Mirjam Levie dat ze voorafgaand aan de oorlog de Duitse vluchtelingen beklaagde omdat ze van alle geluiden schrokken, maar begin 1943 zelf 'allang zover' is, toont aan hoe ontwrichtend maar ook hoe moeilijk voorstelbaar een dergelijke situatie is.

Alvorens we in deze dissertatie gingen 'luisteren' naar het Amsterdamse klanklandschap, is uiteengezet dat het begrip soundscape zowel betrekking heeft op een wereld buiten de mens - de geluiden die mensen omringen - als op datgene waarmee de mens die buitenwereld probeert te begrijpen. Uit dit onderzoek naar geluid in de oorlog blijkt eens te meer dat we niet genoeg hebben aan geluidsopnames als we willen begrijpen hoe klanklandschappen van een roerige historische periode door tijdgenoten werden waargenomen en beoordeeld. Het toekennen van betekenis aan een geluid is afhankelijk van inzicht in de activiteit die dat geluid voortbrengt en in de rol van die activiteit in een groter geheel. Zonder over deze aan tijd en plaats gebonden informatie te beschikken, is het niet mogelijk om te begrijpen wat de geluiden voor tijdgenoten betekenden. Dit verklaart ook waarom niet zozeer de instrumentale muziek zelf, maar de culturele praktijk waarin ze gebruikt wordt uitdrukking geeft aan nationale identiteit, verzet of welke politieke boodschap dan ook. In het verlengde daarvan is het eveneens te begrijpen dat de inzet van geluidstechnologieën door de nazi's, zoals beschreven door Birdsall, enkel in volledig te regisseren situaties succesvol waren. Hoe intimiderend geluiden op zichzelf kunnen zijn, zeker als de trillingen gevoeld worden zoals bij laag overvliegende vliegtuigen en inslaande projectielen, toch kunnen zij qua betekenis en directe invloed voor tijdgenoten in het niet vallen bij de klank van een deurbel. In instabiele situaties als oorlogen en andere gevaarlijke omstandigheden blijkt de betekenis van een geluid net zo vluchtig als het geluid zelf. 



\section{Waarom Amsterdam vroeger ook niet stil was: Conclusie}

\section{Stadsgeluid: ‘Oor’zaak en discours}

Deze dissertatie gaat over geluid als deel van het dagelijks leven in de stad. Geluid dat al dan niet opzettelijk wordt gemaakt, geluid waaraan aandacht wordt besteed of juist niet, geluid dat commotie veroorzaakt, discussies oproept en acties om het te veranderen. Aanleiding voor deze focus op stadsgeluid is de volgende paradoxale situatie. Enerzijds is er de wijdverbreide opvatting dat steden door groei, industrialisatie en technologisering van de samenleving al maar lawaaiiger worden (Hendy, 2013, pp. xiixiii). Anderzijds weten we heel weinig van het geluid in vroegere steden en van de rol die dat geluid speelde in het dagelijkse leven. Toch ligt aan het idee dat steden steeds lawaaieriger worden een vergelijking met het verleden ten grondslag. Het lijkt er op dat de voortdurende opkomst van nieuwe bronnen van geluid en een gebrekkige herinnering aan bronnen die verdwenen zijn, aanleiding geven tot de conclusie dat het vroeger stiller was. Zoals deze dissertatie laat zien, is het echter bij vraagstukken over meer of minder stilte en lawaai, om het even of het over de actualiteit of het verleden gaat, niet voldoende om uitsluitend aandacht te besteden aan de oorzaken van geluid. Om dit te illustreren vergelijken we twee teksten over verkeerslawaai (zie de tekst box op de volgende pagina).

Beide teksten zijn onderdeel van artikelen die pleiten voor een nieuwe aanpak in de straten van Amsterdam. Het fragment uit 1889 is een hartstochtelijk pleidooi voor het vervangen van de keienbestrating door asfalt omdat daar een beschavende invloed van zal uitgaan. In de tekst die 120 jaar later verschijnt, worden met andere bewoordingen maar met evenveel passie statistische gegevens en deskundigen aangevoerd om de negatieve invloed van verkeersgeluid op de gezondheid te staven. Hoewel lezers uit de eenentwintigste eeuw de honderdtwintig jaar oude tekst vanwege woordkeuze, redeneerstijl en aangevoerde argumenten vermoedelijk niet overtuigend zullen vinden en misschien zelfs geëxalteerd of onnozel, is er geen reden om te twijfelen aan de serieuze intentie van beide teksten. Het zijn oprechte pogingen om bij te dragen aan het terugdringen van lawaai in Amsterdamse straten op een manier die herkenbaar, rationeel en overtuigend is voor tijdgenoten. Bijgevolg 'glijden' in 1889 de wielen, die hoogstwaarschijnlijk van ijzer zijn, 'onhoorbaar' over het asfalt en leiden zo tot toenemende beschaving, terwijl in $\mathbf{2 0 0 9}$ het geluid van rubberen banden over het wegdek voor overlast en gezondheidsproblemen zorgt. Aan het einde van de negentiende eeuw worden ruwe kerels, brullende venters en schreeuwende straatjongens onder invloed van het asfalt buigzaam en gedwee. In het begin van de eenentwintigste 
eeuw daarentegen, loopt een op de vijf Amsterdammers het gevaar ziek te worden van verkeerslawaai. De voorbeelden laten zien hoe sterk het discours over geluid in de loop van de tijd verandert en hoe bepalend de kijk op mens en samenleving is voor uitspraken over meer of minder stilte en voor de manier waarop deze worden onderbouwd. Veranderingen in stadsgeluid en lawaai kunnen daarom onmogelijk alleen op basis van materiële ontwikkelingen in het dagelijks leven en de stad worden begrepen en verklaard.

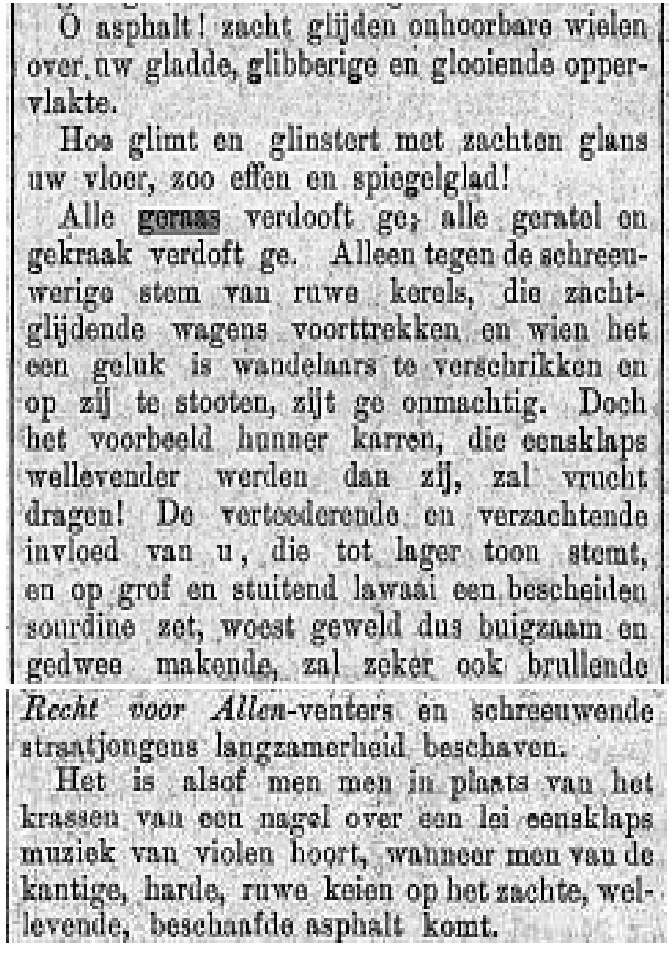

'Van dag tot dag', Algemeen Handelsblad, 07-02-1889, ochtend, p. 3.
Geluid: minder lawaai

Verkeerslawaai is een resultante van de hoeveelheid verkeer, de concentratie van voertuigen, het soort voertuigen, de snelheid waarmee die voertuigen zich voortbewegen en het soort wegdek waarover dat gebeurt. Oorzaken zijn het geluid van motoren en het geluid van rollende banden over het wegdek.

Ongeveer één op de vijf Amsterdammers ondervindt veel geluidsoverlast. De meeste overlast wordt veroorzaakt door wegverkeer. Geluidsoverlast tast de leefbaarheid aan en kan leiden tot gezondheidsproblemen zoals verstoring van het slaapritme. Volgens deskundigen zijn de gezondheidseffecten door geluidhinder minstens zo ernstig als de gezondheidseffecten van luchtvervuiling.

In deze dissertatie is de samenhang in kaart gebracht tussen de geluiden die in een bepaald tijdvak in de stad worden geproduceerd en de plaats die aan deze geluiden in het dagelijks leven wordt toegekend. Daarbij is bovendien gezocht naar mechanismen die verklaren waarom sommige geluiden aandacht krijgen en eventueel tot ongewenst geluid of lawaai worden verklaard en andere ogenschijnlijk vergelijkbare geluiden genegeerd worden.

Het onderzoek is toegespitst op drie tijdvakken waarvan bekend is dat er op het vlak van geluid veel veranderingen plaatsvonden in Amsterdam: de periodes 1875$1895,1918-1940$ en 1940-1945. Bovendien heeft ook het analyse raamwerk dat hier is 
toegepast - en dat verderop zal worden toegelicht - een rol gespeeld bij de selectie van deze casussen. Naast een systematische analyse van elke casus met behulp van alle drie de perspectieven van het raamwerk, bieden de gekozen tijdvakken de mogelijkheid om telkens één van de perspectieven nader uit te werken. Het laatste kwart van de negentiende eeuw is een tijdvak waarin Amsterdam geconfronteerd wordt met bevolkingsgroei, industrialisering, technologisering en het geluid van de 'moderne' stad. Hoewel deze trend van groei en ontwikkeling zich in het interbellum aanvankelijk voortzet, gaan geluid en lawaai in deze periode een veel grotere rol spelen in discussies over het stadsleven dan aan het einde van de negentiende eeuw het geval was. De Tweede Wereldoorlog tenslotte, is een belangrijke casus omdat de stad dan plotseling te maken krijgt met nieuw geluid, met sterk veranderende betekenissen van geluid en met het verdwijnen van vertrouwde klanken.

Voor elk van de genoemde tijdvakken zijn vragen beantwoord die samenhangen met het analytische raamwerk dat in dit onderzoek is toegepast. Op het vlak van de geluiden in de leefomgeving van de mens, het onderdeel van het raamwerk dat 'ecologie van geluid' is genoemd, ging het om de vragen welke actuele stadsgeluiden genoemd worden in teksten uit de betreffende periode, welke bronnen van geluid verder nog aanwezig zijn en welke veranderingen zich voordoen in de aard, het aantal en het volume van die geluiden. Bij het tweede deel van het analyse raamwerk, de 'semiotiek van geluid', staat de betekenis van geluid centraal en werd ingegaan op de manier waarop stadsgeluiden worden besproken en op de betekenissen die er in de teksten aan worden toegekend. Het derde perspectief, de 'politiek van geluid', richt de aandacht op geluid als onderdeel van politieke en sociale kwesties. Hierbij ging het om de vraag in hoeverre er in de betreffende periode geluid wordt gemaakt om de aandacht te vestigen op bepaalde situaties of opvattingen. En of er interventies ter bestrijding van stadsgeluiden worden voorgesteld en/of uitgevoerd en welke dat dan zijn. Tenslotte zijn mede op basis van de antwoorden op voorgaande vragen verklaringsmechanismen aangevoerd voor de verschillen tussen de productie van geluiden, het bespreken van geluiden en het interveniëren in en met geluiden in een bepaalde periode.

\section{Stadsgeluid in de laat negentiende en vroeg twintigste eeuw}

Periode 1875 - 1895

Het eerder besproken tekstfragment uit 1889 geeft een karakteristiek voorbeeld van het discours over geluid in het laatste kwart van de negentiende eeuw. In deze periode krijgt Amsterdam niet alleen te maken met een sterke groei van de bevolking, van de handel en van bepaalde vormen van nijverheid, maar ook met de aandrijving van productieprocessen door stoommachines. De toegenomen bedrijvigheid betekent ook dat het verkeer toeneemt, dat wil zeggen meer voetgangers, handkarren en door 
paarden getrokken vrachtwagens, trams en rijtuigen in de straat en af en toe een stoomboot op de waterwegen in de stad. Het merendeel van de activiteiten speelt zich aanvankelijk af in het gebied binnen de singelgracht. Daar bevindt zich ook het grootste deel van het woningenbestand, dat lang niet voldoende is om de uitdijende stadsbevolking te huisvesten. Grote groepen Amsterdammers huizen dan ook opeengepakt in eenkamerwoningen waar soms ook nog een beroep wordt uitgeoefend. ${ }^{173}$ Voorts zijn industrie en nijverheid op loopafstand gevestigd, want fietsen zijn nog geen vervoermiddel en de tram is te duur voor arbeiders.

Tegen de achtergrond van al deze bedrijvigheid en erbarmelijke leefomstandigheden voor een aanzienlijk deel van de bevolking, is er in deze periode opvallend veel aandacht voor de menselijke stem, klokken en muziek, weinig voor het geluid van verkeer en nauwelijks voor het geluid van ambachtelijke en industriële activiteiten. Zoals ook de tekst uit 1889 laat zien, denkt en schrijft men over geluid vanuit de tegenstelling muziek versus niet-muziek. Muziektermen spelen daarom een grote rol in het jargon. Wanneer wagenwielen van de straatkeien op asfaltbestrating rollen, klinkt dat als muziek van violen. Asfalt stemt "tot lagere toon" en "zet een bescheiden sourdine ${ }^{174}$ op grof en stuitend lawaai." De woorden 'lawaai' en 'herrie' kunnen duiden op veel geluid, maar worden vooral gebruikt om gebrek aan orde, uitingen van protest, afwijkende meningen en holle praatjes aan te duiden. Het woord 'geluid' wordt opvallend vaak gebruikt voor de stem van een zanger: hij of zij heeft een mooi geluid. En waar wij van 'lawaai' zouden spreken gebruikt men de woorden 'gedruisch' en 'geraas'.

Het denken over geluid in termen van muziek en niet-muziek houdt in dat muziek het ideaal vertegenwoordigt en dat alle andere geluiden kwalitatief de mindere zijn. Deze beschouwingswijze zorgt er ook voor dat de aandacht vooral op stemmen en muziekinstrumenten, in theorie de bronnen van ideaal geluid, is gericht. In die context is ongewenst geluid het geluid van stemmen en carillonmuziek dat buitenlandse bezoekers uit hun slaap houdt en hen doet klagen over de onmuzikale oren en stemmen van de Nederlanders. Amsterdammers op hun beurt klagen meestal over de stemmen en muziek van het "mindere volk" of "gemeen", het deel van de bevolking dat "buigzaam en gedwee" dient te zijn. Wanneer zij toch van zich laten horen - zoals de "ruwe kerels, brullende venters en schreeuwende straatjongens" - dan is dat een aantasting van de gevestigde orde en haar beschaving. En zo valt het ook te begrijpen dat, zoals we aan het einde van hoofdstuk drie hebben gezien, het geluid van fabrieken

\footnotetext{
${ }^{173}$ Rond 1860 bestond 60 tot $70 \%$ van de stedelijke bevolking uit bedeelden, minvermogende paupers, kleine neringdoenden, werklieden en dienstpersoneel. Ongeveer 25 tot 35\% behoorden tot de middengroepen en 4 tot $7 \%$ tot de gegoede en vermogende stand. Ondanks de stijging van de welvaart tussen 1870 en 1914 en het feit dat de grote massa daarin een bescheiden aandeel had, leefden veel Amsterdammers in het begin van de twintigste eeuw nog steeds in armoedige omstandigheden (Klerk, 2008).

${ }^{174}$ Een 'sourdine' is een demper die wordt gebruikt om het geluid van een muziekinstrument te beperken of de klank te veranderen.
} 
geen probleem is dat om publieke aandacht vraagt, maar "verwerpelijke liederen" van de arbeiders wel. Al moet natuurlijk ook niet vergeten worden dat de kloof tussen proletariërs en bourgeoisie in deze tijd nog groot is. In de beschikbare teksten horen we enkel de mening van de zogenaamde 'hoedenmens', want de 'pettenmens' schrijft dan nog geen boeken en brieven aan krant of gemeente.

Periode 1918 - 1940

Vergeleken met het einde van de negentiende eeuw, klinkt het discours over geluid en de stad in het interbellum heel anders. Onderstaand fragment is afkomstig uit een artikel over 'Grootestads-rumoer' dat volgens de anonieme auteur een onderwerp is waarover overal ter wereld wordt geklaagd maar waarvoor nog nergens een oplossing is gevonden. Geluid is in deze tijd vooral een fenomeen dat inwerkt op het oor en 'de zenuwen' van de mens en dat door trilling en intensiteit wordt gekenmerkt. In deze periode worden bovendien verschillende meetmethoden en meeteenheden voor geluid ontwikkeld, waaronder de bekende decibel. In tegenstelling tot de negentiende eeuw worden de woorden 'geluid', 'lawaai' en 'straatrumoer' nu meestal gebruikt op de manier die ons vertrouwd is.

Hoofdoorzaak van het signalen-lawaai - evenals van alle verkeersperikelen - is nu eenmaal: de aangeboren onwellevendheid van vele menschen. En bij onvoldoende toezicht op het verkeer bestaat altijd het gevaar, dat de goeden onder de kwaden lijden, m.a.w. de rustigen door de woestelingen overhoop worden gereden. (...) Natuurlijk wordt een stad niet rustig, ook al werd zij slechts bereden door voorbeeldige, ingetogen automobilisten. Er zijn nog tallooze andere geluiden, die tot het straatrumoer bijdragen. Treffend kan men dit constateeren als, door een storing, eens de geheele tram stroomloos is; of als er dik sneeuw is gevallen, waardoor alle geluiden, die door wrijving van wielen, raderen, paardenhoeven enz. met het wegdek worden veroorzaakt, worden gedempt. Verder denke men aan straatventers, kleedjesklopsters, putzuigers, draaiorgels, keffende honden en schreeuwende kinderen ('Grootestads-rumoer en wat er tegen te doen is', Algemeen Handelsblad, 14-04-1934, avondblad).

Hoewel er bronnen van geluid genoemd worden die ook voorkomen in de tekst over asfaltering uit 1889, zoals wielen en paardenhoeven op het wegdek, geschreeuw van venters en kinderen, zijn er redenen om aan te nemen dat de klank van het verkeer sindsdien sterk is veranderd. Het merendeel van de straten is inmiddels met asfalt bedekt en wielen zijn voorzien van luchtbanden. Dit dempt een deel van de geluiden. Maar de door paarden getrokken trams, wagens, en rijtuigen zijn vervangen door elektrische trams, vrachtwagens en auto's en bovendien is het aantal voertuigen in absolute zin fors toegenomen. Omdat al deze bronnen van geluid in samenklank 
bijdragen aan de maskering van afzonderlijke geluiden en het verkeer met grotere snelheid beweegt, moeten de voortuigen hun komst aankondigen met belsignalen en claxongetoeter. Desondanks komen paard en wagen nog wel voor in de stad, evenals handkarren en venters. Nieuw is ook de grote horde fietsers die, samen met de uitbreiding van het tramnetwerk, een belangrijke rol spelen in het woon-werkverkeer. De intensiteit van het verkeer en de variatie in snelle en langzame deelnemers, vraagt om een ander gedrag in het verkeer en een gewijzigd gebruik van de straat. Dit veranderingsproces zorgt tot ver in de jaren dertig voor het 'signalen-lawaai' dat in de tekst wordt genoemd.

Verder worden in deze periode woon- en werklocaties steeds meer van elkaar gescheiden. Industrieën en nijverheid hoeven niet langer op loopafstand te worden gesitueerd en door annexatie van omliggende gemeenten ontstaat er een rand van woonbuurten rondom de oude stad. In die buurten krijgen de Amsterdammers, die voorheen in overvolle buurten en deplorabele huizen in de oude stad woonden, te maken met ruimere woningen en een relatief stille woonomgeving. Voorts resulteert de stijging van de welvaart en de regulering van arbeidsomstandigheden in een toename van vrije tijd.

In die stilte en rust dringen eventuele geluiden zich veel meer op, waardoor het geluid van de buren gemakkelijk een bron van ergernis kan worden. Bovendien is het strikte onderscheid tussen hoeden- en pettenmensen geleidelijk op de achtergrond verdwenen ten gunste van een veel diffusere maar daarom ook moeilijker te doorgronden opbouw van de samenleving. Via de krant en de radio, die in bijna alle lagen van de maatschappij doordringen, hoort men over de licht- en schaduwkanten van het zinnenprikkelende leven in Amerikaanse metropolen. In die context wordt ongewenst geluid in Amsterdam niet langer alleen maar in verband gebracht met 'het gemeen' maar met de op Amerikaanse leest geschoeide 'massamens' die door zijn "aangeboren onwellevendheid" meegesleept wordt door jazzmuziek, onbetamelijke dansen, de bioscoop en ander goedkoop vermaak en niet in staat is om op een verantwoorde wijze om te gaan met zijn of haar radio, grammofoon, motorfiets of auto.

\section{De Tweede Wereldoorlog}

De Tweede Wereldoorlog wordt in Amsterdam aangekondigd door het nachtelijk geluid van vliegtuigen en afweergeschut. Bovendien vormt dit geluid, samen met de sirenes van het luchtalarm, voor heel wat inwoners de meest directe ervaring van oorlogsgeweld in de dagen voorafgaand aan de capitulatie. Als vervolgens op 16 mei het dagelijks leven weer min of meer op gang komt, valt het op hoe stil de stad is nu er in vergelijking tot de vooroorlogse periode bijna geen auto's en bussen meer rijden.

Nadat het uitbreken van de oorlog voor abrupte veranderingen in de betekenis van bepaalde geluiden heeft gezorgd, het geluid van vliegtuigen bijvoorbeeld waarschuwt vanaf dat moment voor een mogelijk levensgevaarlijke situatie, brengt ook de 
capitulatie nieuwe betekenissen met zich mee. Zo is het afweergeschut niet meer gericht tegen de 'vijand' maar tegen de 'vriend'. Daardoor wordt er anders naar geluisterd, al verandert er niets aan het geluid zelf of aan het potentiële gevaar dat het geschut voor de stedeling oplevert.

Het geluid van oorlogsactiviteiten brengt ook nieuwe uitdrukkingen met zich mee: het afweergeschut 'blaft' of 'tettert' en de sirenes 'loeien' en 'huilen'. Het discours over stadsgeluid verandert net zo abrupt als de betekenis van bepaald geluid, al blijft de manier waarop geluid als natuurkundig fenomeen begrepen wordt en het jargon waarmee er over geschreven wordt hetzelfde. Het verkeersgeluid, dat tijdens het interbellum aanleiding gaf tot discussies en klachten, wordt nu gemist als een teken van betere tijden. Ook het geluid van de buren vormt geen reden meer tot klagen. Het is nu een geruststellend teken van hun aanwezigheid of, in de situatie dat de buren gewild of ongewild een gevaar zouden kunnen vormen, een belangrijke bron van informatie. Gaandeweg de oorlog wordt de stilte in de stad een teken van het gedwongen vertrek van vele inwoners en het onzekere lot dat ze tegemoet zijn gegaan. Behalve het geluid van vliegtuigen, afweergeschut, sirenes en schieten is dus ook stilte een indringend 'oorlogsgeluid'.

Van 10 - 10.20 uur luchtalarm. Geen actie. De voorstad waarin wij wonen, is geheel afgezet door de Duitsche politie, die niemand laat doorgaan, niet er uit en niet er in. Om 3.30 vannacht zouden er wagens met luidsprekers rondgereden hebben, die waarschuwden dat Ariërs binnen moesten blijven. Identiteitspapieren worden gecontroleerd van het publiek op de straat. Van $12.45-13$ uur luchtalarm. Zie boven. Zijn om 14.30 uitgegaan. De geheele Watergraafsmeer was erg stil. Het was mooi weer en vooral op Zondagen zijn er duizenden wandelaars. Nu niets van dit alles. Alle sportvelden leeg. De trams reden niet. Er zouden veel Joden gearresteerd zijn. Van 16.10 - 16.30 luchtalarm. Zeer hoog trokken er wat vreemde vliegtuigen over, ver daaronder wat Duitsche machines. Er werd verweg nog even geschoten (db: van Buuren, 20-06-1943).

Volwassenen zijn, soms tot hun eigen verbazing, in staat om zich snel aan te passen aan het oorlogsgeluid, maar voor jongeren en kinderen blijft het intense geluid van afweergeschut, explosies en sirenes beangstigend. De bezettingsmacht is over het algemeen ongewenst en het geluid dat ze maakt daarom ook. Dit heeft tot gevolg dat dit geluid in het discours, of genegeerd wordt, of getypeerd als geschreeuw, gebrul, lawaai of herrie. Naast deze vorm van 'politiek van geluid' waarbij het geluid symbool staat voor een situatie die men verafschuwt, wordt er in de oorlog door beide partijen politiek bedreven met behulp van muziek. De bezetter organiseert muziekvoorstellingen en parades in de stad en voor de Amsterdammers gaat het Wilhelmus en andere muziek die geassocieerd wordt met de Nederlandse identiteit een grote rol spelen als teken van verzet en onverzettelijkheid. 


\section{Geluid en geschiedenis}

Elk van de voorgaande casussen geeft een indruk van het dagelijkse stadsgeluid uit het verleden en laat bovendien zien hoe tijd- en plaatsgebonden factoren het oordeel over die geluiden bepalen. De materiele veranderingen in geluid blijken niet alleen het gevolg te zijn van meer, minder of veranderende artefacten in de stad, maar ook van wijzigingen in het gebruik van de openbare ruimte. Vanaf het einde van de negentiende eeuw tot aan het uitbreken van de Tweede Wereldoorlog, neemt het verkeer in Amsterdam de straat geleidelijk in bezit. En dat gaat ten koste van straathandel, nijverheid, huiselijke karweitjes en andere vormen van straatleven. Het brede scala aan geluiden van deze laatste activiteiten worden daardoor allengs vervangen door het geluid van verkeersdeelnemers en de signalen die ze uitwisselen. Aan de hand van de casussen wordt bovendien duidelijk dat het stadsgeluid niet alleen in materiële zin verandert maar dat de betekenis van en opvattingen over geluid ook wijzigen.

Geluid en geschiedschrijving vormen een merkwaardig duo. Als het gaat om het oproepen van een ambiance wordt in historisch werk vaak gebruik gemaakt van geluid of van andere zintuiglijke ervaringen. Geert Mak begint Hoe God verdween uit Jorwerd, de biografie van een Friese boerensamenleving die eeuwenlang hetzelfde bleef totdat ze aan het eind van de negentiende eeuw overspoeld werd door de moderne tijd, met het noemen van de geluiden die niet meer gehoord worden in het dorp (Mak, 1997). En in Herfsttij der Middeleeuwen voert Huizinga het geluid van klokken op als een symbool voor de hele periode.

Er was één geluid, dat al het gedruisch van het drukke leven steeds weer overstemde, en dat, hoe bont dooreen-klinkend, toch nooit verward, alles tijdelijk ophief in een sfeer van orde: de klokken. De klokken waren in het dagelijksch leven als waarschuwende goede geesten, die met bekende stem dan rouw, dan blijdschap, dan rust, dan onrust kondigden, dan opriepen, dan vermaanden. Men kende hen bij gemeenzame namen: de dikke Jacqueline, klokke Roelant; men wist de beteekenis van kleppen of luiden. Men was ondanks het overmatig klokgelui niet verstompt voor den klank (Huizinga, 1919, p. 3).

In dit werk wordt geluid gebruikt als een middel om de lezer mee te voeren naar andere tijden maar het speelt in de analyse van de historische realiteit verder geen rol. Die situatie is sinds kort aan het veranderen als gevolg van nieuwe richtingen in zowel historisch onderzoek als stadsonderzoek in het algemeen. In de recent verschenen publicatie Greep op de stad: Nieuwe wendingen in het stadsonderzoek, betogen de auteurs dat de toenemende publieke belangstelling voor alles wat er zich binnen en rondom steden afspeelt dwingt tot het leggen van verbanden tussen persoonlijke ervaringen en de 'grotere' historische thema's (Taverne, Dembski, Klerk, \& Ramakers, 2012, pp. 10-11). Zij zien deze trend ook weerspiegeld in de stadsmusea van Amster- 
dam en Rotterdam, die meer aandacht proberen te geven aan de vraag: "hoe en door wie en wat zijn de dingen veranderd en met welke gevolgen voor wie?" (ibidem, p. 11). In die context past ook de klankinstallatie Het geluid van Amsterdam in het Amsterdam Museum, waarin gebruik is gemaakt van dit onderzoek naar het geluid van gisteren. ${ }^{175}$

De verbinding tussen 'kleine' en 'grote' geschiedenissen kan op uiteenlopende manieren worden gelegd. In het boek Streetlife: The Untold History of Europe's Twentieth Century bijvoorbeeld, wordt hieraan invulling gegeven door de straat te beschouwen als het toneel waarop de grote geschiedenis van historische figuren en de kleine geschiedenis van 'gewone' mensen samenkomen (Jerram, 2011, pp. 1-5). En de tussen 2004 en 2007 verschenen lijvige delen van de reeks Geschiedenis van Amsterdam bevatten naast een grote hoeveelheid prachtig beeldmateriaal, ook thematische hoofdstukken die bepaalde aspecten van het dagelijks leven belichten (Geschiedenis van Amsterdam, 2004).

Deze dissertatie gaat in op het geluid in het dagelijks leven van de stedeling tegen de achtergrond van industrialisering, technologisering en de Tweede Wereldoorlog. Dat zorgt niet alleen voor een verbinding van 'kleine' en 'grote' geschiedenis maar sluit ook aan bij het thema 'leefbaarheid van steden' dat in internationale context binnen de stadsgeschiedenis steeds meer aandacht krijgt (Blondé et al., 2012, p. 270). Daarbij biedt de systematische analyse van het geluid van één en dezelfde stad over meerdere periodes een goede aanvulling op publicaties als The City and the Senses (2007) en Senses and the City (2011) die niet alleen zijn samengesteld uit bijdragen vanuit uiteenlopende disciplines, maar bovendien betrekking hebben op diverse zintuiglijke ervaringen en op verschillende steden (Cowan \& Steward, 2007a; Diaconu, Heuberger, Mateus-Berr, \& Vosicky, 2011).

Naast de toegenomen belangstelling van historici voor de vele aspecten van het leven in de stad, vormt dit dagelijkse reilen en zeilen ook steeds vaker het vertrekpunt voor onderzoek naar de stad dat de monodisciplinaire perspectieven van bijvoorbeeld sociologen, economen, architecten en stedenbouwkundige vanaf de start wil integreren (Boomkens, 2013, p. 34). Een voorbeeld van deze trend is de oprichting - door universiteiten en andere onderzoeksinstituten - van zogenaamde 'Urban Labs' die in het onderzoek naar de historische en toekomstige stad disciplinaire grenzen en bestaande professionele praktijken nadrukkelijk proberen te doorsnijden en daarbij aan een grote variatie van aspecten - waaronder de zintuiglijke ervaring - aandacht besteden. ${ }^{176}$ Aan dit soort onderzoeken kan dit werk over het geluid van Amsterdam een bijdrage leveren, doordat het de tot voor kort primair visuele informatie over de stedelijke materialiteit aanvult en verrijkt en bovendien laat zien dat deze stedelijke 'materialiteit' in belangrijke mate bepaald wordt door sociale en culturele processen.

\footnotetext{
${ }^{175}$ Zie website http://amsterdammuseum.nl/het-geluid-van-amsterdam, geraadpleegd op 21 juni 2013.

${ }^{176}$ Zie bijvoorbeeld UCL Urban Laboratory, website http://www.ucl.ac.uk/urbanlab, geraadpleegd op 21 juni 2013.
} 
Als we vanuit deze belangstelling voor het stadsleven kijken naar de casussen over het geluid van Amsterdam, wordt duidelijk dat we de invloed van de toenmalige veranderingen op het dagelijks bestaan niet kunnen begrijpen vanuit het perspectief op de klankwereld waarin we zelf leven. Dit laatste is op zichzelf niet verrassend, want in dit onderzoek is uitgegaan van een definitie van het begrip 'soundscape' dat rekening houdt met zowel de geluiden in de leefomgeving als de manier waarop de mens betekenis geeft aan die geluiden (E. Thompson, 2002, p. 1). Maar juist door onze historische afstand krijgen we wel zicht op de 'eigenaardigheden' van situaties in het verleden. Zo verwachtte ik op grond van mijn eigen ervaringen met lawaai, die ongetwijfeld beïnvloed zijn door de aandacht voor het milieu sinds de jaren zeventig, dat aan het eind van de negentiende eeuw de toename van notoire 'herriemakers' als stoommachines, smederijen en koperslagers in de Amsterdamse binnenstad voor veel klachten en Hinderwetprocedures zou zorgen. Dat bleek echter helemaal niet het geval, waardoor ik oog kreeg voor het feit dat er wel relatief veel aandacht was voor en klachten over het geluid van stemmen en klokken.

Bij het 'overbruggen' van de afstand tot de historische soundscapes en de rol die ze speelden in het dagelijks leven, vormt het analytisch kader een belangrijk hulpmiddel. Door systematisch aandacht te besteden aan de materiële aspecten van het klanklandschap (ecologie van geluid), de problemen met geluid (politiek van geluid) en de betekenis (semiotiek van geluid) komen de specifieke historische relaties tussen deze verschillende aspecten van het stadsgeluid scherper in beeld. Dat reduceert de kans dat de historische teksten over het geluid begrepen worden vanuit onze huidige ervaringen en verwachtingen. Stilte bijvoorbeeld, heeft in het interbellum een heel andere betekenis dan in de daarop volgende oorlog, waardoor het begrijpelijk wordt dat het geluid van autoverkeer, waarover eerder werd geklaagd, in de oorlog node wordt gemist. En de toenemende klachten over het geluid van de buren tijdens het interbellum zijn niet het logische gevolg van een toenemende concentratie van de bevolking in de stad, maar hangen samen met het feit dat een groot deel van de bevolking nu voor het eerst in stille woonwijken woont.

Toepassing van het analytisch kader in samenhang met het gebruik van verzamelingen van gedigitaliseerde teksten heeft ook de verschuivingen in de betekenis van 'geluidswoorden' in beeld gebracht en de bijbehorende concepten en vanzelfsprekende uitgangspunten over geluid als natuurkundig verschijnsel. Bij het zoeken naar artikelen met behulp van woorden, bleken dezelfde termen bij kranten uit het einde van de negentiende eeuw resultaten op te leveren die qua inhoud niet te vergelijken waren met artikelen uit het interbellum. De woorden 'geluid' en 'lawaai' bijvoorbeeld werden in de eerste periode meestal gebruikt in de betekenis van 'stem' respectievelijk 'protest'. Daardoor hadden de artikelen waarin deze woorden voorkwamen, betrekking op een heel ander onderwerp dan artikelen uit het interbellum waarin deze woorden gebruikt werden in de betekenis die wij er ook nu nog aan toekennen. De veranderingen in de betekenis van woorden voor geluid, de gebruikte 
vergelijkingen en metaforen en de geluiden die het meest genoemd worden tonen aan dat er ook sprake was van een wezenlijk andere kijk op en verklaring voor het fenomeen geluid.

Tenslotte brengt de systematische analyse, in combinatie met de mogelijkheid van deze studie om tijdvakken te vergelijken, ook veranderingen aan het licht in het oordeel over bepaalde geluiden en hoe dat oordeel beïnvloed wordt door de wisselwerking tussen dagelijkse ervaringen en populaire 'waarheden' over mens en maatschappij. Aan het eind van de negentiende eeuw gaat daarom relatief veel aandacht uit naar het aanstootgevende geluid van de 'mindere klasse' en tijdens het interbellum zijn het vooral de geluiden van auto's en radio's in handen van de 'massa mens' die regelmatig terugkeren in het debat over stadsgeluid.

\section{Geluid, lawaai en stilte in stad en discours}

Ondanks gelijksoortige trends op het gebied van bevolkingsgroei, industrialisering en technologisering wordt in Amsterdam aan het eind van de negentiende eeuw veel minder over geluid geklaagd dan tijdens het interbellum. Er is dan weliswaar sprake van een grotere verkeersintensiteit en een grotere diversiteit van voertuigen en de snelheid waarmee deze zich verplaatsen, maar daar staat tegenover dat keienbestrating door asfalt is vervangen en ijzeren wielen door luchtbanden. Deze ontwikkelingen zorgen zeker voor een ander klanklandschap, maar er kan niet zonder meer geconcludeerd worden dat er altijd sprake is van een toename van geluidsbronnen, geluiden met een hoger volume of moeilijker te negeren geluiden. In tegenstelling tot de redenering die in de studies van Payer (Wenen 1870-1914), Saul (Duitse keizerrijk 18701914) en Smilor (1900-1930 Amerikaanse steden) wordt gevolgd, laat de vergelijking van de Amsterdamse casussen zien dat bevolkingsgroei, industrialisering en technologisering niet per definitie leiden tot 'meer' geluid en om die reden ook tot een toename van klachten over geluid (Payer, 2007; Saul, 1996b; Smilor, 1977). En de klachten die er zijn, hoeven bovendien niet rechtstreeks verband te houden met het geluid van meer mensen, machines en werkplaatsen.

We hebben dan ook gezien dat er in Amsterdam in de periode 1875 - 1895 opvallend weinig aandacht is voor het geluid van machines en nijverheid en relatief veel aandacht voor en klachten over het geluid van de stemmen en muziek van 'het gemeen' of 'die onmuzikale Nederlanders'. Anders dan de klachten van schrijvers, kunstenaars, filosofen en vergelijkbare professionals over straatmuziek in Londen tijdens de tweede helft van de negentiende eeuw, zijn de Amsterdamse klachten gericht tegen het stemgeluid en de muziek van 'het gemeen' als geheel en niet tegen een specifieke groep als straatmuzikanten of venters. Die aandacht voor stemmen en muziek hangt samen met het oudere paradigma van geluid dat muziek plaatst tegenover alle andere geluiden (niet-muziek) en met het feit dat in de negentiende-eeuwse 
standenmaatschappij 'het gemeen' niet geacht werd haar stem te verheffen. Een specifieke actie tegen straatmuzikanten van onder andere schrijvers en kunstenaars, zoals Picker die voor Londen beschrijft en verklaart, is er in Amsterdam echter niet (Picker, 2000).

De Amsterdamse casussen onderschrijven wel de uitkomst van Birkefelds en Jungs onderzoek naar de veranderingen in de openbare ruimte als gevolg van de motorisering van het verkeer en de elektrisering van Hannover in het begin van de twintigste eeuw (Birkefeld \& Jung, 1994). Uit de vergelijking van de tijdvakken blijkt echter ook dat de veranderingen in het oordeel over het geluid in de openbare ruimte niet alleen beïnvloed werden door een ander gebruik van die ruimte, maar ook door het feit dat een steeds groter deel van de bevolking onderdak vond in stillere buurten en comfortabelere woningen. De veranderingen in het gebruik van de ruimte als gevolg van een toename van verkeersdeelnemers, zowel in absolute aantallen als in variatie qua snelheid, maakte het geven van geluidsignalen noodzakelijk. Vervolgens zorgde de combinatie van veel signalen en relatief korte en nauwe Amsterdamse straten er voor dat het getoeter en gebel verwarring veroorzaakte en dus zijn doel voorbij schoot. Het getoeter werd een symbool in het gevecht om de straat, waardoor de verandering in het gebruik van de straat gekoppeld werd aan het oordeel over verkeersgeluid. In aanvulling op die situatie laten de Amsterdamse casussen zien dat de toename van klachten over stadsgeluid, met de nadruk op het geluid van verkeer en de buren, ook te maken had met het feit dat steeds meer stadsbewoners gewend raakten aan stilte in en om de woning.

Net zoals in Amsterdam aan het einde van de negentiende eeuw geen groep van schrijvers of andere professionals te vinden is die actie voert tegen straatmuzikanten, kunnen in het interbellum oordelen en klachten over geluid evenmin worden teruggebracht tot een dominant discours dat, zoals in New York, gerelateerd kan worden aan bepaalde gezaghebbende persoonlijkheden in de stedelijke samenleving (Radovac, 2011). De klachten kunnen echter wel worden ondergebracht in een aantal clusters van bij elkaar horende meningen, motieven en interventies. Tussen deze clusters kunnen weliswaar geen scherpe scheidingslijnen worden getrokken omdat ze elkaar onderling beïnvloeden en soms overlappen, maar er zijn wel zwaartepunten aanwijsbaar. Zo kan er onderscheid worden gemaakt in (a) een cluster over het geluid van venters en straatmuzikanten waarbij economische motieven een rol spelen; (b) een cluster dat zich richt op autogetoeter en verkeersveiligheid en de strijd om het gebruik van de straat; (c) een cluster rondom geluid in woonwijken waarin veel stedelingen voor het eerst met een relatief stille woonomgeving te maken krijgen en (d) een cluster over stadsgeluid en lawaai als onderwerp voor onderzoek en interventie door 'professionals'.

De onderverdeling in clusters helpt om problemen rondom geluid op microniveau in een sociale context te zetten, maar de overlap en wisselwerking tussen de clusters laten ook zien dat 'geluidshinder' zelden te relateren is aan één specifieke bron van 
geluid. Zo kan de discussie over hinder van radio's niet helemaal los worden gezien van het discours over autogetoeter en hangen klachten over het geluid van venters in de binnenstad ook samen met verkeershinder en het gevecht om het gebruik van de straat. De beleving van een bepaald geluid wordt niet alleen beïnvloed door het dominante discours over dat geluid, zoals Christian Bröer aantoont in zijn onderzoek naar het verband tussen de hinder van het geluid van vliegtuigen en de strekking van het beleid over dat onderwerp (Bröer, 2006), maar ook door de associatie met andere (omstreden) geluiden. De verspreiding van auto's en radio's neemt tijdens het interbellum een grote vlucht, waardoor het geluid van deze relatief nieuwe maar verder totaal verschillende apparaten toch samen een hoofdrol spelen in klachten van de stedeling. Ze benemen hem immers "het genoegen van het leven, dat in de groote stad toch al zeer twijfelachtig is, in ieder geval de rust, waarnaar hij na zijn dagelijkschen arbeid haakt." ${ }^{177}$

Om het voorgaande in een breder kader te plaatsten staan we tenslotte stil bij het actuele discours over geluidsoverlast, aan de hand van de volgende beknopte analyse van recente krantenartikelen. Het gaat om artikelen uit Het Parool en De Telegraaf uit de periode 1 april 2011 tot 1 april 2012 waarin het woord 'geluidsoverlast' minimaal één keer voor komt en die enigszins te relateren zijn aan Amsterdam. Het merendeel van de teksten gaat over concrete vormen van overlast waarover wordt geklaagd, maar er zijn ook artikelen die betrekking hebben op het voorkómen van geluidsoverlast of op situaties waarin voor de overlast een oplossing is gevonden. ${ }^{178}$ In deze teksten zorgt geluid voor stress, slaapproblemen, cardiovasculaire effecten en leer- en leesachterstanden bij kinderen. Het put mensen uit, maakt ze ziek en verkort hun leven. Geluidsoverlast wordt uitgedrukt in levensjaren die verloren gaan, in ontwikkelingsachterstanden van kinderen en in het niet kunnen gebruiken van delen van de woning. Niet kunnen werken of gedwongen worden om te verhuizen zorgt voor kosten in de privé sfeer, terwijl de samenleving moet opdraaien voor hoge zorglasten en kosten in verband met de inzet van politie en ambtenaren.

In onze eigen tijd worden klachten over geluid niet meer verbonden met de aantasting van orde en fatsoen door de rafelrand van de maatschappij of met overprikkeling van het zenuwgestel van de stadsbewoner als gevolg van het onverantwoorde gedrag van de mateloze massamens, maar met blootstelling aan ziekmakende en achterstand veroorzakende invloeden die hoge kosten met zich meebrengen. Ik beschrijf en vergelijk deze voorbeelden niet om de hedendaagse perceptie van geluidsoverlast af te doen als overdreven noch om ze te bestempelen als de enig juiste

\footnotetext{
177 'Minder straatlawaai!', Algemeen Handelsblad, 13-08-1928.

${ }^{178}$ Het gaat in om 17 artikelen in Het Parool en 11 in De Telegraaf uit een totaal van 159 artikelen die het woord 'geluidsoverlast' bevatten (waarvan 100 afkomstig uit De Telegraaf). De helft van de artikelen gaat over geluidoverlast op een specifieke locatie, een bepaalde horecagelegenheid, bouwput of buurt. De andere helft gaat over overlast van allerlei verschillende geluiden of overlast die niet aan een bepaalde locatie verbonden is.
} 
manier om de nadelige effecten van geluid kenbaar te maken. De vergelijking van de klachten over geluid uit het einde van de negentiende eeuw, het interbellum en onze eigen tijd is interessant omdat ze laat zien dat in elke periode een beperkt aantal geluiden symbool staat voor of geassocieerd wordt met de overwegend abstracte en onbeheersbare bedreigingen en gevaren van dat moment. Zoals de stemmen van de onderklasse die de regels van goed fatsoen aan haar laars lapt en een gevaar vormt voor de gevestigde orde, het geblèr van de radio dat een teken is van de verloedering van kunst en cultuur of de door onszelf gecreëerde verkeers- en andere omgevingsgeluiden die het leven verkorten, achterstand veroorzaken en veel geld kosten.

Vergelijken we de voorgaande casussen met de Tweede Wereldoorlog, dan valt op dat in de laatste periode geen specifieke geluiden maar juist stilte deze symbolische functie vervult. Stilte vanwege het ontbreken van stadsgeluiden uit betere tijden of stilte die de onzekerheid van het moment benadrukt (niet weten wat er komen gaat) staat in deze periode symbool voor gevaar en dreiging. Eerder hebben we ook gezien dat de betekenis van geluiden tijdens de Tweede Wereldoorlog sterk veranderde en dat het kunnen omgaan met typische oorlogsgeluiden (van overvliegende bommenwerpers, afweergeschut en luchtalarm) afhankelijk was van de mate waarin men deze geluiden in de gewijzigde context kon plaatsen.

Deze dissertatie heeft aangetoond dat er in de loop van 140 jaar veel veranderd is in het geluid van de stad, maar het is niet mogelijk om die veranderingen te vertalen naar meer of minder stilte in Amsterdam. Elke tijd heeft eigen geluiden, eigen woorden om die geluiden te beschrijven, eigen uitdrukkingsmechanismen voor klachten en eigen opvattingen over stilte. Stilte kan een beklemmend oorlogsgeluid zijn en tegelijkertijd symbool staan voor het gemis aan betere tijden toen er nog volop 'leven' was in de stad. Allen al om die reden was Amsterdam vroeger ook niet stil. Uitspraken dat steden almaar lawaaiiger worden of dat het geluid in de stad almaar 'erger' wordt, zoals verwoord in het citaat van Hofland aan het begin van dit boek, moeten dan ook vooral begrepen worden als retorische strategieën die samenhangen met gevoelens van onbehagen over de eigen tijd. 


\section{Bijlage: Overzicht primaire bronnen}

\section{Archieven}

Archief Anti-lawaai comité Groningen, map 'Brieven op Persberichten' 1935-1937; beschikbaar gesteld door Hero Wit en in het bezit van Maastricht University, Faculty of Arts \& Social Sciences.

NIOD, Instituut voor Oorlogs-, Holocaust- en Genocidestudies, egodocumenten.

Stadsarchief Amsterdam

Archief Secretarie Publieke Werken Amsterdam (toegangsnummer 5180)

Archief van de Politie (toegangsnummer 5225)

Archief van het Bureau voor Statistiek (toegangsnummer 5185)

Gemeenteblad (bibliotheek)

Persdocumentatie Collectie Stadsarchief Amsterdam (toegangsnummer 30486).

\section{Databanken}

Archief Leeuwarder Courant, http://www.archiefleeuwardercourant.nl/index.do Het Illegale Parool, http://www.hetillegaleparool.nl/ Historisch Archief van De Groene Amsterdammer, http://www.groene.nl/historisch Historische Kranten Koninklijke Bibliotheek, http://kranten.kb.nl/ Krantenbank Openbare Bibliotheken http://zoeken.bibliotheek.nl/?exact=Krantenbank

\section{Dagboeken}

Dagboek Anoniem, NIOD archief 244, nr. 1419

Dagboek Anoniem, Wim, NIOD archief 244, nr. 1164

Dagboek van den Berg, NIOD archief 244, nr. 1264

Dagboek Beuth, NIOD archief 244, nr. 1134

Dagboek Blitz, NIOD archief 244, nr. 1242

Dagboek Bruijn - Barends, NIOD archief 244, nr. 1151

Dagboek van Buuren, NIOD archief 244, nr. 1230

Dagboek Cox, NIOD archief 244, nr. 1082

Dagboek van der Does, NIOD archief 244, nr. 1179

Dagboek van Donkelaar, NIOD archief 244, nr. 1570 
Dagboek Gerlagh, NIOD archief 244, nr. 1539

Dagboek Goudsmit, NIOD archief 244, nr. 1205

Dagboek Hanemann - Keleman, NIOD archief 244, nr. 1133

Dagboek Hemsing, NIOD archief 244, nr. 1225

Dagboek Herks, NIOD archief 244, nr. 1129

Dagboek Hirschel, NIOD archief 244, nr. 1433

Dagboek Koekenheim, NIOD archief 244, nr. 1208

Dagboek Koekenheim - Voet, NIOD archief 244, nr. 1208

Dagboek Koopman, NIOD archief 244, nr. 1160

Dagboek Korting, NIOD archief 244, nr. 1456

Dagboek Lans - Van der Wal, NIOD archief 244, nr. 1092

Dagboek Luthart, NIOD archief 244, nr. 1313

Dagboek Meents, NIOD archief 244, nr. 1136

Dagboek Polak, NIOD archief 244, nr. 1131

Dagboek Roos - van Rossem, NIOD archief 244, nr. 1513

Dagboek Sander, NIOD archief 244, nr. 1141

Dagboek Spruit - Duis, NIOD archief 244, nr. 1186

Dagboek Verwey, NIOD archief 244, nr. 1187

Dagboek Anne Frank, Frank, A., \& Frank, O. (2008). Het Achterhuis: dagboekbrieven

12 juni 1942-1 augustus 1944 (48e dr. ed.). Amsterdam: Bakker.

Dagboek Bolle, Bolle, M., \& Houwink ten Cate, J. (2003). Ik zal je beschrijven hoe een dag er hier uitziet: dagboekbrieven uit Amsterdam, Westerbork en Bergen-Belsen. Amsterdam etc.: Contact. 


\section{Lijst van afbeeldingen}

Afbeelding 1: $\quad$ Artikelen uit de periode 1875-1895.

Afbeelding 2: Dam ca 1890. Bron: Beeldbank Stadsarchief Amsterdam, afbeeldingsnummer 010003005950.

Afbeelding 3: Jodenbreestraat 1886. Bron: Beeldbank Stadsarchief Amsterdam, afbeeldingsnummer 010005001609.

Afbeelding 4: "Veel handen maken ligt werk" niet gedateerd. Bron: Beeldbank Stadsarchief Amsterdam, afbeeldingsnummer 010097005529.

Afbeelding 5: $\quad$ Telefoonmasten op de Prins Hendrikkade ca 1890. Bron: Beeldbank Stadsarchief Amsterdam, afbeeldingsnummer 010005000557.

Afbeelding 6: "Uitwerking van een polka door het orkest te Buiksloot", tekening (ca 1883) uit het Humoristisch Album. Bron: Atlas van Stolk, Rotterdam.

Afbeelding 7: $\quad$ Verkeer in de Leidsestraat ca 1929. Bron: Beeldbank Stadsarchief Amsterdam, afbeeldingsnummer 010003010250.

Afbeelding 8: $\quad$ Sluitzegelactie Veilig Verkeer, tekening door G. J. J. Verbeek. Bron: Algemeen Handelsblad, 18-4-1928.

Afbeelding 9: $\quad$ Rateljongen ca 1920. Bron: Beeldbank Stadsarchief Amsterdam.

Afbeelding 10: "De Radio van de Buren", tekening door Charles Boost. Bron: De Groene Amsterdammer, 09-03-1940. Met dank aan Rolf Boost.

Afbeelding 11: Heien op het Daniël Willinkplein 1930. Bron: Beeldbank Stadsarchief Amsterdam, afbeeldingsnummer 010003020962.

Afbeelding 12: Voorbeelden van campagnes en artikelen ter verbetering van het gedrag in het verkeer. Boven: Verkeers-Offensief, tekening door Bernard van Vlijmen. Bron: Algemeen Handelsblad, 26-10-1925.

Beneden links: Auto-Muziek, Meer Stilte. Bron Het Vaderland 3009-1933. Met dank aan de ANWB. Beneden rechts: De strijd tegen het lawaai: vragen van verkeer. Bron: Algemeen Handelsblad, 1907-1934.

Afbeelding 13: "Rumoerbestrijding" tekening door George van Raemdonck. Bron: De Groene Amsterdammer, 16-06-1923. Met dank aan Cathy van Bauwel - Collet.

Afbeelding 14: Paardentaxi's op de Dam, 1940-1945, foto door Ad Windig. Bron: Maria Austria Instituut, afbeeldingsnummer 010004000154.

Afbeelding 15: Verkoop van fietsen zonder banden op het Waterlooplein, 19401945, foto door Ad Windig. Bron: Maria Austria Instituut, afbeeldingsnummer 010004000152. 
Afbeelding 16: Heimelijk gemaakte opname van een Duitse militaire parade, foto door Jacobus Hofman. Bron: Beeldbank Stadsarchief Amsterdam, afbeeldingsnummer HOFM0100513000001. Met dank aan Jaap Hofman.

Afbeelding 17: Parade van Duitse soldaten op de Dam, februari 1941. Bron: Beeldbank Stadsarchief Amsterdam, afbeeldingsnummer 010003042689.

Waar mogelijk zijn de rechten van bovenstaande illustraties geregeld via de daarvoor geldende bepalingen. Het is echter niet gelukt om te achterhalen wie over de rechten op het werk van Bernard van Vlijmen en van G. J. J. Verbeek beschikt. Voor vragen en opmerkingen kunt u contact opnemen met de auteur. 


\section{Bibliografie}

Amsterdammer, E., \& Gouw, J. t. (1875/1974). Amsterdam en de Amsterdammers. Amsterdam: Vereniging vrienden van het Amsterdam-boek.

Anders, F. (Producer). (2010, October 21, 2011). Weg met de Vlootwet! geschiedenis.nl. Retrieved from http://www.geschiedenis.nl/index.php?go=home.showBericht\&bericht_id=3316

Anderson, I. (2012). Voice, Narrative, Place: Listening to Stories. Journal of Sonic Studies, 2(1). Retrieved from http://journal.sonicstudies.org/vol02/nr01/a10

Anoniem. (1887/1981/2008). De arbeidsenquête van 1887/Een kwaad leven. Deel 1: Amsterdam In J. Giele (Ed.), De arbeidsenquête van 1887. Nijmegen: Uitgeverij Link. Retrieved from http://www.dbnl.org/tekst/_arb001jgie01_01/_arb001jgie01_01_0002.php.

Arkette, S. (2004). Sounds Like City. Theory, Culture \& Society, 21(1), 159-168.

Atkinson, R. (2007). Ecology of Sound: The Sonic Order of Urban Space. Urban Studies, 44(10), 1905-1917.

Bailey, P. (1998/2004). Breaking the Sound Barrier. In M. M. Smith (Ed.), Hearing History: A Reader. Athens and London: The University of Georgia Press.

Bain, M. (2005). Psychosonica en de modulatie van de publieke ruimte: Over subversieve sonische tehnieken. Open: Cahier over kunst en het publieke domein, 4(9), 94-109.

Bandt, R., Duffy, M., \& MacKinnon, D. (Eds.). (2009). Hearing Places: Sound, Place, Time and Culture. Newcastle upon Tyne: Cambridge Scholars Publishing.

Batelt, C. (1912). Duister Amsterdam (2e geh. omgew. en verm. dr. ed.). Amsterdam: Allert de Lange.

Bijsterveld, K. (2001). The Diabolical Symphony of the Mechanical Age: Technology and Symbolism of Sound in European and North American Noise Abatement Campaigns, 1900-40. Social studies of science : an international review of research in the social dimensions of science and technology, ISSN 0306-3127, 31(1), 37 (34).

Bijsterveld, K. (2003). "The City Of Din": Decibels, Noise, and Neighbors in the Netherlands, 1910-1980. In S. Dierig, J. Lachmund \& J. A. Mendelsohn (Eds.), Science and the City. Chicago, IL: The University of Chicago Press.

Bijsterveld, K. (2008). Mechanical Sound: Technology, Culture, and Public Problems of Noise in the Twentieth Century. Cambridge, MA etc.: MIT Press.

Bijsterveld, K., Jacobs, A., Aalbers, J., \& Fickers, A. (2013). Shifting Sounds: Textualization and Dramatization of Urban Soundscapes. In K. Bijsterveld (Ed.), Soundscapes of the Urban Past: Staged Sound as Mediated Cultural Heritage. Bielefeld: Transcript Verlag.

Birdsall, C. (2010). Between Noise and Silence: Sound, Technology and Urban Space during Nazi Germany. PhD, University of Amsterdam, Amsterdam.

Birkefeld, R., \& Jung, M. (1994). Die Stadt, Der Larm und das Licht: die Veranderungen des offentlichen Raumes durch Motorisierung und Elektifizierung. Seelze (Velber): Kallmeyer.

Bloemgarten, S. (2003). Een joodse straat in de Rivierenbuurt. In M. Polak, Sander \& G. v. Herwijnen (Eds.), Wim Polak: Amsterdammer en sociaal-democraat. Amsterdam: Meulenhoff.

Blondé, B., Greefs, H., Puttevils, J., Stabel, P., Tritsmans, B., \& Van Damme, I. (2012). Stadsgeschiedenis in meervoud: Impressies van de internationale stadshistorische conferenties in Praag en New York, 2012. Stadsgeschiedenis, 7(2), 262-280.

Boer, J. F. M. d., \& Duparc, S. (1948). Kroniek van Amsterdam over de jaren 1940-1945. Amsterdam: De Bussy; Genootschap Amstelodamum.

Boers, J., \& Bosveld, W. (2005). Geluidshinder in Amsterdam: enquete onder de bevolking. Amsterdam: Gemeente Amsterdam, Dienst Onderzoek en Statistiek.

Bolle, M. (2003). Ik zal je beschrijven hoe een dag er hier uitziet : Dagboekbrieven uit Amsterdam, Westerbork en Bergen-Belsen. Amsterdam etc.: Contact/Pandora.

Boom, B. v. d. (2003). 'We leven nog': de stemming in bezet Nederland. Amsterdam: Boom. 
Boomkens, R. (2013). Mediacity: On the Discontinious Continuity of the Urban Public Sphere. In J. Thissen, R. Zwijnenberg \& K. Zijlmans (Eds.), Contemporary Culture: New Directions in Arts \& Humanities Research (pp. 9-36). Amsterdam: Amsterdam University Press.

Boterman, F. (2003). Inleiding. In F. Boterman \& M. Vogel (Eds.), Nederland en Duitsland in het interbellum (pp. 7-19). Hilversum: Ultgeverij Verloren.

Braeckman, A., Bauer, R., \& De Visscher, J. (Eds.). (2001). Onbehagen met de moderniteit: De revolte van de intellectuelen 1890 -1933. Kapellen: Uitgeverij Pelckmans.

Bregstein, P., \& Bloemgarten, S. (2004). Herinneringen aan Joods Amsterdam (3 ed.). Amsterdam: De Bezige Bij.

Brink, J. (1929, 03-03-1929). Radio-leed, Algemeen Handelsblad.

Bröer, C. (2006). Beleid vormt overlast : hoe beleidsdiscoursen de beleving van geluid bepalen. Amsterdam: Aksant.

Broersma, M. (2001). Het digitale verleden en de toekomst van de mediageschiedenis. Tijdschrift voor Mediageschiedenis, 2011(2), 4-9.

Broersma, M. (2002). Beschaafde vooruitgang : de wereld van de Leeuwarder Courant 1752-2002. Leeuwarden: Friese Pers Boekerij.

Broersma, M. (2010). Diep in de billen van de samenleving. Geschiedenis van "De Telegraaf". Ons erfdeel: Vlaams-Nederlands cultureel tijdschrift, 53(2), 174-176.

Broersma, M. (2011). Nooit meer bladeren? Digitale krantenarchieven als bron. Tijdschrift voor Mediageschiedenis, 2011(2), 29-55.

Bronzwaer, S., \& Koning, P. d. (2011, August 4, 2011). Zijn Nederlandse kinderen ook zo lawaaiig?, NRCNEXT, p. 3.

Bruin, K., \& Schijf, H. (1984). De eerste bewoners in een deftige straat. In M. Jonker, L. Noordegraaf \& M. Wagenaar (Eds.), Van stadskern tot stadsgewest : stedebouwkundige geschiedenis van Amsterdam (pp. 133-156). Amsterdam: Verloren.

Buiter, H. (2005). Riool, rails en asfalt : 80 jaar straatrumoer in 4 Nederlandse steden. Zutphen: Walburg Pers.

Bull, M., \& Back, L. (2003). The auditory culture reader. Oxford etc.: Berg.

Campbell, G. J. (2000). "A Higher Mission Than Merely to Please the Ear": Music and Social Reform in America, 1900-1925. The Musical Quarterly, 84(2), 259-286. Retrieved from http://mq.oxfordjournals.org/content/84/2/259.short

Cate, C. L. t. (1975). Tot glorie der gerechtigheid : de geschiedenis van het brandmerken als lijfstraf in Nederland. Amsterdam: Wetenschappelijke Uitgeverij.

Chickering, R. (2007). The Great War and Urban Life in Germany: Freiburg, 1914-1918. Cambridge: Cambridge University Press.

Classen, C. (2001). The Senses. In P. N. Stearns (Ed.), Encyclopedia of European social history from 1350 to 2000 (Vol. IV, pp. 356-357). Detroit [etc.]: Scribner's Sons.

Coates, P. A. (2005). The strange Stillness Of The Past: Toward An Environmental History Of Sound And Noise. Environmental History, 10(4), 636-666. Retrieved from http://www.historycooperative.org/journals/eh/10.4/coates.html

Corbin, A. (1995). Time, desire and horror : towards a history of the senses (J. Birrell, Trans.). Cambridge etc.: Polity Press.

Corbin, A. (1998). Village Bells: Sound and Meaning in the Nineteenth-century French Countryside. New York: Columbia University Press.

Coster, C. D., \& Janson, K. J. A. (ca 1879/1998). Zijn vrouw zet bloedzuigers : de zeer persoonlijke indrukken van een reis, in 1877 ondernomen naar Amsterdam, Zaandam, Broek in Waterland, Monnikendam, Volendam, Hoorn, Scheveningen, Marken en Urk (3e dr. ed.). Amsterdam: Wereldbibliotheek.

Cowan, A., \& Steward, J. (2007a). The city and the senses : urban culture since 1500. Aldershot etc.: Ashgate.

Cowan, A., \& Steward, J. (2007b). Introduction. In A. Cowan \& J. Steward (Eds.), The city and the senses : urban culture since 1500 (pp. 1-22). Aldershot etc.: Ashgate.

Crook, T. (2012). The Sound Handbook. London and New York: Routledge. 
Dam, W. J. v. (1888). Burengerucht. 's-Hertogenbosch: Van Heusden.

De Amicis, E., Lodeesen, D., \& Fagel, R. (1876/1985). Nederland en zijn bewoners. Utrecht etc.: Veen.

de Vries, J. D. (1844). Physiologie van Amsterdam, door Een' Amsterdammer. Amsterdam: Leepel \& Brat.

Dekker, M. (1937). Amsterdam. Amsterdam: N.V. EM. Querido's Uitgevers-Maatschappij.

Den Tex, U. (2009). Erfgenamen: Het verhaal van een Nederlandse familie van aanzien en vermogen. Amsterdam: Uitgeverij Balans.

Derks, M. (1991). Steps, shimmies en de wulpse tango. Dansvermaak in het interbellum. Spiegel historael: maandblad voor geschiedenis en archeologie, 26, 388-396, 414-415.

Diaconu, M., Heuberger, E., Mateus-Berr, R., \& Vosicky, L. M. (Eds.). (2011). Senses and the City: An Interdisciplinary Approach to Urban Sensescapes. Münster: LIT Verlag.

Dijk, M. v. (1981). Het beleid van de Amsterdamse overheid ten aanzien van straatmuzikanten 1900-1980. Volkskundig Bulletin, 7(2), 143-158.

Dijkhuis, H. (1939). Vijftig dagen in een Jordaans kosthuis. Amsterdam: N.V. J. Emmering's Uitgeverij.

Dubois, A. (1932, 08-05-1932). Acoustiek en moderne bouwkunde: De strijd tegen het lawaai., Algemeen Handelsblad, p. 27.

Eijk, P. v. d. (2008). Vodduh! : venters en hun straatroep. 's-Gravenhage: BZZTôH.

Encke, J. (2006). Augenblicke der Gefahr: Der Krieg und die Sinne. München: Wilhelm Fink Verlag.

Fortuin, H. B. (1940). De Radio van de buren: Critische verzuchting over een nationaal kwaad, dat zich snel uitbreidt. De Groene Amsterdammer.

Frank, A., \& Frank, O. (2008). Het Achterhuis : dagboekbrieven 12 juni 1942-1 augustus 1944 (48e dr. ed.). Amsterdam: Bakker.

Frank, A., \& Frank, O. (2009). Het Achterhuis : dagboekbrieven 12 juni 1942-1 augustus 1944 (55e dr. ed.). Amsterdam: Prometheus.

Garms, J. H. (1909). Over straatuitroepen en primitieve muziek. Tijdschrift voor Nederlandse Muziekgeschiedenis, IX(1).

Garrioch, D. (2003). Sounds of the city: the soundscape of early modern European towns. Urban history, ISSN 0963-9268, 30(1), 5-25 (21).

Geschiedenis van Amsterdam. (2004). Amsterdam: SUN.

Gitelman, L. (1999). Scripts, grooves, and writing machines : representing technology in the Edison era. Stanford, CA: Stanford University Press.

Goodale, G. (2011). Sonic Persuasion: Reading Sound in the Recorded Age. Urbana, Chicago, and Springfield: University of Illinois Press.

Goodman, D. (2010). Distracted Listening: On Not Making Sound Choises in the 1930s. In D. Suisman \& S. Strasser (Eds.), Sound in the Age of Mechanical Reproduction (pp. 15-46). Philadelphia: University of Pennsylvania Press.

Goodman, S. (2010). Sonic Warfare: Sound, Affect, and the Ecology of Fear. Cambridge Massachusetts, London: The MIT Press.

Gram, J. (1893). 's-Gravenhage in onzen tijd Amsterdam: J.L. Beijers.

Groot, G., de. (1988). 'Door slapte gedaan gekregen': losse arbeiders en hun gezinnen in Amsterdam tussen 1880 en 1920. Tijdschrift voor Sociale Geschiedenis, 14(2).

Hacohen, S. (1990). Zwijgende stenen : herinnering aan een vermoorde jeugd (A. Michael, Trans.). 'sGravenhage: BZZTôH.

Hajer, M. (1995). The Politics of Environmental Discourse: Ecological Modernization and the Policy Process. Oxford: Clarendon Press.

Hajer, M., \& Versteeg, W. (2005). A decade of discourse analysis of environmental politics: Achievements, challenges, perspectives. Journal of Environmental Policy \& PLanning, 7(3), 175-184. Retrieved from http://dx.doi.org/10.1080/15239080500339646

Hall, T. (1986). Planung europäischer Hauptstädte: zur Entwicklung des Städtebaues im 19. Jahrhundert. Stockholm: Almqvist \& Wiksell. 
Hard, M., \& Misa, T. J. (2008). Modernizing European Cities: Technological Uniformity and Cultural Distinction. In M. Hard \& T. J. Misa (Eds.), Urban machinery : inside modern European cities. Cambridge, MA. etc.: The MIT Press.

Hartmans, R. (2002). De Groene van 1877: geschiedenis van een dwars weekblad. Amsterdam: Mets \& Schilt. Havard, H. (1876). Amsterdam Et Venise. Paris: Plon.

Heertje, H. (1936). De diamantbewerkers van Amsterdam. Amsterdam: D.B. Centen's UitgeversMaatschappij N.V.

Heinemeijer, W. F. (1987). Amsterdam in kaarten : verandering van de stad in vier eeuwen cartografie. Ede etc.: Zomer \& Keuning.

Hendy, D. (2013). Noise: A Human History of Sound and Listening. London: Profile Books LTD.

Hoegaerts, J. (2010). A Manly People Should Dare to Sing Manly: Spaces and Sounds of Masculinity in a Nineteenth-Century Nation. Dissertation. Research Unit Modernity and Society, 1800-2000. University of Leuven, Faculty of Arts, Subfaculty of History. Leuven.

Hoekveld, G. A. (1964). Baarn : schets van de ontwikkeling van een villadorp = An inquiry into some developmental aspects of a metropolitan residential settlement. Baarn: Bosch \& Keuning.

Hoen, P. t. (1940, October 16). Het Deutschtum en de orgeldraaier. Nieuwsbrief 11. Retrieved March 17, 2010, from http://www.hetillegaleparool.nl/

Hofland, H. J. A. (2010). Oud geluid. In H. J. A. Hofland, G. Mak \& B. Blokker (Eds.), De kronieken van S. Montag: Nederland 1975-2010 (pp. 75-77). Amsterdam: De Bezige Bij.

Hofland, H. J. A. (2011, 18-06-2011). Lawaai; Overpeinzingen 1605, NRC Handelsblad, p. 37.

Hooper, G., \& Youngs, T. (Eds.). (2004). Perspectives on Travel Writing (Vol. 19). Aldershot [etc.] Ashgate.

Huberts, V. R. A. D. (1940). De Amsterdamse venters : een sociografische monografie. Amsterdam: Van Campen.

Huizinga, J. (1919). Herfsttij der Middeleeuwen : studie over levens- en gedachtenvormen der veertiende en vijftiende eeuw in Frankrijk en de Nederlanden. Haarlem: H.D. Tjeenk Willink.

Hulst, H. v., Pleysier, A., \& Scheffer, A. (1969). Het roode vaandel volgen wij : geschiedenis van de Sociaal Democratische Arbeiderspartij van 1880 tot 1940. \&apos;s-Gravenhage: Kruseman.

Jager, I. (2002). Hoofdstad in gebreke : manoeuvreren met publieke werken in Amsterdam 1851-1901. Rotterdam: Uitgeverij 010.

Jay, M. (2011). In the Realm of the Senses: An Introduction. The American historical review, 116(2), 307-316.

Jerram, L. (2011). Streetlife: The Untold History of Europe's Twentieth Century. Oxford: Oxford University Press.

Jonckers Nieboer, J. H. (1938). Geschiedenis der Nederlandsche Spoorwegen. Rotterdam: Nijgh \& van Ditmar N.V.

Jong, A., Michiel de. (ca. 1920). Amsterdam bij nacht: snelkieken van de "Leven"-redacteuren en teekeningen van Jordaan. Amsterdam.

Kaal, H. (2005). Verderfelijk vermaak: Het film-, toneel- en dansbeleid van de burgemeesters van Amsterdam, Rotterdam en Den Haag tijdens de roaring twenties. Holland: regionaal-historisch tijdschrift, 37(4), 259-277.

Kelman, A. Y. (2010). Rethinking the Soundscape: A Critical Genealogy of a Key Term in Sound Studies. The Senses and Society, 5(2), 23.

Klerk, L. d. (2008). De modernisering van de stad 1850-1914: de opkomst van de planmatige stadsontwikkeling in Nederland. Rotterdam: NAl uitgevers.

Klijn, E. (2011). Van 'oud' geheugen naar digitaal brein: Massadigitalisering in de praktijk. Tijdschrift voor Mediageschiedenis, 2011(2), 56-68.

Kluytenaar, H. A. (1936). Amsterdam en zijn bewoners in de 70, 80er jaren van de vorige eeuw. Jaarboek Amstelodamum, 33, 249-261.

Knotter, A. (1991). Economische transformatie en stedelijke arbeidsmarkt: Amsterdam in de tweede helft van de negentiende eeuw. Zwolle, Amsterdam: Waanders ;Gemeentearchief.

Kolfschooten, F. v. (2002). De koningin van Plan Zuid : geschiedenissen uit de Beethovenstraat (5e, geactualiseerde dr. ed.). Amsterdam etc.: Veen. 
Kooij, P. (1985). Stad en platteland. In F. L. v. Holthoorn (Ed.), De Nederlandse samenleving sinds 1815: wording en samenhang (pp. 93-115). Assen/Maastricht: Van Gorcum.

Langford, R., \& West, R. (1999). Marginal voices, marginal forms : diaries in European literature and history. Amsterdam etc.: Rodopi.

Lees, A. (1985). Cities perceived : urban society in European and American thought, 1820-1940. Manchester: Manchester University Press.

Lente, D. v. (1998). Dutch Conflicts: The Intellectual and Practical Appropriation of a Foreign Technology. In M. Hard \& A. Jamison (Eds.), The Intellectual Appropriation of Technology: Discourses on Modernity, 1900-1939. Cambridge (MA): MIT Press.

Leviticus, F., \& Polak, H. (1908). Geillustreerde Encyclopaedie der Diamantnijverheid. Haarlem: De Erven F. Bohn.

Loseke, D. R. (1999). Thinking About Social Problems: An Introduction to Constructionist Perspectives. New York: Aldine De Gruyter.

Lynch, M., \& Woolgar, S. (Eds.). (1990). Representation in Scientific Practice. Cambridge (MA): MIT Press.

Maier, R. (Ed.). (2011). Akustisches Gedächtnis und Zweiter Weltkrieg. Göttingen: V\&R unipress.

Mak, G. (1997). Hoe God verdween uit Jorwerd (6 ed.). Amsterdam: Atlas.

Mak, G. (2007). Een kleine geschiedenis van Amsterdam (33e druk ed.). Amsterdam etc.: Atlas.

Maurik, J. v. (1887/1901). Toen ik nog jong was Retrieved from http://www.dbnl.org/tekst/maur005toen01_01/colofon.php

Maurik, J. v. (ca 1890). Amsterdam bij dag en nacht : novellen en schetsen. Amsterdam: Van Holkema \& Warendorf.

Meere, J., M.,M., de. (1979). Inkomensgroei en -ongelijkheid te Amsterdam 1877-1940. Tijdschrift voor Sociale Geschiedenis, 5(13).

Meershoek, G. (2007). Onder nationaal-socialistisch bewind. In P. d. Rooy, D. Bosscher, S. Bloemgarten \& M. Carasso-Kok (Eds.), Geschiedenis van Amsterdam: tweestrijd om de hoofdstad 1900-2000 (pp. 235321). Amsterdam: SUN.

Mom, G. (1997). Geschiedenis van de auto van morgen. Deventer: Kluwer Bedrijfsinformatie BV.

Montijn, I. (1983). Kermis van koophandel : De Amsterdamse wereldtentoonstelling van 1883. Bussum: Van Holkema \& Warendorf.

Olie, J. (2007). De mooiste foto's van Amsterdam 1860-1905: Deel 1 - Van IJ tot Amstel; Deel 2 - Van Zandhoek tot Bijlmermeer. Amsterdam: Uitgeverij De Verbeelding.

Ortigão, R., \& Jong, M. d. (1885/1948). Holland 1883. Amsterdam: Jacob van Campen.

Ottens, E. (1975). Ik moet naar een kleinere woning omzien want mijn gezin wordt te groot. Amsterdam: Gemeentelijke Dienst Volkshuisvesting.

Pauwels, L. (Ed.). (2006). Visual Cultures of Science: Rethinking Representational Practices in Knowledge Building and Science Communication. Hanover (NH): Dartmouth College Press.

Payer, P. (2007). The Age of Noise : Early Reactions in Vienna, 1870-1914. Journal of urban history, 33(5), 773-793.

Picker, J. M. (2000). The Soundproof Study: Victorian Professionals, Work Space, and Urban Noise. Victorian studies : a quarterly journal of the humanities, arts and sciences, 42(3), 427-453.

Pinch, T., \& Bijsterveld, K. (2012). New Keys to the World of Sound. In T. Pinch \& K. Bijsterveld (Eds.), The Oxford Handbook of Sound Studies (pp. 3-35). New York: Oxford University Press.

Plasse, J. v. d., \& Verbei, W. (2005). Kroniek van de Nederlandse dagblad- en opiniepers. Amsterdam: Otto Cramwinckel.

Pleij, H., Gemert, L. v., \& Mathijsen, M. (2009). De verbeelding van de stad in de literatuur: Van de Middeleeuwen tot eind negentiende eeuw. In L. Lucassen \& W. Willems (Eds.), Waarom mensen in de stad willen wonen, 1200 - 2010 (pp. 124-151). Amsterdam: Bert Bakker.

Polak, H., \& Vlugt, W. d. (1936). Amsterdam die groote stad... : een bijdrage tot de kennis van het Amsterdamsche volksleven in de XIXe en XXe eeuw (2e dr. ed.). Amsterdam: Querido.

Potter, H. (1809). Wandelingen en Kleine Reizen door sommige gedeelten van het Vaderland, tweede deel Retrieved

from 
http://books.google.nl/books?id=gHJNAAAACAAJ\&printsec=frontcover\&source=gbs_ge_summary_r\&c $\mathrm{ad}=0 \# \mathrm{v}=$ onepage $\& \mathrm{q} \& \mathrm{f}=\mathrm{false}$

Presser, J. (1974). Autobiografische schets 1899-1919. Bergen N.H.: Eliance Pers.

Radkau, J. (1998). Das Zeitalter der Nervositat: Deutschland zwischen Bismarck und Hitler. München, Wien: Carl Hanser Verlag.

Radovac, L. (2011). The "War on Noise": Sound and Space in La Guardia's New York. American Quarterly, 63(3), 733-760.

Revill, G. (2000). Music and the politics of sound: nationalism, citizenship, and auditory space. Environment and Planning D: Society and Space, 18, 17.

Rieger, M. (2003). Musik im Zeitalter von Sound. Wie Hermann von Helmholtz eine neue Ära begründete. In T. Phleps \& R. v. Appen (Eds.), Pop Sounds. Klangtexturen in der Pop- und Rockmusik. Basics - Stories Tracks (pp. 183-196). Bielefeld: Transcript Verlag.

Ripley, C., Polo, M., \& Wrigglesworth, A. (Eds.). (2007). In the Place of Sound: Architecture / Music / Acoustics. Newcastle: Cambridge Scholars Publishing.

Rodrigues de Miranda, S. d. (1921). Amsterdam en zijne bevolking in de negentiende eeuw. Amsterdam: Scheltema en Holkema.

Roegholt, R. (1976). Amsterdam in de 20e eeuw, DI 1 (1919/1945). Utrecht: Het Spectrum.

Rooijen, J. v. (1995). De drooglegging van Amsterdam: Een onderzoek naar gedempt stadswater Retrieved September 15, 2010, from http://www.amsterdamsebinnenstad.nl/opendegrachten/docs/drooglegging.pdf?PHPSESSID=99ff1150bb8d90db9b99e522cd49f8c6

Rooy, P. d. (2006a). De geest van omverwerping 1851-1876. In R. Aerts, P. d. Rooy \& B. J. v. Benthem (Eds.), Geschiedenis van Amsterdam: hoofdstad in aanbouw 1813-1900. Amsterdam: SUN.

Rooy, P. d. (2006b). Een woelige wereldstad 1883-1893. In R. Aerts, P. d. Rooy \& B. J. v. Benthem (Eds.), Geschiedenis van Amsterdam: hoofdstad in aanbouw 1813-1900. Amsterdam: SUN.

Rooy, P. d. (2007a). De donkerte der tijden 1920 -1940. In P. d. Rooy (Ed.), Geschiedenis van Amsterdam: tweestrijd om de hoofdstad 1900-2000 (pp. 127-234). Amsterdam: SUN.

Rooy, P. d. (2007b). Het middelpunt van het vaderland 1901-1914. In P. d. Rooy, D. Bosscher, S. Bloemgarten \& M. Carasso-Kok (Eds.), Geschiedenis van Amsterdam: tweestrijd om de hoofdstad 1900-2000. Amsterdam: SUN.

Rooy, P. d. (2007c). Vaer wel, mijn Aemsterland Geschiedenis van Amsterdam: tweestrijd om de hoofdstad 1900-2000. Amsterdam: SUN.

Rooy, P. d., Bosscher, D., Bloemgarten, S., \& Carasso-Kok, M. (2007). Geschiedenis van Amsterdam: tweestrijd om de hoofdstad 1900-2000. Amsterdam: SUN.

Rosenfeld, S. (2011). On Being Heard: A Case for Paying Attention to the Historical Ear. The American historical review, 116(2), 316-335.

Ross, C. D. (2004). Sight, Sound, and Tactics in the American Civil War. In M. M. Smith (Ed.), Hearing History : a reader (pp. 267-278). Athens, Ga., etc.: University of Georgia Press.

Sajet, B., \& Fels, H. (1977). Een leven lang : Ben Sajet. Baarn: In den Toren.

Samuels, D. W., Meintjes, L., Ochoa, A. M., \& Porcello, T. (2010). Soundscapes: Toward a Sounded Anthropology. Annual Review of Anthropology, 39(1), 329-345. doi: doi:10.1146/annurev-anthro022510-132230

Sanders, E. (2011). Eerste Hulp Bij e-Onderzoek Retrieved from https://openaccess.leidenuniv.nl/bitstream/handle/1887/17774/Sanders;jsessionid=75E3F38251D6C0FD51DAE39C981D0C16?sequence $=6$

Saul, K. (1996a). "Kein Zeitalter seit Erschaffung der Welt hat so viel und so ungeheuerlichen Lärm gemacht..." - Lärmquellen, Lärmbekämpfung und Antilärmbewegung im Deutschen Kaiserreich. In G. Bayerl, N. Fuchsloch \& T. Meyer (Eds.), Umweltgeschichte - Methoden, Themen, Potentiale: Tagung des Hamburger Arbeitskreises für Umweltgeschichte, Hamburg 1994 (pp. 187-217). Münster: Waxmann.

Saul, K. (1996b). Wider die "Lärmpest". Lärmkritik und Lärmbekämpfung im Deutschen Kaiserreich. In D. Machule, O. Mischer \& A. Sywottek (Eds.), Macht Stadt krank? Vom Umgang mit Gesundheit und Krankheit (pp. 151-192). Hamburg: Dölling und Galitz Verlag. 
Schafer, R. M. (1977/1994). The Soundscape. Our Sonic Environment and the Tuning of the World. Rochester, Vermont: Destiny Books.

Schneider, M. (1943). De Nederlandse krant: van "Nieuwstydinghe" tot dagblad. Amsterdam: P.N. Van Kampen \& Zoon N.V.

Schot, J. (2003). The Contested Rise of a Modernist Technology Politics. In T. J. Misa, P. Brey \& A. Feenberg (Eds.), Modernity and Technology (pp. 257-278). Cambridge (MA): MIT Press.

Schwartz, H. (2011). Making Noise: From Babel to the Big Bang \& Beyond. New York: Zone Books.

Singleton, E. (1906). Holland as seen and described by famous writers. New York,.

Sluyser, M., \& Drees, W. (1957). Voordat ik het vergeet (2e dr. ed.). Amsterdam: Het Parool.

Smilor, R. W. (1977). Cacophony at 34th and 6th: The noise problem in America, 1900-1930. American Studies, 18(1). Retrieved from https://journals.ku.edu/index.php/amerstud/article/view/2297/2256

Smith, M. M. (2001). Listening to nineteenth-century America. Chapel Hill etc.: University of North Carolina Press.

Smith, M. M. (2007). Sensing the Past: Seeing, Hearing, Smelling, Tasting, and Touching in History. Berkely and Los Angeles: University of California Press.

Sterne, J. (2003). The audible past : cultural origins of sound reproduction. Durham etc.: Duke University Press.

Sterne, J. (2013). Soundscape, Landscape, Escape. In K. Bijsterveld (Ed.), Soundscapes of the Urban Past: Staged Sound as Mediated Cultural Heritage (pp. 181-193). Bielefeld: transcript Verlag.

Sterne, J. (Ed.). (2012). The Sound Studies Reader. London and New York: Routledge.

Stichting Democratie en Media. (n.d.). Het illegale Parool Retrieved March 1, 2013, from http://www.hetillegaleparool.nl/

Taverne, E., Dembski, S., Klerk, L. d., \& Ramakers, B. (2012). Greep op de stad: Nieuwe wendingen in het stadsonderzoek. In E. Taverne, L. d. Klerk, B. Ramakers \& S. Dembski (Eds.), Nederland stedenland: continuiteit en vernieuwing (pp. 9-22). Rotterdam: nai010 uitgevers.

Taylor, R., E. (2001). Death of neurasthenia and its psychological reincarnation: A study of neurasthenia at the National Hospital for the Relief and Cure of the Paralysed and Epileptic, Queen Square, London, 1870-1932. The British Journal of Psychiatry, 179, 7.

Thompson, E. (2002). The soundscape of modernity : architectural acoustics and the culture of listening in America, 1900-1933. Cambridge, MA etc.: MIT Press.

Thompson, E. P. (1967). Time, Work-Discipline, and Industrial Capitalism. Past \& Present, 38(December), 5697.

Thuillier, G. (1977). Pour une histoire du quotidien au XIXe siècle en Nivernais. Paris: Mouton.

Tijn, T. v. (1974a). Berusting en beroering: aspecten van Amsterdams sociale geschiedenis in de negentiende eeuw. Ons Amsterdam / maandblad van de Gemeentelijke Commissie Heemkennis, 26, 9.

Tijn, T. v. (1974b). Geschiedenis van de Amsterdamse diamanthandel en -nijverheid, 1845-1897. Tijdschrift voor Geschiedenis, 87, 16-70; 160-201.

Timmerman, A. W. (1938). Tim's herinneringen. Amsterdam: Paris.

Tjaden, M. E. H. (1929). De kleine electro-motor als vrijbuiter ingetoomd. Bouwbedrijf(10), 190-191.

Toyka-Seid, M. (2005). Noise Abatement and the Search for Quiet Space in the Modern City. In D. Schott, B. Luckin \& G. Massard-Guilbaud (Eds.), Resources of the city : contributions to an environmental history of modern Europe (pp. 215-229). Aldershot: Ashgate.

Trommler, F. (2004). Conducting Music, Conducting War: Nazi Germany as an Acoustic Experience. In N. M. Alter \& L. Koepnick (Eds.), Sound Matters: Essays on the Acoustics of Modern German Culture (pp. 6576). New York, Oxford: Berghahn Books.

Verstrate, L. (2012). Spelen op het Afrikaanderplein. Honderd jaar stadskinderen in de openbare ruimte. In E. Taverne, L. d. Klerk, B. Ramakers \& S. Dembski (Eds.), Nederland stedenland: continuiteit en vernieuwing (pp. 165-177). Rotterdam: nai010 uitgevers.

Verwey, G. (1994). 's Levens avontuur : een autobiografie. Amsterdam: De Bataafsche Leeuw.

Vincent, D. (2000). The Rise of Mass Literacy: Reading and Writing in Modern Europe. Cambridge: Polity Press. 
Voormolen, S. (2012, 10/11/2012). Letters van geluid, Wetenschapsbijlage, NRC Handelsblad, p. 7.

Vries, B. M. A. d. (1986). Electoraat en elite : sociale structuur en sociale mobiliteit in Amsterdam, 18501895. Amsterdam [etc.]: De Bataafsche Leeuw.

VVV. (2011). I Amsterdam Retrieved February 8, 2011, from http://www.iamsterdam.com/nl/placestogo/amsterdam-centraal-station/6d5d80b4-40b1-4bed-9a8e-8b40d0b10338\#

Wagenaar, M. (1981). Kantoren, hotels en warenhuizen. Functie-veranderingen in de Amsterdamse binnenstad 1870-1940. Ons Amsterdam / maandblad van de Gemeentelijke Commissie Heemkennis, 33, 194-199.

Wagenaar, M. (1984). Van 'gemengde' naar 'gelede' wijken: Amsterdamse stadsuitbreidingen in het laatste kwart van de negentiende eeuw. In M. Jonker, L. Noordegraaf \& M. Wagenaar (Eds.), Van stadskern tot stadsgewest : stedebouwkundige geschiedenis van Amsterdam (pp. 157-182). Amsterdam: Verloren.

Wagenaar, M. (1990). Amsterdam 1876-1914 : economisch herstel, ruimtelijke expansie en de veranderende ordening van het stedelijk grondgebruik. Amsterdam: Historisch Seminarium van de Universiteit van Amsterdam.

Wagenaar, M. (1998). Stedebouw en burgerlijke vrijheid : de contrasterende carriëres van zes Europese hoofdsteden. Bussum: Thoth.

Wijfjes, H. (1994). Het radiotijdperk, 1919-1960. In H. Wijfjes \& E. Smulders (Eds.), Omroep in Nederland: vijfenzeventig jaar medium en maatschappij, 1919-1994 (pp. 40-75). Zwolle: Waanders.

Wolf, M. (2007). An Anglo-American Newspaper in Holland: Form and Style of De Telegraaf (1893-1940). In M. Broersma (Ed.), Form and Style in Journalism: European Newspapers and the Representation of News 1880-2005 (pp. 81-94). Leuven: Peeters.

Wood, C. W., \& Baarslag, C. (1878/2002). Door Nederland. Rijswijk: Elmar.

Woud, A. v. d. (2010). Koninkrijk vol sloppen : achterbuurten en vuil in de negentiende eeuw. Amsterdam: Bert Bakker.

Wouters, K. C. A. T. M. (1999). Ongewenschte muziek. Den Haag: Sdu Uitgevers.

Yaron, J. (2011). 'Silenced Power': Warfare Technology and the Changing Role of Sounds in TwentiethCentury Europe. Zeithistorische Forschungen/Studies in Contemporary History, 8(2). Retrieved from http://www.zeithistorische-forschungen.de/16126041-Jean-2-2011>

Zadoks, S. (1899). Geschiedenis der Amsterdamsche concessies. Amsterdam: Holkema en Warendorf. 


\title{
The sound of yesterday: Why Amsterdam wasn't particularly silent in the past
}

\author{
Summary ${ }^{179}$
}

This dissertation deals with sound as part of everyday life in the city by zooming in on the case of Amsterdam. The sounds covered in the argument presented here may have been produced deliberately or not; they may have received attention or were largely ignored; and they perhaps triggered uproar or fierce debates, if not concrete actions. My motivation for this focus on urban sound in all its diversity is the following paradoxical situation: although the common view holds that modern cities have increasingly grown noisier due to the expansion, industrialization and technologization of society, (Hendy, 2013, pp. xii-xiii) we still know very little about past sounds in cities or the role of sounds and noise in the everyday life of city residents. At the same time, the very notion that cities have grown noisier all the time assumes a comparative basis in the past. The ongoing emergence of new sources of sound, as well as our limited memory of vanished sources of sound, may seem to justify the claim that life used to be quieter in the old days. As this dissertation will demonstrate, however, it is not enough to pay attention exclusively to sources of sound in order to make claims about the appreciation of sound, be it in the past or the present.

The roots of this study of the urban sounds of Amsterdam can be found in the renewed attention for the role of sounds in our everyday surroundings since the 1970s, when composer and environmental activist Raymond Murray Schafer introduced the concept of 'soundscape'. As such this dissertation belongs to the interdisciplinary field of Sound Studies, which investigates the production and the consumption of music, sound, noise and silence, and the interrelated changes in the course of time and in divergent societies.

My argument in this dissertation starts from a definition of the concept of 'soundscape', which refers both to a world outside of us - all the sounds that permanently surround us - and to the ways in which human beings actively perceive that outside world and give meaning to it. In other words, this study seeks to map the interconnection between the urban sounds produced in a particular era and the meaning attributed to these sounds in daily life. Thereby I have also tried to identify the mechanisms that explain why some sounds receive attention and are potentially declared undesirable (or characterized as noise), while other, seemingly similar sounds are ignored.

\footnotetext{
${ }^{179}$ Engelse vertaling: Ton Brouwers.
} 
To gain insight into the ways and degree in which sounds have played a role in daily life in Amsterdam, I analyzed texts belonging to various nonfiction genres in which the authors address the sounds of this city. Specifically I selected relevant parts from newspaper articles, municipal reports, letters to the editor, travel accounts, published memoirs and unpublished diaries that somehow touch on the city's everyday functioning. Because not all sounds produced in the city are covered in these texts, I also used secondary literature on activities and material aspects of everyday life in Amsterdam. This made it possible to trace which sounds residents or visitors of the city could have heard.

This study concentrates on three historical periods of everyday life in Amsterdam of which it is known that many changes occurred with respect to sound: the periods 1875-1895, 1918-1940 and 1940-1945. The final quarter of the nineteenth century was a period in which Amsterdam was marked by rapid population growth, industrialization and technologization; in many ways its urban sounds will have been those of a decidedly 'modern' city. Although initially this trend of expansion and development was sustained during the interwar period (the 1920s and 1930s), the role of sound and noise in discussions about urban life grew much larger at this time. Finally, the Second World War also presents an interesting case-study because the city suddenly had to deal with a host of altogether new sounds, radically altered meanings of sounds as well as the disappearance of familiar sounds.

Another factor in selecting these three periods pertains to the analytical framework applied, which highlights three angles or perspectives: the ecology of sound, the semiotics of sound and the politics of sound. I provide a systematic analysis of each period based on these analytical categories, but I also use my discussion of each of the periods to develop one of these categories in more detail. This tripartite framework allows us to gain a better understanding of the complex and changeable relationship between sound, the meanings of sound and interventions in sound. As regards the sounds of people's everyday living environment, which I refer to as the 'ecology of sound', the focus has been on which contemporary urban sounds were in fact mentioned in texts from the period at hand, which other sources of sound were present as well, and which changes occurred in the nature, number and volume of those sounds. The second dimension of my analytical frame, the 'semiotics of sound', emphasizes the role of the meanings of sound by addressing how urban sounds were discussed and which meanings were attached to it in contemporary texts. The third perspective, the 'politics of sound', focuses on sound as an element of political and social issues. This focus comprises questions about the role of sounds aimed at attracting attention to particular views or situations in some period, or whether particular interventions were proposed and/or implemented to fight the nuisance of urban sounds. Finally, based on the answers to the abovementioned questions and the contemporary discourse about sound - that is, the ways in which sounds and their meanings were described, represented and interpreted - I discuss the interconnection of the sounds produced in the 
period at hand, the sounds that received attention or were ignored, and the sounds that triggered particular interventions.

Although this dissertation belongs to the field of Sound Studies, its concerns also cover 'the livability of cities', a theme which receives increasing attention within the field of Urban History. This theme is also center-stage in so-called 'Urban Labs', which in their research of historical and future cities cut across disciplinary boundaries and existing professional practices to pay attention to a large variety of aspects of urban life, including sensory experiences. My study about sound as part of everyday urban life may contribute to this varied work by serving as a supplement to the primarily visual information on urban materiality, while also revealing how auditory 'materiality' has been largely determined by and negotiated in social and cultural processes.

In the period 1875-1895, my first case-study, Amsterdam faced a strong growth of its population, of trade and business, and of new modes of industry, some of which increasingly embraced production processes powered by steam engines. This beefed up business activity also meant more traffic circulation, that is, more pedestrians, handcarts and horse-drawn trucks, trams and carriages on the streets, and occasionally one would even see - and hear - a steam ship on one of the city's waterways. Initially, most of this urban activity took place in what today is the inner city, the area confined by the outer circular canal (the singelgracht). This is also where that largest stock of houses was found, even though this confined area could barely accommodate the growing number of urban residents. Large groups of residents lived squeezed together in one-room apartments, which sometimes also doubled as work space. Where this was not the case, people needed to have a job nearby, in a shop or workplace they could easily reach afoot, for there were no bicycles yet, and commuting by tram was too expensive for the average worker.

Against the backdrop of all sorts of bustling activity and the rather miserable living conditions of a substantial share of the local population, texts from this period devote much attention to the human voice, as well as to bells and music, while there is much less attention for sounds of traffic and hardly any attention for the sounds of handiwork and industrial activities. The thinking and writing about sound still reflected an older notion of sound: as a phenomenon that started from a fundamental contradiction between music and all other sounds. This is why musical terms played a large role in the jargon, while many of today's words for sounds had another meaning at that time. If words like 'noise' (lawaai) and 'din' (herrie) could refer to much sound, they were used in particular to connote a lack of order, utterances of protest, divergent opinions or claptrap. The word 'sound' was often used to refer to a singer's voice: he or she produced a 'nice sound'. And where we would use 'noise' (lawaai), in the years 1875-1895 one used words such as 'buzz' (gedruisch) and 'roar' (geraas).

The thinking about sound in terms of music and non-music seems to imply that at the time music represented some sort of ideal sound and that all other sounds represented a lesser if not banal quality. In this logic, one is also more likely to gear atten- 
tion to voices and musical instruments, the sources of the sounds admired or valued. In this context complaints about less desirable sounds also focused on this type of sources including, for instance, talking voices and carillon music, which kept foreign visitors from sleeping and made them complain about the unmusical ears and voices of the Dutch. Residents of Amsterdam, in turn, mostly complained about the voices and music of the 'lesser people' or 'mob', a segment of the population that ought to be 'compliant and meek'. When they still let themselves be heard - for instance, as 'rough blokes, howling vendors and shouting street urchins' - this was an erosion of the established order and its civilization. This also makes it understandable that the noise of factories was hardly seen as a problem. In fact, it generated little public attention, unlike the 'reprehensible tunes' of the workers. It is relevant here that the gap between working class and bourgeoisie was still substantial during this era. The views and opinions voiced in the available texts were largely those of educated residents or visitors of course, as working-class residents were much less likely to write books or letters to newspapers.

Compared to the late nineteenth century, the discourse on sound and the city took on a quite different character in the interwar period. This period is the focus of the second case-study. In the 1920s and 1930s, sound was increasingly approached from a physical and/or technological angle, as marked by vibration and a certain intensity, as a phenomenon working on the human ear and 'nerves'. During this time, engineers developed several methods and units of measuring sound, including the well-known decibel. In contrast to the late-nineteenth-century discourse on sound, the words 'sound', 'din' and 'street noise' (straatrumoer) were now mostly used in ways familiar to us today.

There are several reasons to assume that the sounds of urban traffic have changed significantly since the late nineteenth century. By the 1930s, many streets, for one, were paved with asphalt and wheels came with pneumatic tires. This partly suppressed the noise of moving vehicles. At the same time, however, the horse-drawn trams, cars and carriages had been replaced by electric trams, trucks and cars, while in absolute terms the number of vehicles had significantly gone up. Because all these sources of sound, taken together, contributed to the masking of separate sounds, and much traffic also moved along at greater speeds, many vehicles needed to signal their presence through bells and honking. Also, horses and carriages could still be seen and heard in the city, as was true of handcarts and hawkers. The large pack of bicyclists was new as well by the 1930s; together with the expansion of the tram network, they played a major role in commuter traffic. The intensity of traffic and the much wider spectrum of speeds called for another conduct in traffic and other uses of streets. Way into the 1930s, this process of change was accompanied by much honking and sounding of bells, as well as by much discussion about the need for and meaning and nuisance of such deliberately loud sounds. 
What is more, in this period living and working increasingly took place in separate urban quarters. Factories and businesses no longer had to be situated at walking distance, and the city's expansion through annexation of surrounding municipalities gave rise to a band of new, partly suburban neighborhoods around the old inner city. In these new city neighborhoods, local residents, who used to live in the inner city's cramped communities and deplorable houses, lived in more spacious homes and a relatively quieter environment. Furthermore, the rise of prosperity and regulation of labor conditions resulted in an increase of leisure.

In such silence and peacefulness potential sounds were more intrusive, causing noise by neighbors to be a source of irritation much easier. Furthermore, the strict class distinctions gradually receded to the background in favor of a much more diffuse yet also harder to fathom social structure. At this time, popular media such as newspapers and radio frequently reported on the bright and shady sides of America's titillating metropolitan life. In this context undesirable sounds in Amsterdam were no longer connected to the 'mob', but, after the American model, to the 'masses', whose members - through their 'inborn rudeness' - let themselves get carried away by jazz music, improper dancing, cinema and other 'cheap' entertainment. They were perceived, in other words, as loud and noisy people, who were incapable of responsibly handling their radio set, gramophone, motorcycle or car horn.

The Second World War, the third period under study here, announced itself in Amsterdam by the nightly sounds of aircraft and anti-aircraft guns. Moreover, for a large number of residents this noise, together with the air-raid sirens, constituted the most direct experience of war violence in the days prior to the country's surrender. When by 16 May 1940 daily life seemed more or less restored, people were struck by the relative silence in the city; unlike in the prewar period, the noise of cars and buses was now largely absent.

The outbreak of the war had caused abrupt changes in the meaning of particular sounds - the noise of aircraft, for instance, turned into a warning for a potentially lifethreatening situation - but the Dutch surrender again gave rise to new meanings. Suddenly, for example, the anti-aircraft guns were aimed at 'friendly forces' rather than the 'enemy'. This caused people to listen differently, even if the noise itself or the dangers involved may have been quite similar.

The sounds of war activities also gave rise to new expressions: the anti-aircraft guns 'barked' (blaft) or 'blared' (tettert) and the sirens 'shrieked' (loeien) and 'wailed' (huilen). The discourse about urban sounds changed as abruptly as the meaning of particular sounds, even if there was no change in the physical nature of the sound or the jargon used to describe it. The noises of traffic, which during the interwar era gave rise to much discussion and complaining, were now dearly missed as a sin of better days. Likewise, neighborly noise was no longer reason for complaining. It rather served as a reassuring sign of the neighbors' presence, or, in a situation where neighbors willingly or unwillingly posed a risk, as a major source of information. As the war 
progressed, the silence in the city became a sign of the involuntary leaving of many Jewish residents and the uncertain fate awaiting them. Aside from the loud noises of aircraft, anti-aircraft guns, sirens and shooting, then, silence evolved into a quite intense 'sound' of war as well.

Adults, sometimes much to their surprise, proved capable of adapting to the sounds of war swiftly, but for youngsters and children the powerful noise of antiaircraft guns, explosions and sirens continued to be frightening. Most city residents did not welcome the German presence, and this also applied to the sounds accompanied with it. As a result, these were either ignored in the discourse or characterized through words such as shouting, yelling or clamor. Apart from this form of 'politics of sound', whereby normative language was used to describe a situation or conduct one loathed, both sides deployed music to practice politics during the war. While parties linked to the Germans organized musical performances and parades in town, for many local residents the national anthem and other music associated with Dutch identity became a sign of resistance and self-affirmation.

The three historical case-studies about the sounds of Amsterdam reveal that we cannot well understand the influence of changes on everyday urban life in the past from the perspective of the soundscape we inhabit today. In 'bridging' our distance to historical soundscapes and their role in everyday life, the analytical frame applied in this study serves as a productive tool. It throws more light on the specific historical relations between the material aspects of the soundscape (ecology of sound), the interventions in sound (politics of sound) and the meanings involved (semiotics of sound). The meaning attached to silence in the 1920s and 1930s, for example, changed in the subsequent war, which makes it understandable that the noise of car traffic, which used to give rise to lots of complaining, was desperately missed by residents during the war. Similarly, the increasing complaints about neighborly noise during the interwar period did not logically follow from a growing population density in the city, but should be seen in the light of the fact that for the first time a large segment of the local population lived in more spacious, quiet suburban neighborhoods.

A comparison of the three cases reveals that it would be wrong to assume that population growth, industrialization and technologization will automatically lead to 'more' sound, and hence to an increase of complaints about sound. Moreover, the complaints voiced do not need to be tied directly to the sounds produced by more people, machines and workplaces. Despite the growing industrialization and technologization of Amsterdam during the years 1875-1895 and the interwar period, the increased noise of machines and industry failed to generate much attention as of yet.

If we compare the results of this study with the role of sounds and noise in our own era, it strikes one that today complaints about noise tend to be no longer connected to a moral sense of the erosion of order and decency by society's marginalized forces or to overstimulation of the urban residents' nervous system resulting from irresponsible behavior by the immoderate man in the crowd; rather, they are linked to 
the exposure to detrimental influences that make people ill and are costly to boot. Such comparative approach to complaints about noise - covering, in this instance, the late nineteenth century, the interwar period and our own time - is interesting because it underscores that in each period a limited number of sounds is associated with largely abstract and uncontrollable threats and dangers. In the Second World War, 'silence' proved to have such function, symbolizing a threat or sense of danger because of the absence of familiar urban sounds or because the uncertainty of the moment was thus stressed.

This dissertation has shown that in the course of nearly a century and a half much has changed when it comes to the sounds of Amsterdam, but that it is not possible to understand these changes simply in terms of more or less urban silence, or more or less noise. Every era has sounds of its own, and words of its own to describe these sounds, as well as its own ways of expressing complaints about noise or articulating views on silence. Silence may connote an oppressive sound of war but also a melancholy sense of loss for a city that used to be lively and vigorous. For this reason, claims that cities grow ever noisier or that their sounds get 'worse' all the time need to be largely understood as a rhetorical strategy for expressing discontent with the present. 



\section{Curriculum Vitae}

Annelies Jacobs (Beek (L), 1955) studeerde Bouwkunde aan de Technische Universiteit Eindhoven (TUE) en Cultuurwetenschappen aan de Universiteit Maastricht (UM). Ze studeerde in 1981 af aan de TUE in de discipline Architectuur- en Stedenbouw en in 2006 aan de UM binnen de specialisatie Maatschappijwetenschappen en Techniek. In de periode 1984 - 2001 werkte ze achtereenvolgens als business- en informatie analist, secretaris, en beleidsmedewerker strategie bij het Algemeen Burgerlijk Pensioenfonds en voltooide in dat kader professionele opleidingen op het vlak van informatie- en communicatietechnologie, bedrijfskunde en sociale zekerheid.

Tijdens de daaropvolgende studie aan de UM vervulde Annelies diverse studentassistentschappen. In het kader van het NWO project Sound Technologies \& Cultural Practices deed ze etnografisch veldwerk; bij gelegenheid van het zesde lustrum van de UM in januari 2006 maakte ze een tentoonstelling over de Rijksmonumenten van de UM en verder was ze als student assistent betrokken bij Sound Souvenirs, de Maastrichtse nominatie voor de Academische Jaarprijs 2005/2006.

In 2006 kreeg ze een 'Talent Development Grant' van de Faculteit der Cultuur- en Maatschappijwetenschappen (FASoS, UM) ten behoeve van de voorbereiding van het onderzoeksvoorstel Soundscapes of the Urban Past: Staged Sound as Mediated Cultural Heritage. In de periode 2008 tot en met 2013 was ze als PhD onderzoeker werkzaam binnen het gelijknamige en door NWO gefinancierde project. In dat kader verwierf ze tevens de Basis Kwalificatie Universitair Onderwijs en nam ze deel aan de trainingsprogramma's van de FASoS Graduate School en de Nederlandse Onderzoekschool voor Wetenschap, Technologie en Moderne Cultuur (WTMC).

Annelies is auteur van 'Oorlogsgeluid in de stad en stadsgeluid in oorlogstijd: klank en betekenis' in het tijdschrift Stadsgeschiedenis, 2012(1); 'The Silence of Amsterdam before and during World War II: Ecology, Semiotics and Politics of Urban Sound', in D. Morat (Ed.), Sounds of Modern History. Auditory Cultures in 19th and 20th Century Europe (2014) en van 'Het geluid van glas: Een ongehoorde dimensie in de architectuur' in Mosaiek: Interdisciplinair Cultuurhistorisch Tijdschrift, 2005(2). Daarnaast is ze coauteur van een of meer hoofdstukken in de volgende publicaties: Soundscapes of the Urban Past: Staged Sound as Mediated Cultural Heritage (2013); Contemporary Culture: New Directions in Arts \& Humanities Research (2013); Sound des Jahrhunderts (2013); Sound Souvenirs: Audio Technologies, Memory and Cultural Practices, (2009). 